\title{
COMPARAÇÃO ENTRE O DESENVOLVIMENTO DE CANA CRUA E CANA queImada em doIS CIClos de CRESCIMENTO
}

\author{
IVAN ANDRÉ ALVAREZ \\ Engenheiro Aǵrônomo
}

Orientador: Prof. Dr. PAULO R. C. CASTRO

Dissertação apresentada à Escola Superior de Agricultura "Luiz de Queiroz", Universidade de São Paulo, para obtenção do título de Mestre em Agronomia, Área de Concentração: Fisiologia e Bioquímica de Plantas.

PIRACICABA

Estado de São Paulo - Brasil

Julho - 1998 
Dados Internacionais de Catalogação na Publicação (CIP) DIVISĀO DE BIBLIOTECA E DOCUMENTAÇĀO - Campus "Luiz de Queiroz"/USP

Alvarez, Ivan André

Comparação entre o desenvolvimento de cana crua e cana queimada em dois ciclos de crescimento / Ivan André Alvarez. - - Piracicaba, 1998.

$120 \mathrm{p}$.

Dissertação (mestrado) - Escola Superior de Agricultura Luiz de Queiroz, 1998. Bibliografia.

1. Cana-de-açucar 2. Colheita 3. Ecofisiologia vegetal 4. Efeito da queimada 5. Impacto ambiental I. Título 
"A CIÊNCIA SERÁ SEMPRE UMA BUSCA, JAMAIS UM DESCOBRIMENTO REAL. É UMA VTAGEM, NUNCA UMA CHEGADA."

Karl Popper - Filósofo austríaco 
A meus pais

Marina e Jacob

pela liberdade e pelo apoio incondicional

Dedico 


\section{Agradecimentos}

Ao Prof. Dr. Paulo R. C. Castro, pela orientação e amizade;

À Prof. Dra. Eunice Melotto - Chody, pelo apoio e amizade;

À Prof. Marina André de Alvarez, pela revisão criteriosa;

À Prof. Maria Cristina Stolf Nogueira, pela orientação nas análises estatísticas;

Ao Prof. Dr. Marcos Silveira Bernardes, pela revisão crítica e sugestões.

Ao Conselho Nacional de Desenvolvimento Científico e Tecnológico (CNPq), pela concessão de bolsa;

À Usina Santa Elisa pela cessão de área experimental;

Aos funcionários da Fazenda Barra do Agudo pela prestimosa colaboração na coleta de dados;

À Du Pont pelo apoio financeiro; 
À Prof. Inês Cristina Batista Fonseca pelas sugestóes na análise estatística;

Ao Prof. Dr. Ricardo Ferraz de Oliveira, pelo apoio técnico;

Aos funcionários do Departamento de Botânica, pela atenção dispensada;

Aos amigos Alexandre e Lucieta pelo apoio na confeç̧ão final da tese e pela amizade fraterna.

Aos amigos Edson, Márcia, Vanderlei e Yolanda, pelo carinho e constante incentivo;

Ao meu irmão Alexandre, pela contribuição na fase experimental do trabalho.

Enfim, a todos que contribuíram na minha formação e que, de alguma maneira, estiveram presentes em algum momento desse trabalho. 


\section{SUMÁRIO}

Página

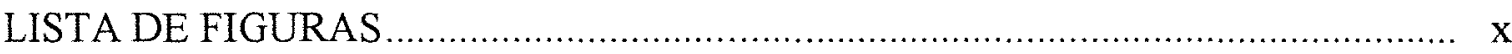

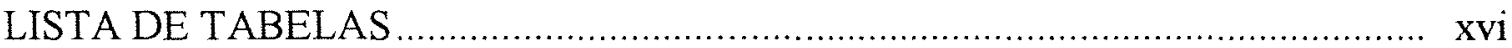

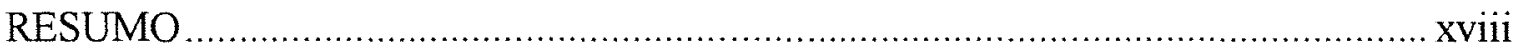

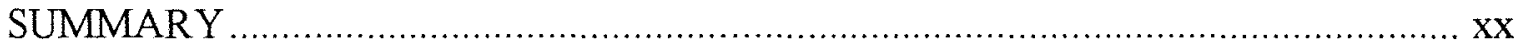

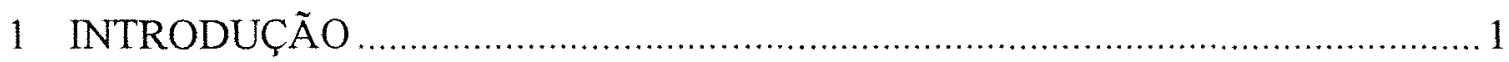

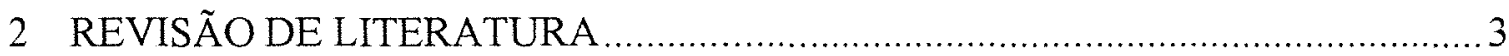

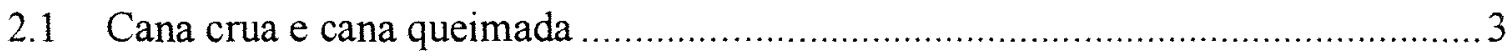

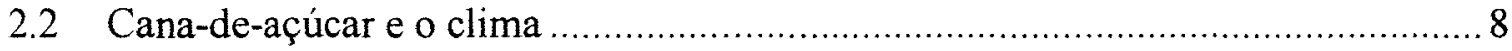

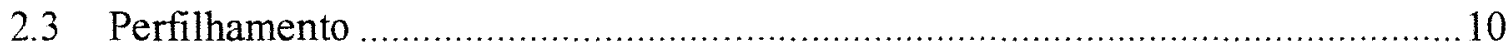

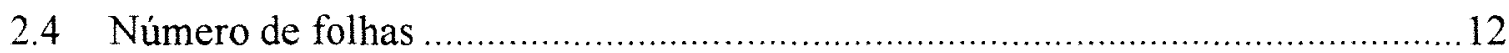

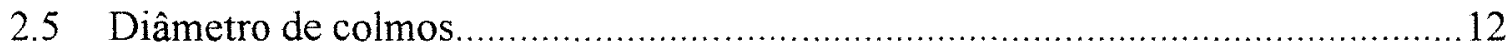

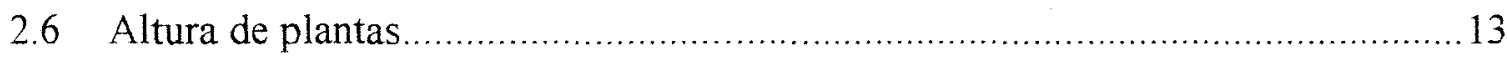

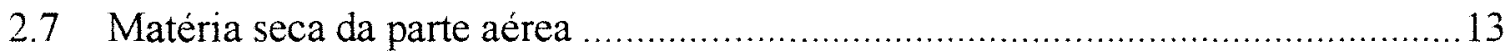

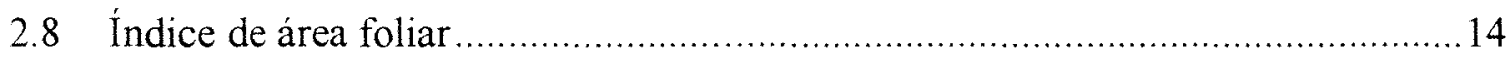

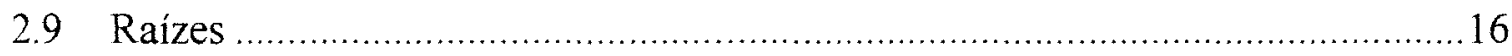

3 MATERIAL E MÉTODOS .................................................................. 19

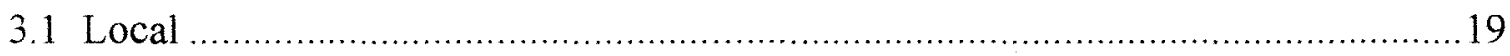

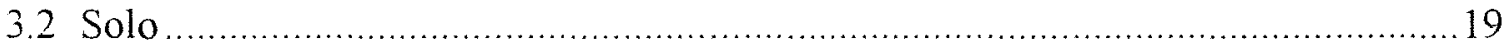


Página

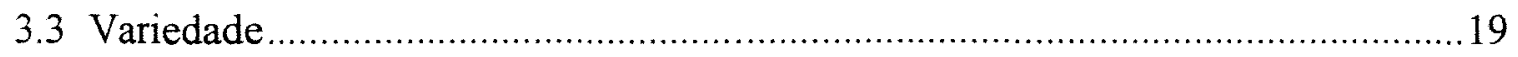

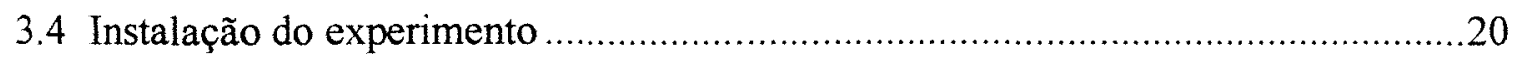

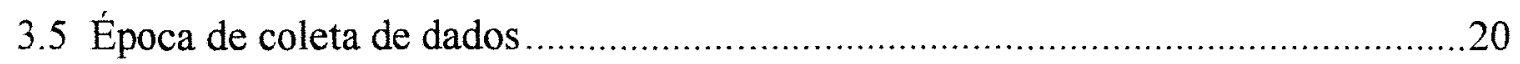

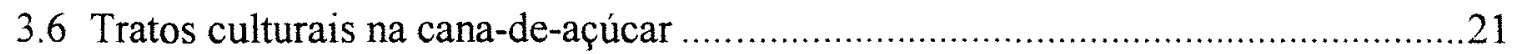

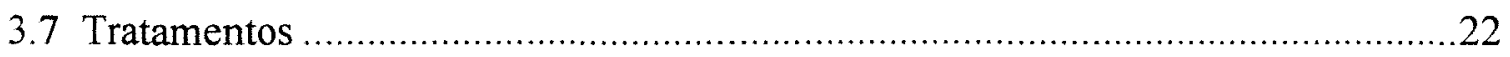

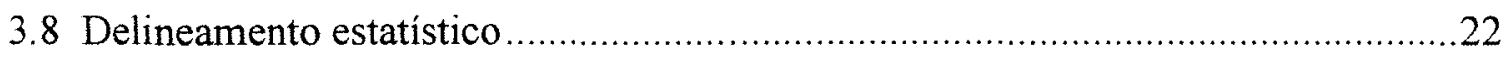

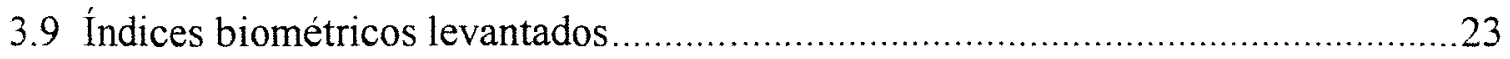

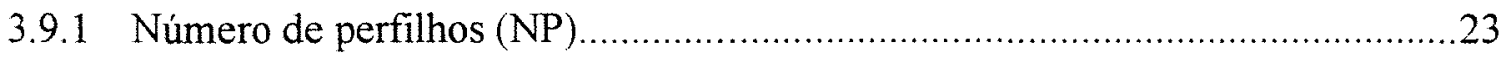

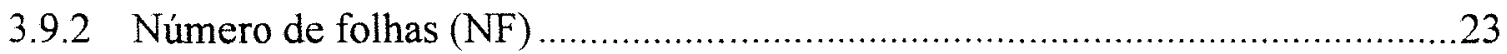

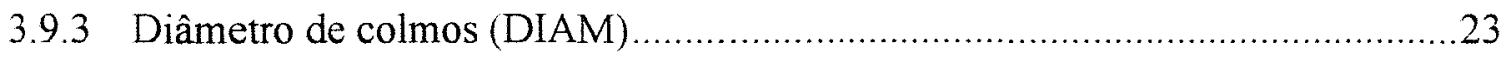

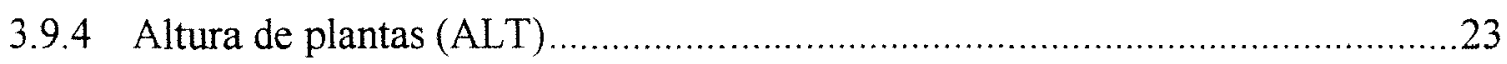

3.9.5 Matéria seca de colmos, folhas e parte aérea (MSC, MSF e MSPA) ……........23

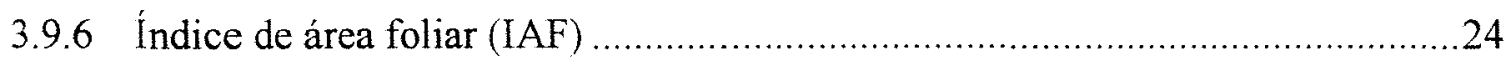

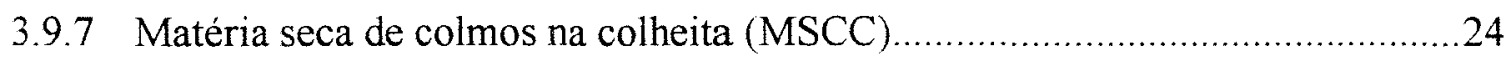

3.9.8 Matéria seca de raízes e perfil de raízes (MSR e PR) ……………................24

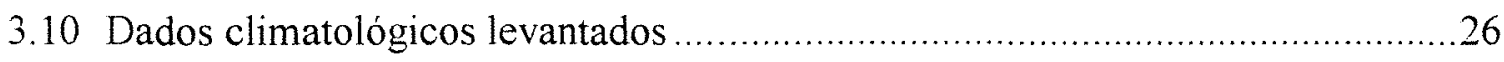

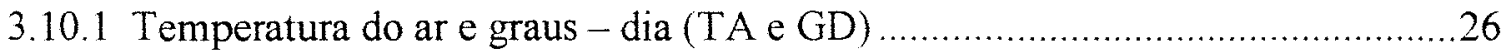

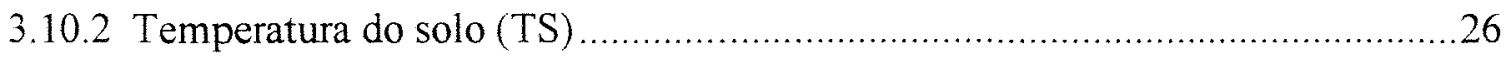

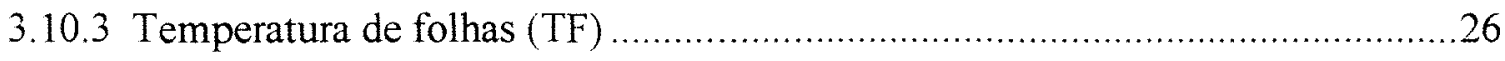

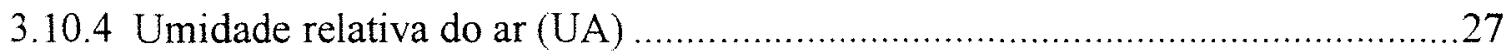

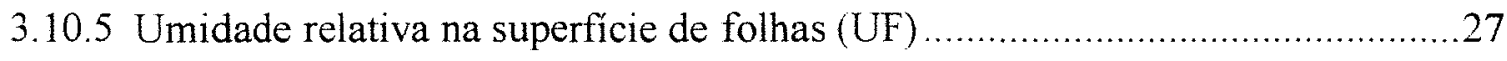

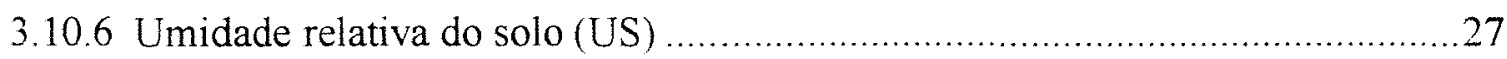

3.11 Levantamento de população de cigarrinhas (Mahanarva fimbriolata) ….............27 
Página

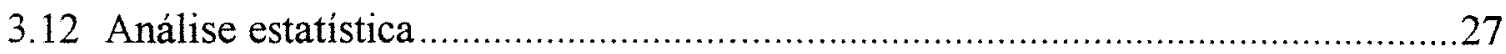

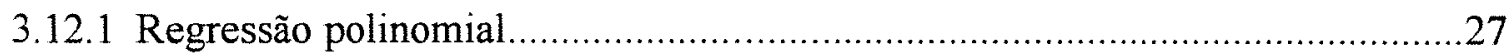

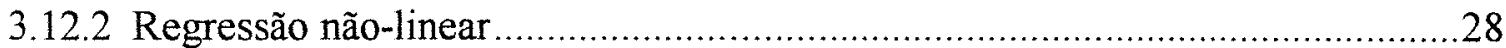

3.12.3 Comparação entre cana crua e cana queimada ..........................................28

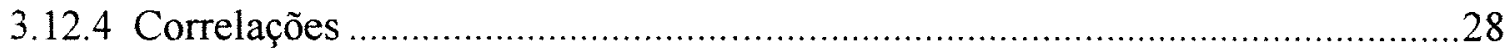

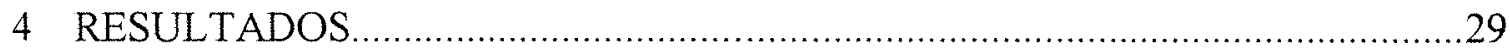

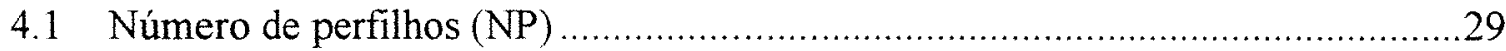

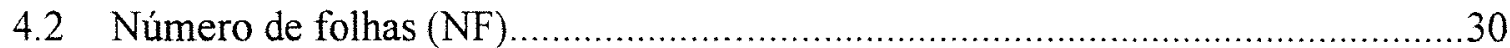

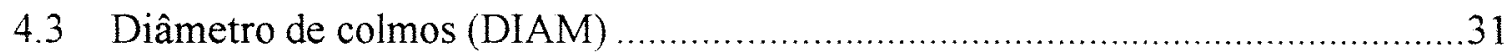

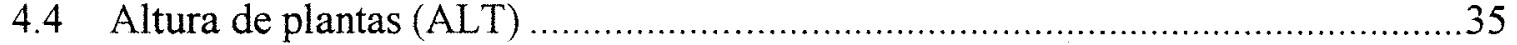

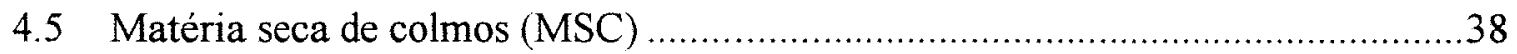

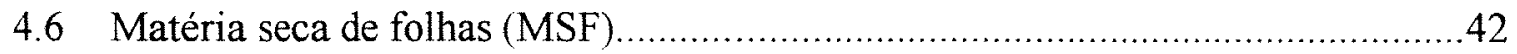

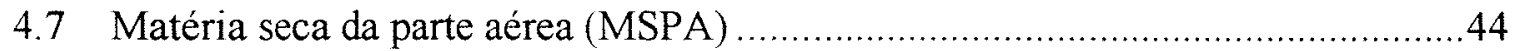

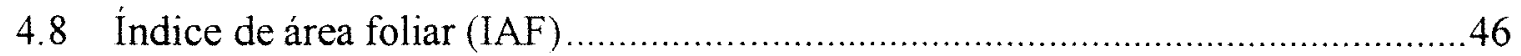

4.9 Matéria seca de colmos na colheita (MSCC) ...............................................48

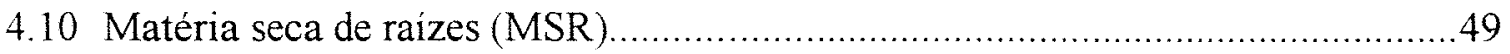

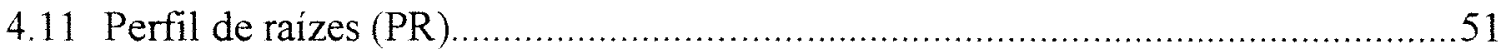

4.12 Levantamento de população de cigarrinhas (Mahanarva fimbriolata) ................55

4.13 Condições ambientais frente aos índices biométricos ..................................56

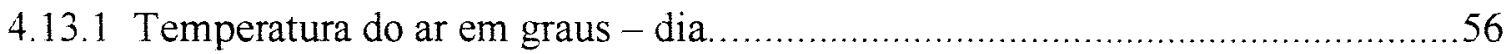

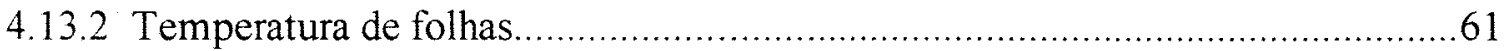

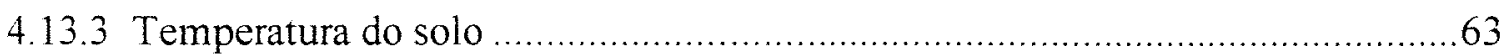


Página

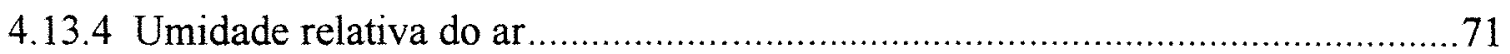

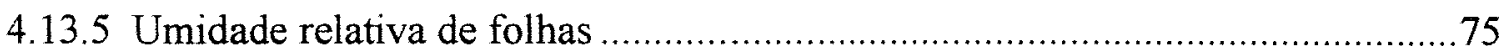

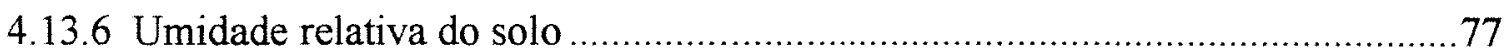

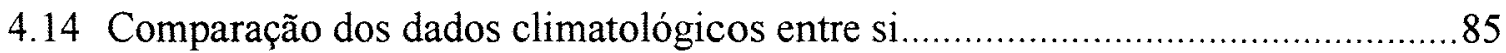

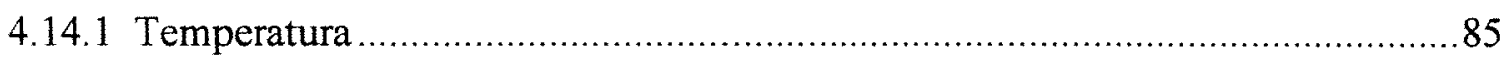

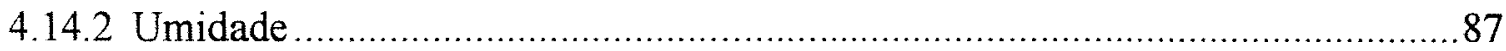

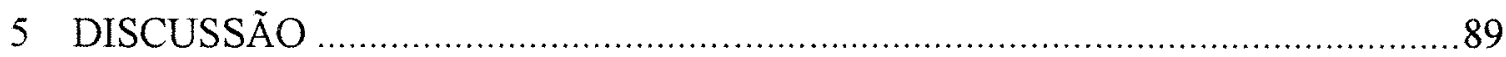

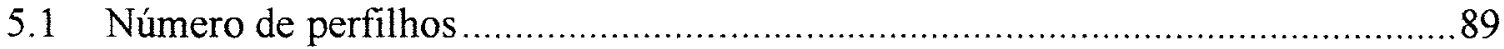

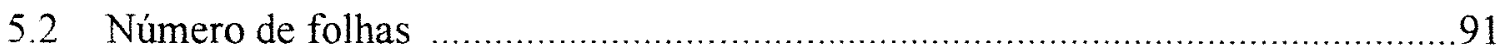

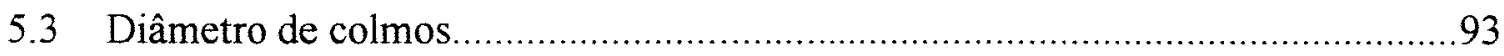

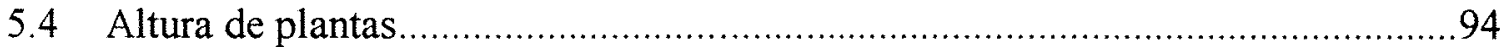

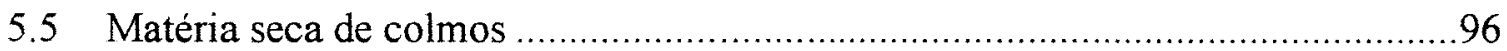

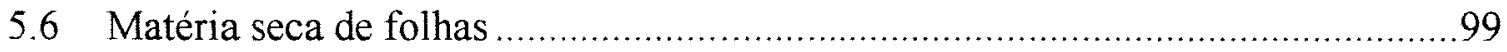

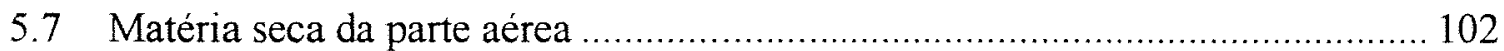

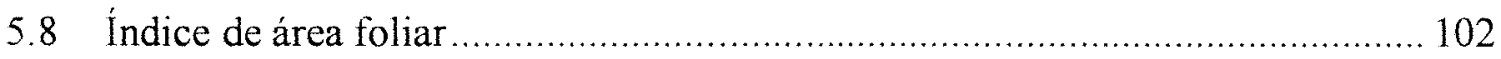

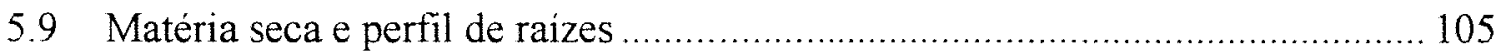

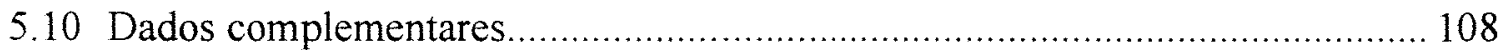

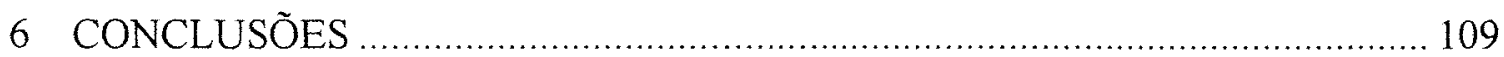

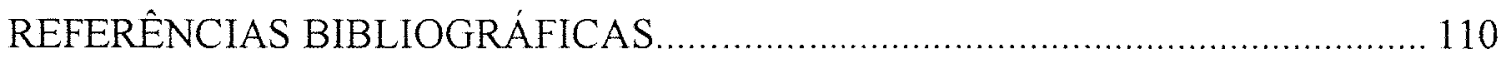




\section{LISTA DE FIGURAS}

Figura $N^{0}$

Página

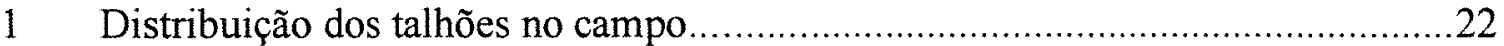

2 Desenho esquemático das regiões amostradas para a avaliação radicular ............25

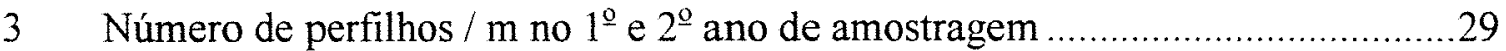

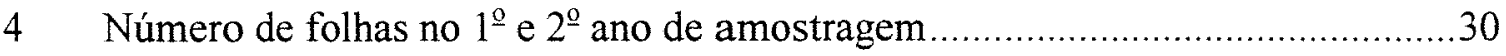

5 Diâmetro de colmos (mm) no $1^{\underline{0}}$ e $2^{\mathrm{o}}$ ano de amostragem ...................................32

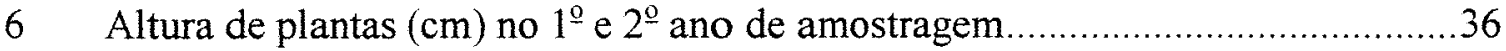

7 Matéria seca de colmos $\left(\mathrm{g} \cdot \mathrm{m}^{-2}\right)$ no $1^{\circ}$ e $2^{\circ}$ ano de amostragem.............................39

8 Matéria seca de folhas $\left(\mathrm{g} \cdot \mathrm{m}^{-2}\right)$ no $1^{\mathrm{o}}$ e $2^{\mathrm{O}}$ ano de amostragem.............................43

9 Composição da matéria seca da parte aérea, em porcentagem, para cana crua e

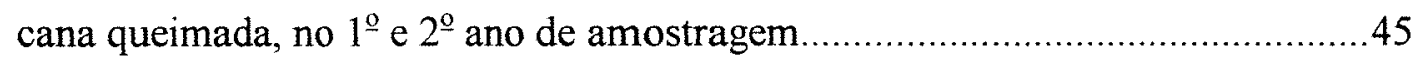

10 Índice de área foliar $\left(\mathrm{dm}^{2} \cdot \mathrm{dm}^{-2}\right)$ no $1^{\circ} \mathrm{e} 2^{\mathrm{o}}$ ano de amostragem .........................47

11 Matéria seca de colmos na colheita $\left(\mathrm{g} \cdot \mathrm{m}^{-2}\right)$ nos três cortes …….........................48

12 Matéria seca de raizes $\left(\mathrm{g} \cdot \mathrm{m}^{-3}\right)$ no $1^{\circ}$ e $2^{\circ}$ ano de amostragem ..........................49

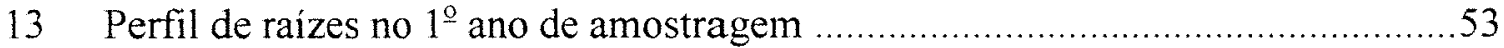

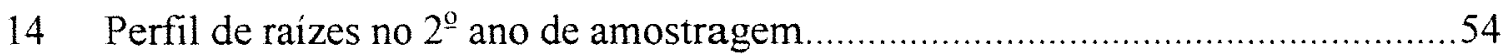

15 Levantamento de população de cigarrinhas (Mahanarva fimbriolata) no $1^{2}$ e $2^{\underline{0}}$

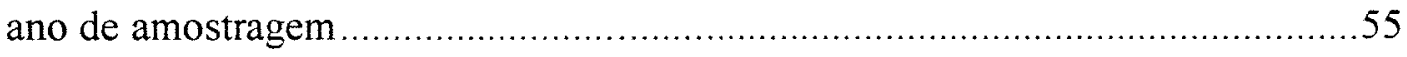

16 Acúmulo de graus-dia $\left({ }^{\circ} \mathrm{C} . \mathrm{dia}^{-1}\right)$ frente ao número de perfilhos / $\mathrm{m}$ linear, no $1^{\circ} \mathrm{e}$

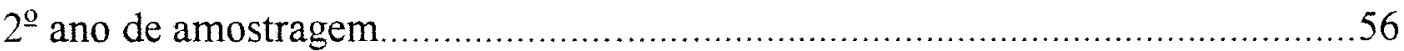

17 Acúmulo de graus-dia $\left({ }^{\circ} \mathrm{C} \cdot \mathrm{dia}^{-1}\right)$ frente ao número de folhas / colmo, no $1^{\mathrm{Q}}$ e $2^{\underline{Q}}$ ano de amostragem. 56 
18 Acúmulo de graus-dia $\left({ }^{\circ} \mathrm{C} \cdot \operatorname{dia}^{-1}\right)$ frente ao diâmetro de colmos, no $1^{\circ}$ e $2^{\circ}$ ano de amostragem

19 Acúmulo de graus-dia $\left({ }^{\circ} \mathrm{C} \cdot \mathrm{dia}^{-1}\right)$ frente à altura de plantas, no $1^{\mathrm{O}}$ e $2^{\mathrm{O}}$ ano de amostragem

20 Acúmulo de graus-dia $\left({ }^{\circ} \mathrm{C} \cdot \mathrm{dia}^{-1}\right)$ frente à matéria seca de colmos, no $1^{\circ}$ e $2^{\circ}$ ano de amostragem .58

21 Acúmulo de graus-dia $\left({ }^{\circ} \mathrm{C} \cdot\right.$ dia $\left.^{-1}\right)$ frente à matéria seca de folhas, no $1^{\circ}$ e $2^{\underline{o}}$ ano de amostragem

22 Acúmulo de graus-dia $\left({ }^{\circ} \mathrm{C} . \operatorname{dia}^{-1}\right)$ frente ao IAF, no $1^{\circ}$ e $2^{\mathrm{Q}}$ ano de amostragem....59

23 Acúmulo de graus-dia $\left({ }^{\circ} \mathrm{C}\right.$ dia $\left.{ }^{-1}\right)$ frente à matéria seca de raízes, no $1^{\circ}$ e $2^{\circ}$ ano de amostragem .60

24 Temperatura de folhas $\left({ }^{\circ} \mathrm{C}\right)$ frente ao número de perfilhos $/ \mathrm{m}$, no $1^{\circ}$ e $2^{\underline{o}}$ ano de amostragem 61

25 Temperatura de folhas $\left({ }^{\circ} \mathrm{C}\right)$ frente ao número de folhas / colmo, no $1^{\underline{o}}$ e $2^{\underline{Q}}$ ano de amostragem .61

26 Temperatura de folhas $\left({ }^{\circ} \mathrm{C}\right)$ frente ao diâmetro de colmos, no $1^{\underline{0}}$ e $2^{\underline{9}}$ ano de amostragem 61

27 Temperatura de folhas $\left({ }^{\circ} \mathrm{C}\right)$ frente à altura de plantas, no $1^{\underline{Q}}$ e $2^{\underline{Q}}$ ano de amostragem

28 Temperatura de folhas $\left({ }^{\circ} \mathrm{C}\right)$ frente à matéria seca de colmos, no $1^{\circ}$ e $2^{\circ}$ ano de amostragem 
29 Temperatura de folhas $\left({ }^{\circ} \mathrm{C}\right)$ frente à matéria seca de folhas, no $1^{\underline{o}}$ e $2^{\mathrm{o}}$ ano de

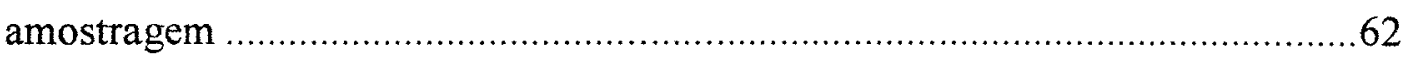

30 Temperatura de folhas $\left({ }^{\circ} \mathrm{C}\right)$ frente ao IAF, no $1^{\circ}$ e $2^{\circ}$ ano de amostragem ..........62

31 Temperatura de folhas $\left({ }^{\circ} \mathrm{C}\right)$ frente à matéria seca de raízes, no $1^{\underline{o}}$ e $2^{\underline{o}}$ ano de amostragem 62

32 Temperatura do solo $\left({ }^{\circ} \mathrm{C}\right)$, em duas profundidades, frente ao número de perfilhos $/$ $\mathrm{m}$, no $1^{\circ}$ e $2^{\circ}$ ano de amostragem 63

33 Temperatura do solo $\left({ }^{\circ} \mathrm{C}\right)$, em duas profundidades, frente ao número de folhas $/$ colmo, no $1^{\circ}$ e $2^{\circ}$ ano de amostragem

34 Temperatura do solo $\left({ }^{\circ} \mathrm{C}\right)$, em duas profundidades, frente ao diâmetro de colmos, no $1^{\circ}$ e $2^{\circ}$ ano de amostragem 65

35 Temperatura do solo $\left({ }^{\circ} \mathrm{C}\right)$, em duas profundidades, frente à altura de plantas, no $1^{\circ}$ e $2^{\circ}$ ano de amostragem. .66

36 Temperatura do solo $\left({ }^{\circ} \mathrm{C}\right)$, em duas profundidades, frente à matéria seca de colmos, no $1^{\underline{Q}}$ e $2^{\underline{Q}}$ ano de amostragem

37 Temperatura do solo $\left({ }^{\circ} \mathrm{C}\right)$, em duas profundidades, frente à matéria seca de folhas, no $1^{\underline{0}}$ e $2^{\underline{0}}$ ano de amostragem .68

38 Temperatura do solo $\left({ }^{\circ} \mathrm{C}\right)$, em duas profundidades, frente ao IAF, no $1^{\circ}$ e $2^{\circ}$ ano de amostragem

39 Temperatura do solo $\left({ }^{\circ} \mathrm{C}\right)$, em duas profundidades, frente à matéria seca de raizes, no $1^{\circ}$ e $2^{-}$ano de amostragem 70

40 Umidade relativa do ar (\%) frente ao número de perfilhos $/ \mathrm{m}$, no $1^{\circ}$ e $2^{\circ}$ ano de amostragem 
41 Umidade relativa do ar (\%) frente ao número de folhas / colmo, no $1^{\circ}$ e $2^{\circ}$ ano de amostragem

42 Umidade relativa do ar (\%) frente ao diâmetro de colmos, no $1^{\circ}$ e $2^{\circ}$ ano de amostragem .72

43 Umidade relativa do ar $(\%)$ frente à altura de plantas, no $1^{\varrho}$ e $2^{\varrho}$ ano de amostragem 72

44 Umidade relativa do ar $(\%)$ frente à matéria seca de colmos, no $1^{\varrho}$ e $2^{\varrho}$ ano de amostragem .73

45 Umidade relativa do ar $(\%)$ frente à matéria seca de folhas, no $1^{\underline{0}}$ e $2^{\circ}$ ano de amostragem 73

46 Umidade relativa do ar (\%) frente ao IAF, no $1^{\circ}$ e $2^{\circ}$ ano de amostragem 74

47 Umidade relativa do ar $(\%)$ frente à matéria seca de raizes, no $1^{\circ}$ e $2^{\circ}$ ano de amostragem 74

48 Umidade relativa de folhas $(\%)$ frente ao número de perfilhos $/ \mathrm{m}$, no $1^{\circ}$ e $2^{\circ}$ ano de amostragem. 75

49 Umidade relativa de folhas $(\%)$ frente ao número de folhas / colmo, no $1^{\circ}$ e $2^{\circ}$ ano de amostragem. 75

50 Umidade relativa de folhas $(\%)$ frente ao diâmetro de colmos, no $1^{\circ}$ e $2^{\circ}$ ano de amostragem . 75

51 Umidade relativa de folhas $(\%)$ frente à altura de plantas, no $1^{\circ}$ e $2^{\circ}$ ano de amostragem 75

52 Umidade relativa de folhas $(\%)$ frente à matéria seca de colmos, no $1^{\circ}$ e $2^{\circ}$ ano de amostragem 
53 Umidade relativa de folhas (\%) frente à matéria seca de folhas, no $1^{\circ}$ e $2^{\circ}$ ano de amostragem 76

54 Umidade relativa de folhas (\%) frente ao IAF, no $1^{\circ}$ e $2^{\circ}$ ano de amostragem.....76

55 Umidade relativa de folhas (\%) frente à matéria seca de raizes, no $1^{\circ}$ e $2^{\circ}$ ano de amostragem 76

56 Umidade relativa do solo $(\%)$, em duas profundidades, frente ao número de perfilhos / $m$, no $1^{\circ}$ e $2^{\underline{o}}$ ano de amostragem .

57 Umidade relativa do solo (\%), em duas profundidades, frente ao número de folhas / colmo, no $1^{\circ}$ e $2^{\circ}$ ano de amostragem .78

58 Umidade relativa do solo $(\%)$, em duas profundidades, frente ao diâmetro de colmos, no $1^{\circ}$ e $2^{\circ}$ ano de amostragem .79

59 Umidade relativa do solo (\%), em duas profundidades, frente à altura de plantas, no $1^{\circ}$ e $2^{\circ}$ ano de amostragem 80

60 Umidade relativa do solo $(\%)$, em duas profundidades, frente à matéria seca de colmos no $1^{\mathfrak{Q}}$ e $2^{\mathrm{Q}}$ ano de amostragem 81

61 Umidade relativa do solo $(\%)$, em duas profundidades, frente à matéria seca de folhas, no $1^{\circ}$ e $2^{o}$ ano de amostragem. 82

62 Umidade relativa do solo $(\%)$, em duas profundidades, frente ao IAF, no $1^{\mathrm{o}}$ e $2^{\mathrm{O}}$ ano de amostragem 83

63 Umidade relativa do solo (\%), em duas profundidades, frente à matéria seca de raízes, no $1^{\circ}$ e $2^{\circ}$ ano de amostragem 84

64 Comparação entre temperatura do ar, da folha e do solo para cana crua e cana queimada no $1^{\circ}$ ano de amostragem 
65 Comparação entre temperatura do ar, da folha e do solo para cana crua e cana queimada no $2^{\circ}$ ano de amostragem 86

66 Comparação entre umidade do ar, da folha e do solo para cana crua e cana

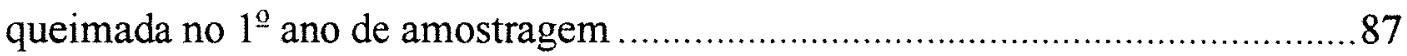

67 Comparação entre umidade do ar, da folha e do solo para cana crua e cana queimada no $2^{\circ}$ ano de amostragem 88 


\section{LISTA DE TABELAS}

Tabela $\mathrm{N}^{\mathrm{O}}$

Página

1 Dias e datas de coleta após a colheita durante os $1^{\circ}$ e $2^{\circ}$ ano de amostragem......21

2 Média dos tratamentos para diâmetro de colmos $(\mathrm{mm})$, aos $308 \mathrm{DAC}$, no $1^{\circ}$ ano de amostragem 32

3 Média dos tratamentos para diâmetro de colmos ( $\mathrm{mm}$ ), aos 37 e 241 DAC, no $2^{\mathrm{Q}}$ ano de amostragem. 33

4 Correlações do diâmetro de colmos com indices biométricos e parâmetros climatológicos aos $308 \mathrm{DAC}$, no $1^{\circ}$ ano de amostragem 33

5 Correlações do diâmetro de colmos com índices biométricos e parâmetros climatológicos aos 37 e 241 DAC, no $2^{\circ}$ ano de amostragem ..........................34

6 Média dos tratamentos para altura de plantas $(\mathrm{cm})$, aos 37,314 e 344 DAC, no $2^{\circ}$

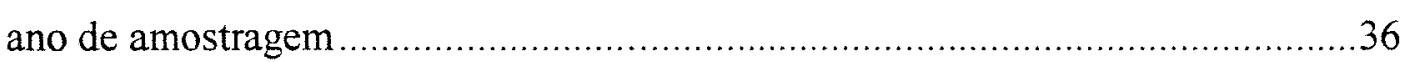

7 Correlações da altura de plantas com indices biométricos e parâmetros climatológicos aos 37,314 e 344 DAC, no $2^{\circ}$ ano de amostragem .....................37

8 Média dos tratamentos para matéria seca de colmos $\left(\mathrm{g} \cdot \mathrm{m}^{-2}\right)$, aos $213 \mathrm{DAC}$, no $1^{\circ}$ ano de amostragem.

9 Média dos tratamentos, para matéria seca de colmos $\left(\mathrm{g} \cdot \mathrm{m}^{-2}\right)$, aos 37 e $272 \mathrm{DAC}$, no $2^{\circ}$ ano de amostragem. 40

10 Correlações da matéria seca de colmos com indices biométricos e parâmetros climatológicos aos 213 DAC, no $1^{\circ}$ ano de amostragem .40 
11 Correlações da matéria seca de colmos com indices biométricos e parâmetros climatológicos aos 37 e $272 \mathrm{DAC}$, no $2^{\circ}$ ano de amostragem

12 Média dos tratamentos para matéria seca de folhas $\left(\mathrm{g} \cdot \mathrm{m}^{-2}\right)$, aos 37 e $272 \mathrm{DAC}$, no $2^{\circ}$ ano de amostragem.

13 Correlações da matéria seca de folhas com índices biométricos e parâmetros climatológicos aos 37 e $272 \mathrm{DAC}$, no $2^{\circ}$ ano de amostragem

14 Média dos tratamentos, para IAF, aos $241 \mathrm{DAC}$, no $2^{\circ}$ ano de amostragem 47

15 Correlações do IAF com índices biométricos e parâmetros climatológicos aos 241 $\mathrm{DAC}$, no $2^{\circ}$ ano de amostragem ..48

16 Média dos tratamentos, para matéria seca de raizes $\left(\mathrm{g} \cdot \mathrm{m}^{-3}\right)$, aos 68,167 e 344 DAC, no $2^{\mathcal{Q}}$ ano de amostragem 49

17 Correlações da matéria seca de raízes com índices biométricos e parâmetros climatológicos aos 68,167 e 344 DAC, no $2^{\circ}$ ano de amostragem 50

18 Média dos tratamentos para matéria seca de raízes em $\mathrm{g} \cdot \mathrm{m}^{-3}$ e em porcentagem, em 5 profundidades de solo, no $1^{\circ}$ ano de amostragem 51

19 Média dos tratamentos para matéria seca de raizes em $\mathrm{g} . \mathrm{m}^{-3} \mathrm{e}$ em porcentagem, em 5 profundidades de solo, no $2^{\circ}$ ano de amostragem 


\title{
COMPARAÇÃO ENTRE O DESENVOLVIMENTO DE CANA CRUA E CANA QUEIMADA EM DOIS CICLOS DE CRESCIMENTO
}

\author{
Autor: IVAN ANDRÉ ALVAREZ \\ Orientador: PAULO R.C. CASTRO
}

\section{RESUMO}

Este trabalho teve como objetivos: comparar o desenvolvimento de cana colhida crua, mecanizada e de cana após a queima, colhida manualmente, utilizando como indicadores de desenvolvimento os seguintes índices biométricos: número de perfilhos, número de folhas, matéria seca de colmos, de folhas e de raizes, índice de área foliar e perfil de raizes; avaliar a influência das temperaturas e das umidades do ar, do solo e das folhas sobre as duas condições de desenvolvimento e analisar o comportamento do crescimento de cana crua e cana queimada nos $1^{\underline{o}}$ e $2^{o}$ anos de rebrota, por meio de curvas adaptadas. A pesquisa foi realizada no município de Morro Agudo, SP, de julho de 1995 a julho de 1997. A variedade cultivada foi a SP $70-1143$. Para cada tratamento utilizaram-se 4 talhões, sendo cada um considerado uma repetição. Adotou-se regressão polinomial e regressão não-linear para se adaptar os dados às 
curvas de crescimento. O desenvolvimento no primeiro ciclo de crescimento foi semelhante para cana crua e cana queimada. No início do segundo ciclo de crescimento ocorreu maior desenvolvimento em cana crua, enquanto que no final, o desenvolvimento foi maior em cana queimada. O perfilhamento da cana crua não apresentou diferenças significativas que confirmem a influência negativa da palha na rebrota. As raizes de cana crua, cresceram em maior quantidade em todas camadas do solo no primeiro ano. A cana crua apresentou valores mais altos do que os da cana queimada, estatisticamente significativos, para os índices biométricos, nas seguintes datas de amostragem: 308 dias após a colheita (DAC), no $1^{\circ}$ ano, para altura de plantas, aos $37 \mathrm{DAC}$, para diâmetro de colmos, altura de plantas, massa seca de colmos e folhas e aos 241 DAC para diâmetro de colmos, no $2^{\circ}$ ano. No que se refere à cana queimada, no $1^{\circ}$ ano, somente houve significância aos 213 DAC, para matéria seca de colmos. No $2^{\circ}$ ano, verificou-se que a partir dos $272 \mathrm{DAC}$, os índices altura de plantas, matéria seca de colmos, folhas e raizes foram os mais significativos. Os dados de IAF foram altos para a cultura de cana-deaçúcar e somente apresentaram relevância aos 241 DAC, com valores maiores para cana queimada. Os fatores climatológicos, isoladamente, não provocaram mudanças de comportamento dos índices biométricos entre a cana crua e cana queimada, em seus ciclos de crescimento, de maneira que se identificasse uma tendência geral. As diferenças de desenvolvimento expressas na curva de crescimento do $1^{\circ}$ para o $2^{\circ}$ ano são devidas aos fatores climatológicos, tanto para cana crua como para cana queimada. 


\title{
COMPARISON BETWEEN THE DEVELOPMENT OF GREEN CANE AND BURNED CANE IN TWO CYCLES OF GROWTH
}

\author{
Author: IVAN ANDRÉ ALVAREZ \\ Adviser: PAULO R.C. CASTRO
}

\section{SUMMARY}

This work had as objectives: to compare the development between green cane, mechanically harvested and cane after being burned, harvest manually, being used as development indicators the following biometric indexes: number of ratoons, number of leaves, dry matter of stalks, leaves and roots, leaf area index (LAI) and profile of roots; to evaluate the influence of the temperature and humiditie of the air, soil and leaves on the two conditions of development and to analyze the behavior of the growth of green cane and cane burned in the $1^{\text {st }}$ and $2^{\text {nd }}$ years of second ratoon cane crop, by means of adapted curves. The research was accomplished in the municipal district of Morro Agudo, SP, from July 1995 to July 1997 . The cultivar was the SP $70-1143$. For each treatment 4 extension boxes were used, being each one considered a repetition. It was adopted polinomial regression and no-linear regression to adapt the data to the growth curves. The development in the first growth cycle was similar for green cane and burned cane. In the beginning of the second growth cycle was absorved larger development in 
green cane, while in the end, the development was larger in burned cane. Tillering of the green cane didn't present significant differences that confirm the negative influence of the straw in the second ratoon cane crop. The green cane presented higher values than the one of the burned cane, statistically significant for the biometric indexes, in the following sampling dates: 308 days after the crop (DAC), in the $1^{\text {st }}$ year, for height of plants, at the $37 \mathrm{DAC}$, for stalk diameter, height of plants, dry matter of stalks and leaves and at the $241 \mathrm{DAC}$, for stalk diameter, in the $2^{\text {nd }}$ year. As far as the burned cane is concerned, in the $1^{\text {st }}$ year, there was only significance at the $213 \mathrm{DAC}$, for dry matter of stalks. In the $2^{\text {nd }}$ year, it was verified that at the 272 DAC on the indexes height of plants, dry matter of stalks, leaves and roots were the most relevant. The data of LAI were high for the sugar cane culture and they only presented relevance at the 241 DAC, with larger rates for burned cane. The climatological factors, separately, didn't promote changes in the behavior of the biometric indexes between the green cane and the burned cane, in theirs growth cycles, so as to identified a general tendency. The differences in the development expressed on the curve of growth from the $1^{\text {st }}$ to the $2^{\text {nd }}$ year are due to the climatological factors, not only to the green cane but also to the burned cane. 


\section{INTRODUÇÃo}

O cultivo de cana-de-açúcar tem sido muito incrementado no Brasil para a produção de açúcar, mas principalmente para obtenção de álcool.

Esse aumento de produção levou a estudos e a implantação de métodos de controle ambiental da cultura canavieira, a várias formas de melhoria do solo, a manipulação genética, a técnicas variadas de plantio e de colheita e a controle de pragas, doenças e plantas invasoras.

Entre os problemas a serem analisados, há a influência sobre a produtividade e sobre o impacto ambiental, causados pela queima da cana. Em decorrência desses questionamentos, é relevante comparar o desenvolvimento da soqueira de cana crua, colhida mecanizadamente, com a de cana queimada, colhida manualmente, práticas essas comumente utilizadas. Essa comparação dá uma idéia de como a condição inicial da planta influencia seu ciclo de crescimento.

É relevante ainda assinalar que, tem-se observado o ataque de cigarrinhas (Mahanarva fimbriolata) no campo, prejudicando a produção de cana crua.

A região adotada para estudo foi a de Ribeirão Preto, onde $70 \%$ da área cultivada com cana-de-açúcar pode ser mecanizada e mais de $50 \%$ da colheita da região já não está sendo feita através de queimadas. Por outro lado, a instalação do experimento em área da Usina Santa Elisa levou em consideração a adoção do cultivo de cana crua por essa empresa em cerca de 17.000 ha, além do apoio à pesquisa.

A análise das consequências do cultivo da cana crua e da queimada, sob o ponto de vista ecofísiológico, pode equacionar questões que, empiricamente, vem sendo levantadas no meio da sociedade em geral. 
Os objetivos desse trabalho foram: comparar o desenvolvimento de cana crua e cana queimada da rebrota até a colheita comercial, a partir dos seguintes índices biométricos: número de perfilhos, número de folhas, matéria seca de colmos, de folhas e de raízes, índice de área foliar e perfil de raízes; avaliar a influência das temperaturas e das umidades do ar, do solo e das folhas sobre as duas condições de desenvolvimento e; analisar o comportamento do crescimento de cana crua e cana queimada nos $1^{\underline{Q}}$ e $2^{\underline{o}}$ anos de rebrota, por meio de curvas adaptadas. 


\section{REVISÃO DE LITERATURA}

O Brasil continua sendo o maior produtor de cana-de-açúcar do mundo e o pais com maior potencial de aumento da área plantada. Nos últimos cinco anos, só a região Centro-Sul, segundo Carvalho (1997), mostrou um considerável aumento de 61,4 milhões de toneladas de cana, uma taxa anual de crescimento de $3,5 \%$ (87/88 a 95/96), sendo que a previsão para os próximos cinco anos é que a produção deva crescer de 40 a 50 milhões de tonelada por ano.

\subsection{Cana crua e cana queimada}

Quando se trata de comparar cana crua e cana queimada, é preciso atentar para o fato de que não há nenhuma comparação científica ainda feita, encontrada em literatura, entre o crescimento da rebrota da cana que foi colhida crua por meio de máquinas e da rebrota da cana que foi colhida após a queimada, manualmente.

Alguns autores têm levantado fatores que diferenciam canas crua e queimada. Furlani Neto (1994) resume as vantagens e desvantagens da cana crua colhida mecanizada e da sobra da palha no canavial. As vantagens são: proteção do solo contra erosão, possibilidade de diminuir terraços, redução do uso de herbicidas, melhor matéria-prima para indústria, maior incorporação de matéria orgânica ao solo, maior atividade microbiana do solo, redução do impacto das gotas de chuva sobre solos agricolas, término da poluição ambiental pelo "carvãozinho". As desvantagens são: ataque de pragas (cigarrinhas da raiz, broca) e doenças (podridões), perigo de incêndio 
no palhiço durante a fase de desenvolvimento, diferentes tipos de brotação sobre o palhiço para cada variedade, queda da produtividade de variedades susceptíveis ao palhiço, difícil utilização em áreas não mecanizáveis e necessidade obrigatória de colhedora, pela dificuldade de cortar canaviais sem queimar, utilizando corte manual.

Soares et al. (1994) acrescentam às vantagens da cana crua o aumento da longevidade da cultura e o menor índice de impurezas minerais e Oliveira et al. (1995), a liberação gradual dos nutrientes a partir da camada de resíduos.

Rozeff (1995b) ressalta ainda, em termos positivos para a cana crua, que a retenção de umidade no palhiço reduz a evaporação da superficie, diminuindo a necessidade de irrigação e que há maior conteúdo de açúcar (4 a 5\%) após a colheita, porque não ocorre perda por exsudação causada pela queimada, resultando em menores custos de cultivo. Por outro lado, os aspectos negativos referem-se a questões de mecanização, como custo elevado, adequabilidade ao sistema e declividade. Em locais frios, a temperatura do solo pode se manter baixa, pela obstrução da penetração dos raios solares, e a umidade favorece a proliferação de fungos e bactérias.

Outras vantagens e desvantagens foram levantadas por Magro (1998) para o sistema de cana crua, entre elas destacam-se as vantagens: fim da penalização por hora de queima; resultando em menor gasto; acaba a pressão físico-psicológica do momento da queimada; ganha-se o tempo que seria desperdiçado no momento da queimada; não há acamamento dos colmos no momento da queimada; há redução nas despesas com cultivo mecânico da soqueira e com herbicidas; aumenta a produtividade agrícola; viabiliza a existência de canaviais ao lado de habitações de cidades, matas, rodovias, ferrovias etc; a cultura da cana passa a ser das mais ecológicas da atualidade e promove o equilíbrio ambiental. Por outro lado, as desvantagens são: aumenta de 5 a $12 \%$ a perda na colheita; torna-se mais difícil colher à noite; há o perigo de fogo durante a colheita ou mesmo após o corte, sendo mais grave, quando este acontece após a brotação da soqueira; é possível que todas as variedades tenham má brotação da soqueira no sistema cana crua, se houver trânsito com compactação na linha das touceiras. 
A queimada é um assunto polêmico e vem causando muitas discussões em encontros e congressos sobre cana-de-açúcar. Por um lado, existem os plantadores tradicionais que temem pelo aumento de custo e desemprego e por outro, o ministério público e as pessoas que se prejudicam com a poluição ambiental. Cabe aos técnicos pesquisar ao máximo as questões que envolvem esse debate para a clareza da discussão.

Em decorrência das consequêencias para as cidades que são circundadas por canaviais, foi estabelecido o decreto $28.895 / 88$ que proibiu a queima de cana-de-açúcar em um raio inferior a $1 \mathrm{~km}$ em torno da zona urbana. Baseando-se em princípios do direito ambiental, Goulart (1997) concluiu que a queimada da cana-de-açúcar é uma atividade tipicamente poluidora, que degrada o meio ambiente, afetando a saúde pública e que o Ministério Público deve tomar iniciativas para combater as queimadas dos canaviais como método de colheita.

Silva (1997) cita a lei 6938/81 referente à compatibilização do desenvolvimento econômico e social com a preservação do meio ambiente e ecológico, para relatar o impacto social da eliminação da queima em diferentes regiões do Estado de São Paulo. A estimativa seria de perda de emprego para $54 \%$ da mão-de-obra que está atualmente trabalhando no corte. Ainda colocado como problema da adoção imediata da colheita da cana crua, o autor observa que tecnicamente pode haver restrição, quando falhas de brotação venham a ocorrer, como na Austrália, onde $40 \%$ da área de cana é queimada por causa dos problemas técnicos com a cana verde.

Rozeff (1995a) relata, a partir dos dados obtidos em 20 anos de informação do Vale do Rio Grande, em Tejas (Havai), que a cana, ao ser queimada, libera apenas 18,2 $\%$ de $\mathrm{CO}_{2}$, fixado durante o crescimento, e consome somente $18,1 \%$ do oxigênio permanentemente liberado, sugerindo que seu beneficio ao meio ambiente é equivalente àquele da cana crua.

Oliveira et al. (1995) avaliaram a produção de um canavial desde a segunda soca, por sete socas consecutivas, encontrando uma diferença de $24 \%$ a mais da produção da cana sem queimar em relação a cana queimada. Também, o balanço de Nitrogênio acumulado confirma que a fixação biológica do Nitrogênio onde se conserva a palha é maior. 
Thompson (1969) conclui, a partir do estudo dos nutrientes do palhiço deixado como "mulch" e da queima do palhiço, que não houve diferenças significativas para a planta. No solo, também não houve diferenças significativas para $\mathrm{P}, \mathrm{K}, \mathrm{Ca}$ e $\mathrm{Mg}$, enquanto que para o Nitrogênio houve perdas por volatilização na cana queimada. O teor de matéria orgânica da cana crua foi significativamente maior em até $0,8 \mathrm{~cm}$ de profundidade, em 23 anos de dados de solo amostrado.

Embora a matéria orgânica tenha seu papel para fornecer nutrientes ao solo, Wood (1969) observou que a presença de material não decomposto no solo do canavial resultou numa competição entre os microorganismos do solo e as plantas pelo Nitrogênio, sendo mais acentuado no início da brotação, havendo a necessidade de complementação para restabelecer a relação $\mathrm{C} / \mathrm{N}$.

A decomposição da palha, por outro lado, pode ser considerada como um fator importante no aumento de produtividade da planta, como considera Pearson (1960) que encontrou maiores produções a partir da segunda soca, à medida que a matéria orgânica do $1^{\underline{Q}}$ e $2^{\underline{Q}}$ cortes foi incorporada ao solo.

Furlani Neto (1995) quantificou as perdas pós-colheita no campo para cana crua e cana queimada, ambas colhidas de forma mecanizada. Através dos seus dados, extrai-se que: na variedade SP 71-1406, a cana crua apresentou cerca de 3,2 vezes mais resíduo no campo que a cana queimada $(9,34 \mathrm{~kg} /$ parcela para $2,92 \mathrm{~kg} /$ parcela); na variedade SP 71-6163, as diferenças entre as perdas foram menores, cerca de 1,1 vezes (de 4,53 kg / parcela para 4,20 kg/ parcela). Já Campos \& Marconato (1994), para o primeiro corte da variedade SP 70-1143, encontraram uma quantidade de palha de $15,607 \mathrm{t} /$ ha, deixada no campo pela cana sem queimar, e 3,801 $\mathrm{t} /$ ha, pela cana que foi queimada: uma diferença de 4,11 vezes. Os mesmos autores, Campos \& Marconato (1994), acompanharam a produtividade de 8 variedades de cana e observaram uma variação de $-9,8 \% \mathrm{a}+14,7 \%$ da cana crua para a cana queimada. A variedade SP 701143 teve uma produtividade de $82,6 \mathrm{t} /$ ha na cana queimada e de $80,8 \mathrm{t}$ / ha de cana crua, uma diferença de $-2,2 \%$. 
A quantidade de palha deixada no campo é diferente para cada variedade e forma de utilização da mecanização (tipo de colhedora, tempo de colheita, quantidade de linhas colhidas etc). Ripoli et al. (1991) mensuraram a quantidade de palha e ponteiro, deixados no campo após a colheita, e o rendimento agrícola em peso seco de diferentes variedades de cana-de-açúcar. Os resultados foram os seguintes, respectivamente para resíduos e rendimento agricola: SP 71-1405 e NA 56-79=14 t/ ha e 75 e $72 \mathrm{t} /$ ha; SP $71-6163$ e SP $70-1143=11 \mathrm{t} /$ ha de e 75 e $88 \mathrm{t} /$ ha e SP $70-1284=7 \mathrm{t} /$ ha e $77 \mathrm{t} / \mathrm{ha}$.

Abramo Filho et al. (1993) encontraram um valor de $15 \mathrm{t} /$ ha de palha e ponteiro deixada no campo e uma produção de $106 \mathrm{t}$ / ha na variedade SP 71-6163, após a colheita da cana crua mecanizada. Os mesmos autores também identificaram os seguintes valores na palhada: umidade $=22,34 \% ; \mathrm{pH}$ da palha em solução salina $=5,35$ e em solução $\mathrm{KCl}=5,38$ e teor de matéria orgânica $=90 \%$.

Zulauf et al. (1985) também encontraram uma umidade de $21,3 \%$ na palha no canavial, em Bauru, para a variedade SP 70-1143, semelhante ao trabalho anteriormente citado, embora a variedade seja diferente.

Através da identificação dos fatores que compõem a palhada, decorrentes da cana crua após a colheita, e de seu potencial energético, alguns trabalhos indicaram a queimada como um desperdício em termos energéticos (Zulauf et al., 1985; Ripoli et al., 1991; Ripoli \& Villanova, 1992 e Furlani Neto, 1995).

Embora o potencial de utilização da palha na indústria seja considerável, o seu uso no campo como "mulch" é o fator principal na mudança do cultivo tradicional da cana-de-açúcar queimada para cana crua. Trabalhos como o de Abramo Filho et al. (1993) indicam mudanças que ocorrem com a presença da palha no campo, como: diminuição da temperatura do solo, maior umidade e retardamento da brotação. Porém, não há quantificação desses efeitos. 


\subsection{Cana-de-açúcar e o clima}

A cana-de-açúcar caracteriza-se por ser uma das culturas que melhor utiliza seu potencial de produtividade em função das condições ideais de clima. Vários autores destacaram temperatura, luminosidade e disponibilidade hídrica como fatores importantes no ciclo dessa cultura.

A necessidade de alta produção de sacarose determina as melhores condições climáticas para a cana: durante a fase de crescimento, um período quente, úmido e com alta radiação solar e durante as fases de maturação e colheita, um período seco, ensolarado e mais frio (Alfonsi et al., 1987).

As altas radiações em grande parte do ano em paises tropicais favorecem o desenvolvimento de plantas do tipo $\mathrm{C}_{4}$. Irvine (1983) aponta a cana-de-açúcar como uma gramínea tropical do tipo $\mathrm{C}_{4}$ e Salisbury \& Ross (1992) destacam as $\mathrm{C}_{4}$ como de alto ponto de saturação lumínica, isto é, capazes de aproveitar melhor o aumento de intensidade luminosa, resultando em uma maior taxa fotossintética.

Blackburn (1984) afirma que a temperatura é o fator mais importante para o crescimento da cultura da cana-de-açúcar e define a temperatura de $30^{\circ} \mathrm{C}$ como ideal para o crescimento e as de 10 a $20^{\circ} \mathrm{C}$, para o amadurecimento e colheita.

Bacchi \& Souza (1978) encontraram temperaturas criticas de $19-20{ }^{\circ} \mathrm{C}$ para o crescimento da cana-de-açúcar, em culturas não irrigadas, enquanto que Brinholi (1972) define as temperaturas criticas de $-2,2 \mathrm{a}-5,5^{\circ} \mathrm{C}$, como prejudiciais as folhas, e de $-1,1$ a $-7,5^{\circ} \mathrm{C}$ aos colmos.

A cana-de-açúcar pode ter o seu processo fotossintético afetado por flutuações rápidas e esparsas de temperatura, Barbieri (1993) cita que a assimilação é aumentada de 1,1 vezes a cada $10^{\circ} \mathrm{C}$ de aumento de temperatura do ar.

Falconier \& Bassereau (1975) afirmam que o crescimento é limitado a partir de $35^{\circ} \mathrm{C}$ e nulo a partir de $38^{\circ} \mathrm{C}$.

A umidade do solo é muito importante como fator ambiental, já que o déficit hidrico é o principal causador de estresse ambiental. Camargo (1968) estabeleceu a 
temperatura média anual de $20^{\circ} \mathrm{C}$ e a deficiência hídrica anual inferior a $200 \mathrm{~mm}$ como condições ambientais adequadas para cana.

Barbieri et al. (1981) encontraram valores de maior perda de água (ETM), que variaram de $0,5 \mathrm{~mm} /$ dia na época de emergência até $6,03 \mathrm{~mm} /$ dia na fase máxima (em novembro, das 11 às 20 horas), decaindo para $2,8 \mathrm{~mm} /$ dia, no início da maturação. Por outro lado, Blackburn (1984) determina a quantidade ao redor de $1.200 \mathrm{~mm} /$ ano como suprimento de água adequado à cultura.

Inman-Bamber \& Jager (1986) estudaram o estresse hídrico a partir do potencial hídrico na folha. A velocidade de crescimento das folhas é reduzida sob estresse hídrico e a aquelas mais jovens começam a enrolar-se a $-0,8 \mathrm{MPa}$; a resistência estomatal aumenta a partir de $-0,8 \mathrm{a}-1,0 \mathrm{MPa}$, a área foliar é reduzida sob potenciais de $-1,0$ a $-1,7 \mathrm{MPa}$. Demonstraram ainda que o crescimento da planta cessa e a condutância atinge um mínimo de $-1,3 \mathrm{a}-1,7 \mathrm{MPa}$, o número de folhas por colmo é reduzido pela metade, a $-2,8 \mathrm{MPa}$; nesse estágio, a morte dos colmos eventualmente, pode ocorrer.

Mongelard \& Mimura (1971) analisaram o efeito da temperatura do ar e da temperatura do ambiente radicular sobre o consumo de água, sobre produção de matéria seca da parte aérea e sobre área foliar. A produção de matéria seca estava correlacionada com o consumo de água, em 98\%. O crescimento das folhas foi mais afetado pela temperatura baixa da raiz do que pela do ar. Por outro lado, não houve efeito da temperatura sobre o indice de transpiração.

Maniero (1980), estudando os efeitos da temperatura no desenvolvimento da cana-de-açúcar, encontrou altos coeficientes de correlação entre tamanho de planta e temperatura. $O$ autor ainda destaca que a ação da temperatura no desenvolvimento pode ser quantificada pela acumulação diária de graus (graus-dia), a partir de uma temperatura-base abaixo da qual o crescimento vegetal é severamente afetado.

Segundo Glasziou et al. (1965), para plantas próximas ao estágio adulto, tanto a área foliar por colmo como a taxa de desenvolvimento dos colmos tendem a um valor constante, o qual é independente da temperatura. 
Fauconier \& Bassereau (1975) afirmaram que o crescimento da cana-deaçúcar é nulo a $18^{\circ} \mathrm{C}$ e normal acima de $20^{\circ} \mathrm{C}$ e que o comprimento dos internódios, seu diâmetro e seu número aumentam consideravelmente, à medida que a temperatura elevase acima de $20^{\circ} \mathrm{C}$. Deste modo, o aumento do comprimento da cana e do volume do colmo são quatro vezes mais efetivos a $25^{\circ} \mathrm{C}$ que a $21^{\circ} \mathrm{C}$.

\subsection{Perfilhamento}

A tendência de perfilhamento das gramíneas em geral apresenta duas fases de desenvolvimento: primeiro, a ramificação e posteriormente, a alongação. Quando está ocorrendo a ramificação, não há alongação e a planta mantém-se com porte reduzido. No caso da cana-de-açúcar, há simultaneidade do crescimento de brotação e da formação de novas ramificações (Camargo, 1968). Este autor ainda descreve o processo de perfilhamento como resultado da regulação por auxinas que, produzidas no topo da planta, descem em fluxo contínuo e estimulam ao mesmo tempo a alongação e previnem o desenvolvimento das gemas laterais.

Em Machado (1987), é apresentado um resumo do padrão de perfilhamento de colmos para cana-planta: 1) fase inicial - o perfilhamento é intenso e atinge um número máximo ao redor de 3 a 5 meses após o plantio; 2) fase intermediária - há morte acentuada de perfilhos, principalmente os que se desenvolveram menos; 3) fase final - o número de perfilhos permanece estável até a colheita.

O padrão de perfilhamento tem-se mostrado característico em diversas variedades de cana-de-açúcar segundo Asana (1950); Machado et al. (1982); Prado (1988); Perin (1996). De acordo com Instituto do Açúcar e do Álcool (1980) e Thompson \& Du Toit (1965) e Gosnell (1968), esse padrão independe das condições hídricas.

Os fatores que influenciam no número final de perfilhos dependem de várias condições determinantes, como: o número máximo, o decréscimo por competição natural e o estabelecimento do número final até a colheita. Prado (1988), trabalhando 
com a variedade SP 70-1143 cớmo cana-soca, encontrou um número máximo de colmos (perfilhos) de 23 e um número final de 13 colmos por metro linear, uma queda de cerca de $45 \%$.

Entre os fatores que influenciam no perfilhamento, a luz talvez seja o mais importante. Christoffoleti (1986) relata que plantas provenientes de casa-de-vegetação, plantadas no campo em condições normais de luminosidade, apresentaram um perfilhamento normal, enquanto que aquelas que foram levadas ao campo em condições de baixa luminosidade, reagiram negativamente, havendo morte de perfilhos. Tal fato demonstra a diminuição da ação de inibição das gemas laterais pelas auxinas, devido à alta luminosidade. Segundo Casagrande (1991), o resultado desse fenômeno é a formação de perfilhos. Dillewijn (1960) relata que se consegue melhor brotação e perfilhamento para cana-soca, à medida que se retira a palha das linhas e se expõem os toletes à luz e ao calor.

A temperatura tem efeito secundário sobre o perfilhamento, uma vez que a alta luminosidade pode compensar o efeito negativo de temperaturas baixas sobre o perfilhamento. Dillewijn (1960) define a temperatura até $30^{\circ} \mathrm{C}$ como estimulante do perfilhamento.

Algumas diferenças entre cana crua e cana queimada já foram relatadas com base na brotação e perfilhamento: Churchward \& Pulsen (1988) citam, como vantagem da cana crua, os melhores perfilhamento e brotação das socas. Por outro lado, Campos \& Marconato (1994) citam que a cana queimada apresenta, nos primeiros meses de rebrota da soqueira, um número maior de perfilhos, supostamente pelo sombreamento e diminuição de temperatura pela palha na cana crua. Já no final do ciclo, o número de perfilhos é semelhante para os dois tipos de cana. 


\subsection{Número de folhas}

O número de folhas presentes no colmo depende basicamente da velocidade com que as folhas são produzidas e da longevidade de cada folha. Camargo (1968) cita que uma folha no Havaí dura 60 a 75 dias, enquanto que em Formosa, as duas folhas mais baixas vivem 30 a 40 dias, as folhas medianas, de 60 a 150 dias e as superiores, de 60 a 90 dias. Humbert (1968) informa que o número máximo de folhas por colmo é de 10 a 15, dependendo da variedade e das condições de crescimento. Portanto, o balanço entre a taxa de emissão e senescência de folhas é dado pelo número de folhas por colmo (Machado et al., 1982).

Segundo Pereira \& Machado (1987), a área foliar de uma planta depende do número e do tamanho das folhas.

\subsection{Diâmetro de colmos}

O diâmetro do colmo é uma medida de crescimento da cana-de-açúcar que vai variar conforme condições gerais da cultura, tais como auto-sombreamento, temperatura do ar e luminosidade. No colmo, ocorre o fenômeno do engrossamento secundário. Em condições anormais de crescimento, o diâmetro dos internódios secundários pode ser afetado.

Camargo (1968) informa que o diâmetro de colmos varia em função da luminosidade, de maneira que em alta luminosidade, os colmos são mais grossos e mais curtos, enquanto que em baixa luminosidade, os colmos são mais finos e mais longos.

O limite inferior da temperatura do ar para o crescimento do diâmetro do colmo foi verificado pelo Instituto do Açúcar e do Álcool (1986) e é de $20^{\circ} \mathrm{C}$. 


\subsection{Altura de plantas}

A altura de plantas é a melhor medida para que se tenha uma idéia da alongação do colmo. Em geral, a altura aumenta com o comprimento do dia (Barbieri et al., 1981). Porém, tratamentos prolongados com temperaturas abaixo de $20^{\circ} \mathrm{C}$ afetam a partição dos fotossintetizados entre a alongação dos colmos e o armazenamento de açúcares. Ao longo do ciclo da cultura, o crescimento do colmo reduz-se à medida que a temperatura diminui, havendo assim alocação dos fotossintetizados para o armazenamento (Glasziou et al., 1965).

\subsection{Matéria seca da parte aérea}

A matéria seca da parte aérea é melhor estimada pela medida das matérias secas de colmos e de folhas, como uma forma de indicar a contribuição de cada um destes órgãos da planta em seu crescimento.

Barbieri (1993) ressalta a importância da determinação da matéria seca de colmo ao indicá-la como representante do tamanho e da massa do mesmo. Salienta, entretanto, que esses dois parâmetros não apresentam necessariamente aumentos paralelos durante o crescimento da planta.

A matéria seca de folhas é um indicador do estabelecimento do aparato fotossintetizador no crescimento.

No início do desenvolvimento, as folhas crescem mais do que o colmo, o que permite à planta tornar-se independente das reservas iniciais da soqueira. Isto foi evidenciado nos trabalhos de San Jose \& Medina (1970), Rostron (1974), Machado et al. (1982) e Yoon (1971), que demonstraram que a matéria seca de folhas é maior que a de colmos na $1^{\underline{a}}$ etapa de crescimento.

Em fases subsequentes, a matéria seca de colmos ultrapassa a de folhas; o momento em que isto ocorre depende das variedades e das condições ambientais. 
San Jose \& Medina (1970) encontraram que a parte aérea alcança $95 \%$ do valor total aos 250-260 dias para cana de ano, na Venezuela, desenvolvida em ano mais seco que o comum (603 mm), porém com irrigação e uma oscilação média anual de temperatura, alcançando $12,1^{\circ} \mathrm{C}$.

Segundo Yoon (1971), a matéria seca da parte aérea contribui com cerca de $90 \%$ do total de matéria seca produzida na colheita. Já Machado et al. (1982), trabalhando com cana de ano e meio, encontraram aos 250 dias, um crescimento de $75 \%$ em relação ao máximo. Os autores adequaram os valores de acúmulo de matéria seca total através da equação logística. Nesses três últimos trabalhos citados, as curvas de crescimento da matéria seca da parte aérea são do tipo sigmóide. Machado (1987) resumiu a evolução do acúmulo de matéria seca em cana-de-açúcar em três fases: 1) fase inicial em que o crescimento é lento; 2) fase de crescimento rápido, onde $70 \%$ a $80 \%$ de toda matéria seca é acumulada e 3) fase final, quando o crescimento é lento, perfazendo $10 \%$ da matéria seca acumulada.

Vários trabalhos, além dos já citados anteriormente, apresentam curvas de crescimento de cana-de-açúcar com formato sigmoidal: Gosnell (1969), McLean et al. (1969), Irvine (1983), Silveira (1985), Rostron (1974) e Brzesowsky (1986).

\section{8 Índice de área foliar}

Índice de área foliar (IAF) é definido como a área foliar dividida pela unidade de área do terreno, o que representa a capacidade que a comunidade vegetal tem de explorar o espaço disponível ( ${ }^{1}$ Watson, 1952 citado por Pereira \& Machado, 1987).

Irvine (1975) relata a utilização do IAF como indicador entre a produtividade de uma cultura e a superficie total fotossintética, enquanto que para Gascho \& Shih (1983), o aumento de IAF prenuncia alta produção de fotossintetizados e alta produção de sacarose.

\footnotetext{
${ }^{1}$ WATSON, D.J. The physiological basic of variation in yield. Advances in Agronomy, v.4, p. 101-145, 1952.
} 
Segundo Brzesowsky (1985), significantes acréscimos de produtividade podem ser conseguidos a partir de um aumento de índice de área foliar, desde que haja um rápido fechamento do dossel em um pequeno periodo de crescimento, aproveitando melhor a radiação incidente. Contudo, Irvine (1983) conclui que mais importante é a taxa fotossintética por unidade de área, a densidade da plantação e depois, a idade da cultura.

Machado et al. (1985) dizem que o máximo índice de área foliar e o melhor aproveitamento da radiação solar vão depender do ângulo de incidência dos raios solares, enquanto que Irvine (1975) já relaciona produtividade com arquitetura foliar, embora Machado et al. (1982) não tenham encontrado diferenças entre IAF de duas variedades de arquiteturas diferentes.

Segundo Casagrande (1991), em regiões onde existe um período de crescimento mais curto, obter-se-iam IAF maiores, diminuindo-se o espaçamento. Irvine \& Benda (1980) verificaram que os menores espaçamentos produziam os maiores índices.

Gascho \& Shih (1983) encontraram o máximo IAF aos 6 meses de idade da planta, enquanto que o número máximo de colmos foi aos 5 meses. Em Machado et al. (1982), o IAF é pequeno no início, crescendo lentamente, seguindo-se um crescimento rápido e estabilização no final (por volta de 300 dias). Yoon (1971) relata que o desenvolvimento do IAF pode ser dividido em 3 fases: muito rápido, dos 60 dias aos 170 dias; uma fase estacionária, até os 300 dias, e uma queda até a colheita. San Jose \& Medina (1970) encontraram o valor máximo de IAF aos 220 dias.

Chang (1968) destaca que o IAF ótimo não é necessariamente o maior, de maneira que, no IAF máximo, a fotossíntese pode não estar ocorrendo em um nível adequado nas folhas inferiores, tendo essas que serem supridas pelos metabólitos das folhas superiores.

A relação entre o IAF e o uso de água pela planta foi estudada por Teruel (1995) que encontrou ser variável o efeito do déficit hídrico sobre o crescimento do IAF na cultura da cana-de-açúcar: com déficit hídrico pequeno, a taxa de crescimento do IAF 
cai mais que a taxa de evapotranspiração e sob déficit hídrico grande, a taxa de crescimento do IAF cai menos que a taxa de evapotranspiração.

\subsection{Raízes}

As raízes desenvolvem-se logo em seguida ao plantio, a partir das reservas do tolete. Blackburn (1984) destaca que no início do desenvolvimento radicular, são formadas as raizes de fixação que suprirão os primórdio foliares que brotarão das gemas.

O desenvolvimento radicular foi mais estudado em cana-planta que em canasoca, por isso há poucas informações sobre o desenvolvimento radicular em cana-soca. Segundo Sampaio et al. (1987), o sistema radicular de cana-de-açúcar merece atenção particular, porque é essencial para a regeneração da cana (soqueira) após a colheita.

Quanto à cana-soca, Casagrande (1991) relata que ao mesmo tempo que vai havendo a brotação das socas, um novo sistema radicular é formado e algumas raizes vivas permanecem alimentando o tolete. Raízes de cana-soca estão mais sujeitas a condições mais adversas do solo causadas pelo tráfego; por isso, pelo ciclo mais curto e pela brotação do tolete dar-se próximo à superfície do solo, as raízes da soca são mais superficiais do que as da cana-planta. Quanto mais cortes forem realizados, maior a possibilidade do sistema radicular das socas localizar-se superficialmente. Por outro lado, no final do ciclo da cana-planta, as raízes mais novas são superficiais, pois ao longo do desenvolvimento radicular, as ramificações secundárias ocorrem após o crescimento em alongamento, nos nós situados mais acima do rebento.

${ }^{2}$ Evans (1936) citado por Camargo (1968), descobriu que uma semana após o corte, a soqueira já apresentava raizes que ocupavam até $15 \mathrm{~cm}$ de profundidade e eram raizes com pêlos absorventes e que, a partir de $15 \mathrm{~cm}$ de profundidade, eram brancas, não tinham pêlos absorventes e eram originárias da cana-planta. Baver et al. (1962)

\footnotetext{
${ }^{2}$ EVANS, H. The root-system of the sugar cane. III. The early development of the root-system of the sugar cane in Mauritius. Emp. J. Exp. Agron.. v.4, p.325-331, 1936
} 
também relataram que depois da primeira colheita de cana de açúcar, o sistema de raiz original fica não-funcional e morre rapidamente.

Fernandes (1979) observou que o sistema radicular de cana-planta é mais desenvolvido que o da rebrota, diferentemente de Ball-Coelho et al. (1992) que relataram a maior quantidade de raízes na cana-soca. Contudo, Ball-Coelho et al. (1992) consideram raízes vivas e mortas, o que já não está claro em Fernandes (1979).

Korndörfer (1989) encontrou uma quantidade maior de matéria seca de raiz de cana-soca, comparado à cana planta, talvez devido à época de amostragem, realizada aos 4,5 meses de idade, com grande possibilidade de haver resíduo do sistema radicular da cana-planta. Já aos 10,6 meses do plantio, num solo Latossolo Vermelho álico, encontraram-se $90 \%$ da massa radicular nos primeiros $30 \mathrm{~cm}$. A variedade SP 70-1143 apresentou maior massa seca de raízes entre os 5 genótipos estudados e encontrou-se uma relação raiz / parte aérea de 10,2\%.

A incorporação de raiz durante o periodo de crescimento também pode constituir um significante acréscimo de material orgânico ao solo e determina o volume efetivo de solo explorado pelas raizes (Ball-Coelho et al., 1992).

Durante o desenvolvimento da cana-de-açúcar, a matéria seca radicular e da parte aérea distribuem-se em função das condições ambientais (Machado, 1987). A variação na distribuição relativa das raizes nas primeiras camadas deve-se principalmente à variação da umidade do solo, segundo Inforzato \& Alvarez (1957).

A cana-de-açúcar desenvolve um sistema radicular aerotrófico (Casagrande, 1991). De acordo com Camargo (1968), o estudo do sistema radicular é importante, porque define uma relação entre a distribuição do sistema radicular e a capacidade da planta de adaptar-se às condições ambientais, por exemplo, à umidade do solo.

A capacidade de absorção de água não depende da quantidade de raizes, mas da área de pêlos absorventes. A distribuição do sistema radicular é muito afetada pela umidade do solo. Nas estações mais secas, as raizes que nascem desenvolvem-se mais profundamente (Camargo, 1968).

Para Sampaio et al. (1987), deve-se dar maior importância ao sistema radicular, porque é ele que serve de reserva de nutrientes para a rebrota das socas. $\mathrm{O}$ 
mesmo autor ainda identificou que $75 \%$ da massa radicular estava localizada nos primeiros $20 \mathrm{~cm}$ superficiais e $55 \%$ estavam a menos de $30 \mathrm{~cm}$ do centro da touceira.

Inforzato \& Alvarez (1957) obtiveram resultados demonstrativos de que a distribuição do sistema radicular apresenta-se bem homogênea, nas camadas superficiais do solo, sendo que o maior adensamento ocorre nos primeiros $30 \mathrm{~cm}(59 \%)$. Já BallCoelho et al. (1992) encontraram $62,69 \%$ da matéria seca total de raizes nos primeiros $50 \mathrm{~cm}$ de profundidade, com $38-48 \%$ das raizes vivas nos $30 \mathrm{~cm}$ iniciais. Esses autores mostraram também que, quando se trata de massa total de raízes, a referência é das raizes mais próximas aos colmos da touceira do que daquelas longe dos mesmos; esse padrão é mais marcante nas camadas superiores do solo, mas não existe abaixo de $1 \mathrm{~m}$. 


\section{MATERIAL E MÉTODOS}

\subsection{Local}

O experimento foi instalado em área da Usina Santa Elisa, Fazenda Barra do Agudo, no município de Morro Agudo, Estado de São Paulo.

A localização do campo experimental está a 509,312 metros de altitude, a $20^{\circ}$ $48^{\prime} 36^{\prime \prime}$ latitude sul e $48^{\circ} 13^{\prime} 37^{\prime \prime}$ longitude oeste.

\subsection{Solo}

O solo do local do experimento é classificado como Latossolo Vermelho Escuro Distrófico.

\subsection{Variedade}

A variedade utilizada foi a SP-701143.

As principais características desta variedade são: ótima brotação da soqueira; produtividade alta; riqueza média em açúcares; florescimento precoce e intenso, com rápida isoporização; maturação precoce tendendo à mediana; pouca exigência em termos de fertilidade do solo; resistência ao carvão e suscetibilidade à ferrugem (Dib Nunes Jr., 1987). 
Almeida (1986), trabalhando com a variedade SP-701143 descreveu as seguintes características morfológicas e bioquímicas: $2,58 \mathrm{~cm}$ de comprimento médio do colmo; $19,67 \mathrm{~cm}$ de número médio de internódios por planta; $29,35 \mathrm{~cm}$ de comprimento médio da bainha; $1,36 \mathrm{~cm}$ de comprimento médio do limbo foliar; $5,41 \mathrm{~cm}$ de largura média da região mediana do limbo foliar; $17,02 \mathrm{~cm}$ de comprimento médio do internódio mediano; $2,52 \mathrm{~cm}$ de diâmetro médio do internódio mediano; 24,86 graus brix de conteúdo médio de sólidos solúveis (sacarose); 6,47 mg / $100 \mathrm{mg}$ de matéria seca, em pH 5,5 e 34,50 mg / $100 \mathrm{mg}$ de matéria seca de proteína total solúvel média, em pH 8,0.

\subsection{Instalação do experimento}

A cana foi plantada em 21 de fevereiro de 1994, em sulcos feitos a uma profundidade de $0,25 \mathrm{~m}$, com um espaçamento entre linhas de $1,35 \mathrm{~m}$ e uma densidade de plantio de 14 gemas / $\mathrm{m}$.

Durante o plantio, adubou-se com torta de filtro (60 kg/ ha), NPK 08-18-00 $(560 \mathrm{~kg} / \mathrm{ha})$ e vinhaça $\left(120 \mathrm{~m}^{3}\right)$, nos sulcos antes da distribuição dos toletes de cana.

\section{5 Época de coleta de dados}

Os dados utilizados para a análise do experimento foram coletados durante dois anos. O primeiro ano da coleta de dados da cana-soca deu-se 37 dias após a primeira colheita, até a segunda colheita. O segundo ano inclui dados coletados a partir de 37 dias, após a segunda colheita da cana, até a terceira. A primeira colheita ocorreu em 16 de julho de 1995 e a segunda, em 24 de julho de 1996. As datas de coleta e dias após a colheita estão na Tabela 1. 
Tabela 1. Dias e datas de coleta após a colheita durante os $1^{\circ}$ e $2^{\underline{Q}}$ ano de amostragem.

\begin{tabular}{|c|c|c|c|c|}
\hline \multirow[b]{2}{*}{ Coleta } & \multicolumn{2}{|c|}{$1^{\circ}$ Ano } & \multicolumn{2}{|c|}{$2^{Q}$ Ano } \\
\hline & Data de coleta & $\begin{array}{c}\text { Dias após a } 1^{\mathrm{a}} \\
\text { colheita* }^{*}(\mathrm{DAC})\end{array}$ & Data de coleta & $\begin{array}{l}\text { Dias após a } 2^{\mathrm{a}} \\
\text { colheita }(\mathrm{DAC})\end{array}$ \\
\hline $1^{\mathrm{a}}$ & $22 / 08 / 95$ & 37 & $30 / 08 / 96$ & 37 \\
\hline $2^{\mathrm{a}}$ & $04 / 10 / 95$ & 80 & $30 / 09 / 96$ & 68 \\
\hline $3^{\mathrm{a}}$ & $07 / 11 / 95$ & 114 & $02 / 11 / 96$ & 101 \\
\hline $4^{\mathrm{a}}$ & $13 / 12 / 95$ & 150 & $02 / 12 / 96$ & 131 \\
\hline $5^{\mathrm{a}}$ & $14 / 02 / 96$ & 213 & $07 / 01 / 97$ & 167 \\
\hline $6^{\mathrm{a}}$ & $19 / 03 / 96$ & 247 & $07 / 02 / 97$ & 198 \\
\hline $7^{\mathrm{a}}$ & $23 / 04 / 96$ & 282 & $22 / 03 / 97$ & 241 \\
\hline $8^{\underline{a}}$ & $19 / 05 / 96$ & 308 & $22 / 04 / 97$ & 272 \\
\hline $9^{\mathrm{a}}$ & $19 / 06 / 96$ & 339 & 03/06/97 & 314 \\
\hline $10^{\mathrm{a}}$ & -- & -- & $03 / 07 / 97$ & 344 \\
\hline Colheita & $24 / 07 / 96\left(2^{a}\right)$ & 374 & $27 / 07 / 97\left(3^{a}\right)$ & 368 \\
\hline
\end{tabular}

\subsection{Tratos culturais na cana-de-açúcar}

Três adubações foram feitas na soqueira: $\left.1^{\text {at }}\right)$ NPK 11-00-44 (300 kg/ ha), para os dois tratamentos; $2^{\mathrm{a}}$ ) NPK 16-00-32 (560 kg/ ha), para cana crua e NPK 18-0036 (500 kg / ha), para cana queimada; $3^{\underline{a}}$ ) cloreto de potássio (300 kg/ ha), para os dois tratamentos. A fórmula (em cobertura) para cana crua é diferente porque o Nitrogênio precisa ser colocado em forma não volátil, já que o fertilizante é colocado em cima da palha (Barbosa, 1997). 


\subsection{Tratamentos}

Os tratamentos utilizados foram dois: $1^{\circ}$ - cana colhida crua (por meio mecanizado) e $2^{\underline{o}}$ - cana colhida queimada (manualmente).

A colheita da cana crua foi feita pela colhedora Santal, modelo Amazón. Após a colheita, não há retirada da palha que permanece no campo devido à falta de queimada. No caso da cana queimada, após a queima efetuada da forma tradicional, a colheita foi realizada manualmente, de acordo com o descrito por Ripoli \& Paranhos (1987).

\subsection{Delineamento estatístico}

Foram destinados 4 talhões com 4 linhas de 20 metros de extensão cada, para cana crua, e 4 linhas de 20 metros de extensão cada, para cana queimada. O talhão foi considerado como repetição. A distribuição dos talhões no campo está esquematizada na Figura 1.

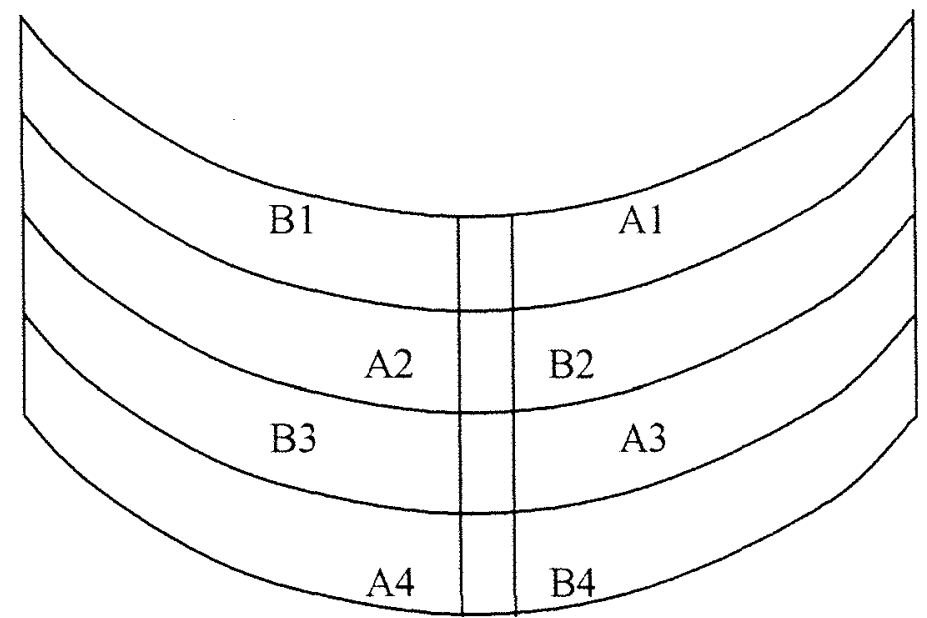
A - Cana Crua
B- Cana Queimada

Figura 1 - Distribuição dos talhões no campo. 


\section{9 Índices biométricos levantados}

\subsubsection{Número de perfilhos (NP)}

A contagem do número de perfilhos foi realizada de maneira direta, em três touceiras por cada uma das repetições, no próprio campo, e depois transformado para perfilho por metro linear.

\subsubsection{Número de folhas (NF)}

A contagem foi efetuada no colmo principal, no campo, de maneira direta, como no número de perfilhos.

\subsubsection{Diâmetro de colmos (DIAM)}

O diâmetro de colmos foi medido com paquímetro MZB (no campo), no primeiro terço do colmo, acima da superfície do solo.

\subsubsection{Altura de plantas (ALT)}

As medidas de altura, diâmetro e número de folhas foram feitas no próprio campo, no colmo principal de cada touceira. Utilizando-se uma fita graduada em centímetros, mediu-se a altura do início do colmo até o colarinho +1 , de acordo com o sistema de KUIJPER, para medida de comprimento.

\subsubsection{Matéria seca de colmos, folhas e parte aérea (MSC, MSF e MSPA)}

Após as medidas realizadas no campo, a cana era transportada para o Laboratório de Fisiologia Vegetal do Departamento de Botânica da Escola Superior de Agricultura "Luiz de Queiroz" (ESALQ / USP). No laboratório, a cana era cortada, separando-se colmos de folhas. Então, o material era submetido à secagem em estufa a $70^{\circ} \mathrm{C}$, por sete dias. Em seguida, a massa do material seco de colmos e folhas de cada touceira era obtida em balança de precisão de três casas, modelo MK CHYO $500 \mathrm{C}$, com resultados expressos em grama por metro quadrado. 
A massa de material seco da parte aérea foi calculada a partir da soma das massas de material seco de colmos e folhas.

\subsection{6 Índice de área foliar (IAF)}

O índice de área foliar foi calculado a partir do cálculo da área foliar obtida pela área de terreno ocupada por cada touceira. Calculou-se a área foliar, usando-se a massa do material seco de discos foliares, com áreas conhecidas, retirados ainda no campo. A balança utilizada para a determinação da massa seca dos cilindros foi a Mettler, com precisão de 3 casas.

\subsubsection{Matéria seca de colmos na colheita (MSCC)}

A massa de material seco de colmos na data da colheita do ciclo de crescimento correspondente não foi levantada diretamente nessa data, pois a última coleta de dados ocorreu 35 dias antes da colheita do $1^{\circ}$ ano, e a 24 dias antes da colheita do $2^{\circ}$ ano. Portanto, foi necessário estimá-la a partir dos dados de produção e perdas na colheita, levantados no campo, em peso fresco. O cálculo da quantidade de matéria seca presente nos colmos na colheita foi obtido, considerando-se que $75 \%$ do colmo contém água (Stupiello, 1987).

\subsubsection{Matéria seca e perfil de raízes (MSR e PR)}

A massa do material seco amostrado das raizes foi obtida através de adaptação do método de Kopke (1981). Após o corte da parte aérea da planta, retiraram-se amostragens das raizes, juntamente com terra, através da utilização de trado manual tradicional (volume $4,1888 \mathrm{~m}^{3}$ ), sem que fosse preciso abrir trincheiras no solo. A amostragem do perfil de raizes das touceiras de cana, constituída de 25 subamostras (volume total $104,72 \mathrm{~m}^{3}$ ), foi definida num perfil de solo perpendicular à cultura, com o eixo da planta na posição central. As subamostras, consideradas cada uma como um volume do trado, foram distribuídas como mostra a Figura 2. 
Em seguida, as porções de solo e raiz das subamostras, obtidas pelo trado, foram separadas em peneira de malha grossa. O solo foi descartado, enquanto que as amostras de raizes levadas ao laboratório foram lavadas com água, para retirada total do solo aderido, e submetidas à secagem em estufa a $70^{\circ} \mathrm{C}$, por três dias.

A quantificação radicular foi feita, utilizando-se a massa de material seco de raiz obtida em pesagem com balança de precisão de 3 casas P $1200 \mathrm{~N}$, com resultados expressos em grama por metro quadrado.

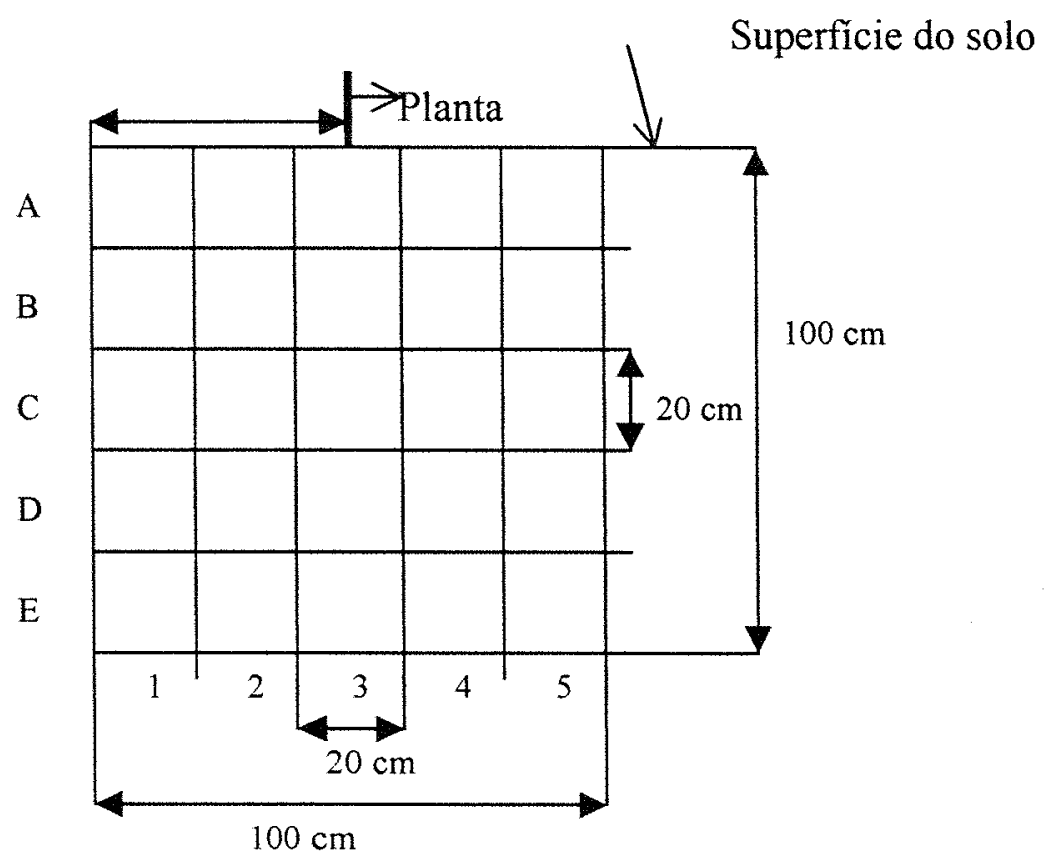

Figura 2 - Desenho esquemático das regiões amostradas para a avaliação radicular. 


\subsection{Dados climatológicos levantados}

\subsubsection{Temperatura do ar e graus -dia (TA e GD)}

Os dados de temperatura média diária do ar $\left({ }^{\circ} \mathrm{C}\right)$ foram fornecidos pelo posto meteorológico instalado na Fazenda Barra do Agudo, onde foi realizado o experimento.

Para analisar os efeitos da temperatura do ar trabalhou-se com a temperatura acumulada em graus-dia nas datas de amostragem. A equação utilizada para o cálculo de graus-dia (Maniero, 1980) foi a seguinte:

$$
\mathrm{GD}\left({ }^{\circ} \mathrm{C} \cdot \mathrm{dia}^{-1}\right)=[((\mathrm{TM}-\mathrm{Tm}) / 2)-\mathrm{TB}] \cdot \mathrm{ND}
$$

$$
\begin{aligned}
& \mathrm{TM}=\text { temperatura máxima } \\
& \mathrm{Tm}=\text { temperatura mínima } \\
& \mathrm{TB}=\text { temperatura base } \\
& \mathrm{ND}=\text { número de dias }
\end{aligned}
$$

A temperatura base é a temperatura a partir da qual o crescimento da planta cessa. Foi adotado $20^{\circ} \mathrm{C}$ como temperatura base, segundo Maniero (1980).

\subsubsection{Temperatura do solo (TS)}

Os dados de temperatura média do solo, em graus Celsius, foram obtidos a partir de medidas pela manhã e à tarde, através de termômetros colocados a $5 \mathrm{~cm}$ (TS 5) e $20 \mathrm{~cm}$ (TS 20) de profundidade, com uma regularidade, em média, de 15 dias.

\subsubsection{Temperatura de folhas (TF)}

A temperatura das folhas foi obtida a partir dos dados do porômetro. 


\subsubsection{Umidade relativa do ar (UA)}

A umidade relativa do ar foi obtida por higrômetro na estação meteorológica da fazenda.

\subsubsection{Umidade relativa na superfície de folhas (UF)}

Os dados de umidade relativa na superficie das folhas foram obtidos no mesmo horário das medidas de transpiração e com o mesmo porômetro.

\subsubsection{Umidade relativa do solo (US)}

A umidade do solo, em termos percentuais, foi avaliada nas profundidades de $0 \mathrm{~cm}$ a $20 \mathrm{~cm}$ (US(0-20)) e de $20 \mathrm{~cm}$ a $40 \mathrm{~cm}$ (US(20-40)), através da diferença de massa entre solo úmido e seco, com uma regularidade, em média, de 15 dias.

\subsection{Levantamento de população de cigarrinhas (Mahanarva fimbriolata)}

A avaliação da população de cigarrinha foi efetuada em 5 pontos de $2 \mathrm{~cm}$ em cada tratamento distribuídos ao acaso nos meses de novembro, dezembro, janeiro e fevereiro, no $1^{\circ}$ ano, e novembro, janeiro e abril, no $2^{\circ}$ ano.

\subsection{Análise estatística}

\subsubsection{Regressão polinomial}

Os dados de diâmetro, número de folhas e acúmulo de graus-dia foram submetidos à regressão polinomial com ajuste da curva de tendência ao longo do tempo, utilizando-se polinômios de $4^{\circ}$ grau. Considerou-se a variável independente $(\mathrm{x})$ como o tempo em dias após a colheita. 


\subsubsection{Regressão não-linear}

Os dados de matéria seca de folha e colmo, índice de área foliar e acúmulo de graus-dia foram ajustados em curvas a partir da equação de crescimento de Gompertz (Oliveira, 1992), sendo que a variável independente $(\mathrm{x})$ era o tempo em dias após a colheita.

\subsubsection{Comparação entre cana crua e cana queimada}

O teste $\mathrm{F}$ (ao nível de 1 e $5 \%$ de significância) foi utilizado para comparar todos os dados de índices biométricos entre cana crua e cana queimada.

\subsubsection{Correlações}

Os dados de índices biométricos foram correlacionados entre si e com os dados climatológicos, através da aplicação do teste de correlação de Pearson (Hoffmann, 1983) 


\section{RESULTADOS}

Os resultados são apresentados em gráficos. As tabelas mostram as datas onde houve diferença significativa e as correlações nessas datas.

\subsection{Número de perfilhos (NP)}

No primeiro e segundo ano, há variações do número de perfilhos ao longo do $1^{\underline{0}}$ ano, sendo elas mais acentuadas no $2^{\underline{o}}$ ano, conforme mostra a Figura 3. Não há, entretanto, diferenças significativas dos valores obtidos nos dois tratamentos.

Cabe salientar, que a rebrota no $1^{\underline{0}}$ ano foi mais intensa que no $2^{\underline{o}}$. $O$ perfilhamento máximo / $\mathrm{m}$ linear, no $1^{\underline{0}}$ ano, tanto para cana crua como para cana queimada, ocorreu aos 37 e 247 DAC. No $2^{\circ}$ ano, o ponto máximo foi aos 101 dias, para cana queimada e 131 para cana crua.
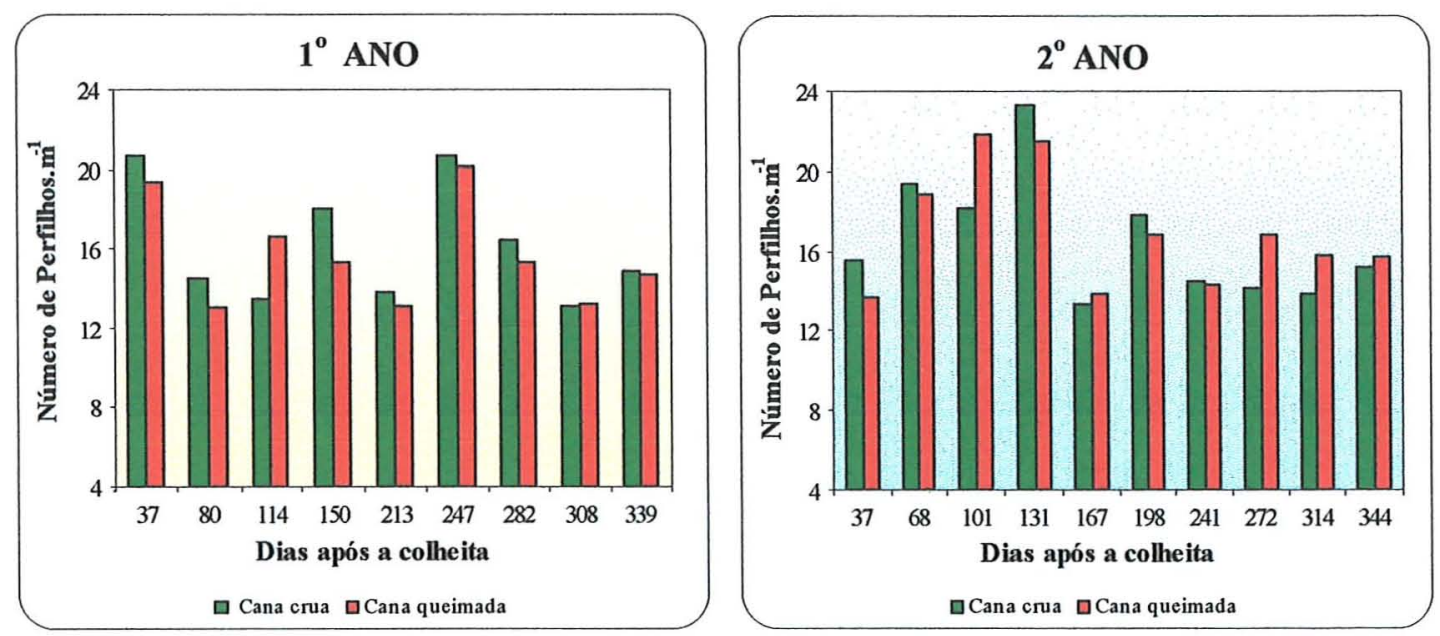

Figura 3 - Número de perfilhos / $\mathrm{m}$ no $1^{\underline{0}}$ e $2^{\underline{o}}$ ano de amostragem. 


\subsection{Número de folhas (NF)}

O crescimento, tomado como parâmetro o número de folhas por colmo (Figura 4), foi maior no $1^{\frac{0}{}}$ que no $2^{\underline{0}}$ ano. Nos dois casos, não há, porém, diferença significante entre os dois tratamentos.
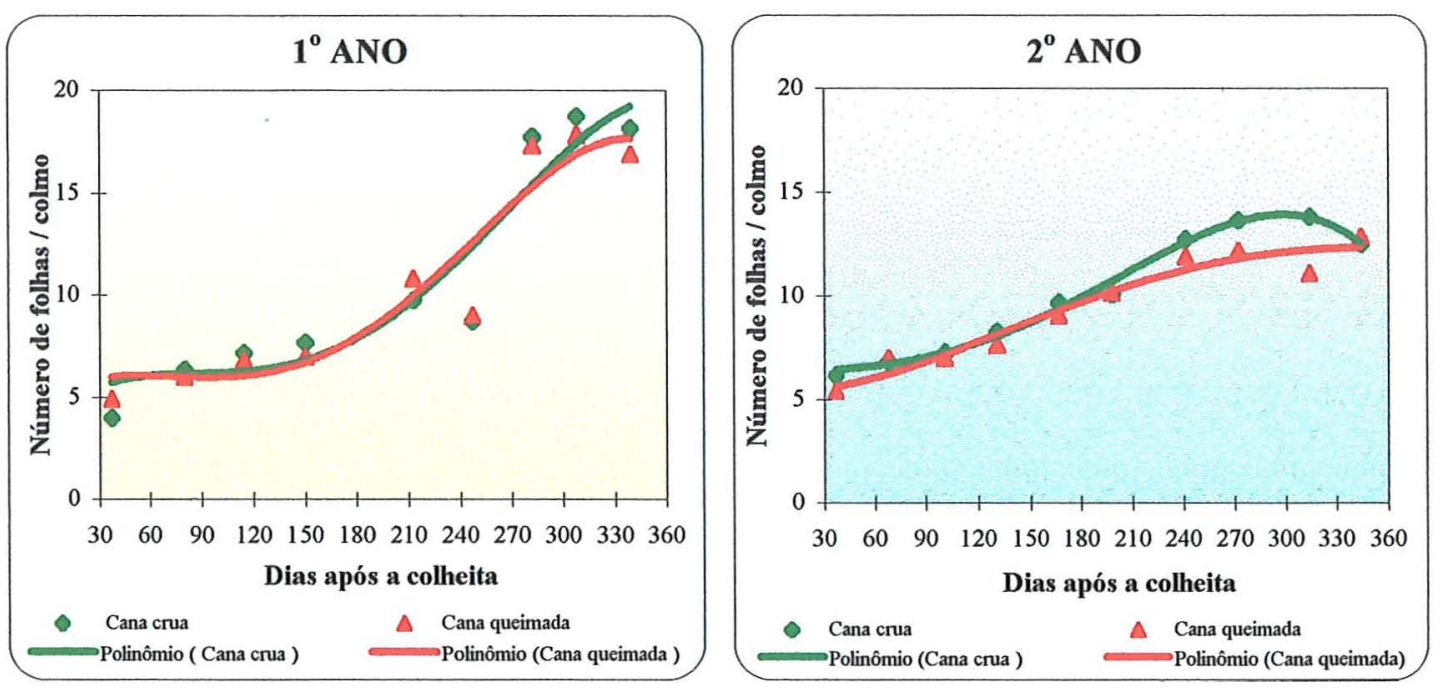

Figura 4 - Número de folhas no $1^{\circ}$ e $2^{\underline{o}}$ ano de amostragem.

As equações que representam as linhas de tendência (curvas de crescimento) e os coeficientes de regressão $\left(\mathrm{R}^{2}\right)$ para cada tratamento estão indicadas a seguir:

$$
\begin{array}{ll}
1^{\circ} \text { ano - cana crua }-\quad & N F=-7 \mathrm{E}-09 \mathrm{x}^{4}+5 \mathrm{E}-06 \mathrm{x}^{3}-0,001 \mathrm{x}^{2}+0,0762 \mathrm{x}+4 \\
& \left(\mathrm{R}^{2}=0,8393\right)
\end{array}
$$

- cana queimada -

$$
\begin{aligned}
& N F=-8 E-09 x^{4}+5 E-06 x^{3}-0,0008 x^{2}+0,0534 x+4,92 \\
& \left(R^{2}=0,9052\right)
\end{aligned}
$$

$2^{\circ}$ ano - cana crua -

$$
\begin{aligned}
& N F=-3 E-09 x^{4}+2 E-06 x^{3}-0,0001 x^{2}+0,0097 x+6,1667 \\
& \left(R^{2}=0,9916\right)
\end{aligned}
$$

- cana queimada -

$$
\begin{aligned}
& N F=9 E-10 x^{4}-1 E-06 x^{3}+0,0003 x^{2}-0,0043 x+5,4167 \\
& \left(R^{2}=0,9493\right) .
\end{aligned}
$$




\subsection{Diâmetro de colmos (DIAM)}

O diâmetro do colmo principal da touceira apresentou um crescimento rápido, no início do ciclo e, posteriormente, uma ligeira queda no primeiro ano e repetiu o comportamento no segundo ano, porém, com valores médios um pouco menores (Figura 5).

As equações e coeficientes de regressão estão a seguir:

$1^{\circ}$ ano - cana crua -

$$
\begin{aligned}
& D(m m)=2 E-08 x^{4}-1 E-05 x^{3}+0,0033 x^{2}-0,1895 x+14,333 \\
& \left(R^{2}=0,9832\right)
\end{aligned}
$$

- cana queimada -

$$
\begin{aligned}
& D(m m)=2 E-08 x^{4}-1 E-05 x^{3}+0,0028 x^{2}-0,1255 x+11,708 \\
& \left(R^{2}=0,9612\right) ; \\
& D(m m)=4 E-09 x^{4}-1 E-06 x^{3}-0,0003 x^{2}+0,1628 x+9,8667 \\
& \left(R^{2}=0,8978\right) ;
\end{aligned}
$$

$2^{\mathfrak{Q}}$ ano - cana crua -

- cana queimada -

$$
\begin{aligned}
& D(m m)=1 E-08 x^{4}-8 E-06 x^{3}+0,0013 x^{2}+0,0211 x+12,158 \\
& \left(R^{2}=0,7972\right) .
\end{aligned}
$$

Durante o $1^{\circ}$ ano, houve diferença relevante aos $308 \mathrm{DAC}$, com a cana crua apresentando maiores valores de diâmetro que a cana queimada (Tabela 2).

No $2^{-}$ano, as diferenças relevantes foram aos 37 e 241 DAC, sendo a cana crua o tratamento que, nas duas datas, apresentou maiores valores (Tabela 3 ). 

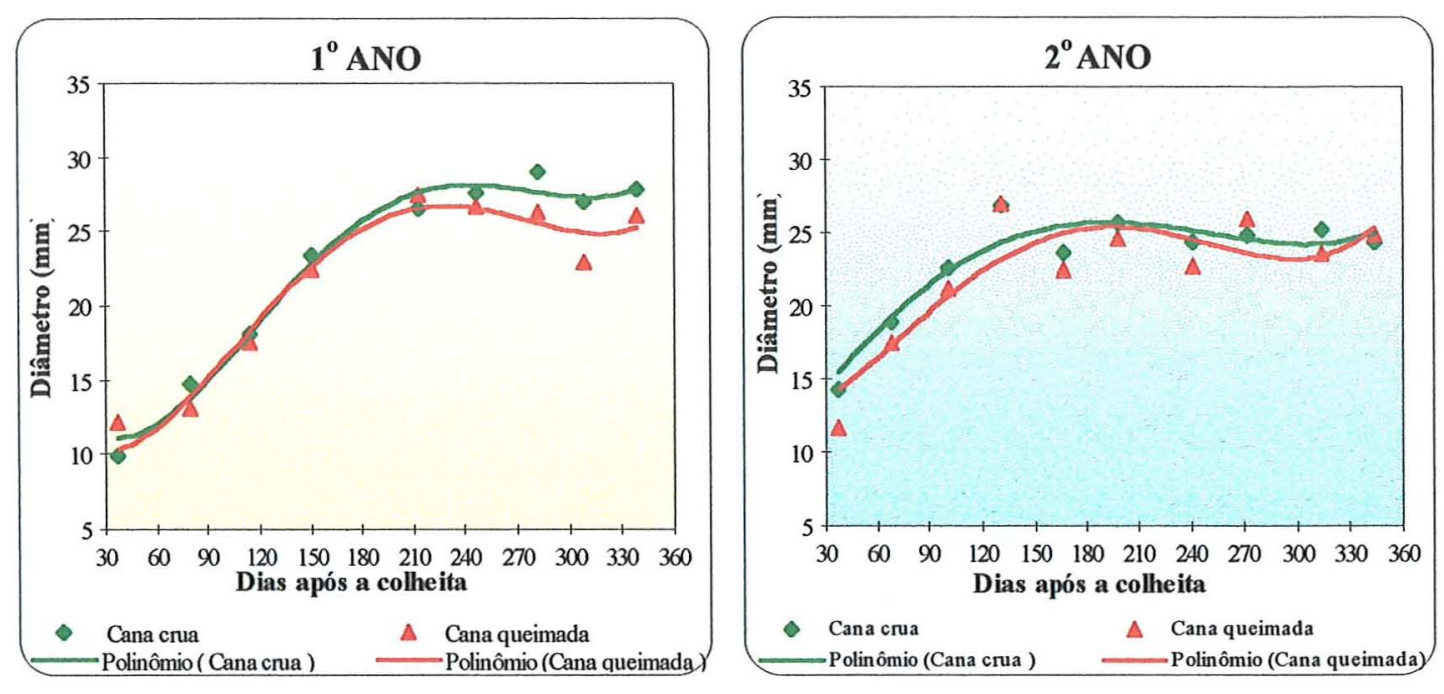

Figura 5 - Diâmetro de colmos (mm) no $1^{\underline{o}}$ e $2^{\underline{o}}$ ano de amostragem.

Tabela 2. Média dos tratamentos para diâmetro de colmos (mm), aos $308 \mathrm{DAC}$, no $1^{\circ}$ ano de amostragem.

\begin{tabular}{cc}
\hline & DIAS APÓS A COLHEITA (DAC) \\
\hline TRATAMENTO & 308 \\
\hline Cana crua & $26,9833 \mathrm{~A}$ \\
Cana queimada & $22,9000 \mathrm{~B}$ \\
\hline F & $9,56 *$ \\
C.V. (\%) & 7,49 \\
\hline
\end{tabular}

* Nível de significância a $5 \%$ de probabilidade 
Tabela 3. Média dos tratamentos para diâmetro de colmos (mm), aos 37 e 241 DAC, no $2^{\circ}$ ano de amostragem.

\begin{tabular}{ccc}
\hline & \multicolumn{3}{c}{ DIAS APÓS A COLHEITA (DAC) } \\
\hline TRATAMENTO & 37 & 241 \\
\hline Cana crua & $14,3333 \mathrm{~A}$ & $24,4000 \mathrm{~A}$ \\
Cana queimada & $11,7083 \mathrm{~B}$ & $22,7917 \mathrm{~B}$ \\
\hline F & $17,53 * *$ & $6,11^{*}$ \\
C.V & 6,81 & 3,90 \\
\hline
\end{tabular}

* Nivel de significância a $5 \%$ de probabilidade

** Nivel de significância a 1\% de probabilidade

As correlações obtidas entre o diâmetro de colmos e os outros índices biométricos e entre diâmetro e parâmetros climatológicos, para as datas de significância entre os tratamentos, são apresentados nas Tabelas 4 e 5.

Tabela 4. Correlações do diâmetro de colmo com índices biométricos e parâmetros climatológicos aos $308 \mathrm{DAC}$, no $1^{\mathrm{o}}$ ano de amostragem.

\begin{tabular}{ccccccccc}
\hline \multicolumn{7}{c}{ INDICES BIOMETRICOS } \\
\hline TRATAMENTO & NP & NF & ALT & MSC & MSF & MSR & IAF \\
\hline Cana crua & $-0,8856$ & 0,0997 & 0,2526 & $-0,2632$ & $-0,6496$ & -- & $-0,7609$ \\
Cana queimada & $-0,3333$ & 0,8510 & $0,9500^{*}$ & $-0,4148$ & $-0,0966$ & $-\ldots$ & $-0,5354$ \\
\hline \multicolumn{7}{c}{ PARÀMETROS CLIMATOLÓGICOS } \\
\hline TRATAMENTO & TS 5 & TS 20 & TF & US $(0-20)$ & US $(20-40)$ & UF \\
\hline Cana crua & $-0,2734$ & 0,2734 & $-0,0655$ & $-0,5903$ & $-0,9547^{*}$ & $-0,1395$ \\
Cana queimada & 0,5774 & $-0,5774$ & $-1,000 * *$ & $-0,4839$ & $-0,4355$ & 0,8993 \\
\hline * Nivel de significância a $5 \%$ de probabilidade & & & \\
$* *$ Nivel de significância a $1 \%$ de probabilidade & & &
\end{tabular}


Tabela 5. Correlações do diâmetro de colmo com índices biométricos e parâmetros climatológicos aos 37 e 241 DAC, no $2^{\underline{o}}$ ano de amostragem.

\begin{tabular}{|c|c|c|c|c|c|c|c|}
\hline 37 DAC & \multicolumn{7}{|c|}{ ÍNDICES BIOMÉTRICOS } \\
\hline TRATAMENTO & NP & NF & ALT & $\mathrm{MSC}$ & MSF & MSR & IAF \\
\hline Cana crua & $-0,7761$ & 0,5320 & 0,1135 & 0,6156 & 0,7747 & $-0,4168$ & 0,6791 \\
\hline \multirow[t]{2}{*}{ Cana queimada } & 0,5773 & 0,1741 & 0,3380 & $-0,1466$ & $-0,5222$ & 0,8686 & $-0,3143$ \\
\hline & \multicolumn{7}{|c|}{ PARÂMETROS CLIMATOLÓGICOS } \\
\hline TRATAMENTO & \multicolumn{2}{|c|}{ TS 5} & \multicolumn{2}{|l|}{ TS 20} & US $(0-20)$ & \multicolumn{2}{|c|}{ US $(20-40)$} \\
\hline Cana crua & \multicolumn{2}{|c|}{$-0,8464$} & \multicolumn{2}{|l|}{$-0,8464$} & 0,2227 & \multicolumn{2}{|c|}{0,6150} \\
\hline Cana queimada & \multicolumn{2}{|c|}{$-0,5773$} & \multicolumn{2}{|l|}{$-0,5773$} & $-0,7087$ & \multicolumn{2}{|c|}{$-0,1839$} \\
\hline 241 DAC & \multicolumn{7}{|c|}{ ÍNDICES BIOMÉTRICOS } \\
\hline TRATAMENTO & NP & NF & ALT & $\mathrm{MSC}$ & MSF & MSR & IAF \\
\hline Cana crua & $-0,8416$ & $-0,9690^{*}$ & $-0,0410$ & $-0,1926$ & $-0,4647$ & $-0,1328$ & 0,0075 \\
\hline \multirow[t]{2}{*}{ Cana queimada } & 0,1072 & 0,9971 & $-0,5386$ & $-0,3909$ & 0,5756 & $-0,6795$ & 0,8657 \\
\hline & \multicolumn{7}{|c|}{ PARÂMETROS CLIMATOLÓGICOS } \\
\hline TRATAMENTO & \multicolumn{2}{|c|}{ TS 5} & \multicolumn{2}{|l|}{ TS 20} & US $(0-20)$ & \multicolumn{2}{|c|}{ US $(20-40)$} \\
\hline Cana crua & \multicolumn{2}{|c|}{$0,9511^{*}$} & \multicolumn{2}{|l|}{$0,9511^{*}$} & $-0,0832$ & \multicolumn{2}{|c|}{0,0316} \\
\hline Cana queimada & \multicolumn{2}{|c|}{$-0,5773$} & \multicolumn{2}{|l|}{0,5773} & 0,4766 & \multicolumn{2}{|c|}{0,2901} \\
\hline
\end{tabular}

* Nivel de significância a 5\% de probabilidade 


\subsection{Altura de plantas (ALT)}

As curvas de crescimento de altura de plantas apresentaram uma forma sigmoidal nos dois anos de amostragem (Figura 6).

$\mathrm{Na}$ comparação entre médias dos dois tratamentos não houve diferenças significativas durante o $1^{\circ}$ ano, em contraste com o $2^{\circ}$ ano, que apresentou diferenças aos 37,314 e 344 DAC (tabela 6), sendo os maiores valores aos 37 DAC para cana crua e aos 314 e 344 DAC para cana queimada.

Ao longo do tempo, para altura de plantas, as curvas foram obtidas através da equação de Gompertz. As equações e os coeficientes de regressão $\left(R^{2}\right)$ obtidos foram os seguintes:

$1^{\circ}$ ano - cana crua -

$$
\begin{aligned}
& \operatorname{ALT}(\mathrm{cm})=313,4978^{14,5357^{0,0145 x}} \\
& \left.\mathrm{R}^{2}=0,8393\right)
\end{aligned}
$$

- cana queimada -

$$
\begin{aligned}
& \operatorname{ALT}(\mathrm{cm})=301,7307^{19,8389^{0,0167 x}} \\
& \left(\mathrm{R}^{2}=0,9052\right)
\end{aligned}
$$

$2^{\circ}$ ano - cana crua --

$$
\begin{aligned}
& \operatorname{ALT}(\mathrm{cm})=332,7167^{5,5907^{0,0145 x}} \\
& \left(\mathrm{R}^{2}=0,9916\right)
\end{aligned}
$$

- cana queimada -

$$
\begin{aligned}
& \operatorname{ALT}(\mathrm{cm})=287,7393^{5,0598^{0,0120 x}} \\
& \left(\mathrm{R}^{2}=0,9980\right)
\end{aligned}
$$


As correlações que demonstram a significância dos índices biométricos relacionados entre si e com os fatores ambientais, para o $2^{\underline{0}}$ ano, aos 37,314 e 344 dias, estão expressos na Tabela 7.
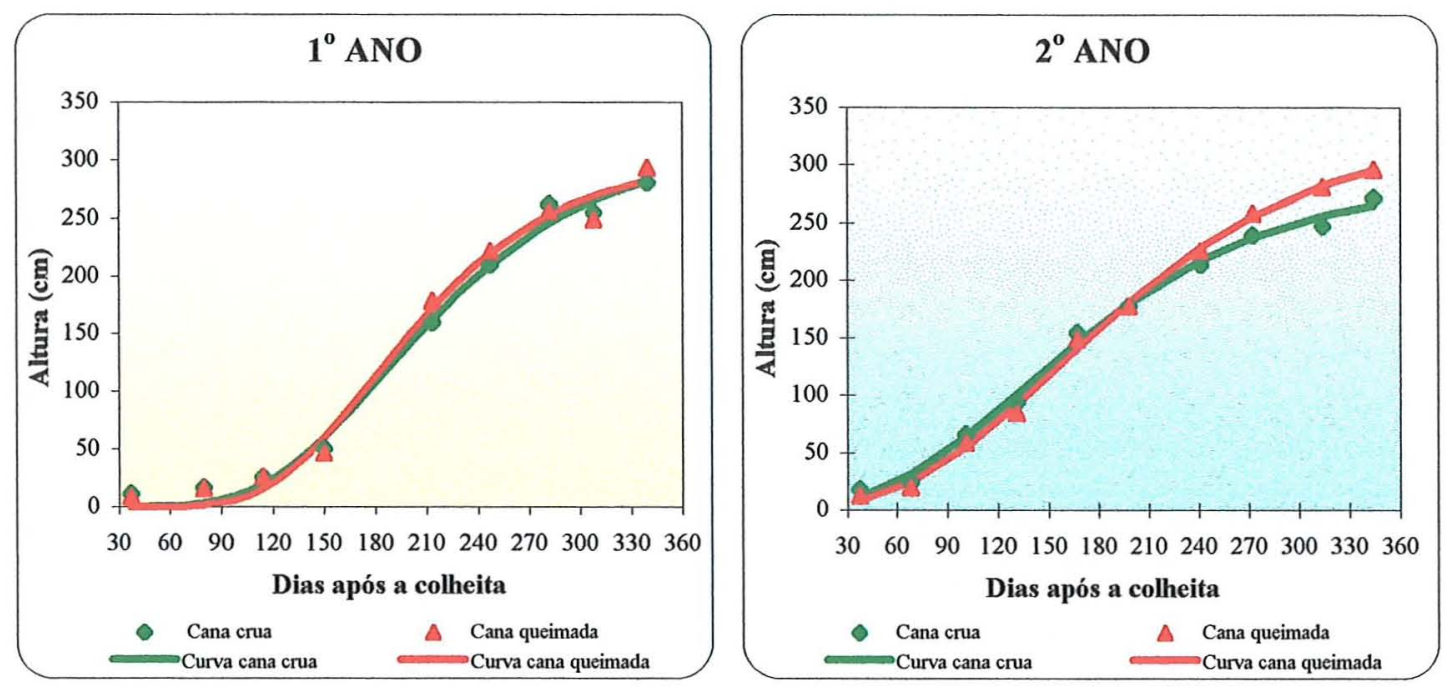

Figura 6 - Altura de plantas $(\mathrm{cm})$ no $1^{\circ}$ e $2^{\circ}$ ano de amostragem.

Tabela 6. Média dos tratamentos, para altura de plantas (cm) aos 37 e 314 e 344 DAC, no $2^{\underline{0}}$ ano de amostragem.

\begin{tabular}{cccc}
\hline & \multicolumn{3}{c}{ DIAS APÓS A COLHEITA (DAC) } \\
\hline TRATAMENTO & 37 & 314 & 344 \\
\hline Cana crua & $18,1709 \mathrm{~A}$ & $247,5000 \mathrm{~B}$ & $271,9167 \mathrm{~B}$ \\
Cana queimada & $12,7500 \mathrm{~B}$ & $280,6667 \mathrm{~A}$ & $296,1667 \mathrm{~A}$ \\
\hline F & $12,59 *$ & $11,48 *$ & $9,97 *$ \\
C.V. & 13,97 & 5,24 & 3,82 \\
\hline
\end{tabular}

* Nivel de significância a $5 \%$ de probabilidade 
Tabela 7. Correlações da altura de plantas com índices biométricos e parâmetros climatológicos, aos 37,314 e 344 DAC, no $2^{\circ}$ ano de amostragem.

\begin{tabular}{|c|c|c|c|c|c|c|c|}
\hline 37 DAC & \multicolumn{7}{|c|}{ ÍNDICES BIOMÉTRICOS } \\
\hline TRATAMENTO & NP & NF & DIAM & MSC & MSF & MSR & IAF \\
\hline Cana crua & 0,2155 & $-0,2910$ & 0,1135 & 0,8502 & 0,7095 & 0,4168 & 0,8022 \\
\hline \multirow[t]{2}{*}{ Cana queimada } & 0,2113 & 0,8505 & 0,3380 & 0,8787 & 0,6259 & 0,54116 & 0,7807 \\
\hline & \multicolumn{7}{|c|}{ PARÂMETROS CLIMATOLÓGICOS } \\
\hline TRATAMENTO & \multicolumn{2}{|l|}{ TS 5} & \multicolumn{2}{|l|}{ TS 20} & US $(0-20)$ & \multicolumn{2}{|c|}{ US $(20-40)$} \\
\hline Cana crua & \multicolumn{2}{|c|}{$-0,8464$} & \multicolumn{2}{|l|}{$-0,8464$} & 0,2227 & \multicolumn{2}{|c|}{0,6150} \\
\hline Cana queimada & \multicolumn{2}{|l|}{0,4790} & \multicolumn{2}{|l|}{0,4790} & 0,2374 & \multicolumn{2}{|c|}{0,6172} \\
\hline 314 DAC & \multicolumn{7}{|c|}{ INDICES BIOMÉTRICOS } \\
\hline TRATAMENTO & NP & NF & ALT & MSC & MSF & MSR & IAF \\
\hline Cana crua & 0,4850 & 0,2550 & 0,1960 & 0,2507 & 0,8569 & $-0,4185$ & $0,9635^{*}$ \\
\hline \multirow[t]{2}{*}{ Cana queimada } & $-0,6679$ & $-0,6850$ & $-0,6679$ & $-0,2149$ & $-0,7071$ & $-0,4197$ & $-0,7200$ \\
\hline & \multicolumn{7}{|c|}{ PARÂMETROS CLIMATOLÓGICOS } \\
\hline TRATAMENTO & \multicolumn{2}{|l|}{ TS 5} & \multicolumn{2}{|c|}{ TS 20} & US $(0-20)$ & \multicolumn{2}{|c|}{ US $(20-40)$} \\
\hline Cana crua & \multicolumn{2}{|c|}{$-0,6592$} & \multicolumn{2}{|l|}{0,6592} & $-0,1053$ & \multicolumn{2}{|c|}{$-0,3038$} \\
\hline Cana queimada & \multicolumn{2}{|c|}{0,2314} & \multicolumn{2}{|l|}{$-0,2317$} & $-0,6199$ & \multicolumn{2}{|c|}{$-0,2415$} \\
\hline 344 DAC & \multicolumn{7}{|c|}{ ÍNDICES BIOMÉTRICOS } \\
\hline TRATAMENTO & NP & NF & ALT & $\mathrm{MSC}$ & MSF & MSR & IAF \\
\hline Cana crua & $0,9760^{*}$ & -0.5035 & 0,1269 & 0,8643 & 0,3900 & 0,4828 & 0,2264 \\
\hline \multirow[t]{2}{*}{ Cana queimada } & $-0,9044$ & $-0,9241$ & $-0,6082$ & $-0,2523$ & 0,9147 & $-0,6861$ & $-0,8957$ \\
\hline & \multicolumn{7}{|c|}{ PARÀMETROS CLIMATOLÓGICOS } \\
\hline TRATAMENTO & \multicolumn{2}{|c|}{ TS 5} & \multicolumn{2}{|l|}{ TS 20} & US $(0-20)$ & \multicolumn{2}{|c|}{ US $(20-40)$} \\
\hline Cana crua & $-0,469$ & & 0,4692 & & 0,4289 & & 5262 \\
\hline Cana queimada & 0,345 & & $-0,3454$ & & $-0,6404$ & & 8398 \\
\hline
\end{tabular}




\subsection{Matéria seca de colmos (MSC)}

$\mathrm{O}$ índice biométrico massa seca de colmos apresentou curvas de crescimento no $1^{\underline{0}}$ ano, para cana crua e cana queimada, que apresentaram 2 fases de desenvolvimento, enquanto que no $2^{\circ}$ houve 3 fases para os dois tratamentos (Figura 7).

As curvas adaptadas à matéria seca de colmos apresentaram as seguintes equações (de Gompertz) e coeficientes de regressão:

$1^{\circ}$ ano - cana crua -

$\operatorname{MSC}\left(\mathrm{g} \cdot \mathrm{m}^{-2}\right)=11882,0727^{8,0989^{0,0055 x}}$

$\left(\mathrm{R}^{2}=0,9739\right)$;

- cana queimada -

$$
\begin{aligned}
& \operatorname{MSC}\left(\mathrm{g} \cdot \mathrm{m}^{-2}\right)=6069,2232^{12,2225^{0,0090 x}} \\
& \left(\mathrm{R}^{2}=0,9835\right)
\end{aligned}
$$

$2^{\circ}$ ano - cana crua -

$$
\begin{aligned}
& \operatorname{MSC}\left(\mathrm{g} \cdot \mathrm{m}^{-2}\right)=1883,1977^{20,1951^{0,0200 x}} \\
& \left(\mathrm{R}^{2}=0,9905\right)
\end{aligned}
$$

- cana queimada -

$$
\begin{aligned}
& \operatorname{MSC}\left(\mathrm{g} \cdot \mathrm{m}^{-2}\right)=2836,2306^{8,3736^{0,0115 x}} \\
& \left(\mathrm{R}^{2}=0,9890\right)
\end{aligned}
$$



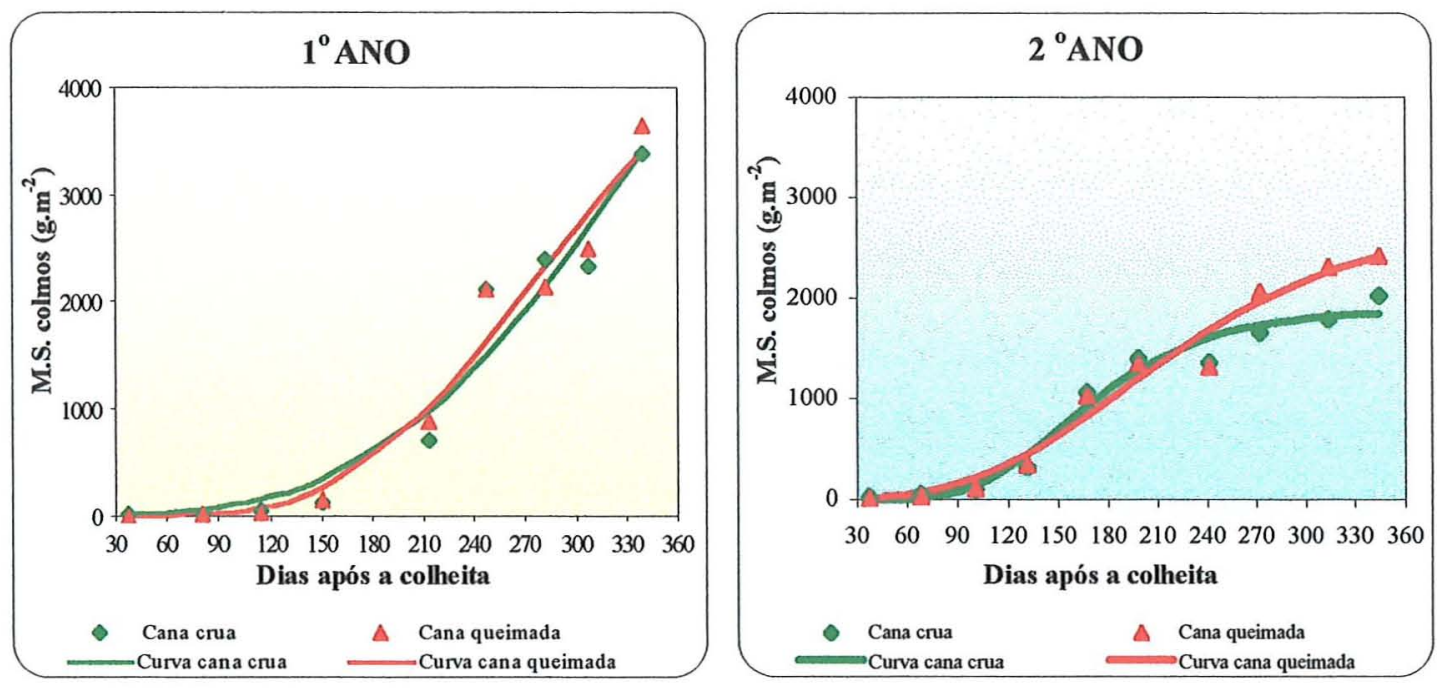

Figura 7 - Matéria seca de colmos $\left(\mathrm{g} \cdot \mathrm{m}^{-2}\right)$ no $1^{\mathrm{o}}$ e $2^{\underline{o}}$ ano de amostragem.

Os dados apresentados na Tabela 8, a seguir, mostram uma diferença significativa na comparação de tratamentos aos $213^{\circ} \mathrm{DAC}$, no $1^{\circ}$ ano, sobressaindo-se a cana queimada. Por outro lado, no $2^{\circ}$ ano, as diferenças foram significativas aos 37 , para cana crua e 272 dias, para cana queimada (Tabela 9).

$\mathrm{Na}$ Tabela 10, estão expressas as correlações aos $213 \mathrm{DAC}$, no $1^{\mathrm{o}}$ ano e, na Tabela 11, as correlações para os 37 e 272 DAC no $2^{\circ}$ ano.

Tabela 8. Média dos tratamentos para matéria seca de colmos (g.m $\left.{ }^{-2}\right)$, aos 213 DAC, no $1^{\underline{0}}$ ano de amostragem.

\begin{tabular}{cc}
\hline & DIAS APÓS A COLHEITA (DAC) \\
\hline TRATAMENTO & 213 \\
\hline Cana crua & $702,5343 \mathrm{~B}$ \\
Cana queimada & $875,0974 \mathrm{~A}$ \\
\hline F & $8,65 *$ \\
C.V. (\%) & 10,52 \\
\hline
\end{tabular}

\footnotetext{
* Nivel de significância a 5\% de probabilidade
} 
Tabela 9. Média dos tratamentos para matéria seca de colmos $\left(\mathrm{g} \cdot \mathrm{m}^{-2}\right)$, aos 37 e 272 $\mathrm{DAC}$, no $2^{\circ}$ ano de amostragem.

\begin{tabular}{ccc}
\hline & \multicolumn{2}{c}{ DIAS APÓS A COLHEITA (DAC) } \\
\hline TRATAMENTO & 37 & 272 \\
\hline Cana crua & $17,7780 \mathrm{~A}$ & $1654,3417 \mathrm{~B}$ \\
Cana queimada & $8,8890 \mathrm{~B}$ & $2058,4208 \mathrm{~A}$ \\
\hline F & $24,30^{* *}$ & $10,90^{*}$ \\
C.V. & 19,13 & 9,32 \\
\hline
\end{tabular}

* Nivel de significância a $5 \%$ de probabilidade

** Nivel de significância a 1\% de probabilidade

Tabela 10. Correlações da matéria seca de colmos com indices biométricos e parâmetros climatológicos aos $213 \mathrm{DAC}$, no $1^{\circ}$ ano de amostragem.

\begin{tabular}{ccccccccc}
\hline \multicolumn{7}{c}{ INDICES BIOMÉTRICOS } \\
\hline TRATAMENTO & NP & NF & DIAM & ALT & MSF & MSR & IAF \\
\hline Cana crua & $-0,0695$ & $-0,5394$ & 0,8185 & 0,8685 & 0,9450 & 0,5067 & 0,1782 \\
Cana queimada & $-0,7933$ & $-0,4698$ & 0,4698 & 0,3732 & 0,0069 & 0,2242 & $-0,4078$ \\
\hline \multicolumn{7}{c}{ PARÀMETROS CLIMATOLÓGICOS } \\
\hline TRATAMENTO & TS 5 & TS 20 & TF & US $(0-20)$ & US $(20-40)$ & UF \\
\hline Cana crua & $-0,0092$ & $-0,0092$ & $-0,7979$ & $-0,8245$ & 0,6363 & 0,4637 \\
Cana queimada & $-0,2441$ & $-0,2441$ & $-0,4698$ & 0,5293 & $-0,2257$ & 0,2657 \\
\hline
\end{tabular}


Tabela 11. Correlações da matéria seca de colmos com índices biométricos e parâmetros climatológicos, aos 37 e $272 \mathrm{DAC}$, no $2^{\circ}$ ano de amostragem.

\begin{tabular}{|c|c|c|c|c|c|c|c|}
\hline 37 DAC & \multicolumn{7}{|c|}{ ÍNDICES BIOMÉTRICOS } \\
\hline TRATAMENTO & NP & NF & DIAM & $\mathrm{ALT}$ & MSF & MSR & IAF \\
\hline Cana crua & $-0,2734$ & 0 & 0,6156 & 0,8502 & $0,9623 *$ & 0,6957 & 0,9862 \\
\hline \multirow[t]{2}{*}{ Cana queimada } & 0,1267 & 0,8424 & $-0,1466$ & 0,8787 & 0,9190 & 0,1007 & $0,9672^{*}$ \\
\hline & \multicolumn{7}{|c|}{ PARÂMETROS CLIMATOLÓGICOS } \\
\hline TRATAMENTO & \multicolumn{2}{|l|}{ TS 5} & \multicolumn{2}{|l|}{ TS 20} & US $(0-20)$ & \multicolumn{2}{|c|}{ US (20-40) } \\
\hline Cana crua & \multicolumn{2}{|l|}{$-0,7071$} & \multicolumn{2}{|l|}{$-0,7071$} & $-0,6092$ & \multicolumn{2}{|c|}{$-0,2417$} \\
\hline Cana queimada & \multicolumn{2}{|l|}{0,7620} & \multicolumn{2}{|l|}{0,7620} & 0,6404 & \multicolumn{2}{|c|}{0,7888} \\
\hline $272 \mathrm{DAC}$ & \multicolumn{7}{|c|}{ ÍNDICES BIOMÉTRICOS } \\
\hline TRATAMENTO & NP & NF & DIAM & ALT & MSF & MSR & IAF \\
\hline Cana crua & 0,5525 & $-0,9258$ & $-0,6885$ & 0,0025 & 0,1577 & $-0,0380$ & $-0,0318$ \\
\hline \multirow[t]{2}{*}{ Cana queimada } & 0,5983 & $-0,7651$ & 0,9166 & 0,2754 & 0,8534 & 0,6987 & 0,1826 \\
\hline & \multicolumn{7}{|c|}{ PARÂMETROS CLIMATOLÓGICOS } \\
\hline TRATAMENTO & \multicolumn{2}{|l|}{ TS 5} & \multicolumn{2}{|l|}{ TS 20} & US $(0-20)$ & \multicolumn{2}{|c|}{ US $(20-40)$} \\
\hline Cana crua & \multicolumn{2}{|l|}{$-0,0708$} & \multicolumn{2}{|l|}{$-0,0708$} & 0,2723 & \multicolumn{2}{|c|}{0,6950} \\
\hline Cana queimada & \multicolumn{2}{|l|}{$-0,3148$} & \multicolumn{2}{|l|}{$-0,3148$} & $-0,6167$ & \multicolumn{2}{|c|}{$-0,6784$} \\
\hline
\end{tabular}

* Nível de significância a $5 \%$ de probabilidade 


\subsection{Matéria seca de folhas (MSF)}

A evolução da matéria seca de folhas, ao longo do ano, apresentou-se mais uniforme no $2^{\underline{\underline{o}}}$ ano (Figura 8 ). No $1^{\underline{\underline{o}}}$ ano, houve um crescimento muito baixo até aproximadamente $120 \mathrm{DAC}$ e acelerando, rapidamente, até aproximadamente 250 dias.

A regressão não-linear permitiu a adaptação dos dados às seguintes equações (de Gompertz), com seus coeficientes de regressão:

$1^{\circ}$ ano - cana crua -

$$
\begin{aligned}
& \operatorname{MSF}\left(\mathrm{g} \cdot \mathrm{m}^{-2}\right)=1177,3531^{125,4111^{0,0264 x}} \\
& \left(\mathrm{R}^{2}=0,9871\right) \text {; }
\end{aligned}
$$

- cana queimada -

$$
\begin{aligned}
& \operatorname{MSF}\left(\mathrm{g} \cdot \mathrm{m}^{-2}\right)=1109,6892^{240,5015^{0,0316 x}} \\
& \left(\mathrm{R}^{2}=0,9700\right)
\end{aligned}
$$

$2^{\circ}$ ano - cana crua -

$$
\begin{aligned}
& \operatorname{MSF}\left(g \cdot m^{-2}\right)=1431,8763^{5,9684^{0,0120 x}} \\
& \left(R^{2}=0,9788\right)
\end{aligned}
$$

- cana queimada -

$$
\begin{aligned}
& \operatorname{MSF}\left(g \cdot m^{-2}\right)=1528,2043^{5,6030} 0,0118 x \\
& \left(R^{2}=0,9869\right) .
\end{aligned}
$$

Os dados não apresentaram diferenças significativas para matéria seca de folhas, no $1^{\circ}$ ano de amostragem. Contudo, no $2^{\circ}$ ano, houve diferenças aos 37 e 272 $\mathrm{DAC}$, tendo, na primeira data, a cana crua a ter os maiores valores e na segunda data, a cana queimada (Tabela 12).

As correlações da matéria seca de folhas com os indices biométricos e os fatores climatológicos, nas datas de diferenças significativas entre os tratamentos, estão explicitadas na Tabela 13. 

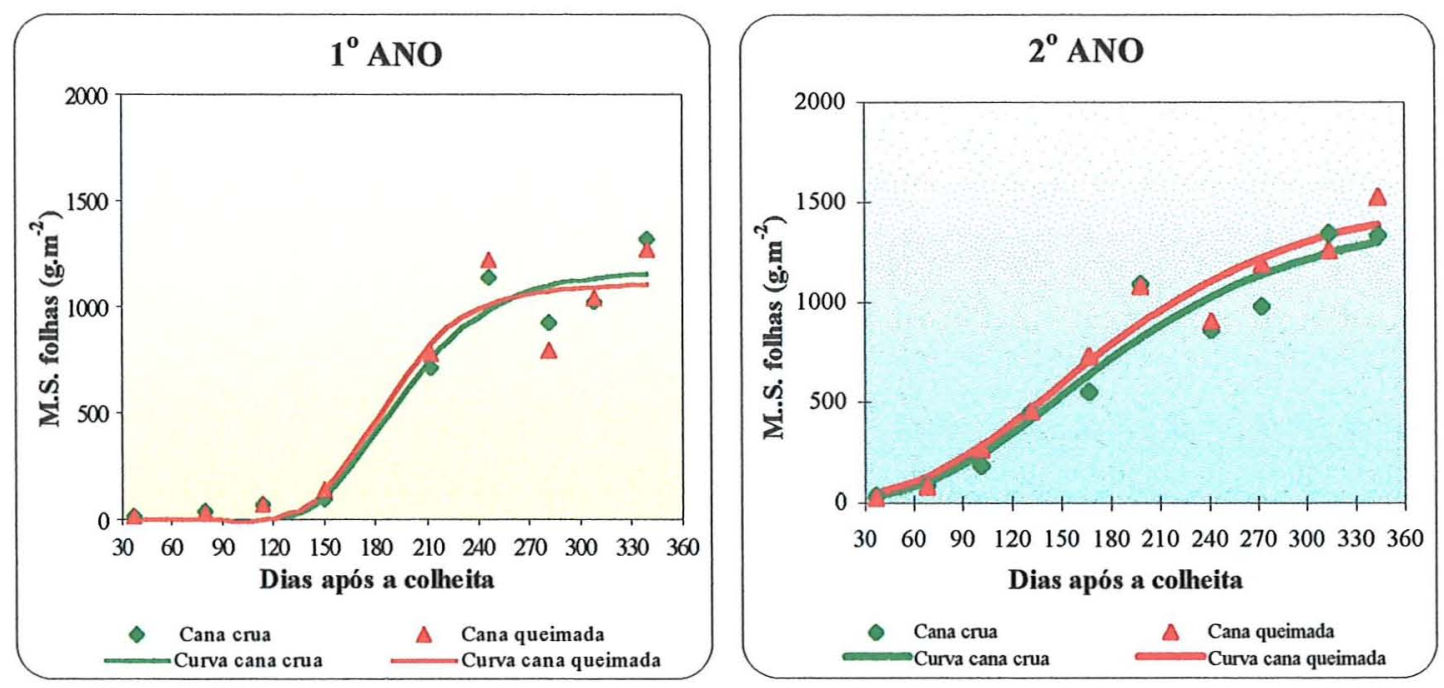

Figura 8 - Matéria seca de folhas $\left(\mathrm{g} \cdot \mathrm{m}^{-2}\right)$ no $1^{\mathrm{o}}$ e $2^{\underline{o}}$ ano de amostragem.

Tabela 12. Média dos tratamentos para matéria seca de folhas $\left(\mathrm{g} \cdot \mathrm{m}^{-2}\right)$, aos 37 e 272 DAC, no $2^{\circ}$ ano de amostragem.

\begin{tabular}{ccc}
\hline & \multicolumn{2}{c}{ DIAS APÓS A COLHEITA (DAC) } \\
\hline TRATAMENTO & 37 & 272 \\
\hline Cana crua & $36,2968 \mathrm{~A}$ & $981,8641 \mathrm{~B}$ \\
Cana queimada & $27,7781 \mathrm{~B}$ & $1190,6322 \mathrm{~A}$ \\
\hline F & $8,23 *$ & $7,61 *$ \\
C.V. & 13,11 & 9,85 \\
\hline
\end{tabular}

* Nível de significância a 5\% de probabilidade 
Tabela 13. Correlações da matéria seca de folhas com índices biométricos e parâmetros climatológicos, aos 37 e 272 DAC, no $2^{\underline{o}}$ ano de amostragem.

\begin{tabular}{|c|c|c|c|c|c|c|c|}
\hline 37 DAC & \multicolumn{7}{|c|}{ ÍNDICES BIOMÉTRICOS } \\
\hline TRATAMENTO & NP & NF & DIAM & ALT & MSC & MSR & IAF \\
\hline Cana crua & $-0,3595$ & 0,2617 & 0,7747 & 0,7095 & $0,9623^{*}$ & $-0,7689$ & 0,9899 \\
\hline Cana queimada & 0,3015 & 0,6363 & $-0,5222$ & 0,6259 & 0,9190 & $-0,2376$ & $0,9654^{*}$ \\
\hline 37 DAC & \multicolumn{7}{|c|}{ PARÂMETROS CLIMATOLÓGICOS } \\
\hline TRATAMENTO & \multicolumn{2}{|l|}{ TS 5} & \multicolumn{2}{|l|}{ TS 20} & US $(0-20)$ & \multicolumn{2}{|c|}{ US $(20-40)$} \\
\hline Cana crua & \multicolumn{2}{|l|}{$-0,7329$} & \multicolumn{2}{|l|}{$-0,7329$} & $-0,3777$ & \multicolumn{2}{|c|}{$-0,0155$} \\
\hline Cana queimada & \multicolumn{2}{|l|}{0,9045} & \multicolumn{2}{|l|}{0,9045} & 0,8118 & \multicolumn{2}{|c|}{0,7246} \\
\hline 272 DAC & \multicolumn{7}{|c|}{ ÍNDICES BIOMÉTRICOS } \\
\hline TRATAMENTO & NP & NF & DIAM & ALT & MSC & MSR & IAF \\
\hline Cana crua & 0,7893 & 0,2269 & $-0,7765$ & $-0,1926$ & 0,1577 & 0,6057 & 0,9643 \\
\hline \multirow[t]{2}{*}{ Cana queimada } & 0,9171 & $-0,3314$ & 0,6688 & 0,0432 & 0,8534 & 0,4374 & 0,2923 \\
\hline & \multicolumn{7}{|c|}{ PARÂMETROS CLIMATOLÓGICOS } \\
\hline TRATAMENTO & \multicolumn{2}{|l|}{ TS 5} & \multicolumn{2}{|l|}{ TS 20} & US $(0-20)$ & \multicolumn{2}{|c|}{ US $(20-40)$} \\
\hline Cana crua & \multicolumn{2}{|l|}{$-0,1358$} & \multicolumn{2}{|l|}{0,1358} & $-0,8775$ & \multicolumn{2}{|c|}{$-0,4657$} \\
\hline Cana queimada & \multicolumn{2}{|c|}{$-0,3329$} & \multicolumn{2}{|l|}{$-0,3329$} & $-0,9360$ & \multicolumn{2}{|c|}{$-0,8133$} \\
\hline
\end{tabular}

* Nivel de significância a $5 \%$ de probabilidade

\subsection{Matéria seca da parte aérea (MSPA)}

A matéria seca da parte aérea apresentou-se maior no $1^{\circ}$ ano que no $2^{\circ}$ ano. As variações em sua composição estão demonstradas na Figura 11, que é composta por gráficos representativos de cana crua e cana queimada no $1^{\underline{0}}$ e $2^{\circ}$ anos de amostragem.

No $1^{\underline{0}}$ ano, a matéria seca de colmos ultrapassou a matéria seca de folhas, em termos percentuais, na composição da matéria seca da parte aérea, aos 150 DAC para cana crua e para cana queimada. No $2^{\underline{\underline{a}}}$ ano, essa mudança ocorreu também próxima dos 150 DAC (aos 167 DAC). 

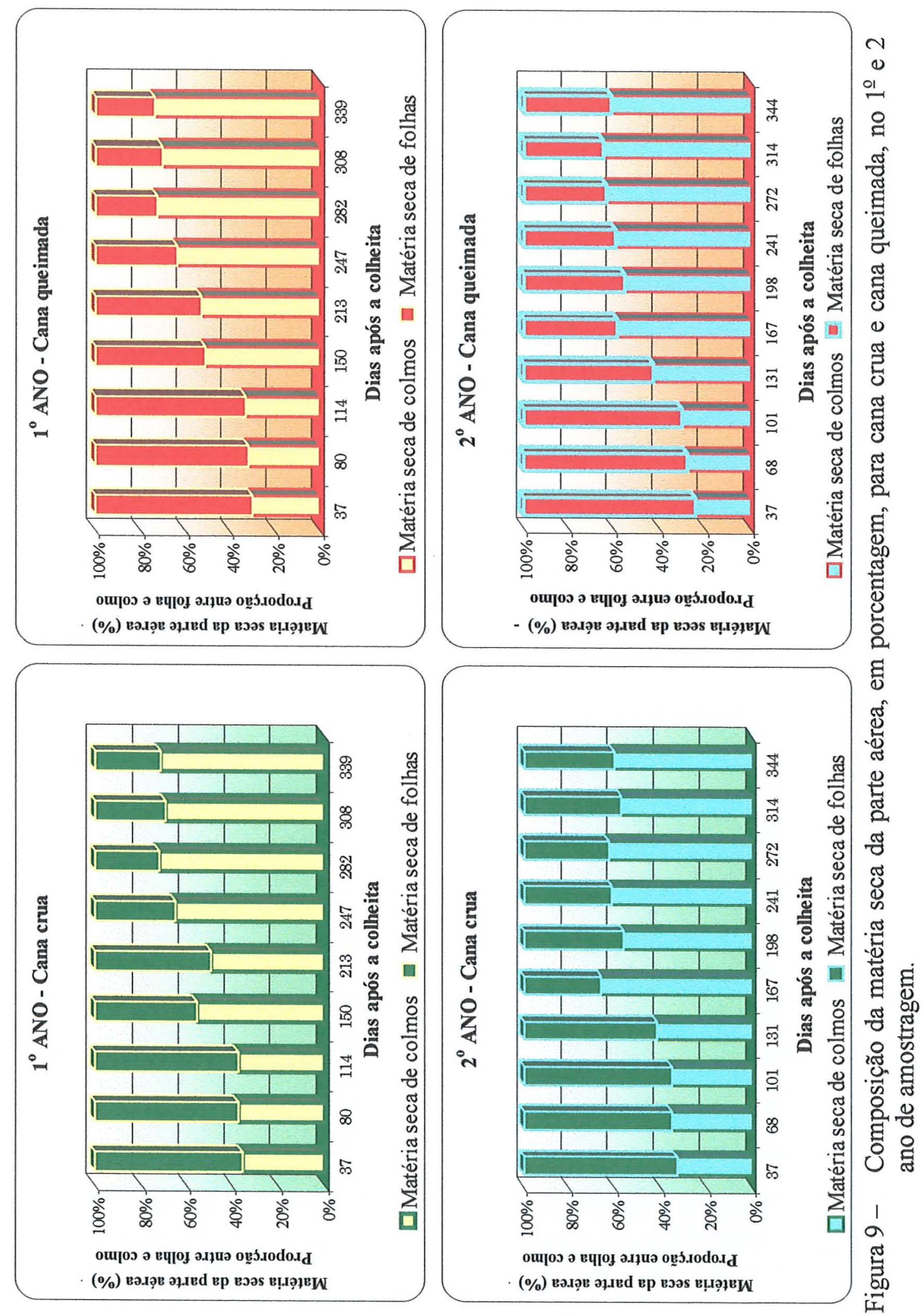


\section{8 Índice de área foliar (IAF)}

A seguir, relacionam-se as equações de Gompertz e os $\mathrm{R}^{2}$ obtidos a partir dos dados de IAF:

$1^{\circ}$ ano - cana crua -

$$
\begin{aligned}
& \mathrm{IAF}=8,4673^{5527,9126^{0,0527 x}} \\
& \left(\mathrm{R}^{2}=0,9560\right) \text {; }
\end{aligned}
$$

- cana queimada -

$$
\begin{aligned}
& I A F=9,0995^{3697,9396^{0,0499 x}} \\
& \left(\mathrm{R}^{2}=0,9371\right) \text {; }
\end{aligned}
$$

$2^{\circ}$ ano - cana crua -

$$
\begin{aligned}
& \mathrm{IAF}=8,2926^{16,1612^{0,0235 x}} \\
& \left(\mathrm{R}^{2}=0,9573\right)
\end{aligned}
$$

- cana queimada -

$$
\begin{aligned}
& \mathrm{IAF}=9,1452^{8,4539^{0,0186 x}} \\
& \left(\mathrm{R}^{2}=0,9844\right)
\end{aligned}
$$

O IAF apresentou diferenças significativas somente aos 241 DAC do $2^{\underline{0}}$ ano (Tabela 14) e as correlações apresentadas, nesta data de amostragem, estão na tabela 15.

Os valores máximos de IAF encontrados no $1^{\circ}$ ano foram observados aos 247 DAC: 11,5611 e 12,5526 , respectivamente para cana crua e cana queimada. No $2^{\circ}$ ano, para cana crua, foi aos $198 \mathrm{DAC}$, com o valor de 9,8934 e, para cana queimada, 10,2457 aos 344 DAC.

O IAF médio das amostragens, no $1^{\underline{0}}$ ano, foi de 4,8211 para cana crua e 5,1689 para cana queimada; já no $2^{\underline{o}}$ ano, foi de 5,1986 e 5,6374 , respectivamente. 

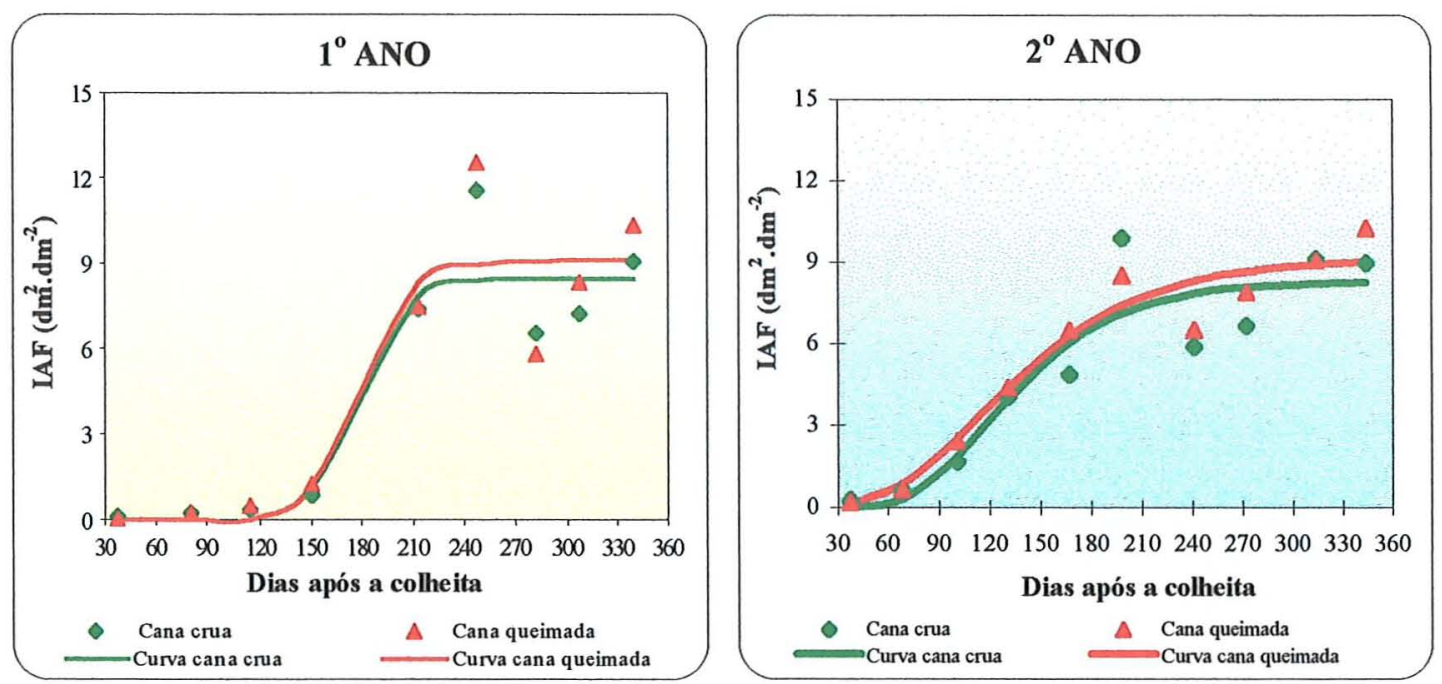

Figura 10 - Índice de área foliar $\left(\mathrm{dm}^{2} \cdot \mathrm{dm}^{-2}\right)$ no $1^{\underline{0}}$ e $2^{\underline{0}}$ ano de amostragem.

Tabela 14. Média dos tratamentos para IAF, aos 241 DAC, no $2^{\circ}$ ano de amostragem.

\begin{tabular}{cc}
\hline & DIAS APÓS A COLHEITA (DAC) \\
\hline TRATAMENTO & 241 \\
\hline Cana crua & $5,8951 \mathrm{~A}$ \\
Cana queimada & $7,9066 \mathrm{~B}$ \\
\hline F & $18,39 * *$ \\
C.V. (\%) & 9,61 \\
\hline
\end{tabular}

** Nível de significância a 1\% de probabilidade 
Tabela 15. Correlações do IAF com índices biométricos e parâmetros climatológicos, aos 241 DAC, no $2^{\circ}$ ano de amostragem.

\begin{tabular}{cccccccc}
\hline \multicolumn{7}{c}{ ÍNDICES BIOMÉTRICOS } \\
\hline TRATAMENTO & NP & NF & DIAM & ALT & MSC & MSF & MSR \\
\hline Cana crua & 0,0879 & $-0,0357$ & 0,0075 & $-0,3464$ & 0,8517 & 0,3213 & $-0,9140^{*}$ \\
Cana queimada & 0,5875 & 0,9002 & 0,8657 & $-0,8859$ & 0,0426 & 0,9027 & $-0,5648$ \\
\hline \multicolumn{7}{c}{ PARÂMETROS CLIMATOLÓGICOS } \\
\hline TRATAMENTO & TS 5 & TS 20 & US $(0-20)$ & US (20-40) \\
\hline Cana crua & 0,2858 & 0,2858 & 0,6492 & 0,2058 \\
Cana queimada & $-0,6130$ & 0,6130 & 0,6643 & 0,6904 \\
\hline
\end{tabular}

* Nivel de significância a $5 \%$ de probabilidade

\subsection{Matéria seca de colmos na colheita (MSCC)}

A matéria seca de colmos na colheita vai diminuindo à medida que aumenta 0 corte, na cana crua. Em cana queimada, praticamente não houve maior alteração.

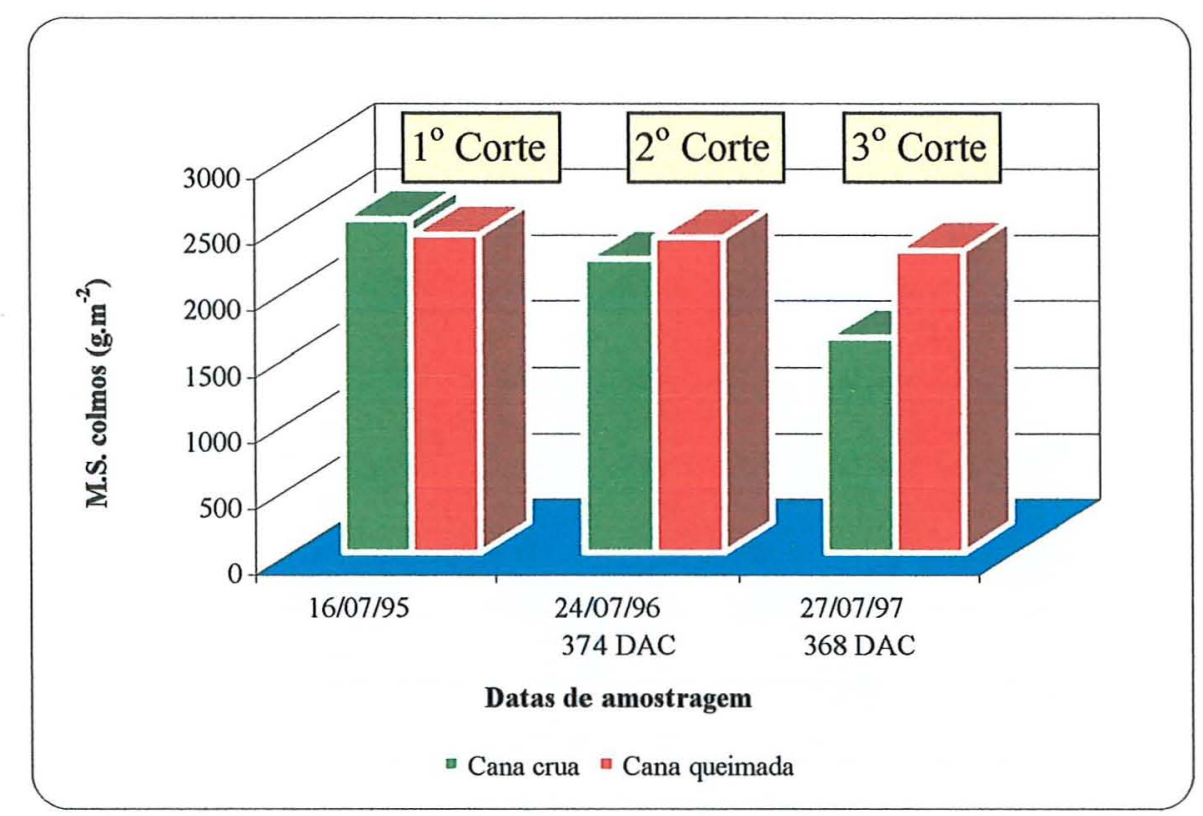

Figura 11 - Matéria seca de colmos $\left(\mathrm{g} \cdot \mathrm{m}^{-2}\right)$ na colheita nos três cortes. 


\subsection{Matéria seca de raízes (MSR)}

No primeiro e segundo ano, as variações na matéria seca de raízes $\left(\mathrm{g} \cdot \mathrm{m}^{-3}\right)$ não apresentaram um padrão marcante de crescimento, embora não se tenham distinguido raízes vivas de raízes mortas (Figura 10).
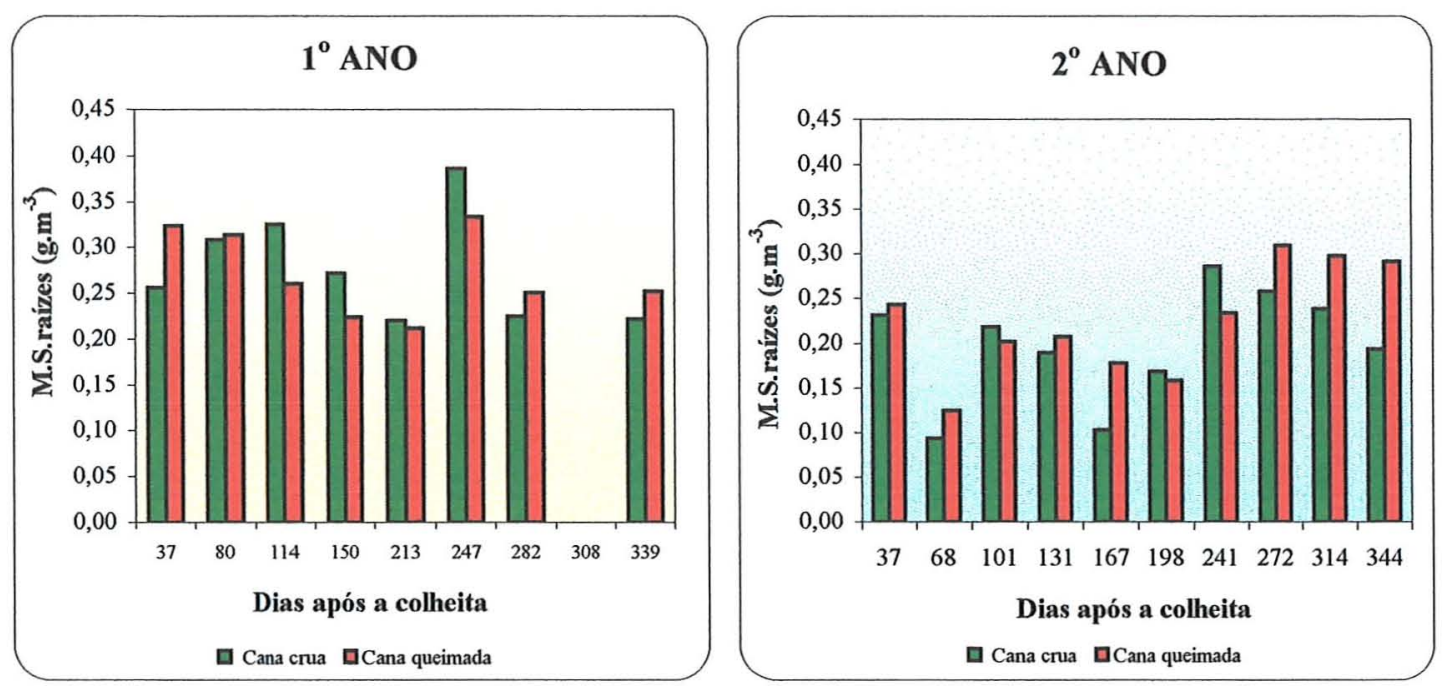

Figura 12 - Matéria seca de raízes $\left(\mathrm{g} \cdot \mathrm{m}^{-3}\right)$ no $1^{\underline{o}}$ e $2^{\underline{o}}$ ano de amostragem.

As diferenças significativas entre as médias dos tratamentos ocorreram apenas no $2^{\circ}$ ano, aos 68,167 e 344 DAC e a cana queimada foi o tratamento que mostrou-se com valores maiores nas três datas (Tabela 16).

Tabela 16. Média dos tratamentos para matéria seca de raízes $\left(\mathrm{g} \cdot \mathrm{m}^{-3}\right)$, aos 68,167 e 344 DAC, no $2^{\underline{o}}$ ano de amostragem.

\begin{tabular}{cccc}
\hline & \multicolumn{3}{c}{ DIAS APÓS A COLHEITA (DAC) } \\
\hline TRATAMENTO & 68 & 167 & 344 \\
\hline Cana crua & $0,0939 \mathrm{~A}$ & $0,1032 \mathrm{~B}$ & $0,1936 \mathrm{~B}$ \\
Cana queimada & $0,1247 \mathrm{~B}$ & $0,1776 \mathrm{~A}$ & $0,2916 \mathrm{~A}$ \\
\hline F & $27,76^{* *}$ & $7,31^{*}$ & $6,85^{*}$ \\
C.V. & 7,55 & 27,71 & 21,82 \\
\hline
\end{tabular}

* Nível de significância a $5 \%$ de probabilidade 
As correlações obtidas através da análise estatística para as datas, onde houve diferenças significativas, são apresentadas na tabela 17.

As médias de matéria seca de raízes no $1^{\circ}$ ano foram: $0,2770 \mathrm{~g} \cdot \mathrm{m}^{-3}$ para cana crua e 0,2713 g.m $\mathrm{m}^{-3}$ para cana queimada. No $2^{\circ}$ ano, as médias foram: 0,1981 e 0,2246 g. $\mathrm{m}^{-3}$, respectivamente, para cana crua e cana queimada.

Tabela 17. Correlações da matéria seca de raizes com índices biométricos e parâmetros climatológicos aos 68,167 e $344 \mathrm{DAC}$, no $2^{\circ}$ ano de amostragem.

\begin{tabular}{|c|c|c|c|c|c|c|c|}
\hline \multirow{2}{*}{$\frac{\text { 68 DIAS }}{\text { TRAT AMENTO }}$} & \multicolumn{7}{|c|}{ ÍNDICES BIOMÉTRICOS } \\
\hline & NP & NF & DIAM & ALT & MSC & MSF & IAF \\
\hline Cana crua & 0,7115 & $-0,2137$ & 0,3143 & $-0,7435$ & $-0,3021$ & $-0,3636$ & $-0,2728$ \\
\hline \multirow[t]{2}{*}{ Cana queimada } & 0,7946 & $-0,6904$ & $-0,0201$ & 0,4903 & 0,4152 & 0,3056 & 0,1609 \\
\hline & \multicolumn{7}{|c|}{ PARÂMETROS CLIMATOLÓGICOS } \\
\hline TRATAMENTO & \multicolumn{2}{|l|}{ TS 5} & \multicolumn{2}{|c|}{ TS 20} & US $(0-20)$ & \multicolumn{2}{|c|}{ US $(20-40)$} \\
\hline Cana crua & \multicolumn{2}{|l|}{$-0,2137$} & \multicolumn{2}{|l|}{02137} & 0,8837 & \multicolumn{2}{|c|}{0,8064} \\
\hline Cana queimada & \multicolumn{2}{|l|}{$-0,2573$} & \multicolumn{2}{|l|}{$-0,2573$} & $-0,7839$ & \multicolumn{2}{|c|}{$-0,9460$} \\
\hline 167 DIAS & \multicolumn{7}{|c|}{ ÍNDICES BIOMÉTRICOS } \\
\hline TRATAMENTO & NP & NF & DIAM & ALT & MSC & MSF & IAF \\
\hline Cana crua & 0,3055 & 0,2242 & $-0,1762$ & $-0,8556$ & 0,2921 & $-0,3251$ & $-0,5716$ \\
\hline \multirow[t]{2}{*}{ Cana queimada } & 0,5174 & $-0,5380$ & $-0,7583$ & -0.2202 & $-0,09581$ & 0,1960 & $0,9808^{*}$ \\
\hline & \multicolumn{7}{|c|}{ PARÀMETROS CLIMATOLOGICOS } \\
\hline TRATAMENTO & \multicolumn{2}{|l|}{ TS 5} & \multicolumn{2}{|l|}{ TS 20} & US $(0-20)$ & \multicolumn{2}{|c|}{ US $(20-40)$} \\
\hline Cana crua & \multicolumn{2}{|c|}{$-0,4979$} & \multicolumn{2}{|l|}{$-0,4979$} & 0,8901 & \multicolumn{2}{|c|}{0,9387} \\
\hline Cana queimada & \multicolumn{2}{|c|}{0,1875} & \multicolumn{2}{|l|}{0,1875} & $-0,7362$ & \multicolumn{2}{|c|}{0,0090} \\
\hline 344 DIAS & \multicolumn{7}{|c|}{ ÍNDICES BIOMÉTRICOS } \\
\hline TRATAMENTO & NP & NF & DIAM & ALT & MSC & MSF & IAF \\
\hline Cana crua & 0,4403 & 0,0731 & $-0,0002$ & 0,4828 & 0,2679 & 0,0456 & $-0,1147$ \\
\hline \multirow[t]{2}{*}{ Cana queimada } & 0,8193 & 0,7834 & 0,6914 & $-0,6861$ & 0.8150 & 0,4006 & 0,4451 \\
\hline & \multicolumn{7}{|c|}{ PARÂMETROS CLIMATOLÓGICOS } \\
\hline TRATAMENTO & \multicolumn{2}{|l|}{ TS 5} & \multicolumn{2}{|c|}{ TS 20} & US $(0-20)$ & \multicolumn{2}{|c|}{ US $(20-40)$} \\
\hline Cana crua & $-0,050$ & & 0,0509 & & $0,9905^{*}$ & & 9047 \\
\hline Cana queimada & 0,1260 & & $-0,1260$ & & 0,4113 & & 5144 \\
\hline
\end{tabular}

* Nivel de significância a $5 \%$ de probabilidade 


\subsection{Perfil de raízes (PR)}

A maior porcentagem de raizes presentes no solo encontra-se nas camadas mais superficiais, para os dois anos de amostragem. No $1^{\underline{9}}$ ano, houve diferença significativa entre a quantidade de matéria seca de raizes em g.m ${ }^{-3}$ de cana crua e a de cana queimada nas 5 profundidades avaliadas, enquanto que, em termos de porcentagem, houve diferenças na última camada. No $2^{\circ}$ ano, somente encontrou-se diferenças significativas no perfil $60-80 \mathrm{~cm}$, em termos de g.m $\mathrm{m}^{-3}$ e porcentagem. As tabelas 18 e 19 mostram esses valores.

Tabela 18. Comparação entre as média dos tratamentos para matéria seca de raizes em g. $\mathrm{m}^{-3} \mathrm{e}$ em porcentagem, em 5 profundidades de solo, no $1^{\mathrm{o}}$ ano de amostragem.

\begin{tabular}{|c|c|c|c|c|}
\hline \multicolumn{5}{|c|}{ MEDIA EM g.m ${ }^{-3}$} \\
\hline \multicolumn{5}{|c|}{ TRATAMENTOS } \\
\hline PROFUNDIDADE & Cana crua & Cana queimada & $F$ & $\mathrm{CV}$ \\
\hline $0-20 \mathrm{~cm}$ & $16,8941 \mathrm{~A}$ & $13,1191 \mathrm{~B}$ & $6,15 *$ & 14,34 \\
\hline $20-40 \mathrm{~cm}$ & $9,2281 \mathrm{~A}$ & $7,3915 \mathrm{~B}$ & $12,92 *$ & 8,70 \\
\hline $40-60 \mathrm{~cm}$ & $5,3706 \mathrm{~A}$ & $3,3875 \mathrm{~B}$ & $11,76^{*}$ & 18,68 \\
\hline $60-80 \mathrm{~cm}$ & $4,3309 \mathrm{~A}$ & $2,4409 \mathrm{~B}$ & $39,11^{* *}$ & 12,62 \\
\hline $80-100 \mathrm{~cm}$ & $3,7650 \mathrm{~A}$ & $2,0750 \mathrm{~B}$ & $89,28 * *$ & 8,66 \\
\hline \multicolumn{5}{|c|}{ MEDIA EM \% } \\
\hline \multicolumn{5}{|c|}{ TRATAMENTOS } \\
\hline PROFUNDIDADE & Cana crua & Cana queimada & $\mathrm{F}$ & $\mathrm{CV}$ \\
\hline $0-20 \mathrm{~cm}$ & $43,00 \mathrm{~A}$ & $42,65 \mathrm{~A}$ & 0,70 & 12,74 \\
\hline $20-40 \mathrm{~cm}$ & $23,32 \mathrm{~A}$ & $26,04 \mathrm{~A}$ & 2,71 & 9,46 \\
\hline $40-60 \mathrm{~cm}$ & $13,56 \mathrm{~A}$ & $12,01 \mathrm{~A}$ & 0,66 & 21,07 \\
\hline $60-80 \mathrm{~cm}$ & $10,95 \mathrm{~A}$ & $8,64 \mathrm{~A}$ & 3,94 & 16,85 \\
\hline $80-100 \mathrm{~cm}$ & $9,52 \mathrm{~A}$ & $7,32 \mathrm{~B}$ & $12,48 *$ & 10,48 \\
\hline
\end{tabular}

* Nivel de significância a $5 \%$ de probabilidade

** Nivel de significância a l\% de probabilidade 
Tabela 19. Comparação entre as médias dos tratamentos para matéria seca de raízes em g. $\mathrm{m}^{-3}$ e em porcentagem, em 5 profundidades de solo, no $2^{\mathrm{o}}$ ano de amostragem.

\begin{tabular}{lcccc}
\hline \multicolumn{5}{c}{ MEDIA EM g.m ${ }^{-3}$} \\
\hline \multicolumn{5}{c}{ TRATAMENTOS } \\
\hline PROFUNDIDADE & Cana crua & Cana queimada & $\mathrm{F}$ & $\mathrm{CV}$ \\
\hline $0-20 \mathrm{~cm}$ & $9,3600 \mathrm{~A}$ & $9,2600 \mathrm{~A}$ & 0,10 & 16,09 \\
$20-40 \mathrm{~cm}$ & $5,3270 \mathrm{~A}$ & $5,8775 \mathrm{~A}$ & 1,20 & 12,71 \\
$40-60 \mathrm{~cm}$ & $2,8963 \mathrm{~A}$ & $3,2618 \mathrm{~A}$ & 1,64 & 13,13 \\
$60-80 \mathrm{~cm}$ & $1,8495 \mathrm{~B}$ & $2,3485 \mathrm{~A}$ & $17,01^{* *}$ & 8,15 \\
$80-100 \mathrm{~cm}$ & $1,4254 \mathrm{~A}$ & $1,7275 \mathrm{~A}$ & 2,40 & 17,48 \\
\hline & & MEDIA EM \% & & \\
\hline TROFUNDIDADE & Cana crua & Cana queimada & $\mathrm{F}$ & $\mathrm{CV}$ \\
\hline $0-20 \mathrm{~cm}$ & $43,16 \mathrm{~A}$ & $41,65 \mathrm{~A}$ & 0,78 & 5,70 \\
$20-40 \mathrm{~cm}$ & $27,25 \mathrm{~A}$ & $25,85 \mathrm{~A}$ & 1,06 & 7,26 \\
$40-60 \mathrm{~cm}$ & $13,21 \mathrm{~A}$ & $14,41 \mathrm{~A}$ & 1,92 & 8,91 \\
$60-80 \mathrm{~cm}$ & $8,77 \mathrm{~B}$ & $10,38 \mathrm{~A}$ & $21,13^{* *}$ & 5,18 \\
$80-100 \mathrm{~cm}$ & $7,61 \mathrm{~A}$ & $7,70 \mathrm{~A}$ & 0,02 & 12,41 \\
\hline
\end{tabular}

** Nivel de significância a $1 \%$ de probabilidade

Para melhor entendimento de como se distribui o sistema radicular no perfil de solo mais próximo da cana-de-açúcar, as figuras a seguir representam a quantidade proporcional de raizes nos perfis em relação ao quadrante com o máximo de raiz encontrado, considerado como $100 \%$, no $1^{\circ}$ e $2^{\circ}$ ano de amostragem.

A escala de cores a seguir representa a quantidade de raizes em cada quadrante e as letras e os números, utilizados para indicar o quadrante, conforme apresentado na Figura 2. As cores são utilizadas a partir do quadrante, onde houve maior presença de raiz. 
As profundidades são as seguintes: A - 0-20 cm; B - 20-30 cm; C - 40-60 $\mathrm{cm} ; \mathrm{D}-60-80 \mathrm{~cm}$ e $\mathrm{E}-80-100 \mathrm{~cm}$.

As distâncias do eixo principal da touceira são: 1 - 20-40 $\mathrm{cm}$ à esquerda; $2-0-20 \mathrm{~cm}$ à direita; 3 - eixo da touceira $(20 \mathrm{~cm}) ; 4-0-20 \mathrm{~cm}$ à direita e $5-20-40 \mathrm{~cm}$ à direita.
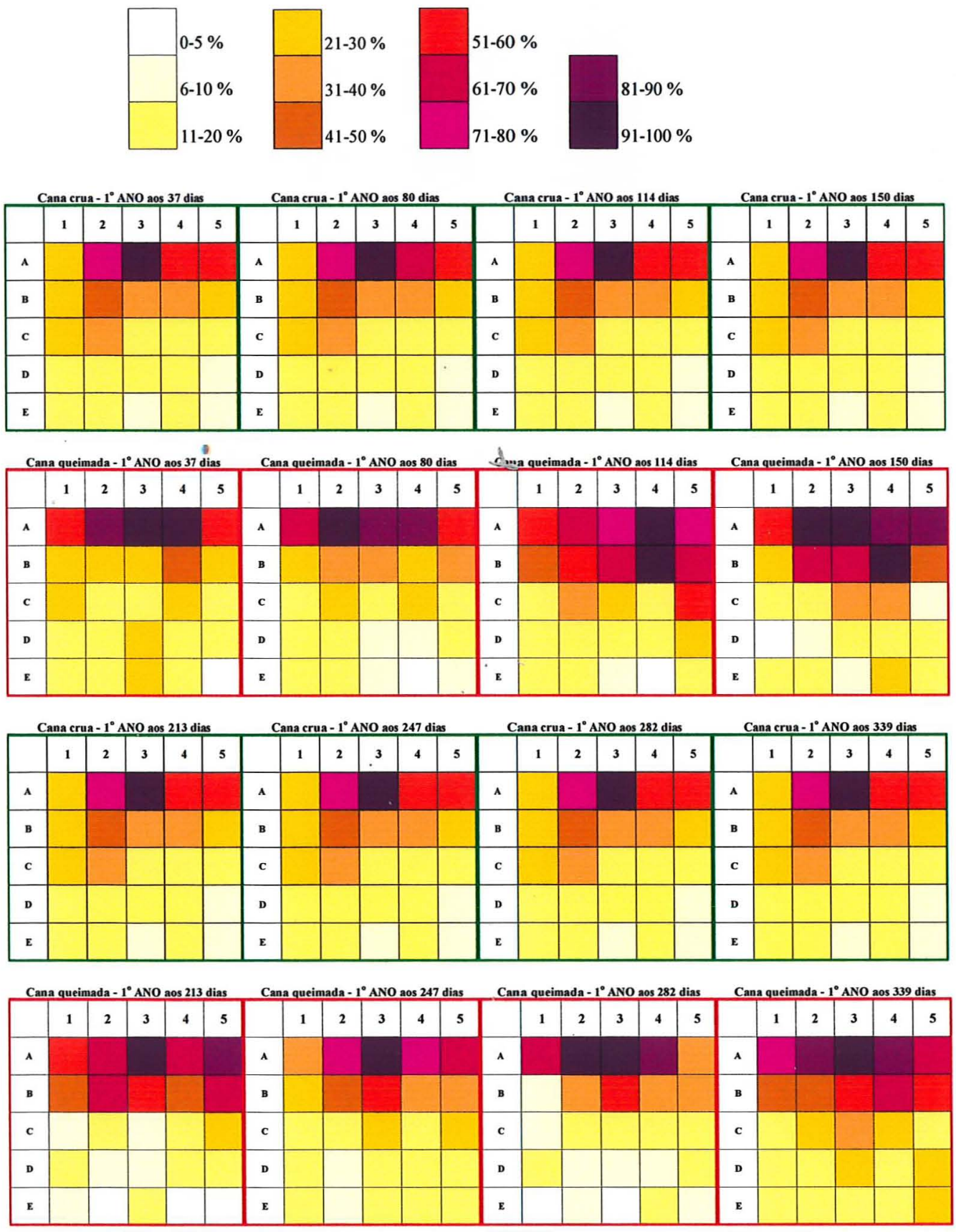

Figura 13 - Perfil de raízes no $1^{\circ}$ ano de amostragem. 

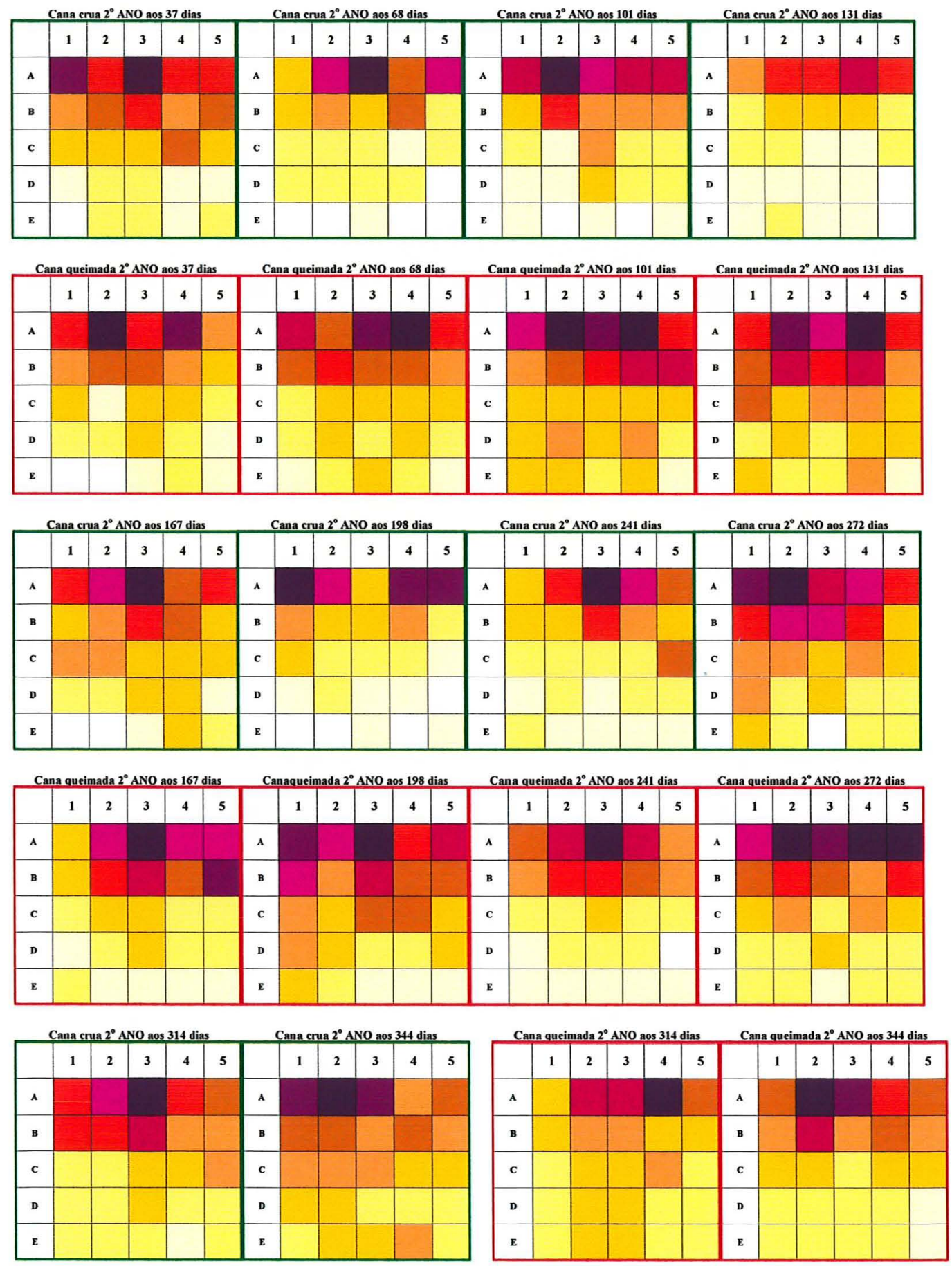

Figura 14 - Perfil de raízes no $2^{\circ}$ ano de amostragem. 


\subsection{Levantamento de população de cigarrinhas (Mahanarva fimbriolata)}

* A presença de ninfas de cigarrinhas foi constatada com maior intensidade a partir do mês de novembro, nos dois anos de amostragem, sendo maior em cana crua que em cana queimada.

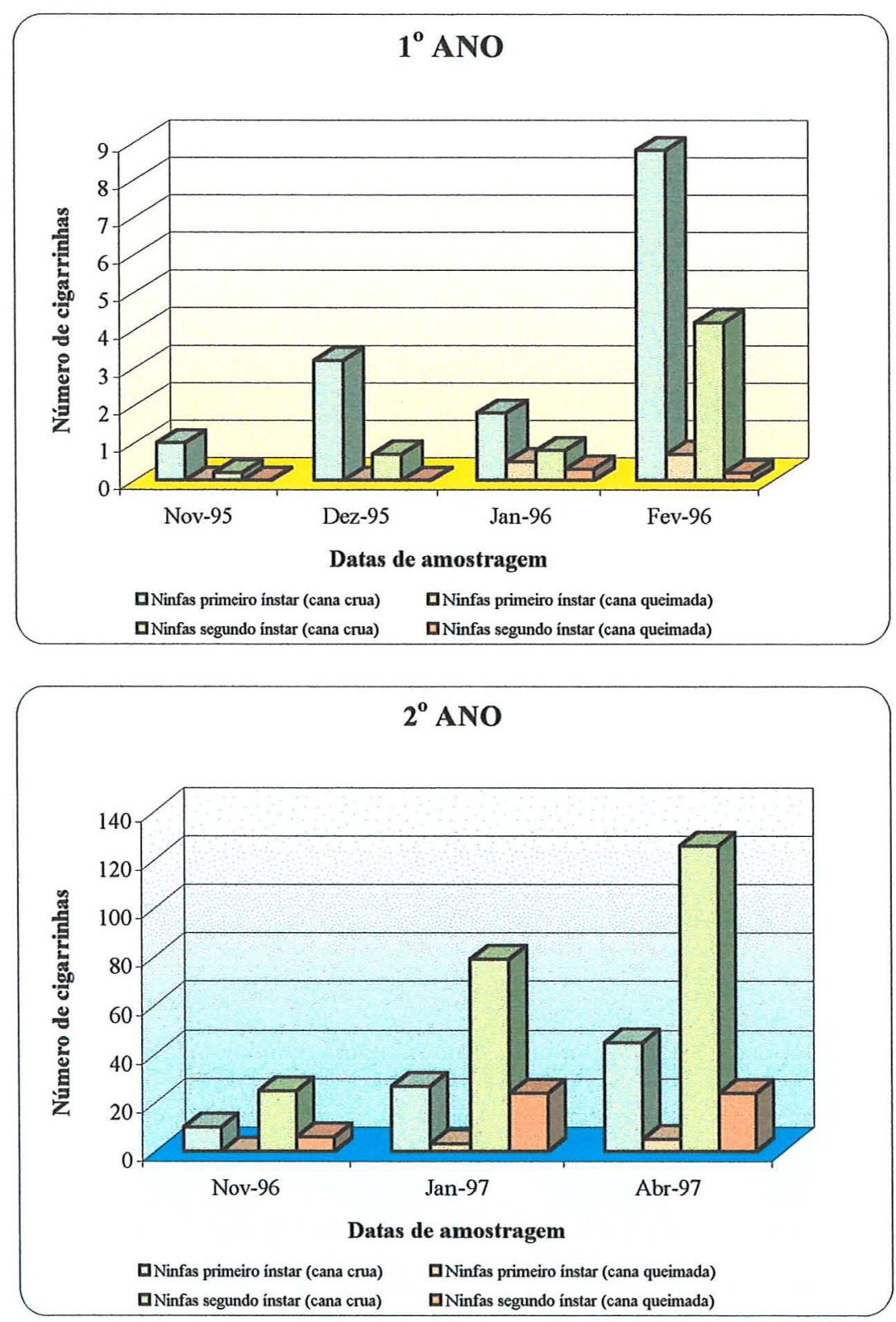

Figura 15 - Levantamento da população de cigarrinhas no $1^{0} \underline{0}$ e $2^{\underline{0}}$ ano de amostragem. 


\subsection{Condições ambientais frente aos índices biométricos}

\subsubsection{Temperatura do ar em graus dia}

As curvas de acúmulo de graus-dia foram obtidas a partir das seguintes equações e coeficientes de regressão:

$1^{0}$ ano -

$\operatorname{TEMP}\left({ }^{\mathrm{O}} \mathrm{C} \cdot \mathrm{dia}^{-1}\right)=2022,1906^{4,3749} 9^{0,0103 \mathrm{x}}$

$\left(\mathrm{R}^{2}=0,9992\right)$;

$2^{\underline{o}}$ ano -

$$
\begin{aligned}
& \operatorname{TEMP}\left({ }^{\mathrm{O}} \mathrm{C} \cdot \mathrm{dia}^{-1}\right)=2022,1906^{4,3749} 0,0103 \mathrm{x} \\
& \left(\mathrm{R}^{2}=0,9961\right) .
\end{aligned}
$$
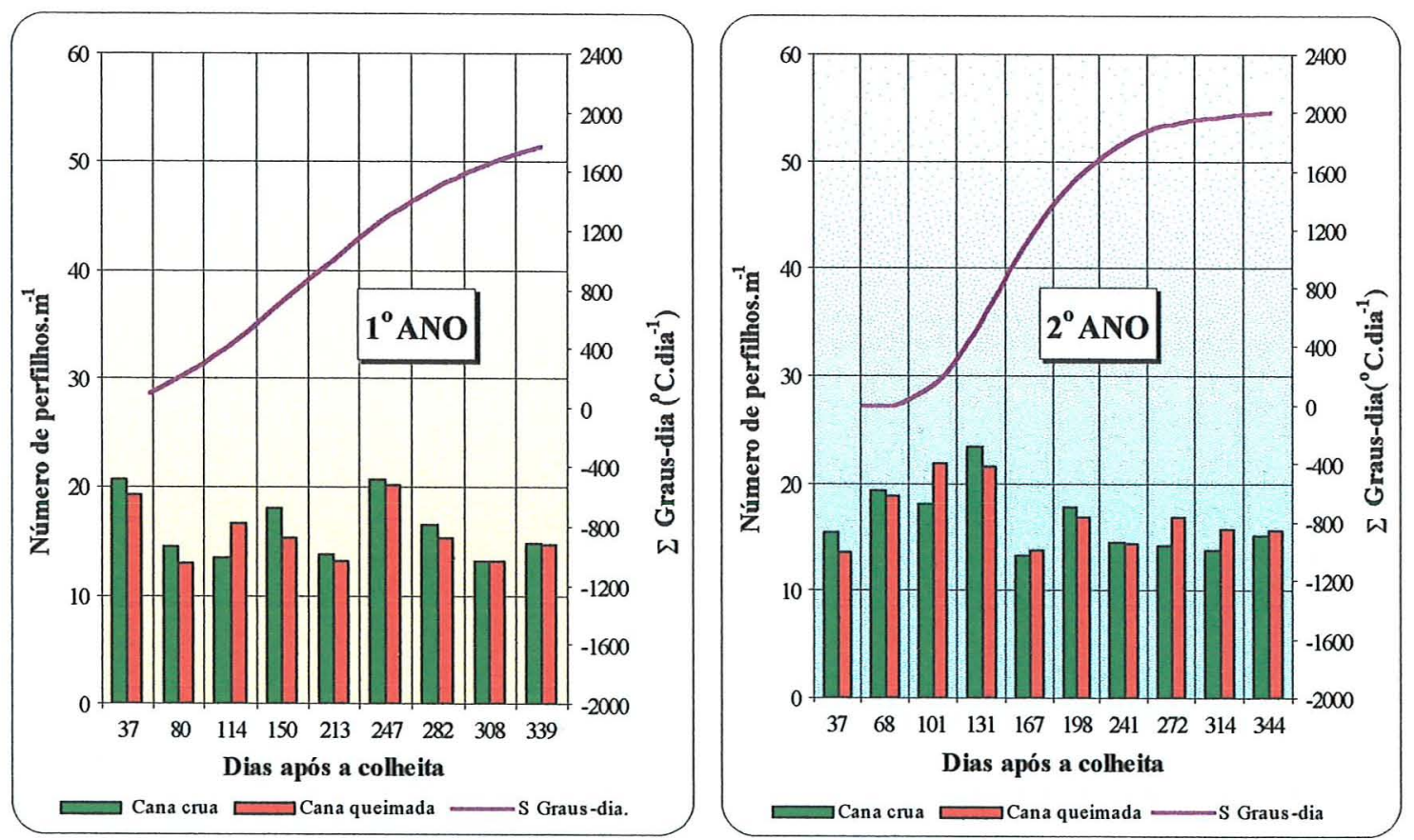

Figura 16 - Acúmulo de graus dia $\left({ }^{\circ} \mathrm{C} \cdot \mathrm{dia}^{-1}\right)$ frente ao número de perfilhos $/ \mathrm{m}$, no $1^{\mathrm{o}} \mathrm{e}$ $2^{\underline{0}}$ ano de amostragem. 

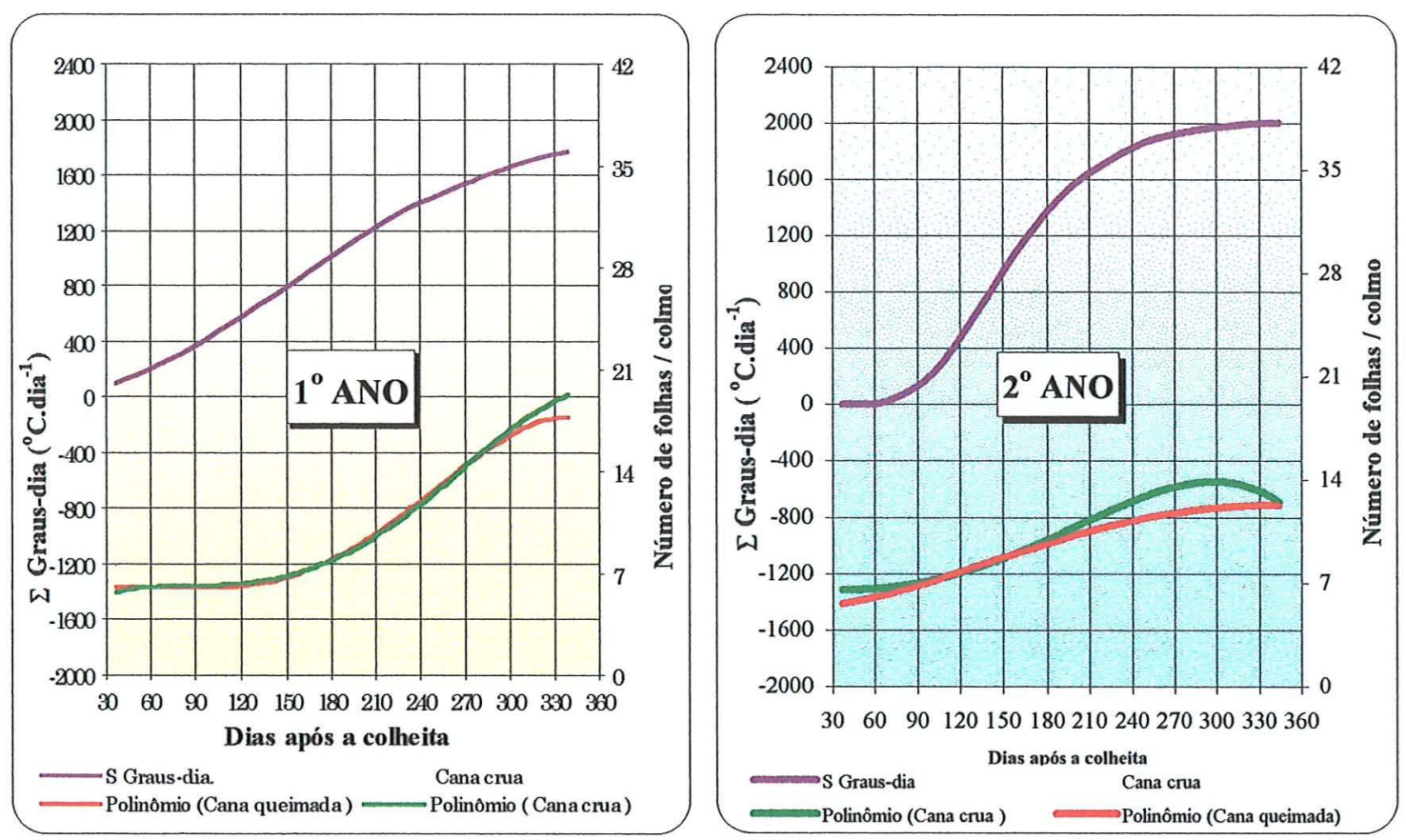

Figura 17 - Acúmulo de graus dia $\left({ }^{\circ} \mathrm{C} \cdot \mathrm{dia}^{-1}\right)$ frente ao número de folhas / colmo, no $1^{\varrho} \mathrm{e}$ $2^{\circ}$ ano de amostragem.
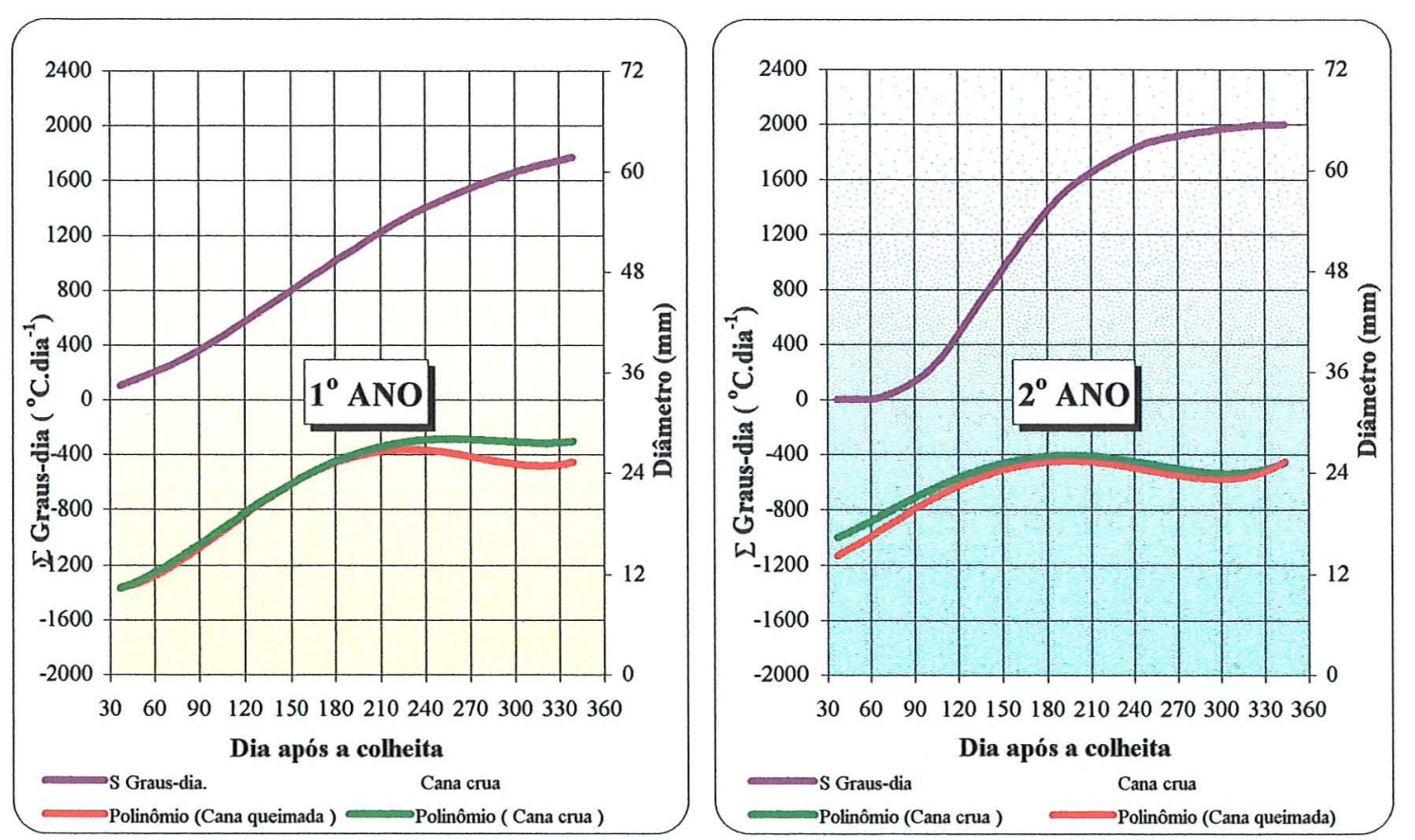

Figura 18 - Acúmulo de graus dia $\left({ }^{\circ} \mathrm{C} \cdot \mathrm{dia}^{-1}\right)$ frente ao diâmetro de colmos, no $1^{\underline{0}}$ e $2^{\underline{o}}$ ano de amostragem. 

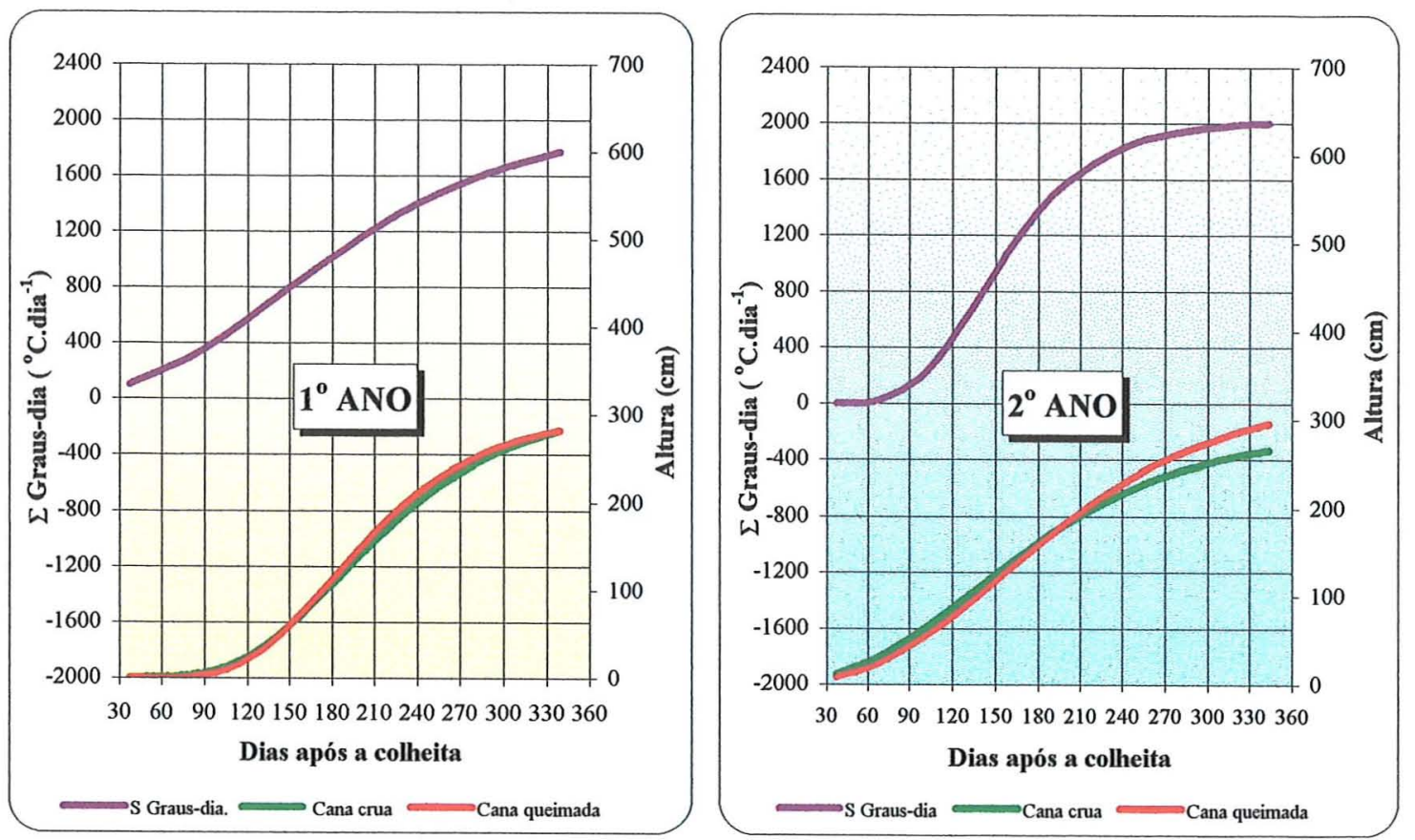

Figura 19 - Acúmulo de graus dia $\left({ }^{\circ} \mathrm{C} \cdot \mathrm{dia}^{-1}\right)$ frente à altura de plantas, no $1^{\circ}$ e $2^{\circ}$ ano de amostragem.
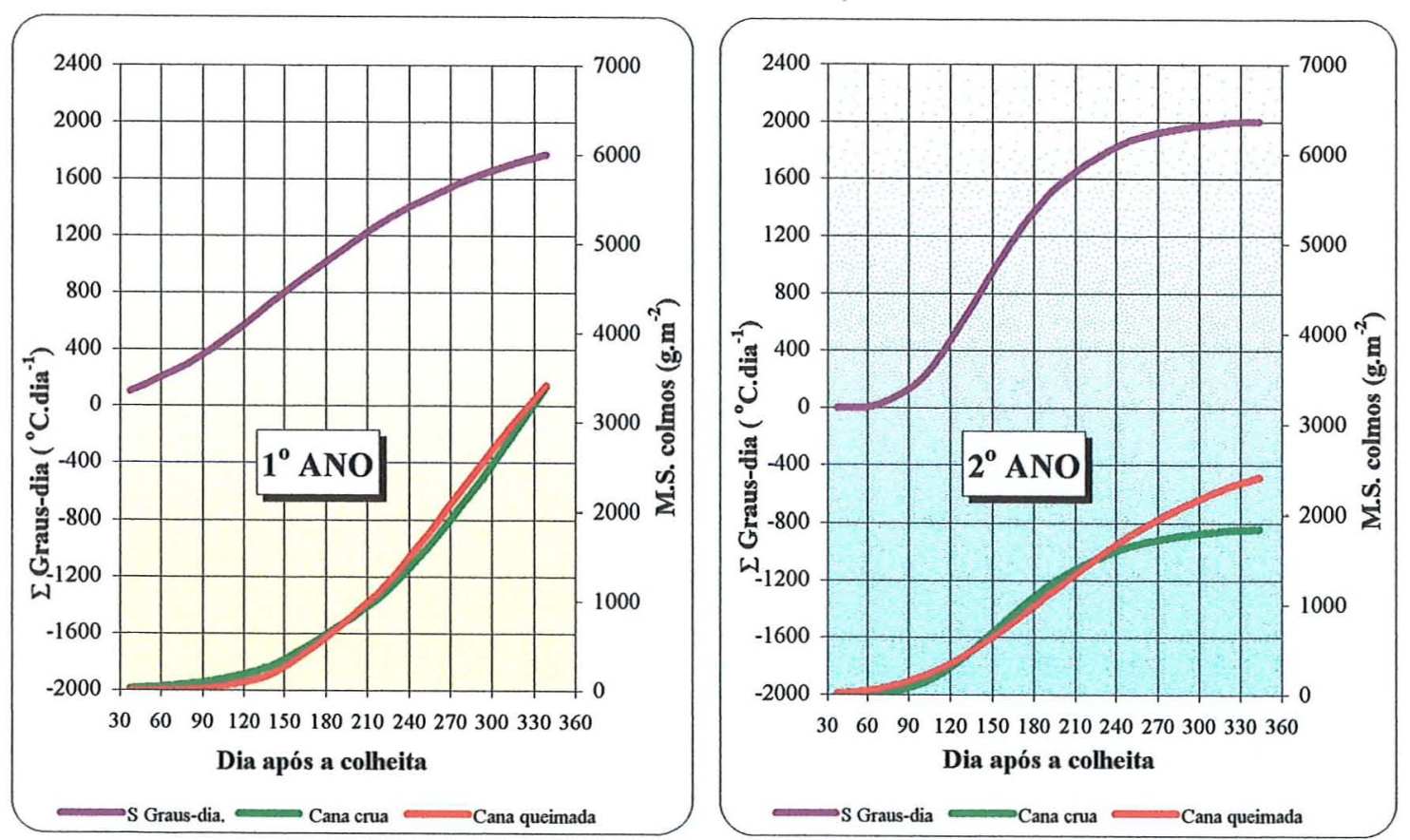

Figura 20 - Acúmulo de graus dia $\left({ }^{\circ} \mathrm{C} \cdot \mathrm{dia}^{-1}\right)$ frente à matéria seca de colmos, no $1^{\mathrm{o}}$ e $2^{\mathrm{o}}$ ano de amostragem. 

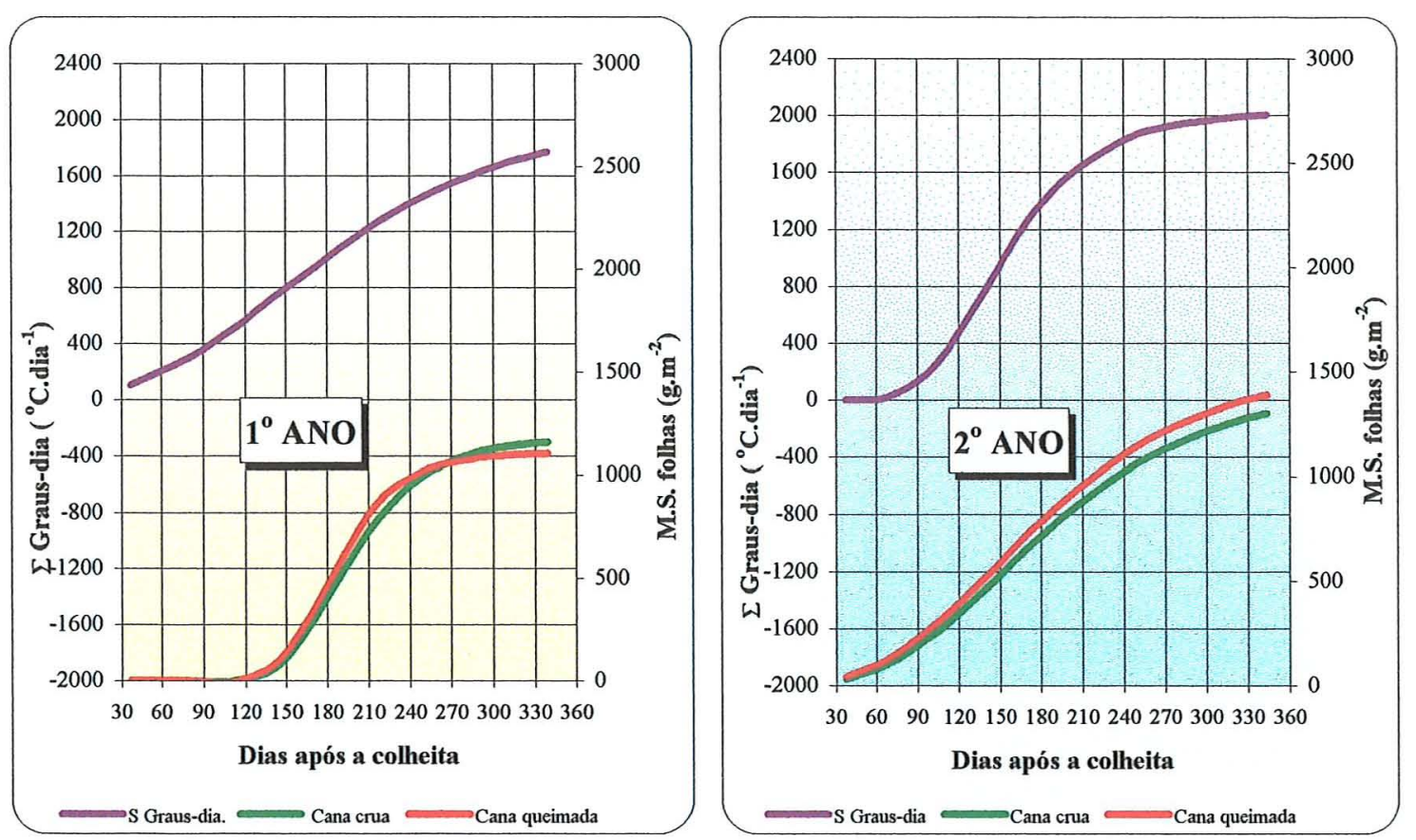

Figura 21 - Acúmulo de graus dia $\left({ }^{\circ} \mathrm{C} \cdot \mathrm{dia}^{-1}\right)$ frente à matéria seca de folhas, no $1^{\underline{0}}$ e $2^{\underline{o}}$ ano de amostragem.
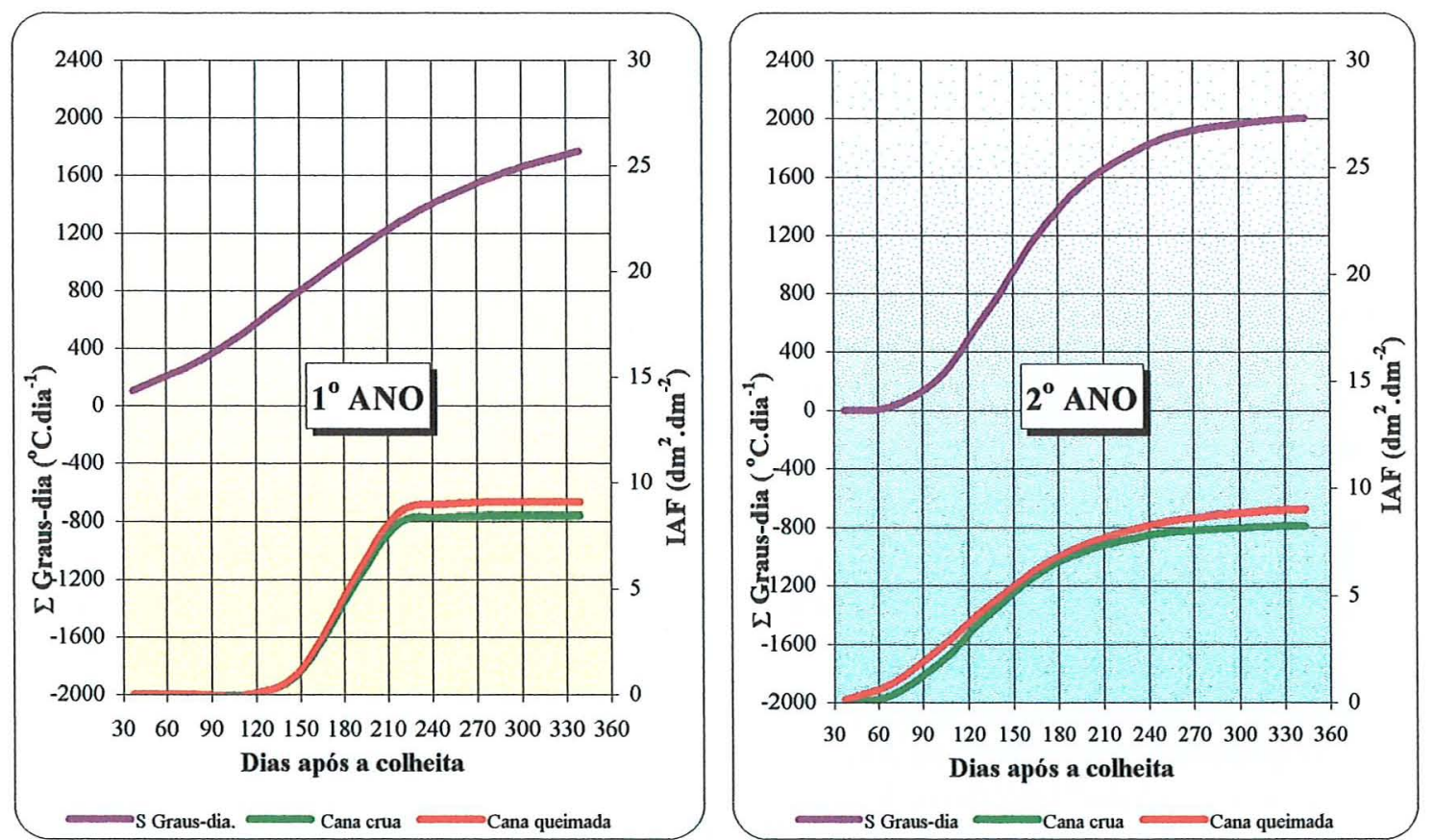

Figura 22 - Acúmulo de graus dia $\left({ }^{\circ} \mathrm{C} \cdot \operatorname{dia}^{-1}\right)$ frente ao IAF, no $1^{\circ}$ e $2^{\underline{o}}$ ano de amostragem. 

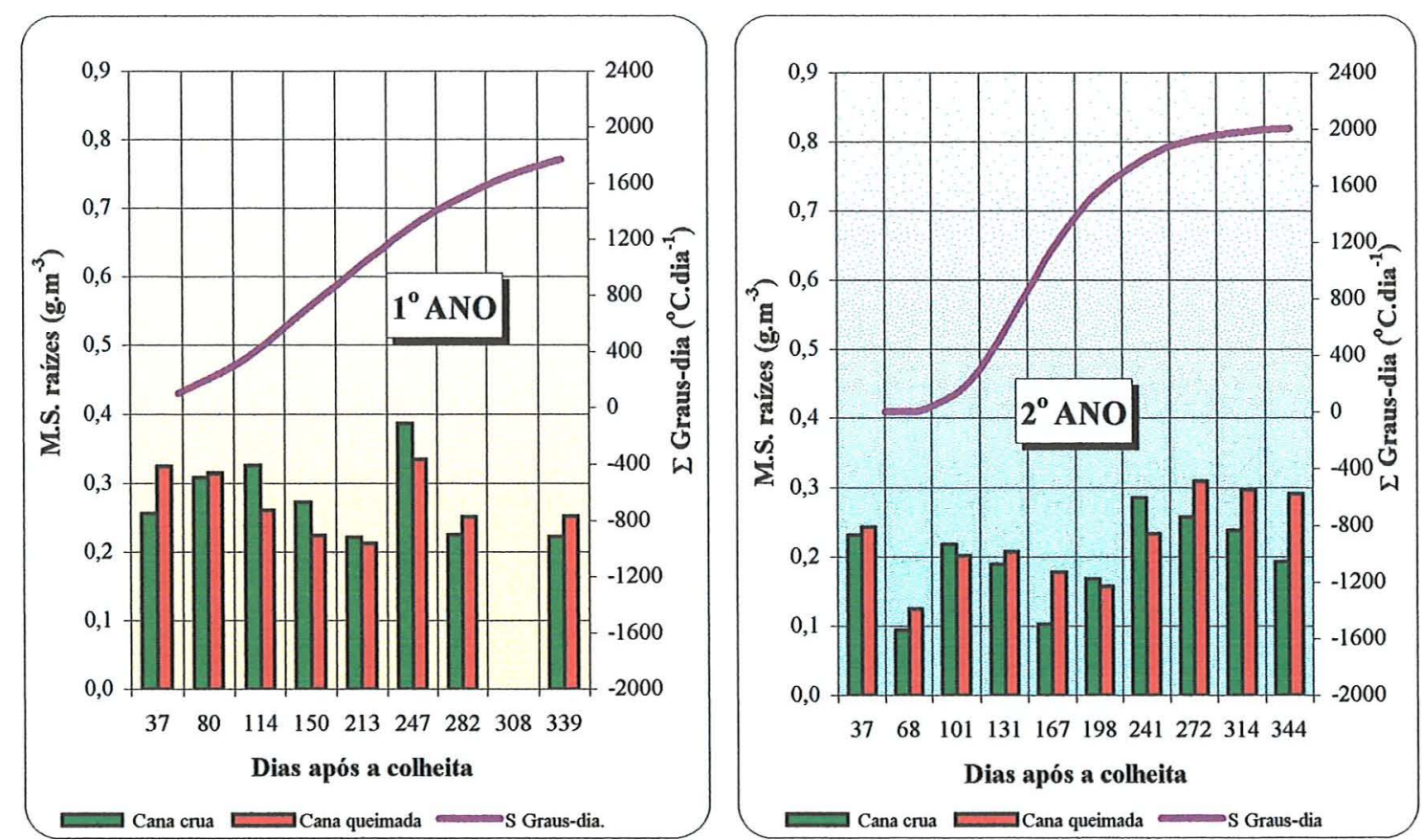

Figura 23 - Acúmulo de graus dia $\left({ }^{\circ} \mathrm{C} \cdot \operatorname{dia}^{-1}\right)$ frente à matéria seca de raízes, no $1^{\underline{0}}$ e $2^{\underline{0}}$ ano de amostragem. 


\subsubsection{Temperatura de folhas}

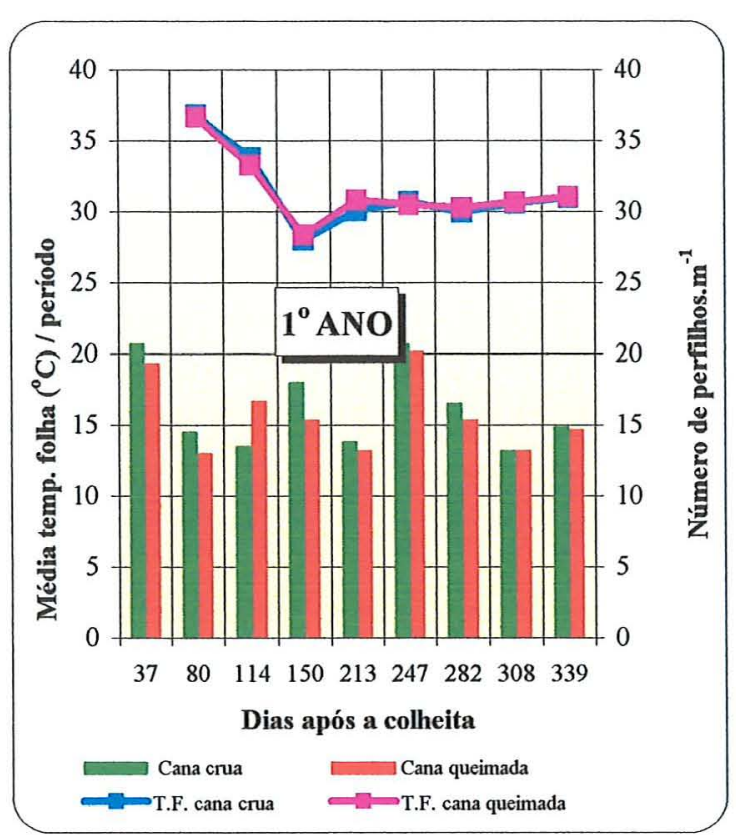

Figura 24 - Temperatura de folhas $\left({ }^{\circ} \mathrm{C}\right)$ frente ao número de perfilhos $/ \mathrm{m}$, no $1^{\circ}$ e $2^{\circ}$ ano de amostragem.

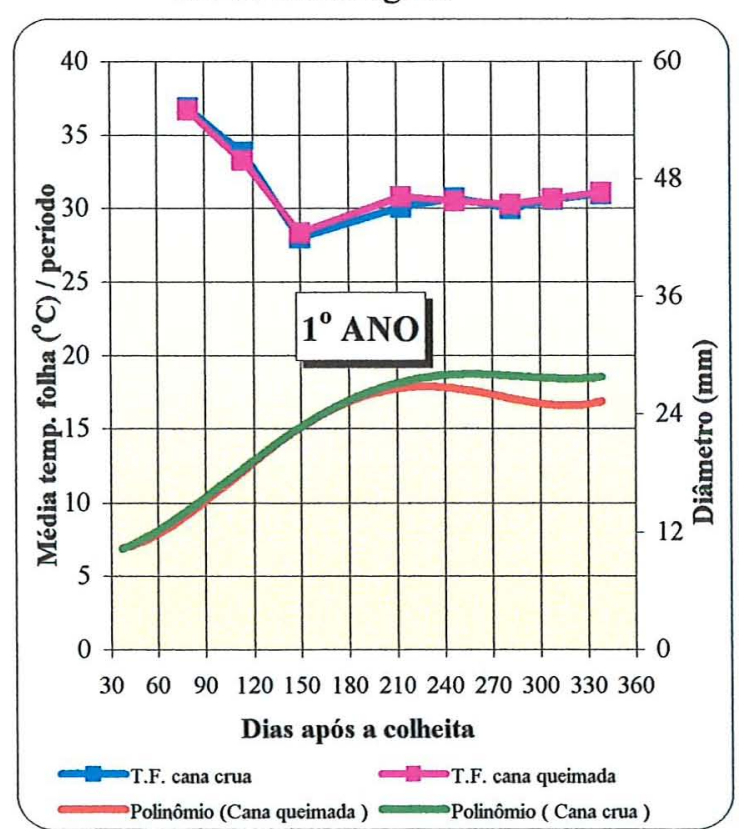

Figura 26 - Temperatura de folhas $\left({ }^{\circ} \mathrm{C}\right)$ frente ao diâmetro de colmos, no $1^{\circ}$ e $2^{\circ}$ ano de amostragem.

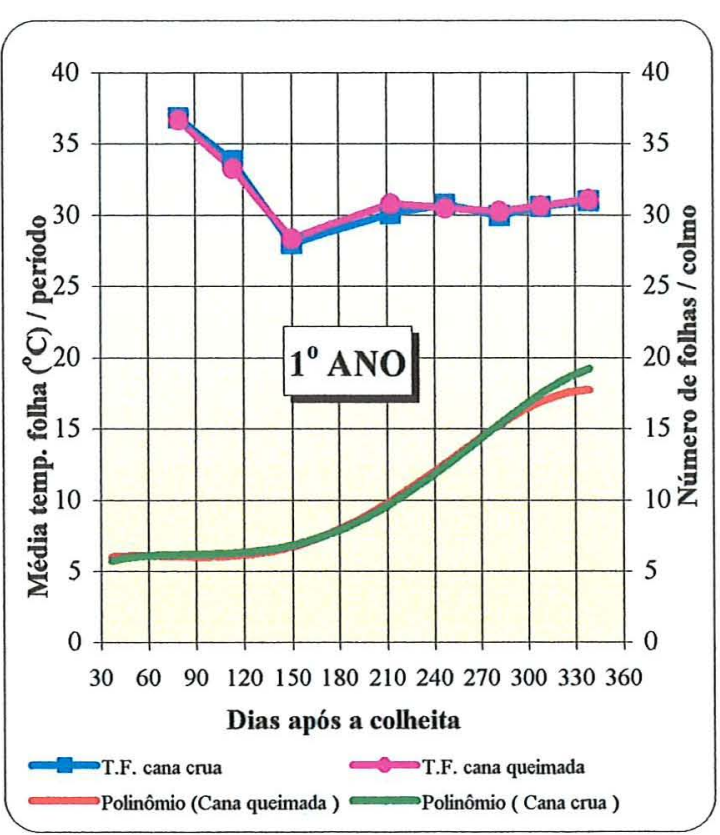

Figura 25 - Temperatura de folhas $\left({ }^{\circ} \mathrm{C}\right)$ frente ao número de folhas / colmo, no $1^{\circ}$ e $2^{\underline{0}}$ ano de amostragem.

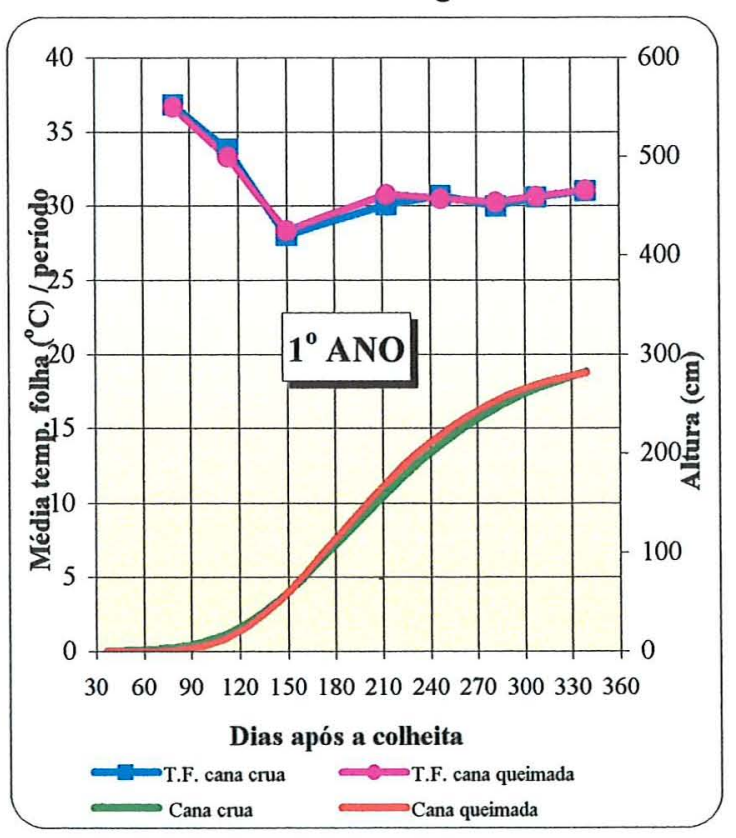

Figura 27 - Temperatura de folhas $\left({ }^{\circ} \mathrm{C}\right)$ frente à altura de plantas, no $1^{\circ}$ e $2^{\circ}$ ano de amostragem. 


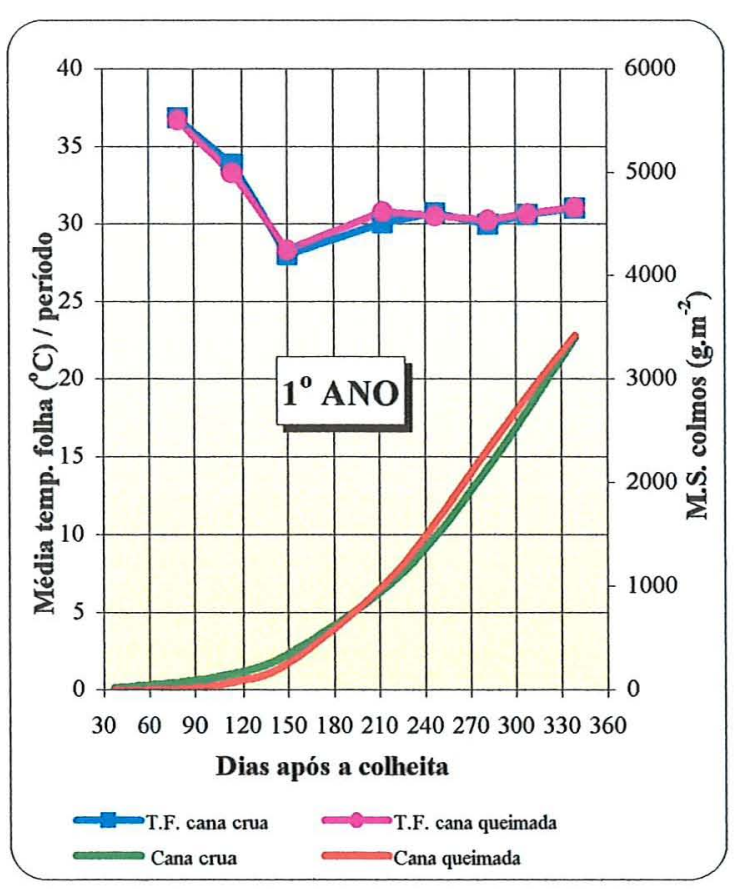

Figura 28 - Temperatura de folhas $\left({ }^{\circ} \mathrm{C}\right)$ frente à matéria seca de colmos, no $1^{\circ}$ e $2^{\underline{o}}$ ano de amostragem.

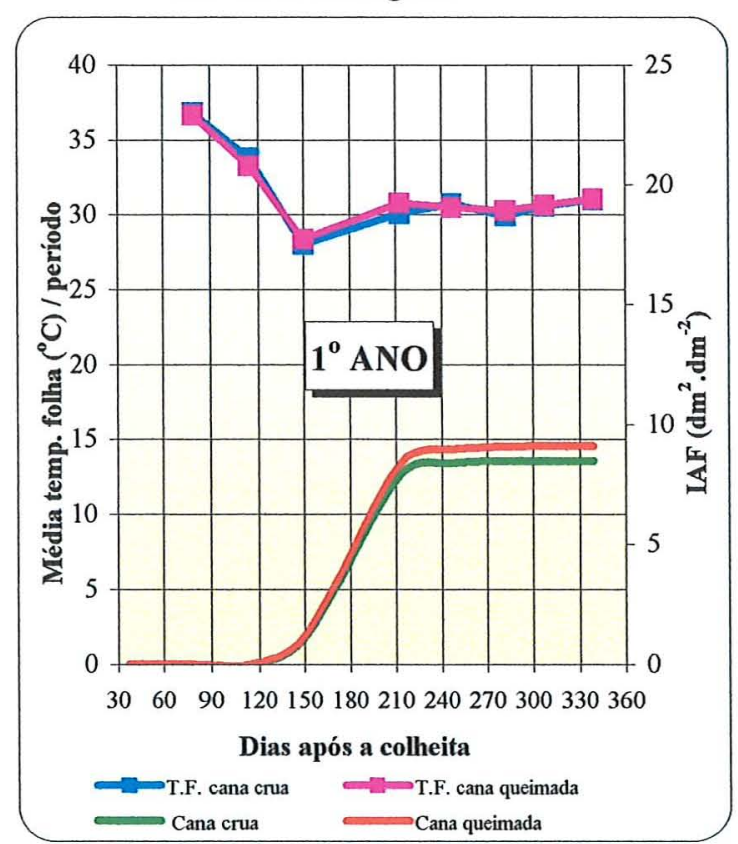

Figura 30 - Temperatura de folhas $\left({ }^{\circ} \mathrm{C}\right)$ frente ao IAF, no $1^{\circ}$ e $2^{\circ}$ ano de amostragem.

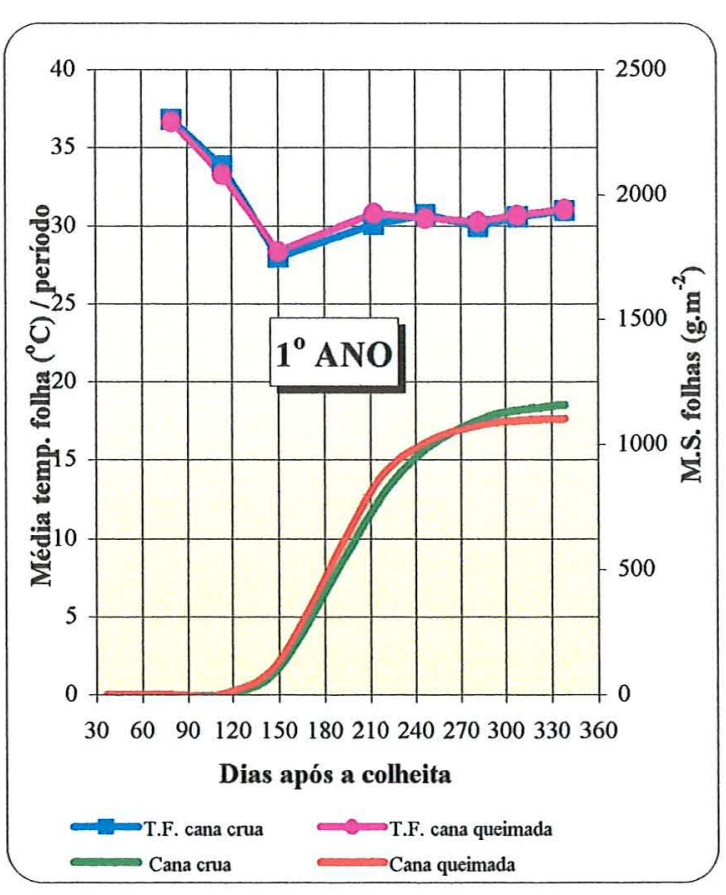

Figura 29 - Temperatura de folhas $\left({ }^{\circ} \mathrm{C}\right)$ frente à matéria seca de folhas, no $1^{\underline{0}}$ e $2^{\underline{o}}$ ano de amostragem.

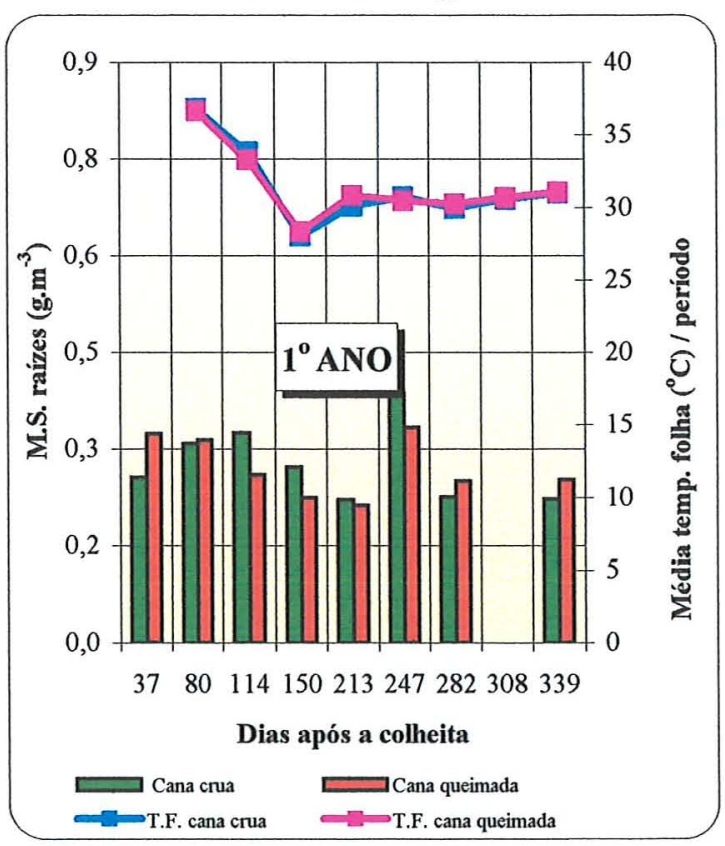

Figura 31 - Temperatura de folhas $\left({ }^{\circ} \mathrm{C}\right)$ frente à matéria seca de raízes, no $1^{\circ}$ e $2^{\circ}$ ano de amostragem. 


\subsubsection{Temperatura do solo}
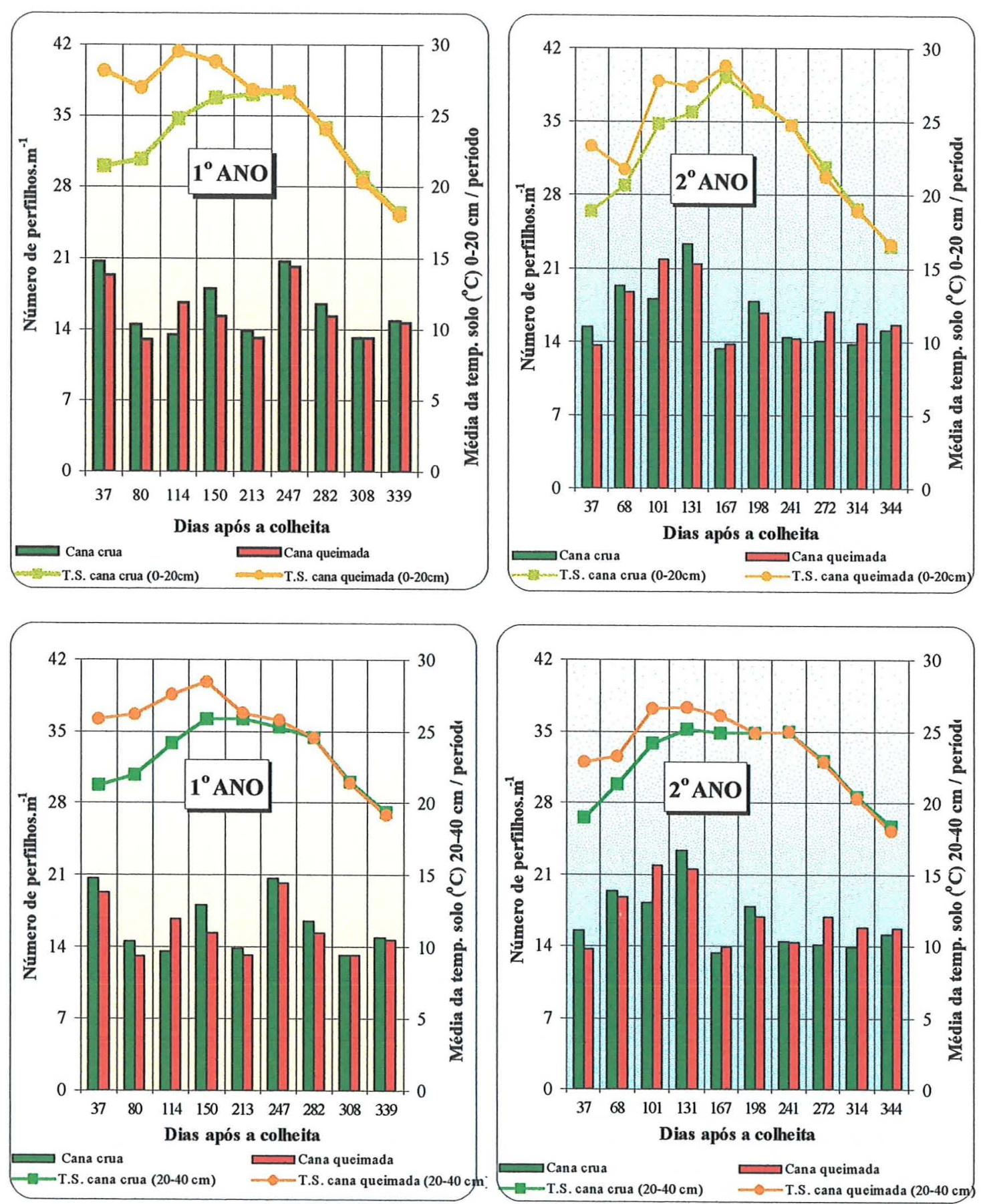

Figura 32 - Temperatura do solo $\left({ }^{\circ} \mathrm{C}\right)$, em duas profundidades, frente ao número de perfilhos / $\mathrm{m}$, no $1^{\underline{0}}$ e $2^{\underline{0}}$ ano de amostragem. 

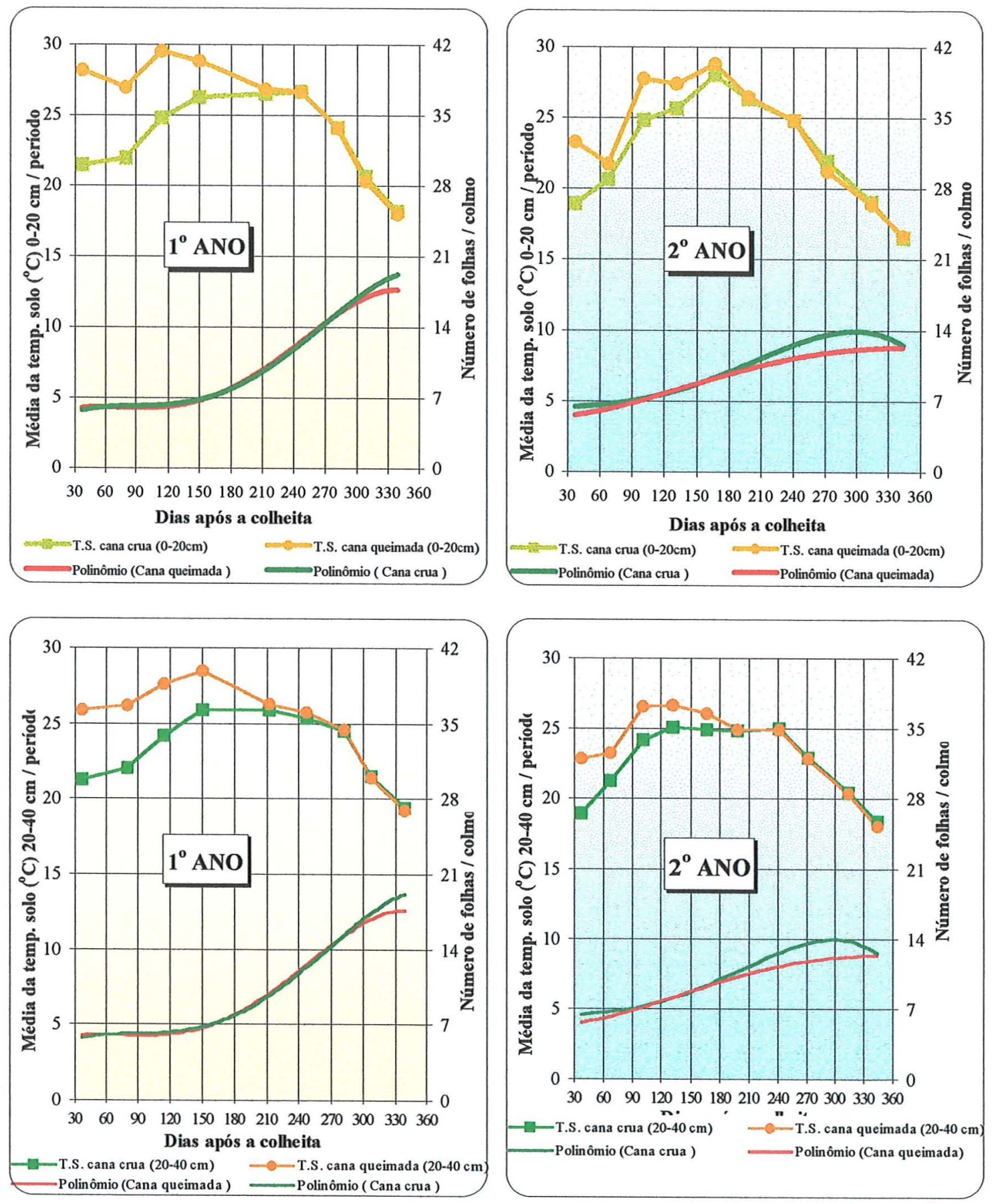

Figura 33 - Temperatura do solo $\left({ }^{\circ} \mathrm{C}\right)$, em duas profundidades, frente ao número de folhas / colmo, no $1^{\circ}$ e $2^{\circ}$ ano de amostragem. 

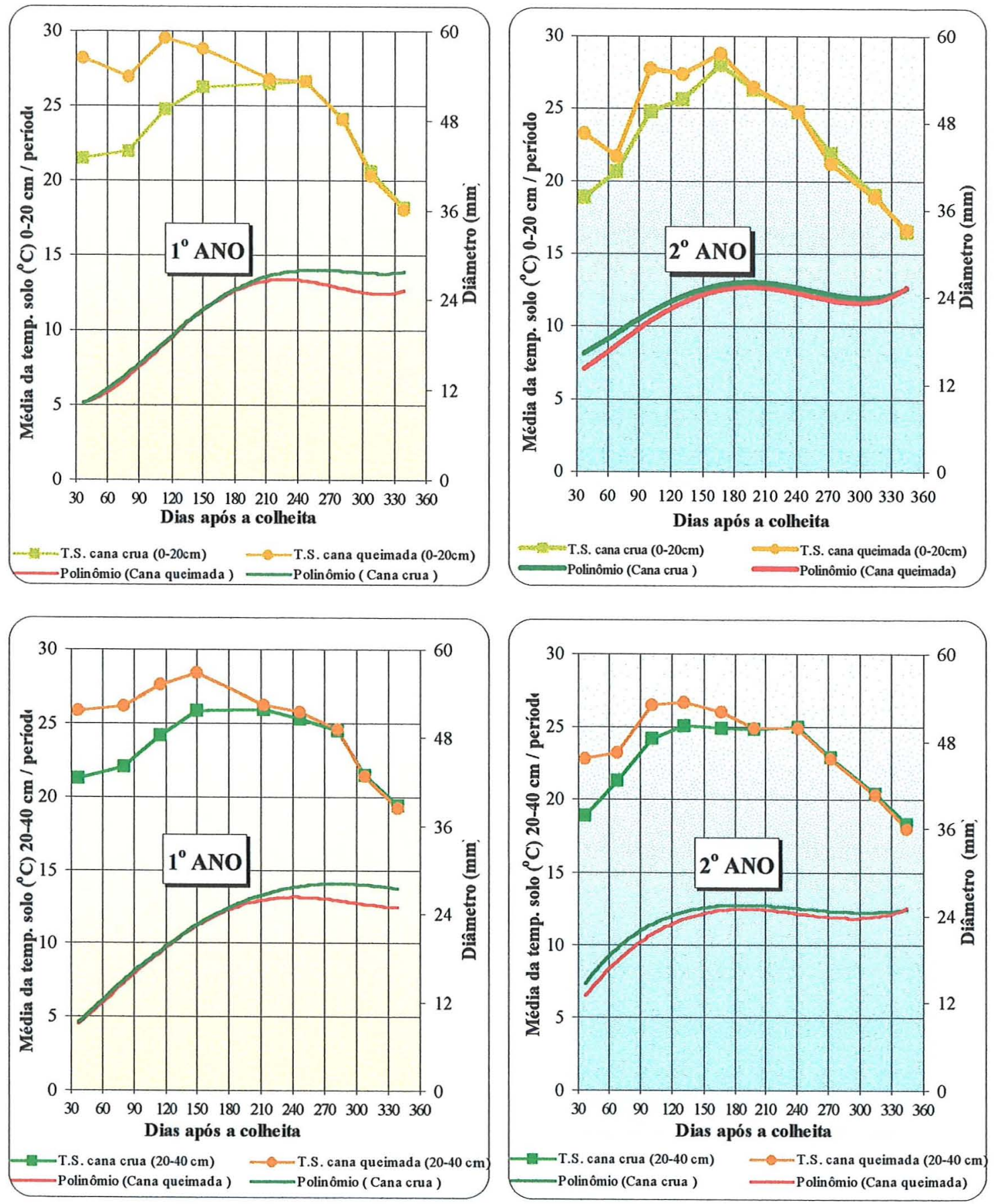

Figura 34 - Temperatura do solo $\left({ }^{\circ} \mathrm{C}\right)$, em duas profundidades, frente ao diâmetro de colmos, no $1^{\underline{o}}$ e $2^{\circ}$ ano de amostragem. 

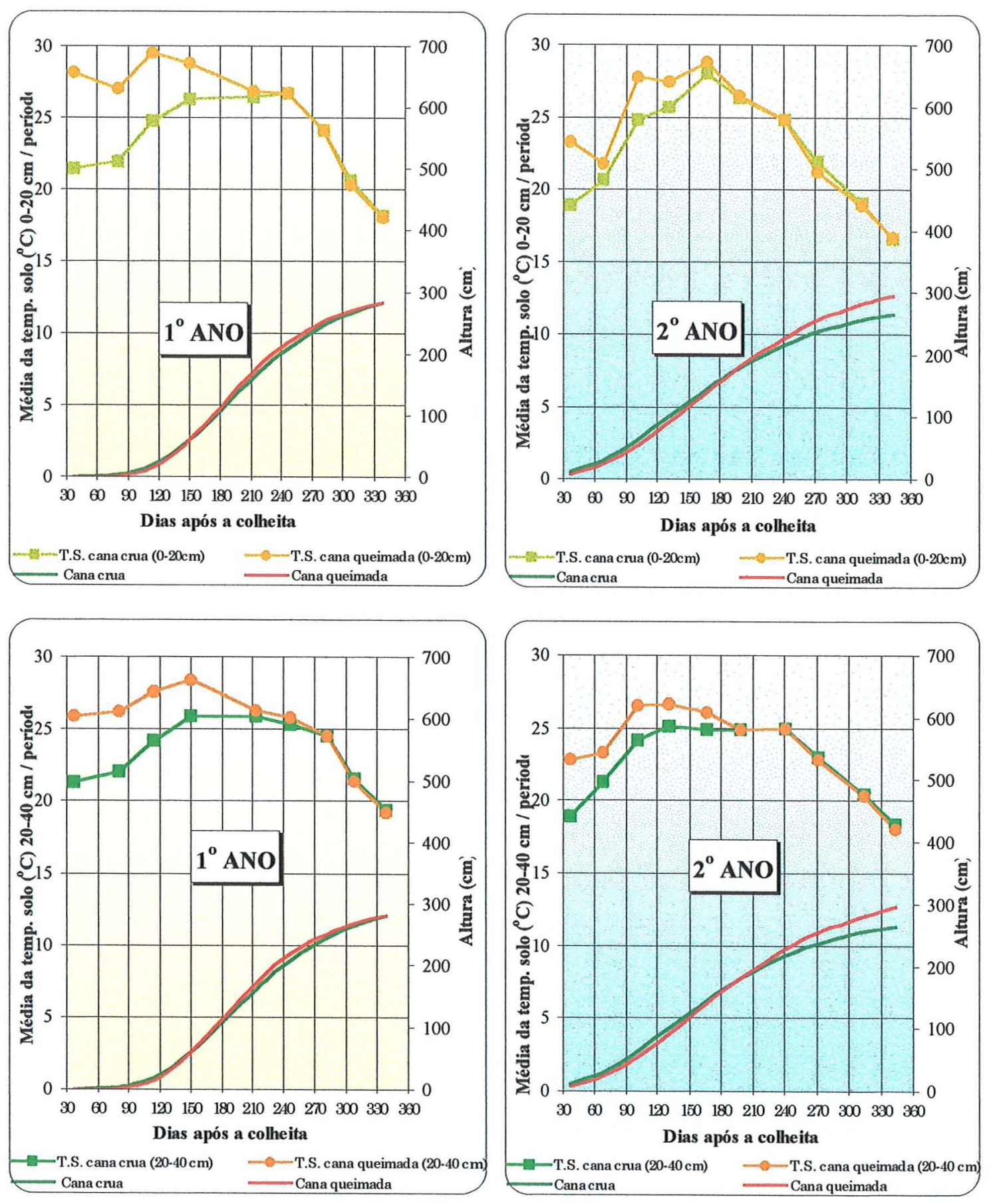

Figura 35 - Temperatura do solo $\left({ }^{\circ} \mathrm{C}\right)$, em duas profundidades, frente à altura de plantas, no $1^{\circ} \underline{e} 2^{\underline{o}}$ ano de amostragem. 

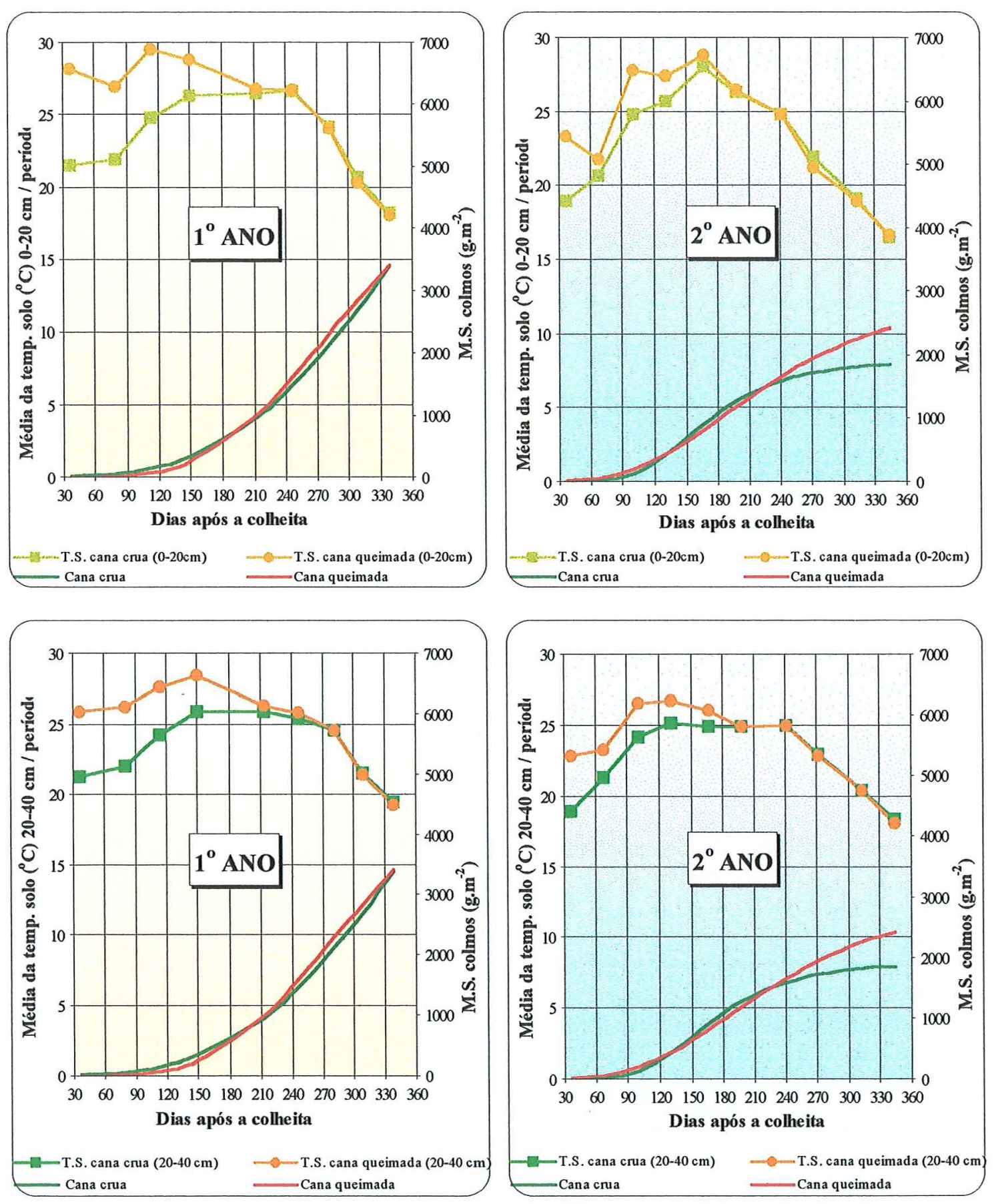

Figura 36 - Temperatura do solo $\left({ }^{\circ} \mathrm{C}\right)$, em duas profundidades, frente à matéria seca de colmos, no $1^{\underline{0}}$ e $2^{\underline{0}}$ ano de amostragem. 

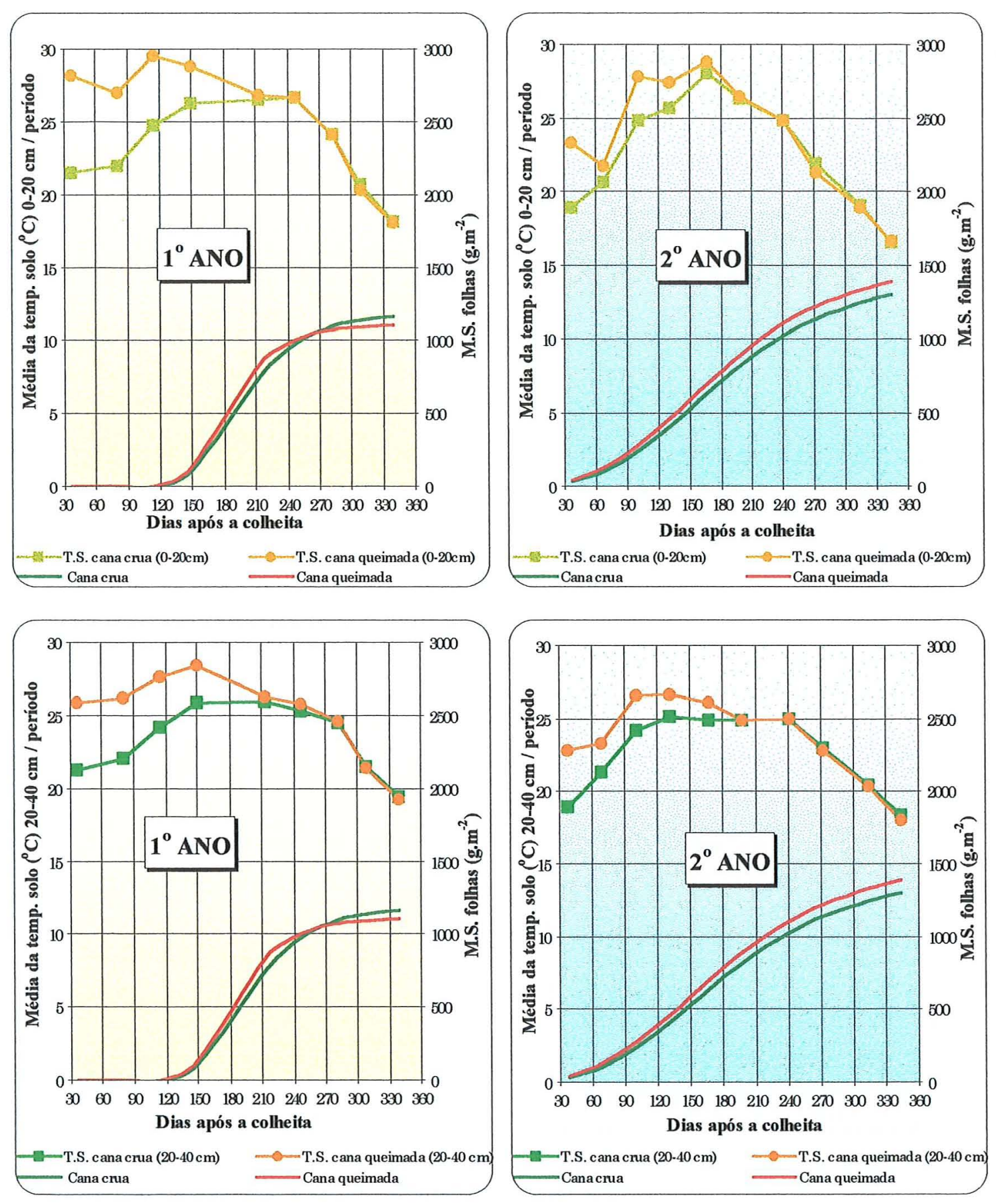

Figura 37 - Temperatura do solo $\left({ }^{\circ} \mathrm{C}\right)$, em duas profundidades, frente à matéria seca de folhas, no $1^{\circ}$ e $2^{\circ}$ ano de amostragem. 

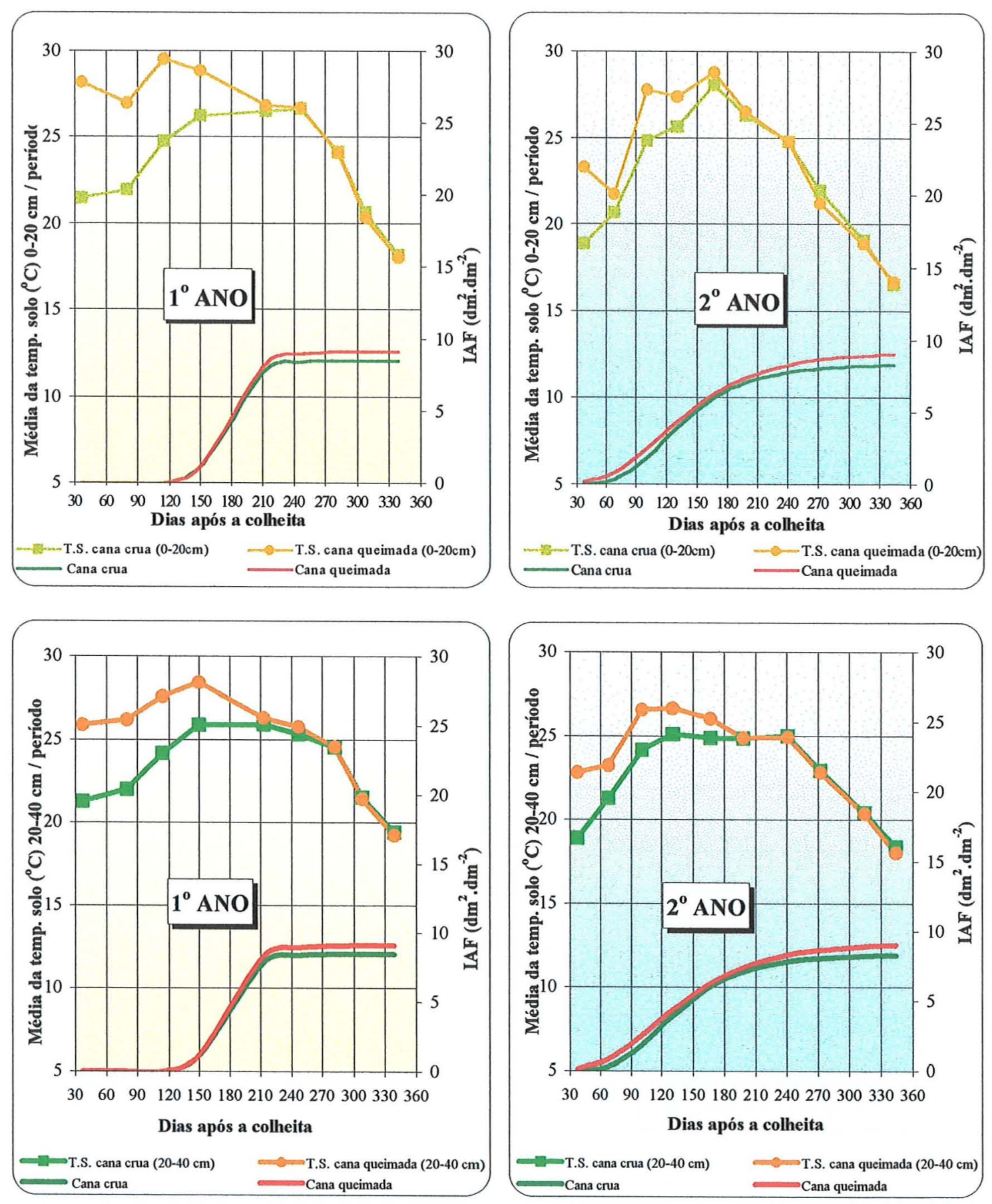

Figura 38 - Temperatura do solo $\left({ }^{\circ} \mathrm{C}\right)$, em duas profundidades, frente ao IAF, no $1^{\circ}$ e $2^{\circ}$ ano de amostragem. 

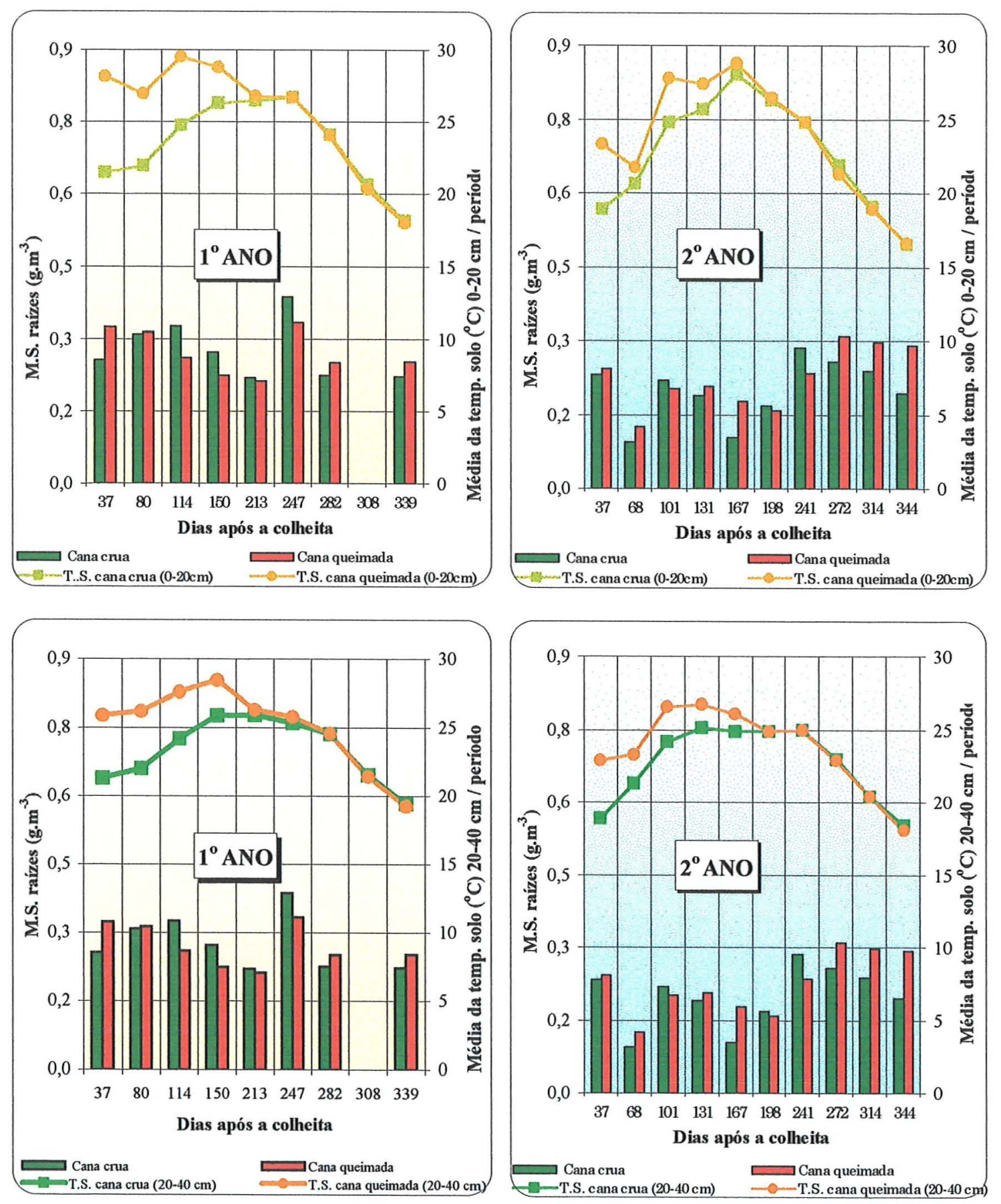

Figura 39 - Temperatura do solo $\left({ }^{\circ} \mathrm{C}\right)$, em duas profundidades, frente à matéria seca de raízes, no $1^{\circ}$ e $2^{\circ}$ ano de amostragem. 


\subsubsection{Umidade relativa do ar}
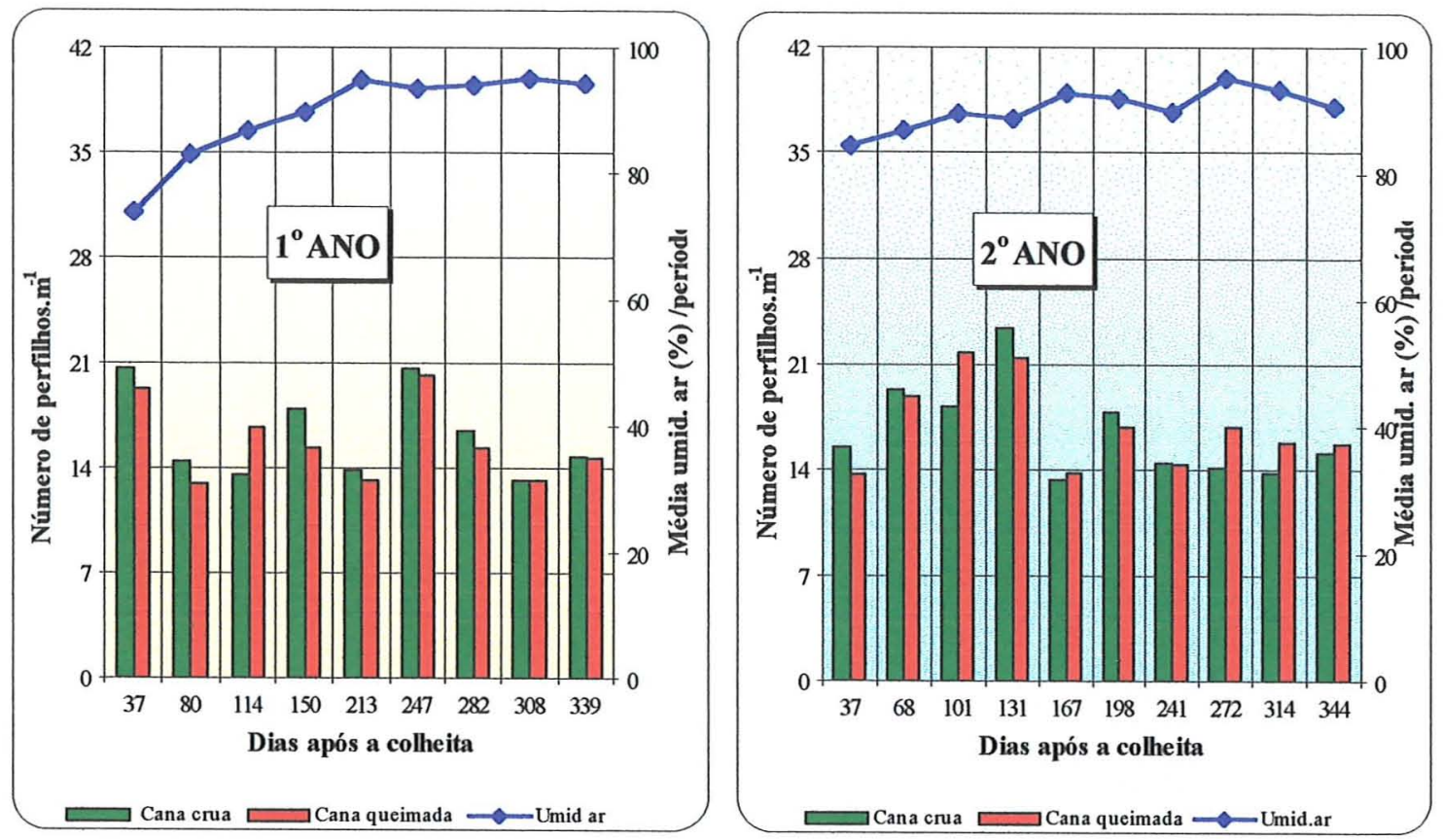

Figura 40 - Umidade relativa do ar (\%) frente ao número de perfilhos / $\mathrm{m}$ linear, no $1^{\circ}$ e $2^{\underline{o}}$ ano de amostragem.
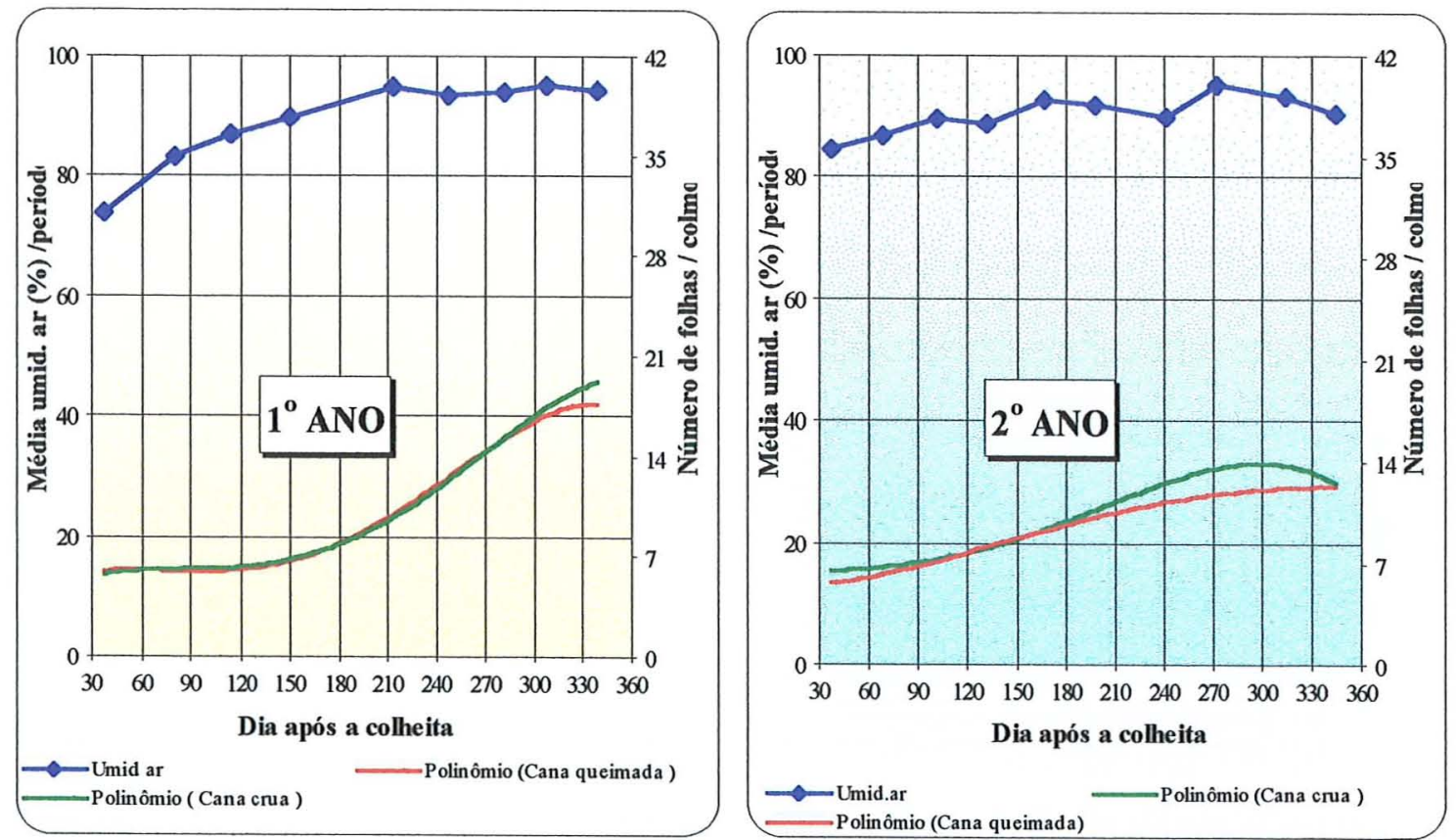

Figura 41 - Umidade relativa do ar (\%) frente ao número de folhas / colmo, no $1^{\underline{0}}$ e $2^{\underline{0}}$ ano de amostragem. 

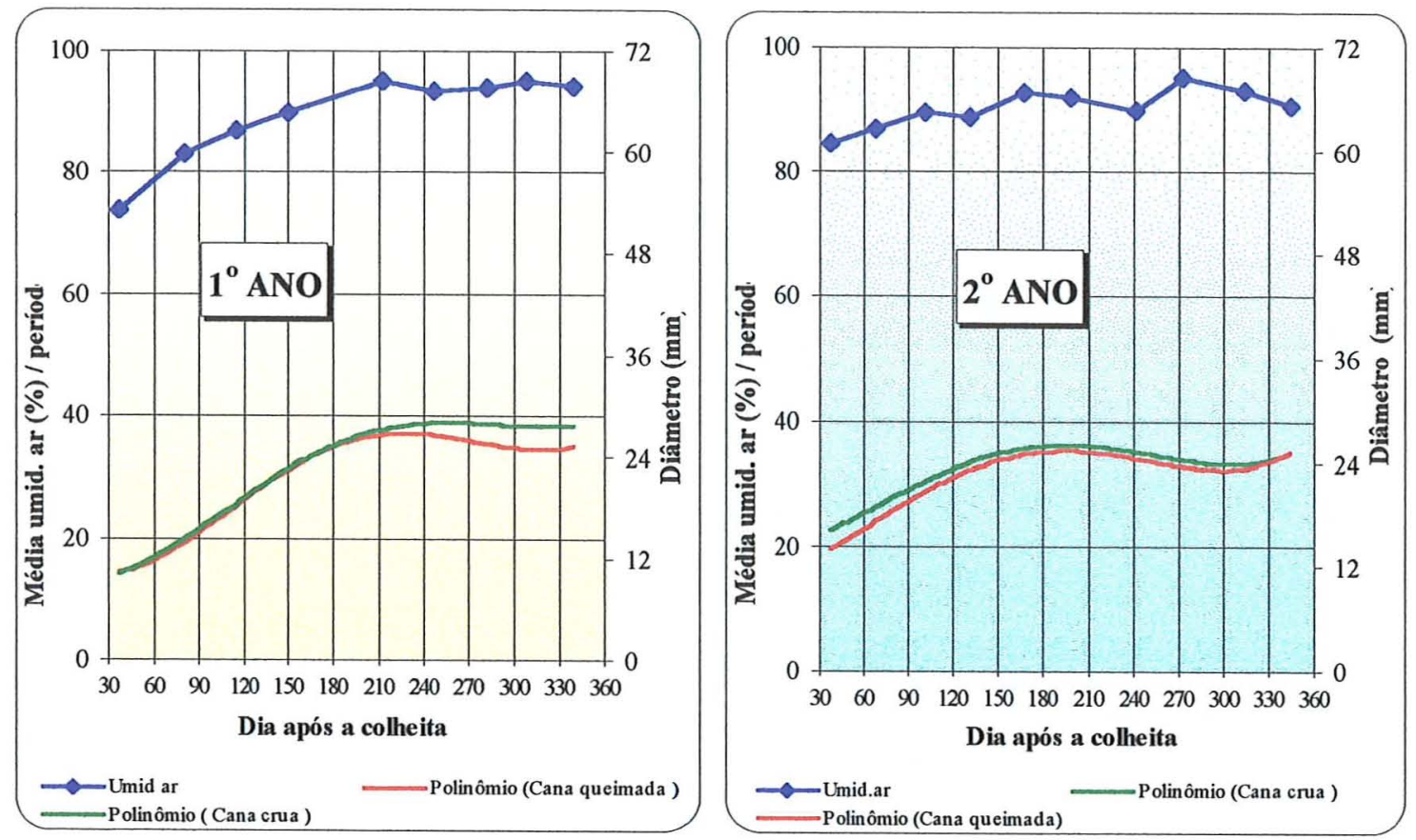

Figura 42 - Umidade relativa do ar (\%) frente ao diâmetro de colmos, no $1^{\circ}$ e $2^{2}$ ano de amostragem.
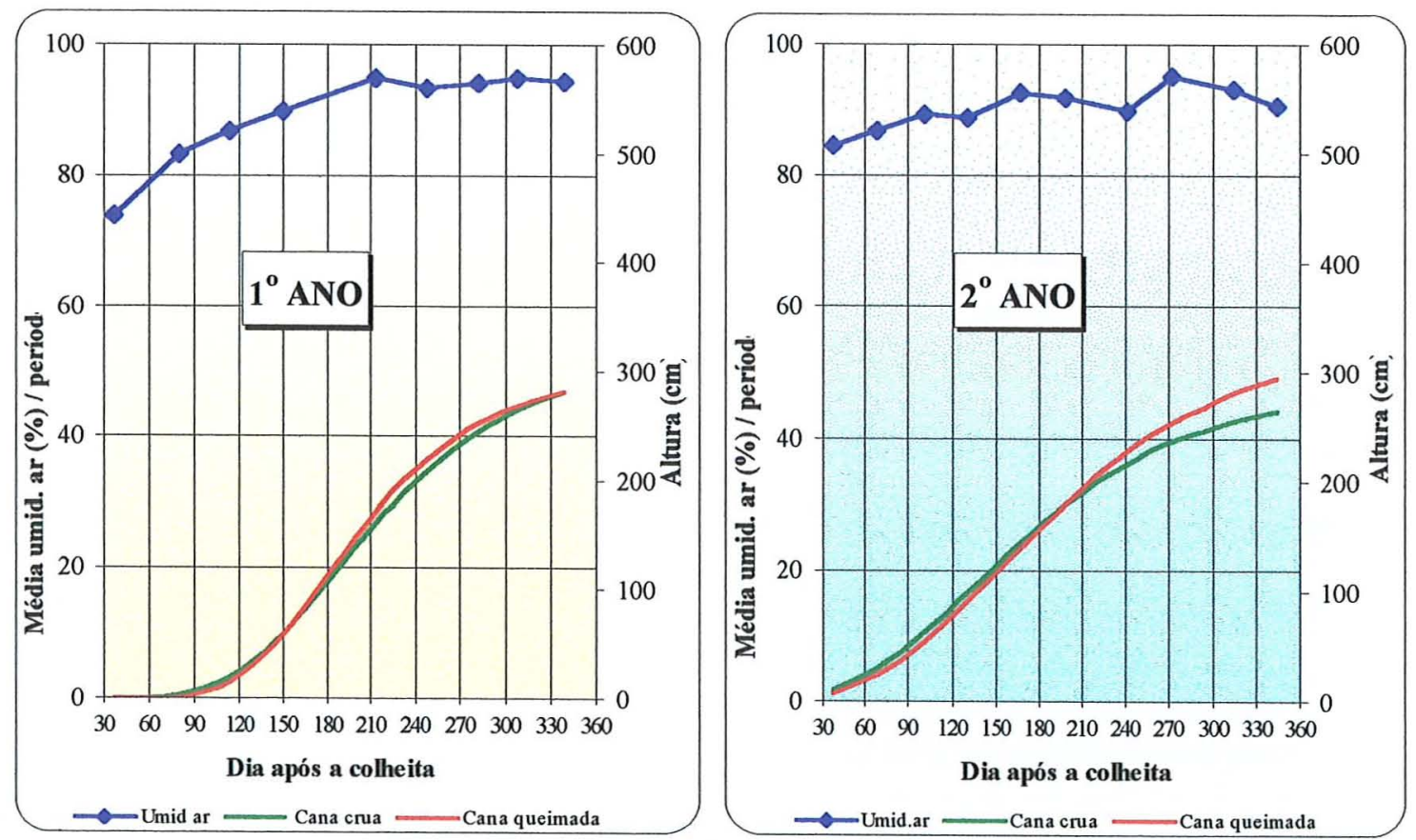

Figura 43 - Umidade relativa do ar (\%) frente à altura de plantas, no $1^{\circ}$ e $2^{\circ}$ ano de amostragem. 

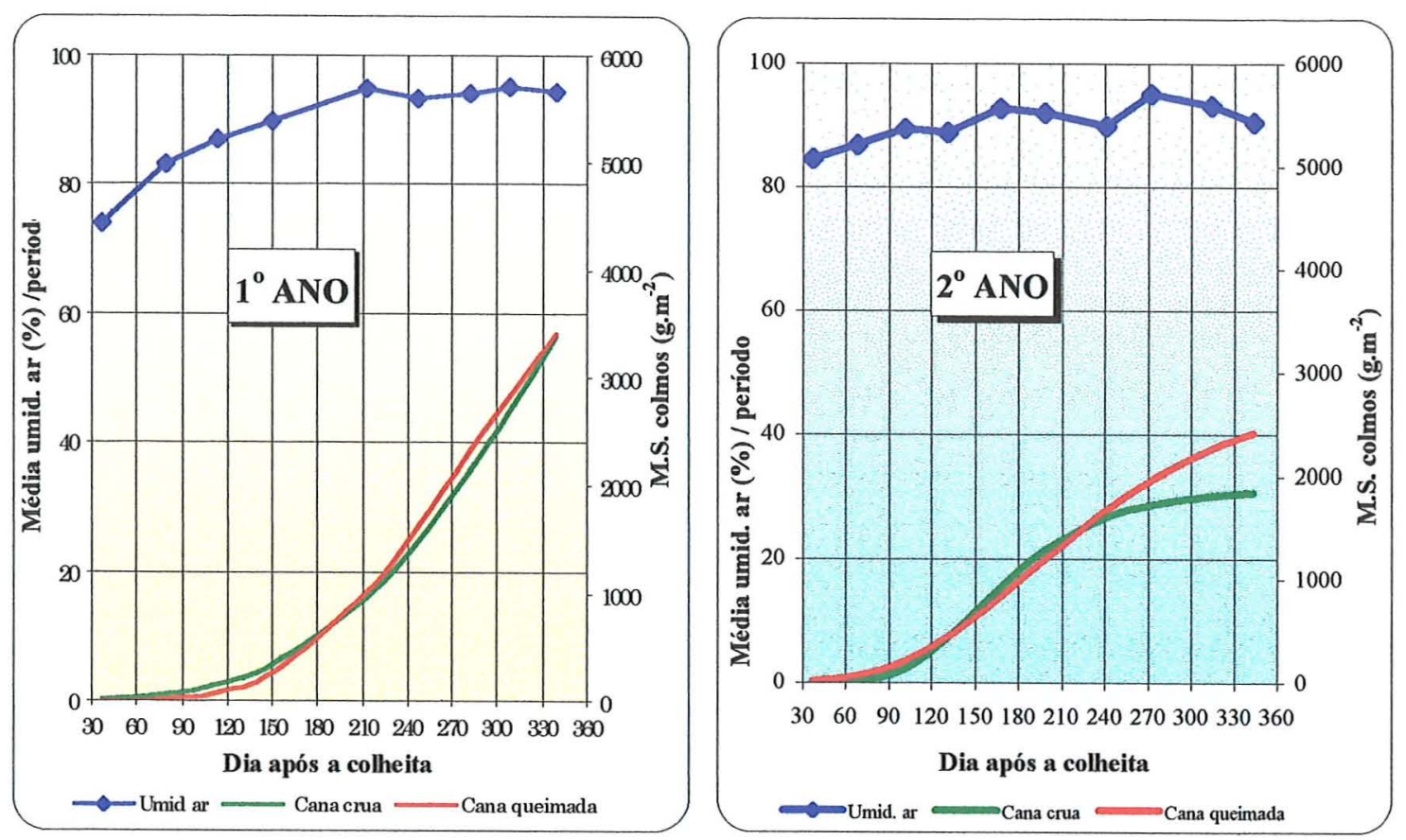

Figura 44 - Umidade relativa do ar (\%) frente à matéria seca de colmos, no $1^{\circ}$ e $2^{\circ}$ ano de amostragem.
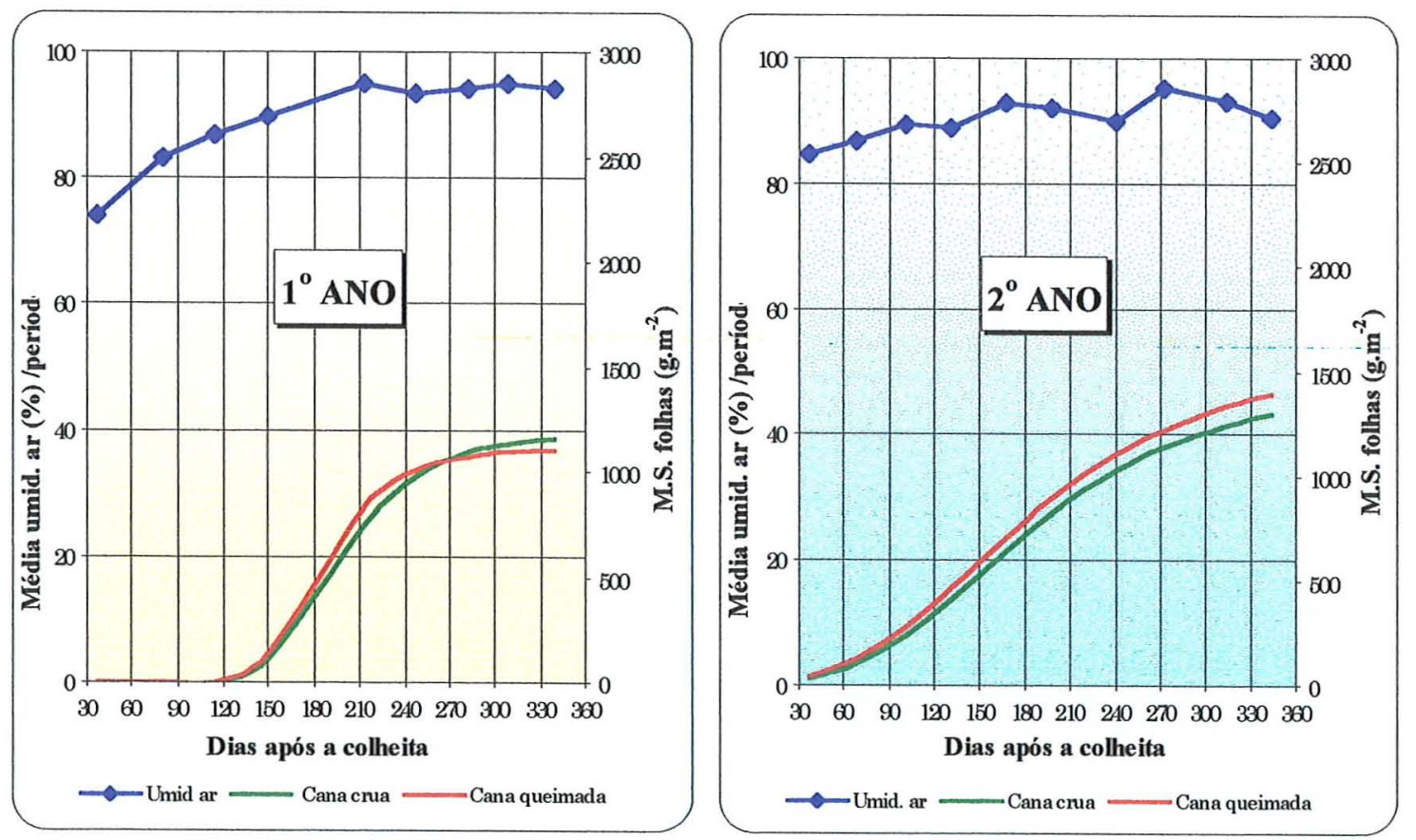

Figura 45 - Umidade relativa do ar (\%) frente à matéria seca de folhas, no $1^{\circ}$ e $2^{\circ}$ ano de amostragem. 

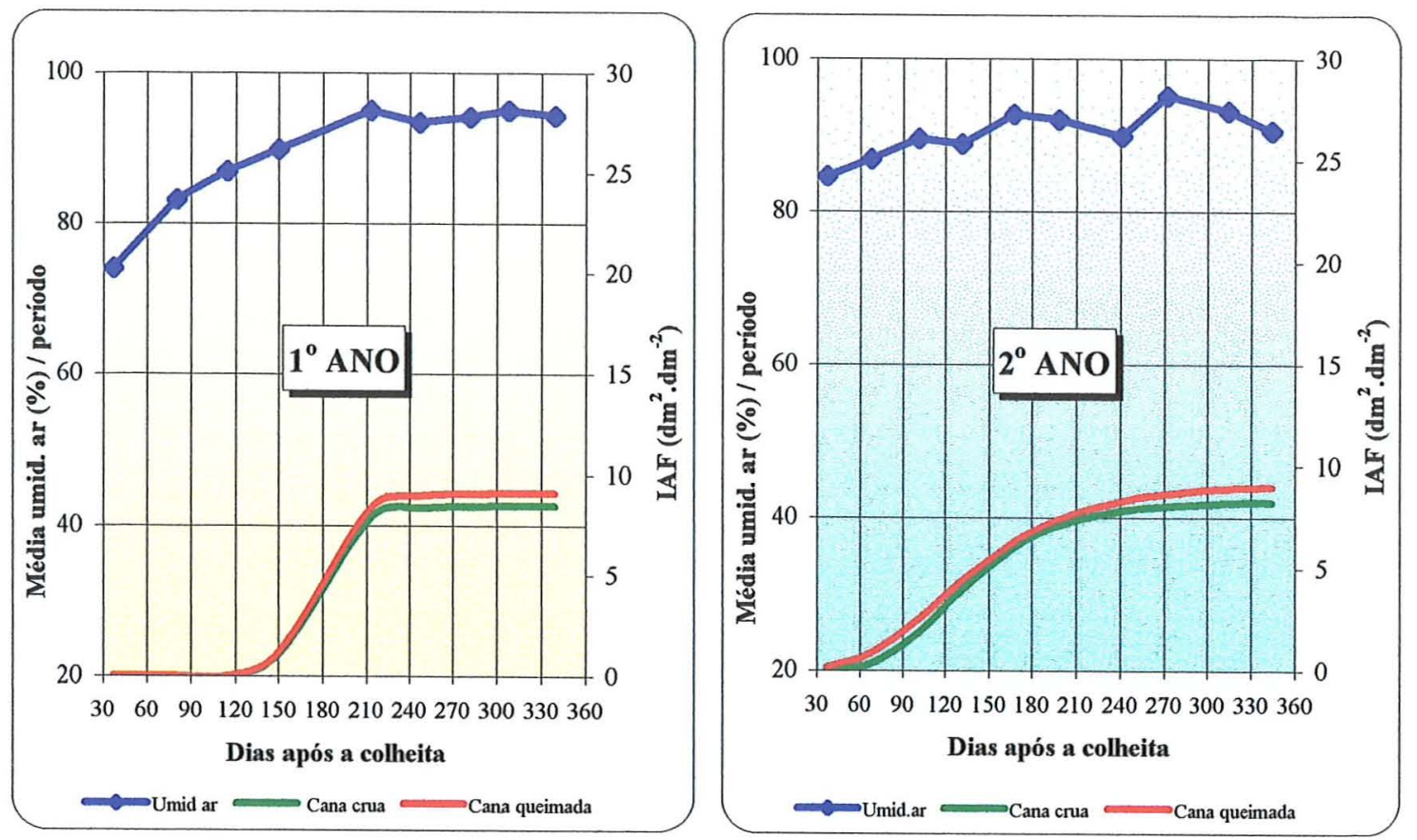

Figura 46 - Umidade relativa do ar (\%) frente ao IAF, no $1^{\circ}$ e $2^{\underline{0}}$ ano de amostragem.
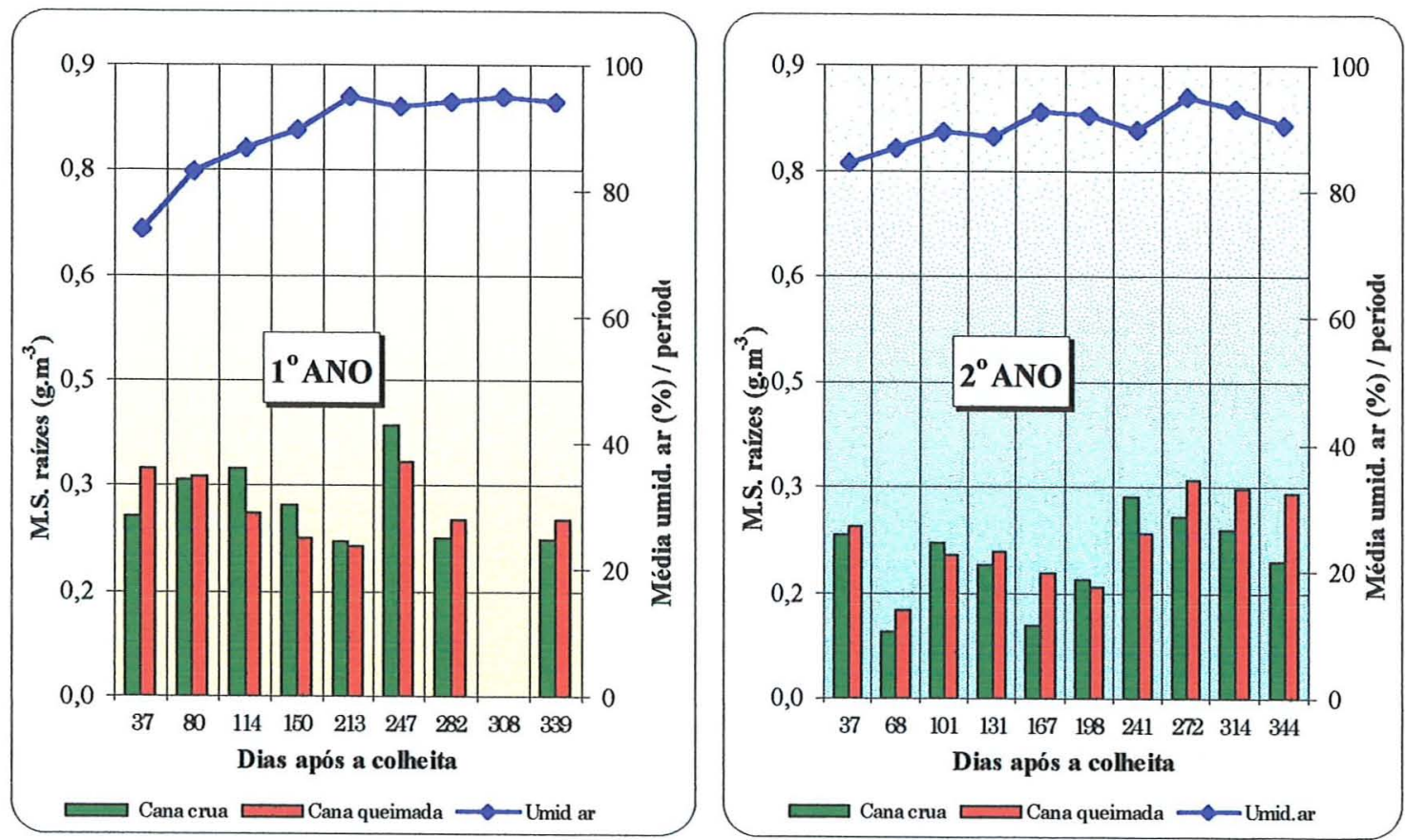

Figura 47 - Umidade relativa do ar (\%) frente à matéria seca de raízes, no $1^{\circ}$ e $2^{\underline{0}}$ ano de amostragem. 


\subsubsection{Umidade relativa de folhas}

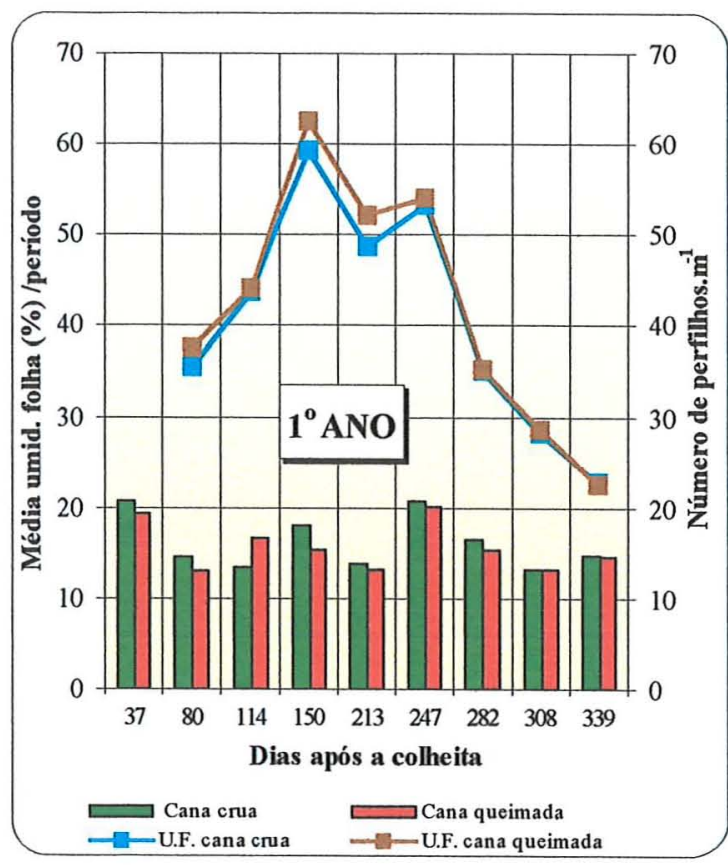

Figura 48 - Umidade de folhas (\%) frente ao número de perfilhos $/ \mathrm{m}$, no $1^{\circ}$ e $2^{\underline{0}}$ ano de amostragem.

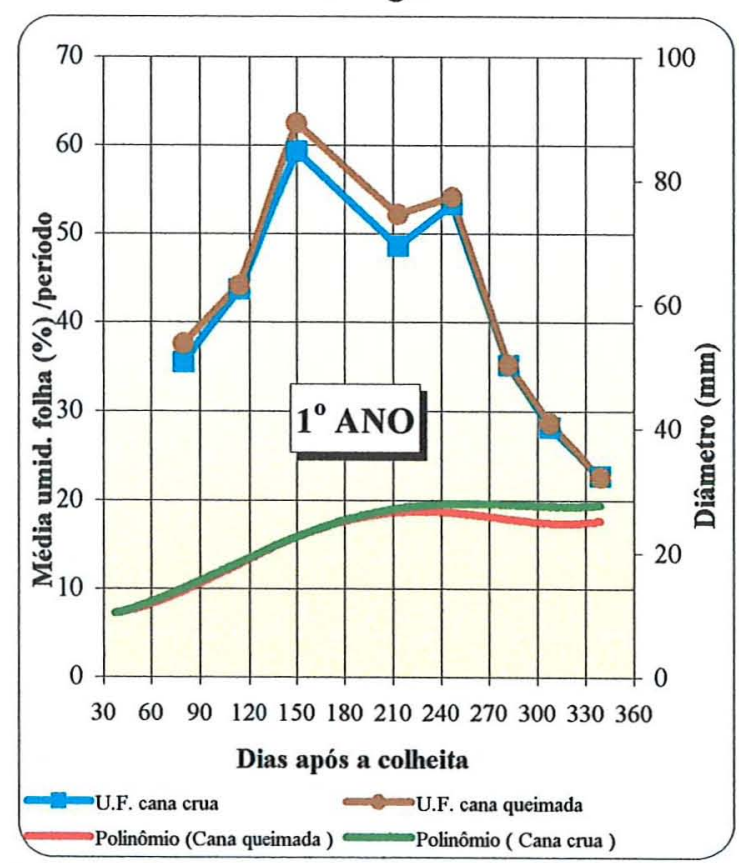

Figura 50 - Umidade de folhas (\%) frente ao diâmetro de colmos, no $1^{\circ}$ e $2^{\underline{0}}$ ano de amostragem.

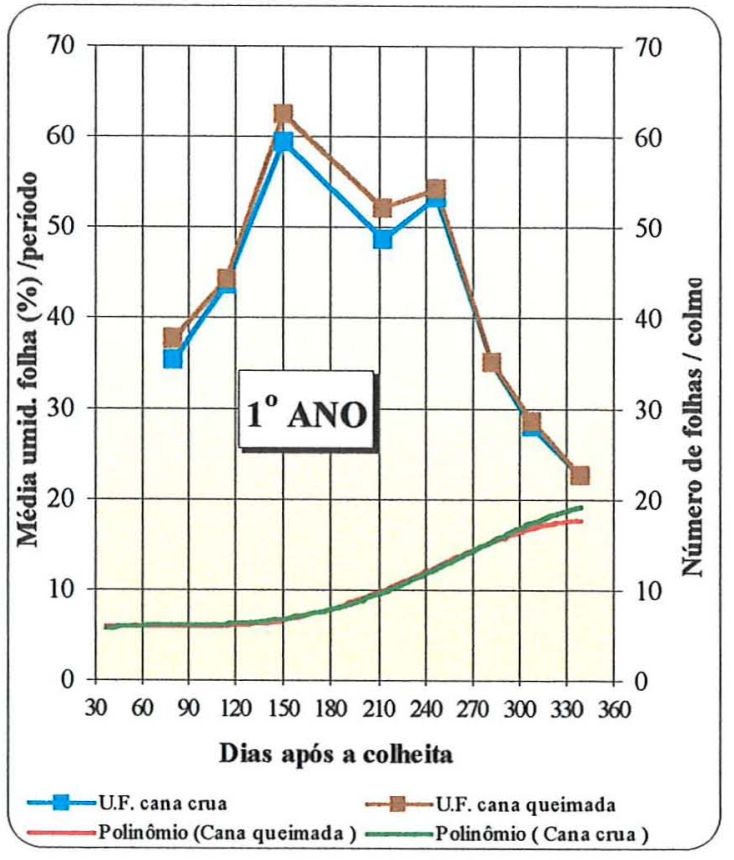

Figura 49 - Umidade de folhas (\%) frente ao número de folhas, no $1^{\circ}$ e $2^{\circ}$ ano de amostragem.

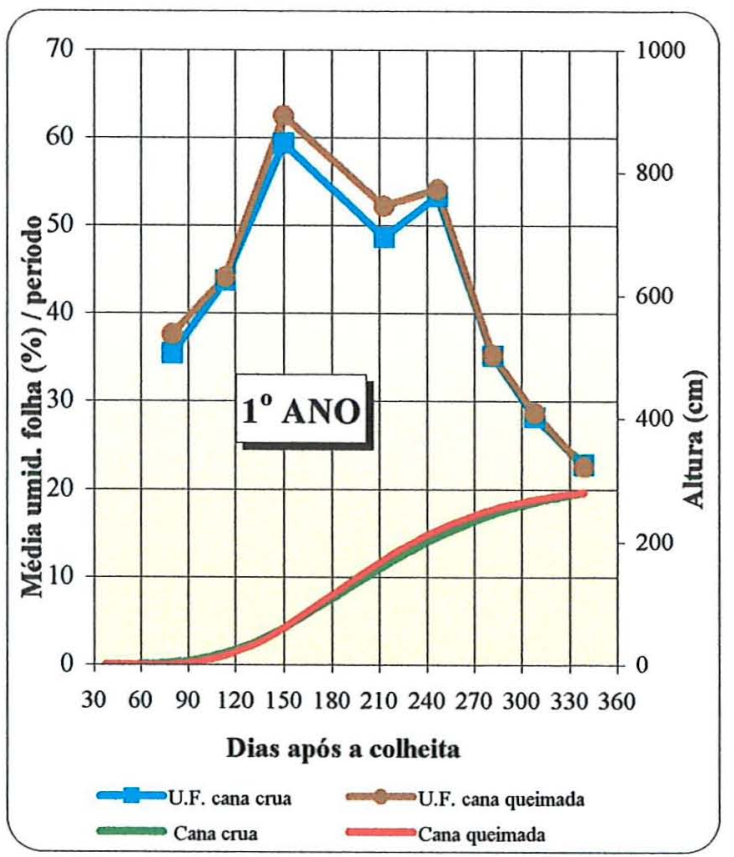

Figura 51 - Umidade de folhas (\%) frente à altura de plantas, no $1^{\underline{0}}$ e $2^{\underline{0}}$ ano de amostragem. 


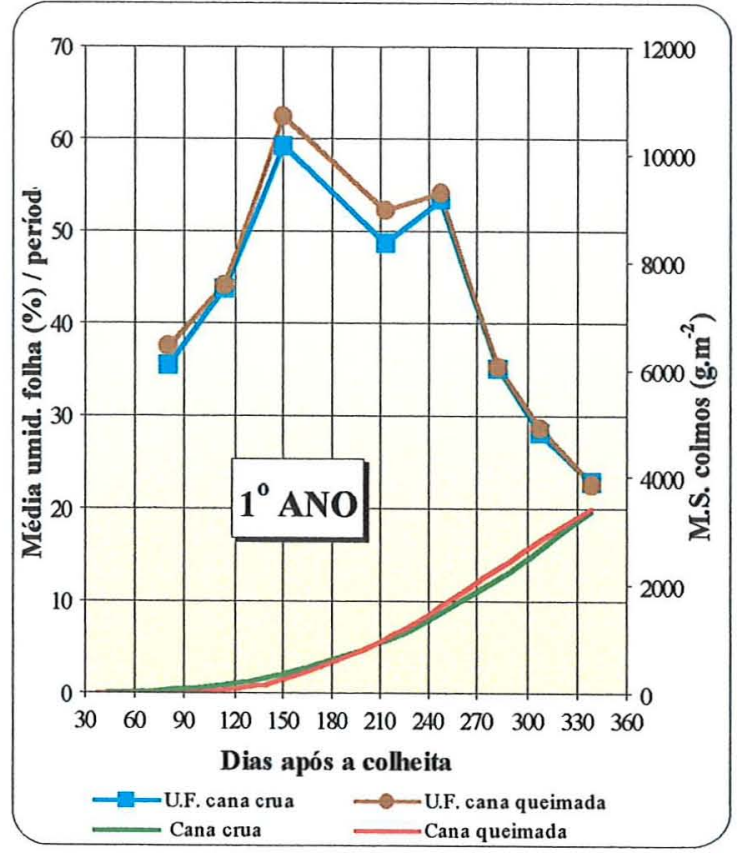

Figura 52 - Umidade de folhas (\%) frente à matéria seca de colmos, no $1^{\underline{0}}$ e $2^{\underline{0}}$ ano de amostragem.

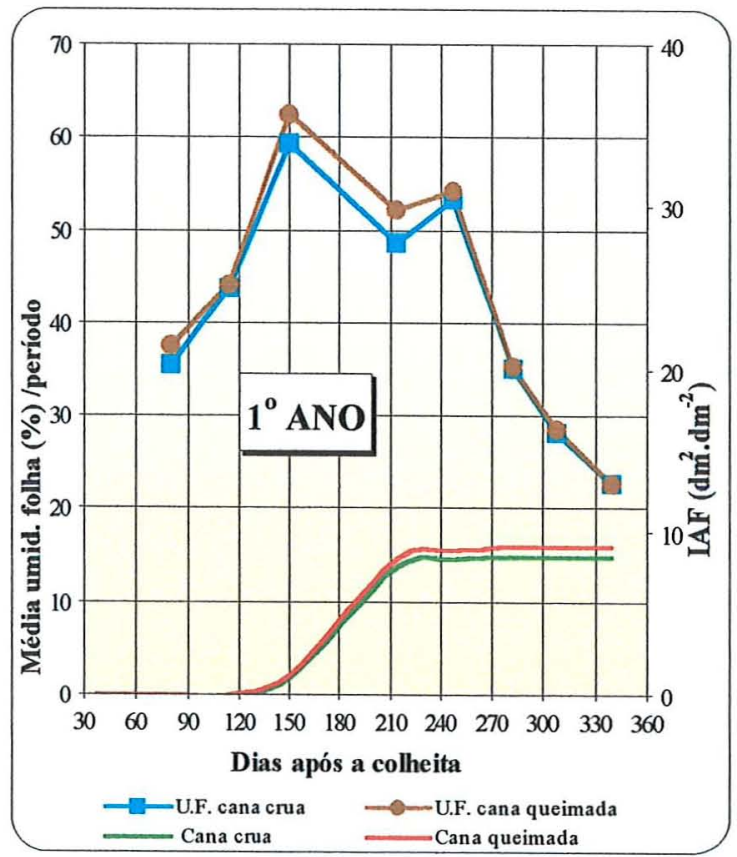

Figura 54 - Umidade de folhas (\%) frente ao IAF, no $1^{0}$ e $2^{\underline{0}}$ ano de amostragem.

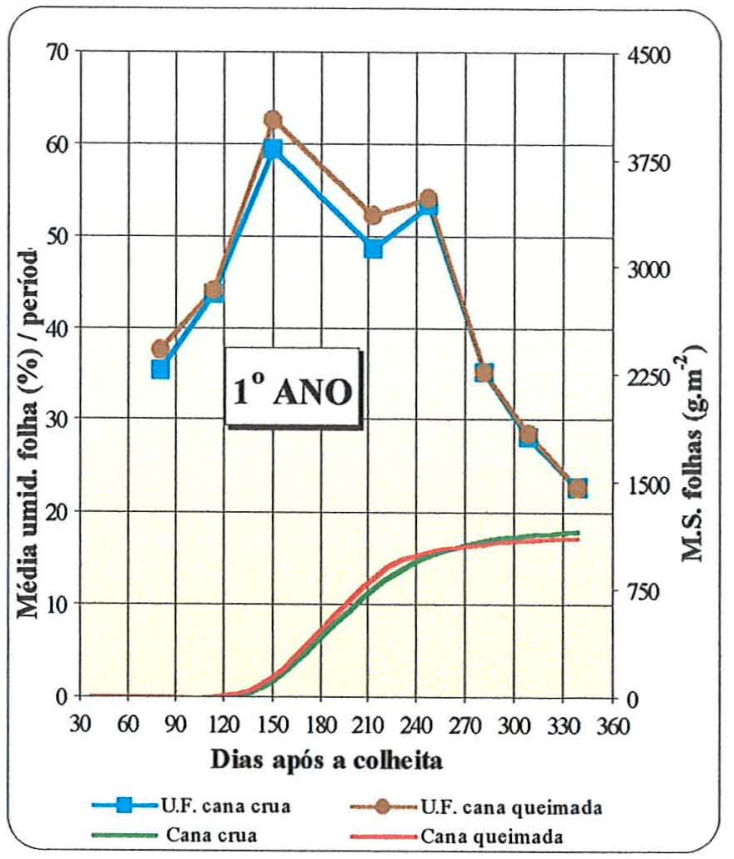

Figura 53-Umidade de folhas (\%) frente à matéria seca de folhas, no $1^{\mathrm{o}}$ e $2^{\mathrm{o}}$ ano de amostragem.

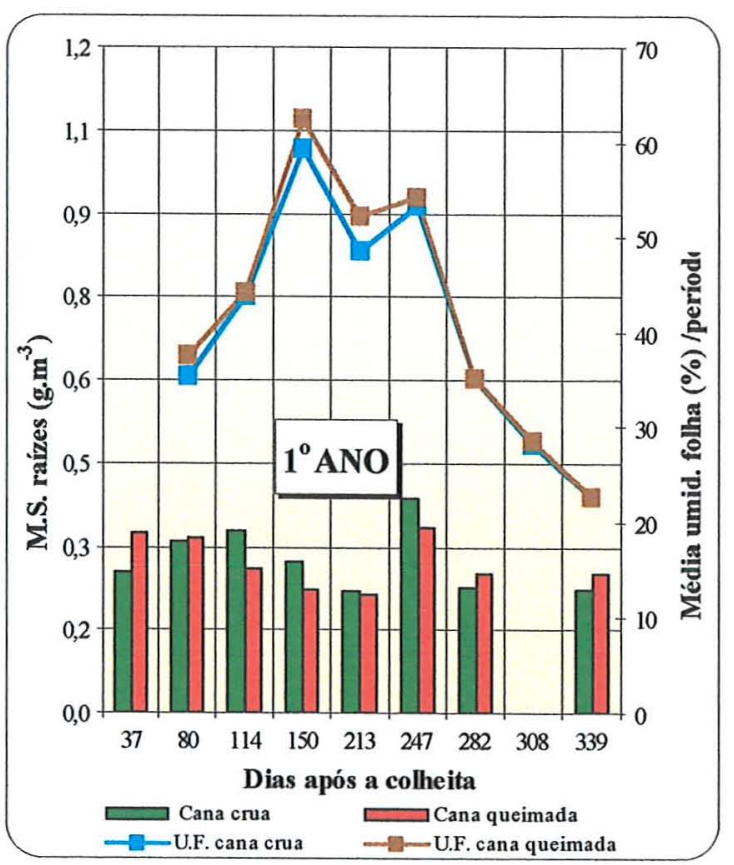

Figura 55-Umidade de folhas (\%) frente à matéria seca de raízes, no $1^{\circ}$ e $2^{\circ}$ ano de amostragem. 


\subsubsection{Umidade relativa do solo}
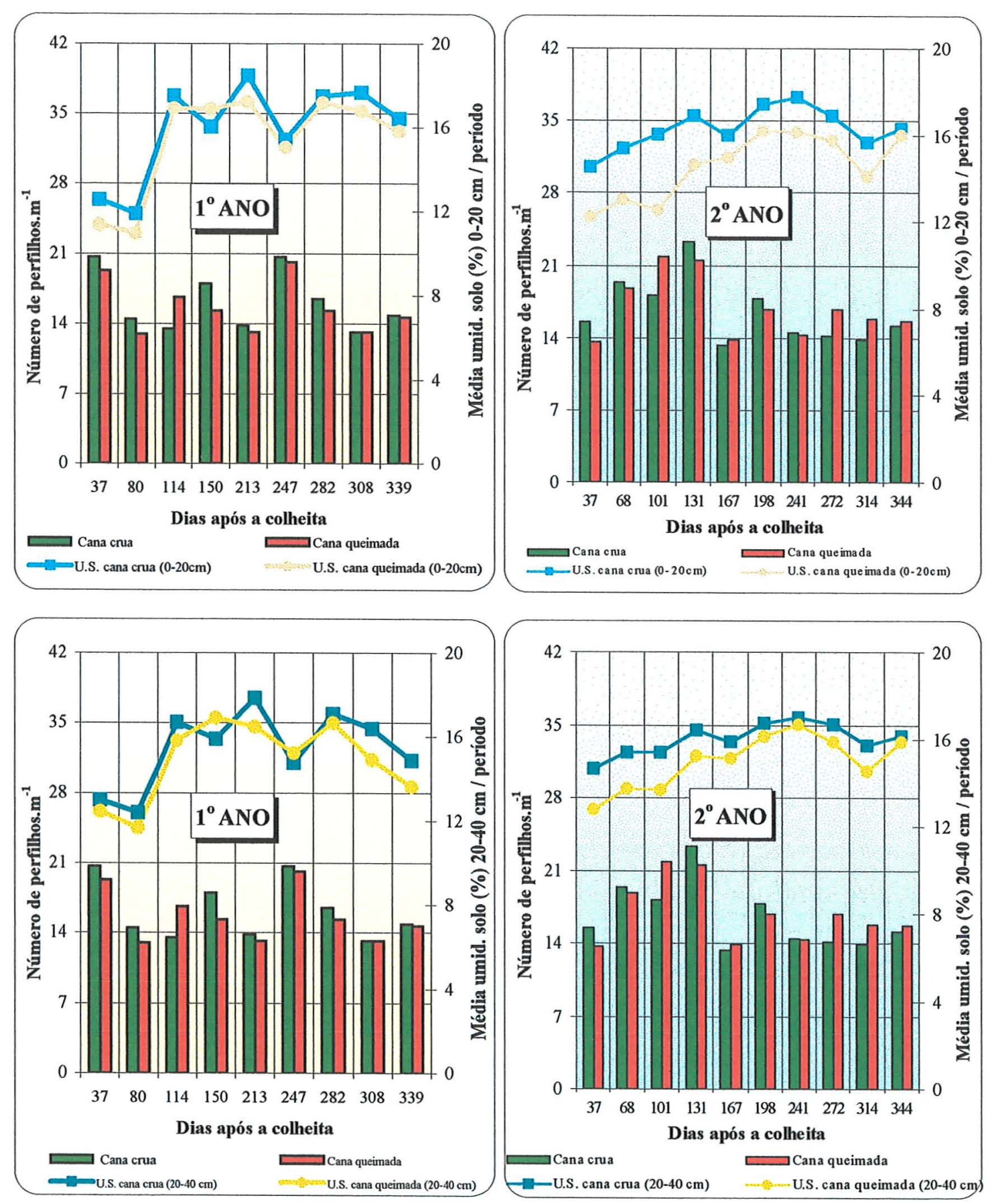

Figura 56 - Umidade relativa do solo (\%), em duas profundidades, frente ao número de perfilhos / $\mathrm{m}$ linear, no $1^{\underline{0}}$ e $2^{\underline{0}}$ ano de amostragem. 

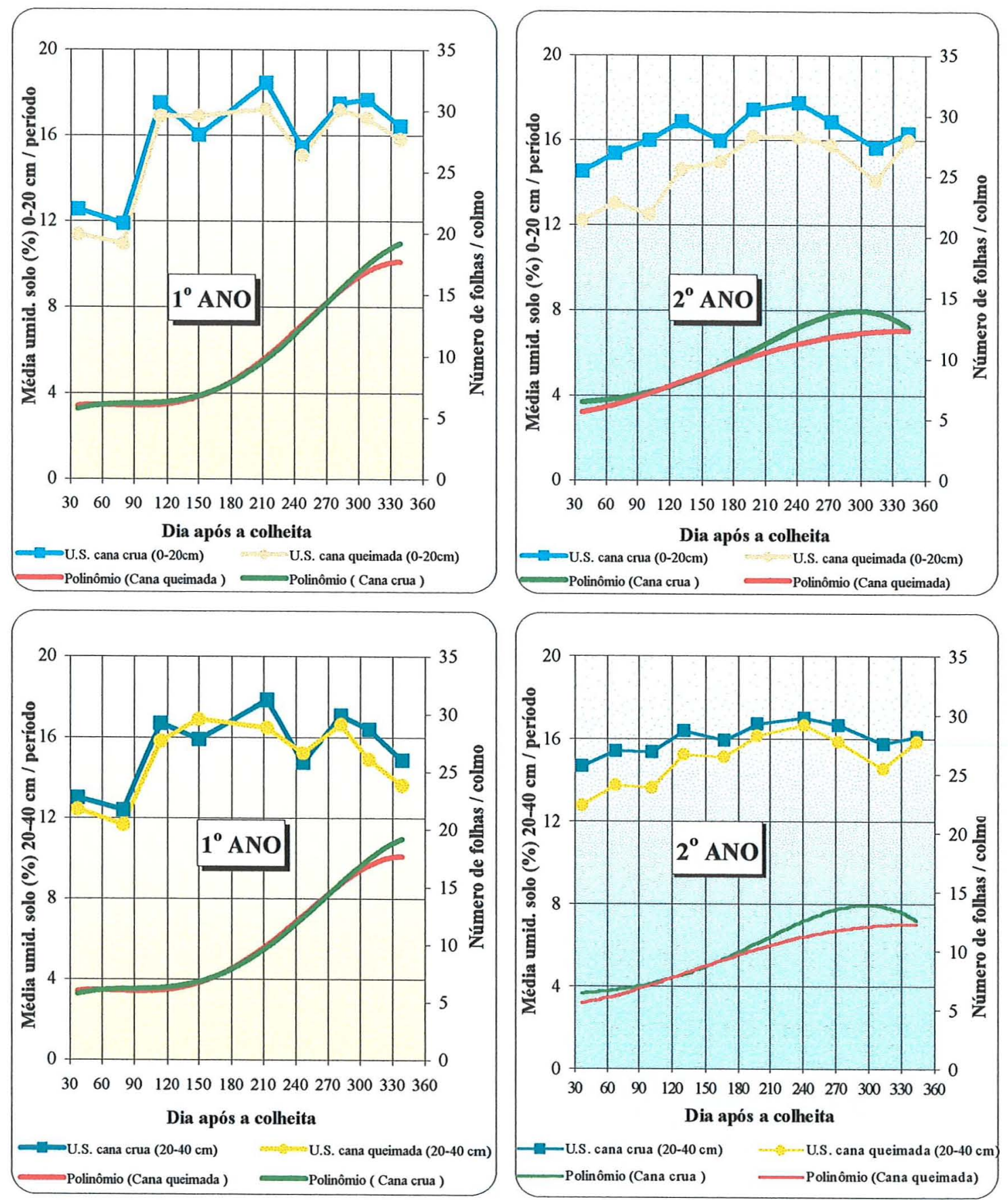

Figura 57 - Umidade relativa do solo (\%), em duas profundidades, frente aos número de folhas / colmo, no $1^{\circ}$ e $2^{\underline{0}}$ ano de amostragem. 

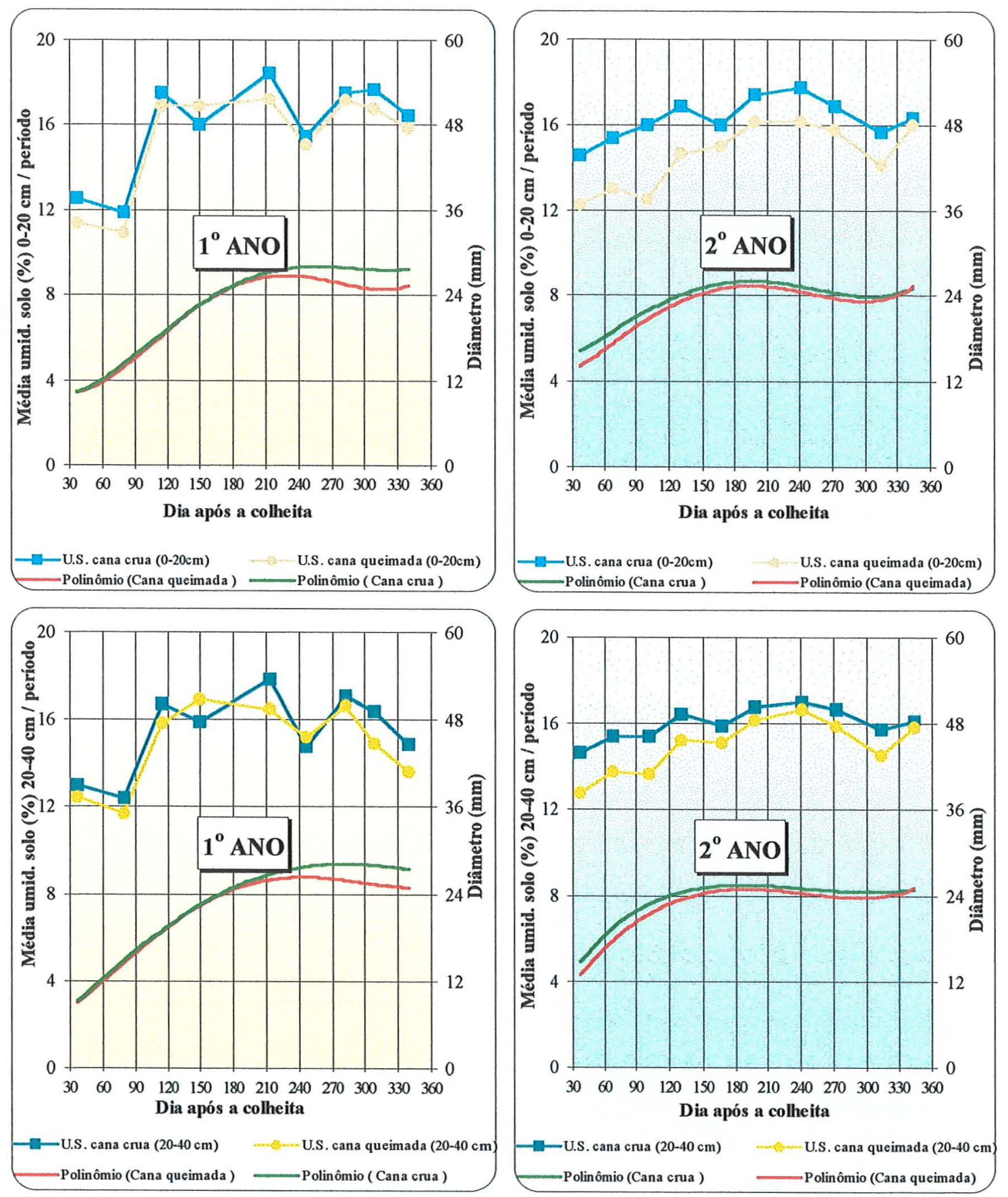

Figura 58 - Umidade relativa do solo (\%), em duas profundidades, frente ao diâmetro de colmos, no $1^{\underline{0}}$ e $2^{\underline{o}}$ ano de amostragem. 

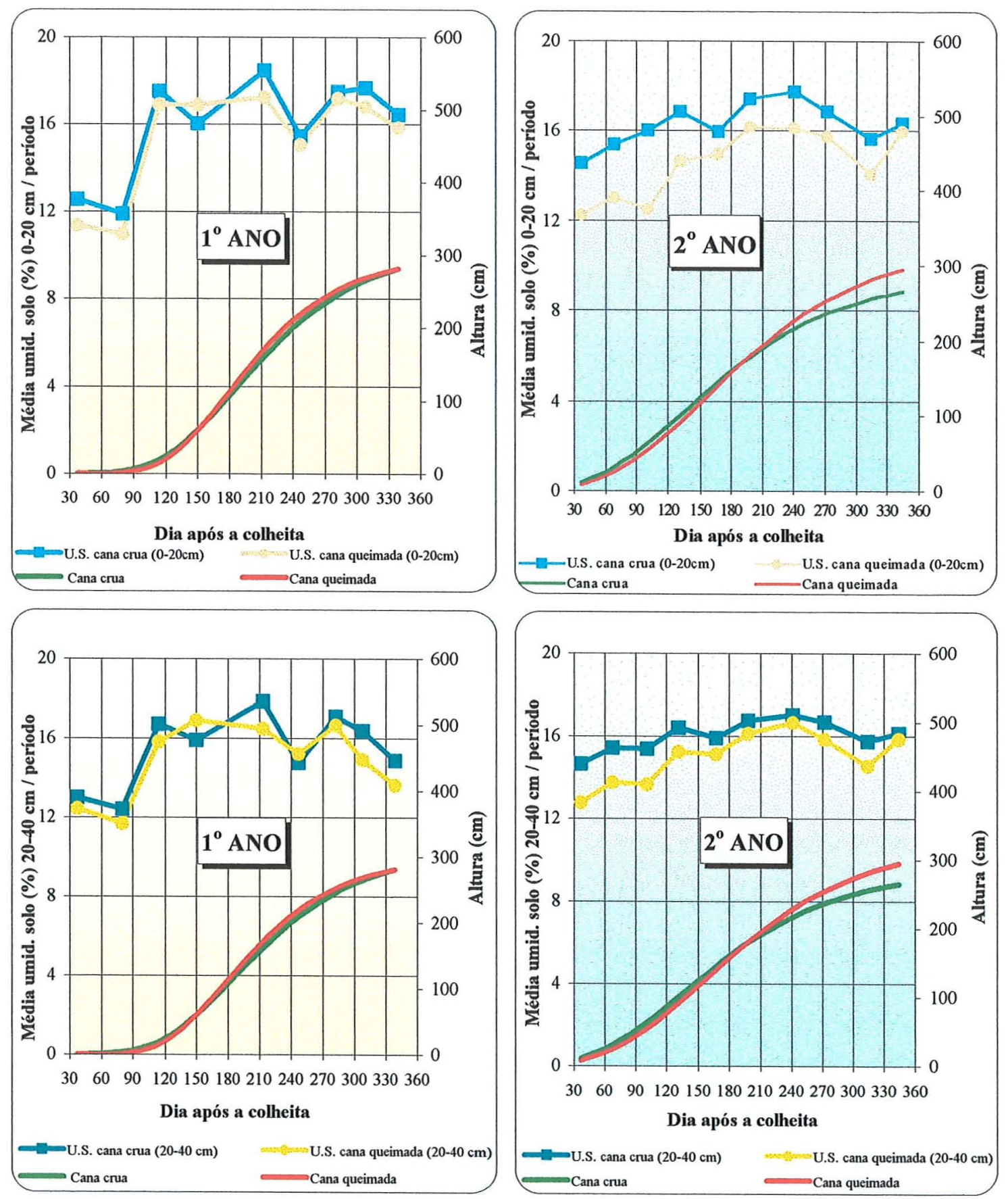

Figura 59 - Umidade relativa do solo (\%), em duas profundidades, frente à altura de plantas, no $1^{\underline{0}}$ e $2^{\underline{0}}$ ano de amostragem. 

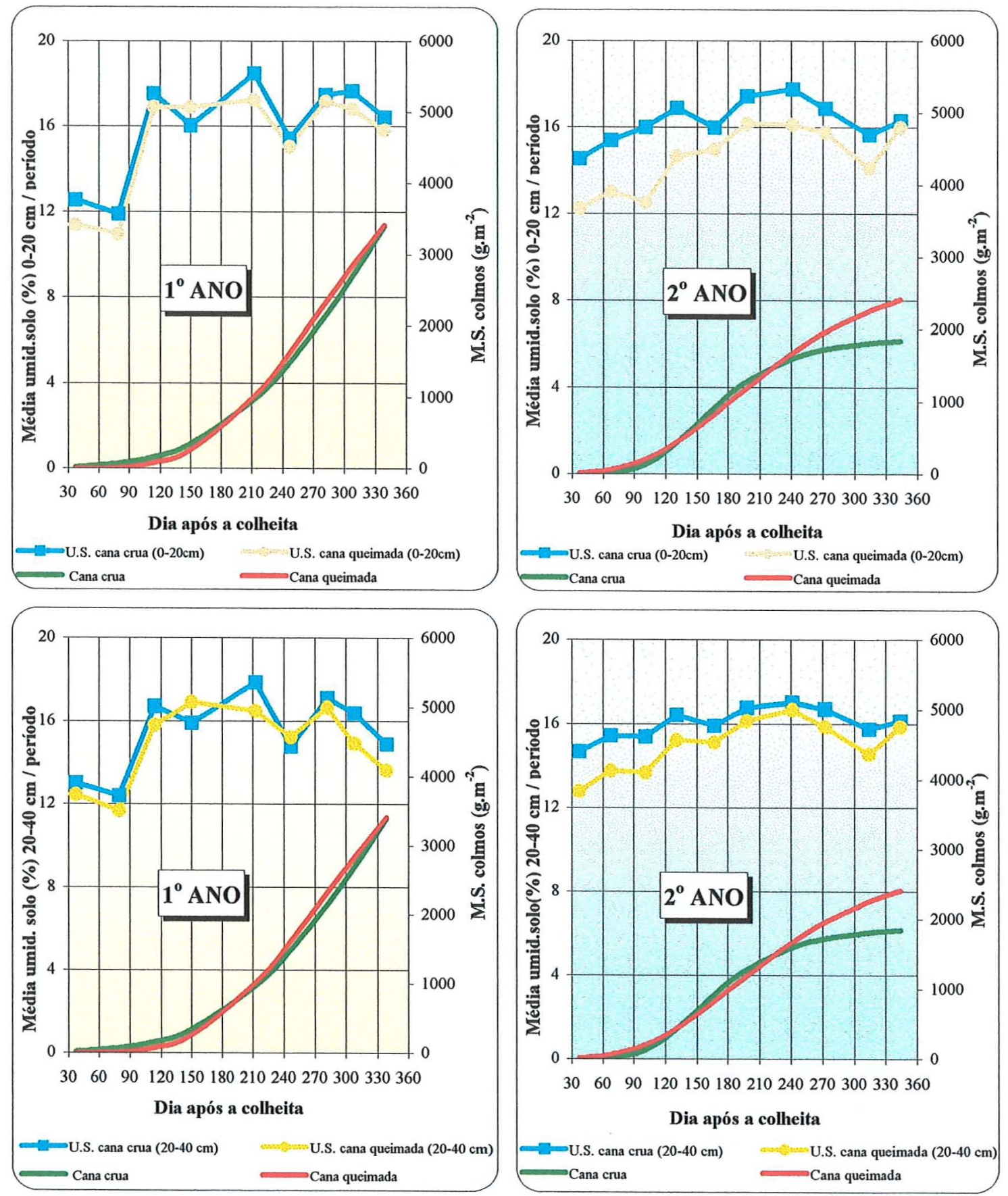

Figura 60 - Umidade relativa do solo (\%), em duas profundidades, frente à matéria seca de colmos, no $1^{\underline{o}}$ e $2^{\underline{o}}$ ano de amostragem. 

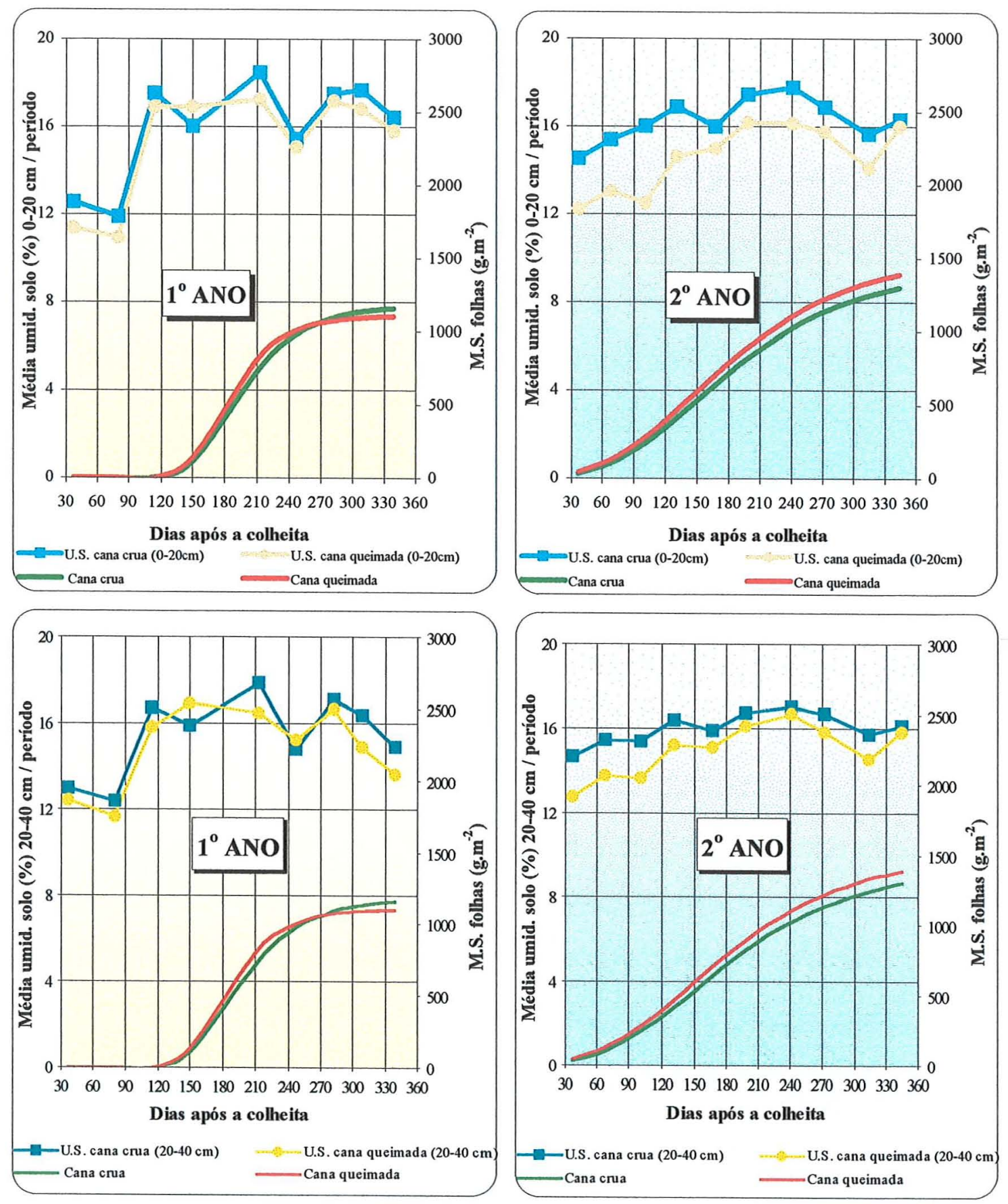

Figura 61 - Umidade relativa do solo (\%), em duas profundidades, frente à matéria seca de folhas, no $1^{\underline{0}}$ e $2^{\underline{o}}$ ano de amostragem. 

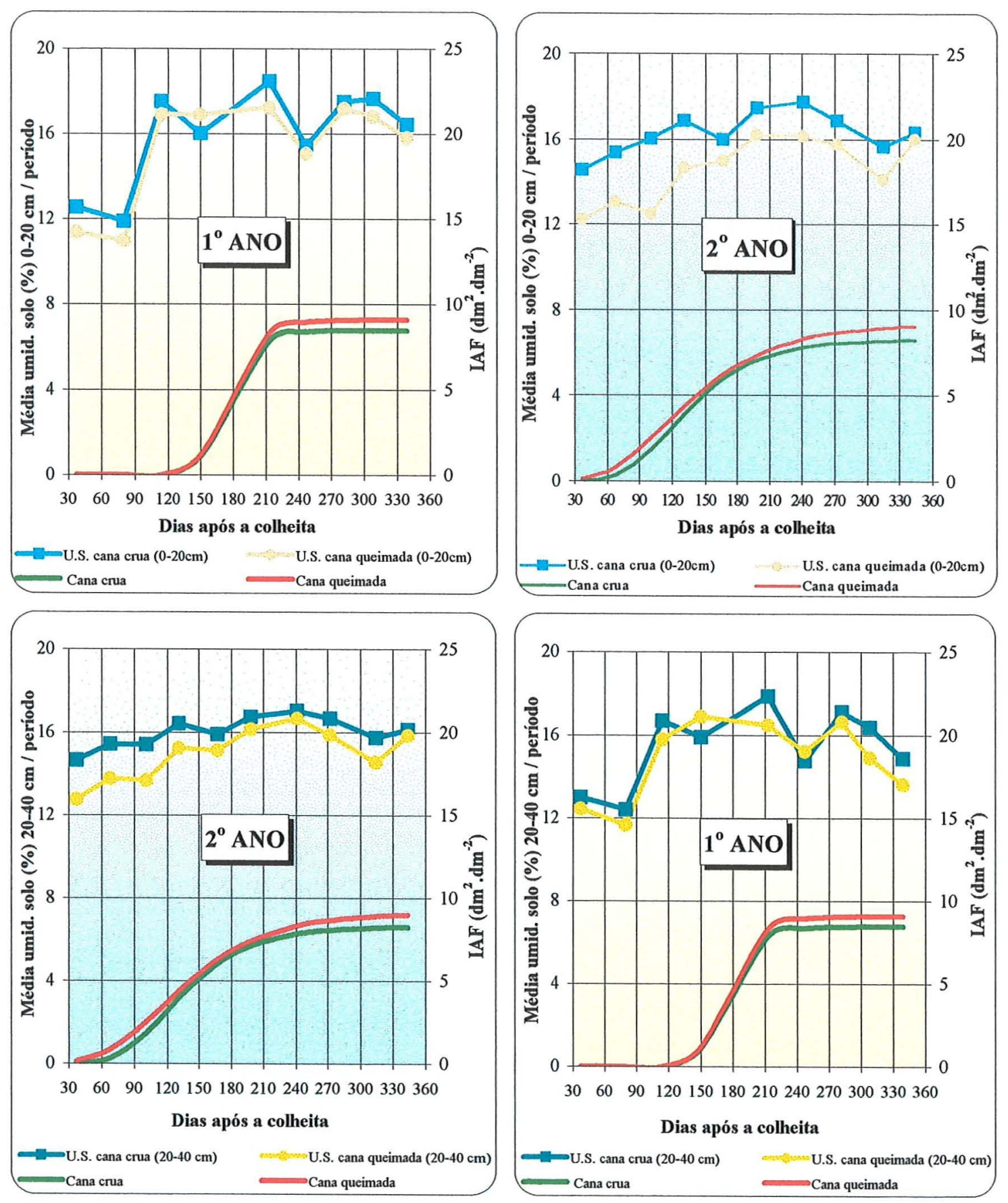

Figura 62 - Umidade relativa do solo (\%), em duas profundidades, frente ao IAF, no $1^{\circ}$ e $2^{\underline{0}}$ ano de amostragem. 

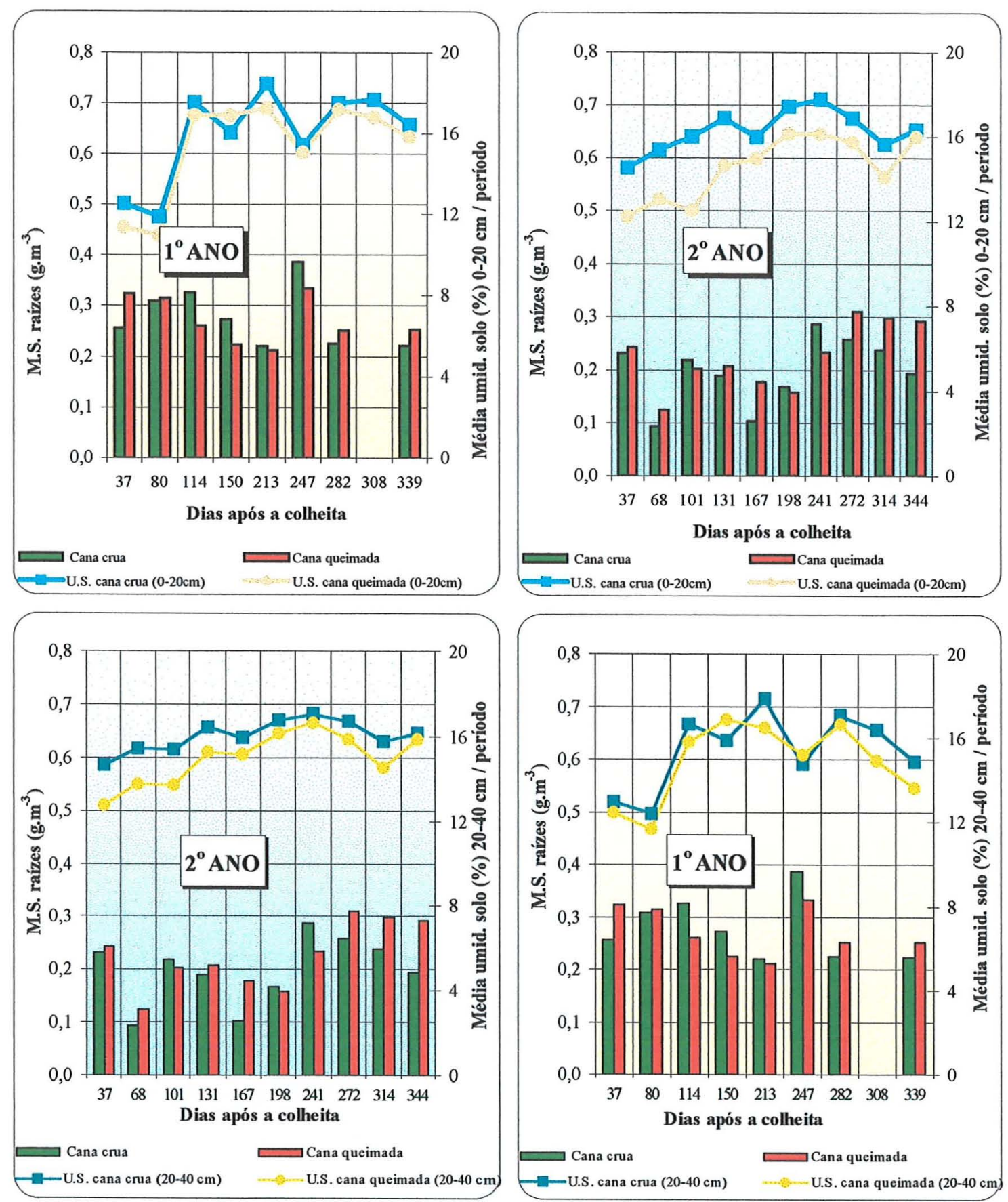

Figura 63 - Umidade relativa do solo (\%), em duas profundidades, frente à matéria seca de raízes, no $1^{\circ}$ e $2^{\circ}$ ano de amostragem. 


\subsection{Comparação dos dados climatológicos entre si}

\subsubsection{Temperatura}
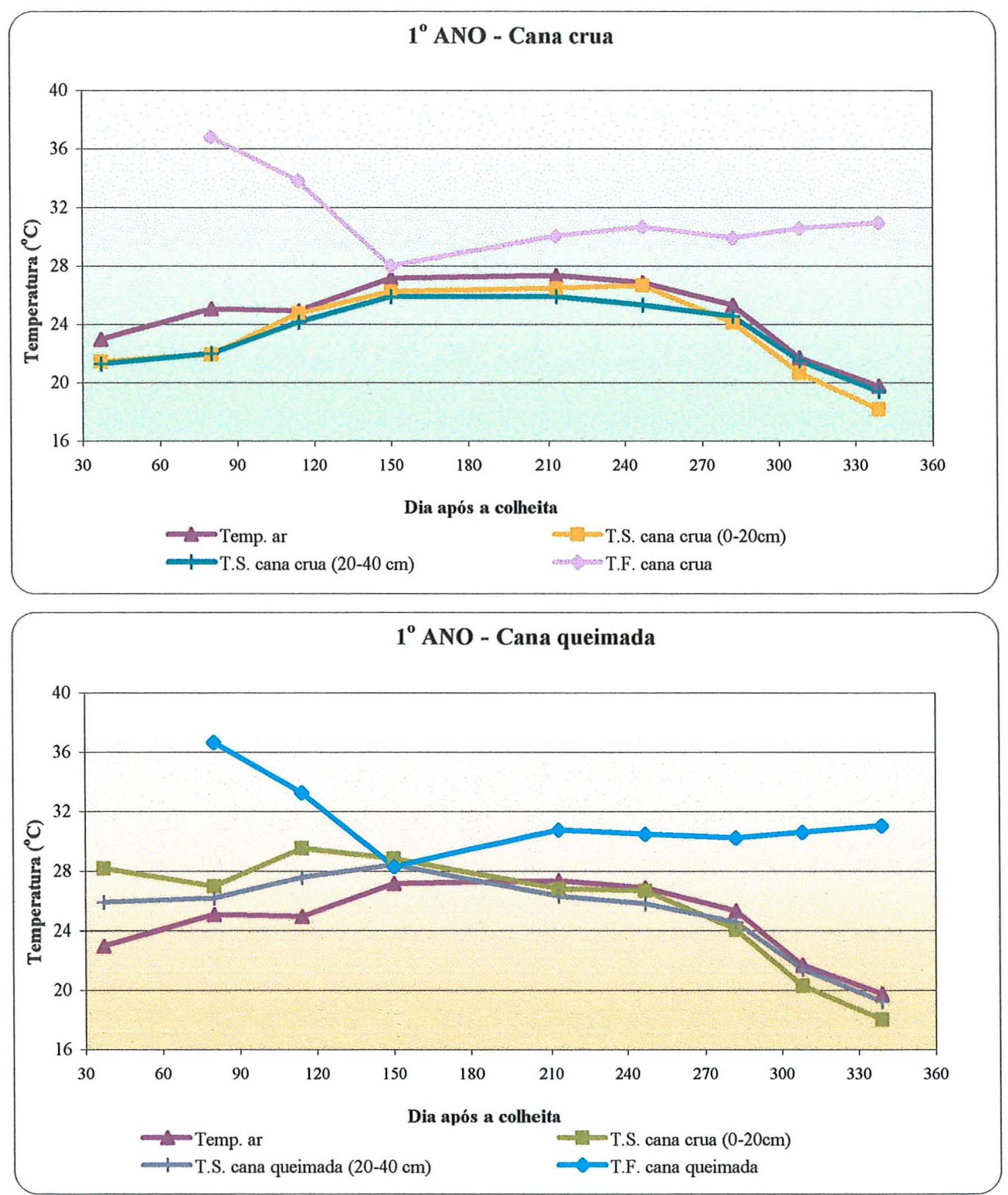

Figura 64 - Comparação entre temperatura do ar, da folha e do solo para cana crua e cana queimada no $1^{0}$ ano de amostragem. 

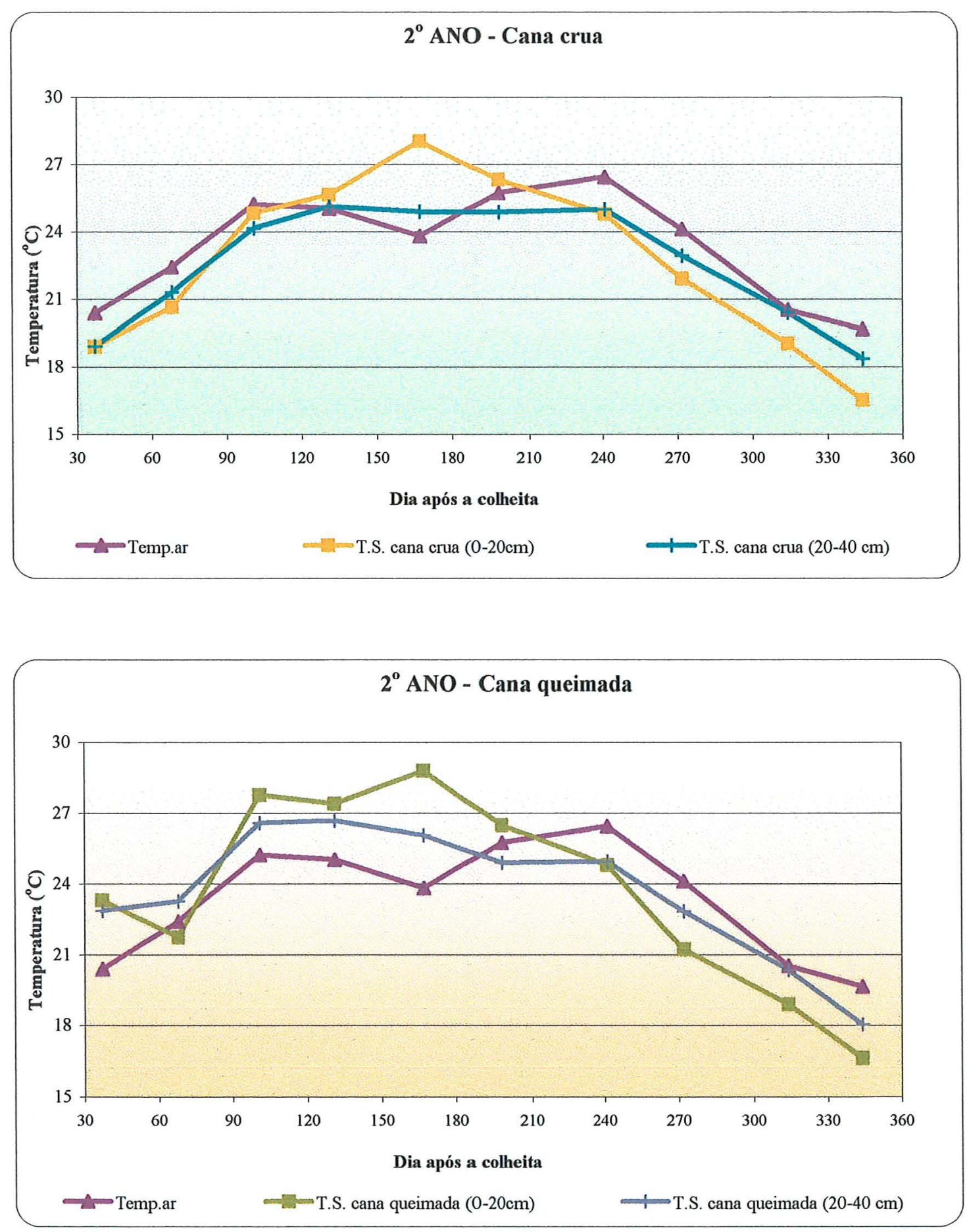

Figura 65 - Comparação entre temperatura do ar, da folha e do solo para cana crua e cana queimada no $2^{\underline{0}}$ ano de amostragem. 


\subsubsection{Umidade}
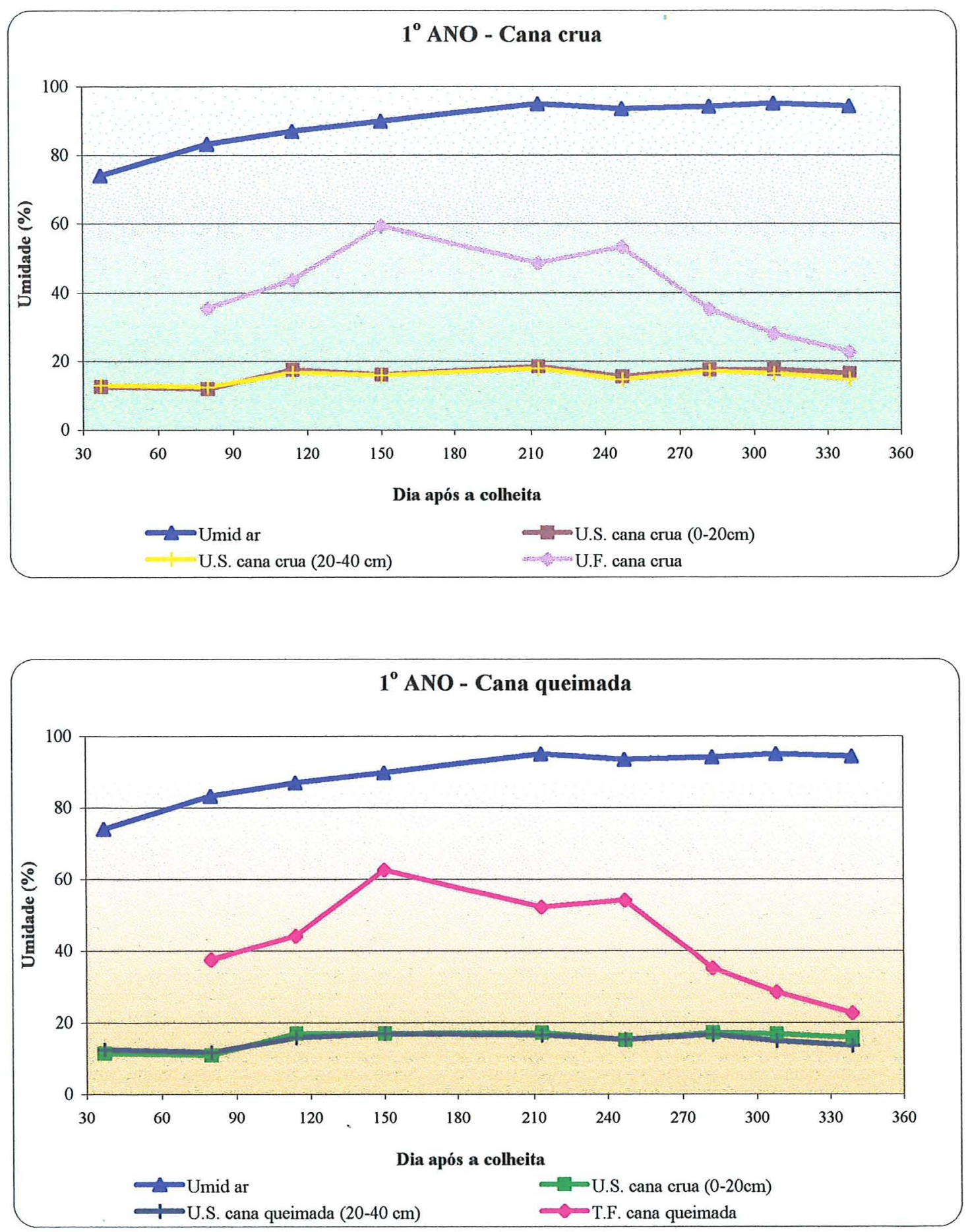

Figura 66 - Comparação entre umidade do ar, da folha e do solo para cana crua e queimada no $1^{\underline{o}}$ ano de amostragem. 

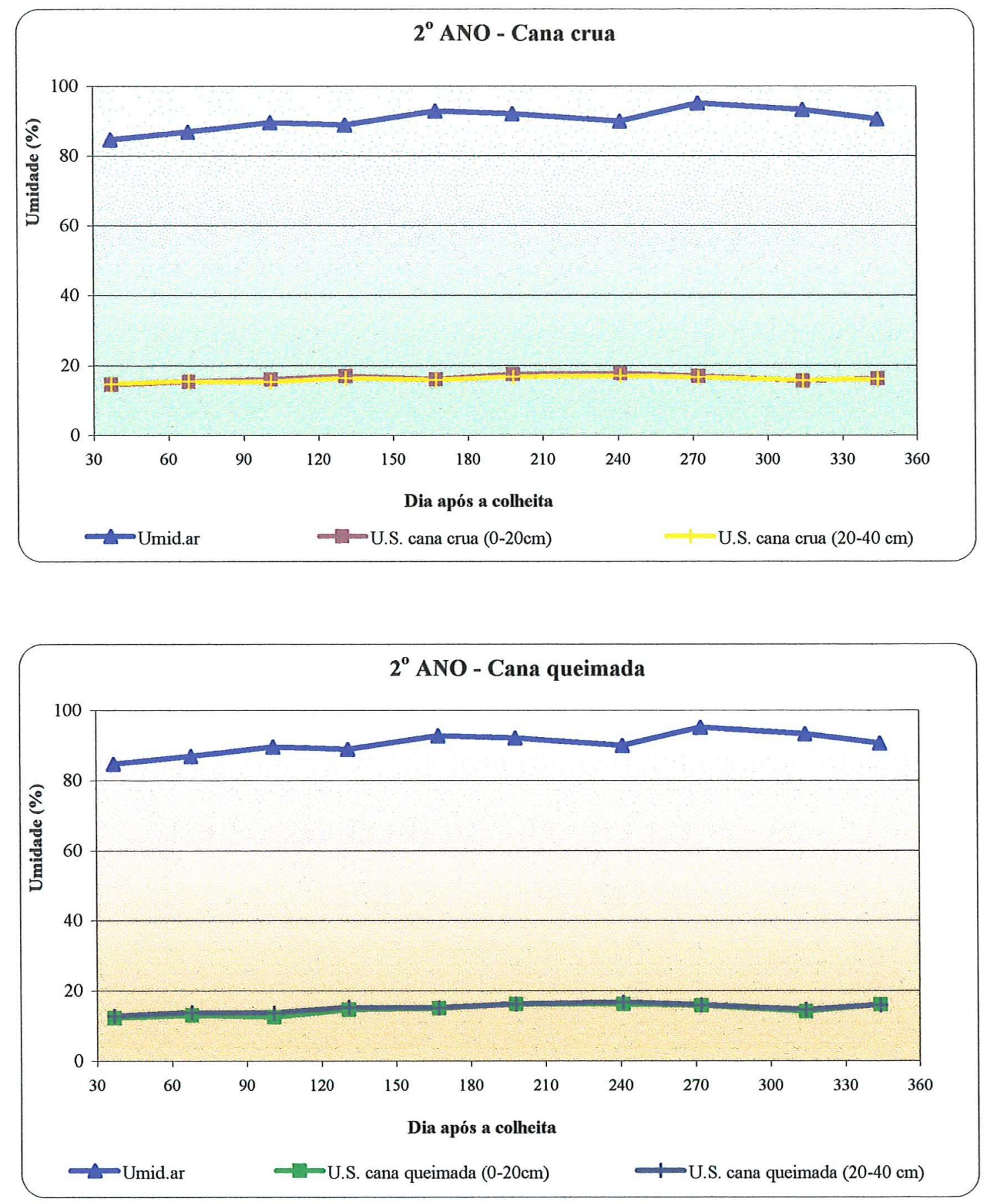

Figura 67 - Comparação entre umidade do ar e do solo para cana crua e queimada no $2^{\circ}$ ano de amostragem. 


\section{DISCUSSÃo}

\subsection{Número de perfilhos}

O perfilhamento da cana-de-açúcar normalmente apresenta uma estabilização a partir do número máximo de perfilhos-colmos ao longo do período de crescimento (Casagrande, 1991). Os dados do primeiro ano (Figura 3), mostraram uma variação sem que houvesse uma estabilização nítida após o perfilhamento máximo de aproximadamente 21 perfilhos, para cana crua e 20 perfilhos, para cana queimada. Por outro lado, houve uma tendência geral, no $2^{\circ}$ ano, de estabilização do número de perfilhos a partir do pico (131 DAC, para cana crua e $101 \mathrm{DAC}$, para cana queimada), concordando com os dados da literatura (Prado, 1988; Machado, 1987; Rocha, 1984).

Rocha (1984), encontrou para cana-planta um máximo de 26 colmos / metro linear, decaindo para 13 colmos / metro linear, enquanto que Prado (1988), utilizando a mesma variedade (SP 70-1143) como cana-soca, obteve 23 colmos como máximo e 13 colmos para o periodo de colheita; uma queda de $45 \%$.

Nos resultados obtidos no $2^{\underline{Q}}$ ano, houve uma queda de um máximo de 23,33 no número de perfilhos de cana crua, para 16,17, na última data de amostragem, representando um decréscimo de $35,03 \%$. Para cana queimada, a queda foi de 21,83 para 15,67 , ou seja, de $28,25 \%$.

Este trabalho mostrou uma queda menos acentuada do número de perfilhos que os da literatura, citados acima.

Nota-se uma maior brotação inicial no $1^{\underline{Q}}$ ano, tanto em cana crua como em cana queimada. A explicação para tal fato pode ser baseada nas Figuras 16, 33, 40 e 56, nas comparações entre os dados climatológicos e número de perfilhos, e nas Figuras 64 a 
67 , onde a temperatura do ar e do solo apresentam-se maiores no $1^{\underline{Q}}$ ano que no $2^{\underline{Q}}$ ano, ao contrário da umidade do ar e do solo que são menores no $1^{\mathrm{o}}$ ano que no $2^{\mathrm{o}}$ ano. A temperatura poderia estar favorecendo a melhor brotação no $1^{\underline{0}}$ ano ao se aproximar das condições ideais para esse periodo, com explica o trabalho de Blackburn (1984), que define a temperatura de $30^{\circ} \mathrm{C}$ como ideal para esse período.

Por outro lado, Thompson \& Du Toit (1965) e Gosnell (1968) afirmaram que o padrão de perfilhamento independe das condições hídricas. A cana crua não apresentou maior brotação no $1^{\underline{o}}$ ano, mesmo com maior quantidade de palha que favorece a retenção de umidade nas camada superficiais do solo, confirmado a literatura.

A comparação entre a rebrota da cana crua e da cana queimada, nos presentes experimentos, não mostrou diferenças significativas entre elas, ao contrário da suposição de alguns' autores, que indicaram, como desvantagem para a cana crua, a palha como causadora de dificuldade de rebrota, assim como Churchward \& Poulsen (1988) encontraram melhor perfilhamento e brotação de socas na cana crua.

Também a possibilidade aventada por Campos \& Marconato (1994) de que o sombreamento e diminuição da temperatura pela palha seria desfavorável ao brotamento da cana crua e por Silva (1997), de que poderia haver falhas de brotação como na Austrália, não se confirmaram com os dados aqui apresentados, mesmo no $2^{\underline{0}}$ ano, quando o acúmulo de palha supostamente é maior.

A quantificação da palha presente na cana crua no momento da rebrota seria uma forma de se definir mais claramente o quanto a presença da palha estaria influenciando na luminosidade, pois segundo Ripoli et al. (1991) a quantidade de palha deixada no campo é diferente para cada variedade. 


\subsection{Número de folhas}

$\mathrm{O}$ número de folhas apresentou um crescimento lento no $1^{\underline{o}}$ ano, até aproximadamente 150 DAC (Figura 4). Em uma segunda fase (correspondendo de 150 a $300 \mathrm{DAC}$ ), o crescimento foi rápido, atingindo seu máximo. A partir dos $280 \mathrm{DAC}$, crescimento estabilizou-se, tornando-se lento novamente em cana queimada e com uma diminuição menos acentuada em cana crua.

No segundo ano, as três fases características de crescimento não foram bem definidas, contudo, a diminuição do número de folhas ocorreu por volta dos 270 DAC.

O número médio de folhas / colmo foi, no $1^{\circ}$ ano, de 18,75 para cana crua $\mathrm{e}$ 17,83 para cana queimada e é superior ao $2^{\underline{0}}$ ano, sendo da ordem de 13,83 para cana crua e 12,83 para queimada. Entretanto, nos 2 anos de amostragem, observou-se um número superior ao encontrado por Machado et al. (1982) no fechamento do dossel (8 a 10 folhas / colmo) e ao relatado por Humbert (1968), que foi de 10 a 15 folhas / colmo.

Comparando-se a quantidade de folhas no $2^{\underline{9}}$ ano, entre cana crua e cana queimada, não se observaram diferenças significativas, apesar de haver certo distanciamento das curvas a partir dos 200 DAC, voltando a coincidir por volta dos 340 DAC. Esse período corresponde aos meses de fevereiro a julho, quando o acúmulo de graus-dia se estabiliza. Porém, não há grandes diferenças entre o $1^{\circ}$ e $2^{o}$ anos, que justifiquem uma influência devida aos tratamentos.

Analisando o número de folhas frente à graus-dia, observa-se que não há uma similaridade de tendências das duas curvas, como um todo, nos dois anos (Figura 17). O mesmo acontece com relação à temperatura de folha e à temperatura do solo (Figura 33 ).

Todavia, faz-se necessário detalhar a análise da temperatura do ar e do solo para que se compreenda melhor o comportamento das curvas de crescimento díspares nos dois anos.

Maniero (1980) encontrou altas correlações entre o acúmulo de graus-dia e o crescimento vegetal. Através da Figura 17, nota-se que no início do ciclo o acúmulo de graus-dia é mais rápido no $1^{\circ}$ ano que no $2^{\circ}$, contrário ao número de folhas. No decorrer do crescimento do número de folhas, no $1^{\circ}$ ano, há uma coincidência do período de 
crescimento acelerado com as datas onde a temperatura permaneceu acima de $25{ }^{\circ} \mathrm{C}$ (Figura 64), enquanto que no $2^{\circ}$ ano, nesse período, a temperatura foi menor. Já no final do ciclo, somente na última amostragem a temperatura esteve abaixo de $20{ }^{\circ} \mathrm{C}$ (temperatura base), nos dois anos, embora, no $2^{\circ}$ ano, o acúmulo final de graus-dia foi maior. Portanto, o número de folhas no final do ciclo independe da temperatura nesse período que já não exerce uma influência como em outras fases do ciclo, concordando com o relato de Glasziou et al. (1965).

No caso de temperatura do solo (Figura 33), houve uma diferença inicial entre cana crua e cana queimada, mas não se verificaram diferenças significativas no número de folhas entre os dois tratamentos, nos dois anos, mesmo a temperatura do solo de cana queimada permanecendo maior que $25^{\circ} \mathrm{C}$, do início até aproximadamente $270 \mathrm{DAC}$, e a de cana crua, somente a partir de $120 \mathrm{DAC}$ até $270 \mathrm{DAC}$.

Mongelard \& Mimura (1971) mostraram uma relação direta entre absorção de água e temperatura do ambiente radicular. No presente trabalho, as temperaturas de solo não são limitantes para a absorção de água, mas as tendências das curvas de umidade do ar (Figura 41) e do solo (Figura 57) frente ao número de folhas apresentam um certo paralelismo de umidade mais baixa com crescimento mais lento e de crescimento mais acelerado com umidade mais alta. Também, evidenciam uma tendência geral de no $1^{\circ}$ ano o crescimento ser mais lento no início e depois acelerado e no $2^{\underline{o}}$ ano, mais uniforme durante o ciclo. Já a curva de umidade das folhas não apresenta um aspecto que indique uma possível influência sobre o número de folhas, como mostra a Figura 49.

A umidade do solo é o principal fator que determina o déficit hídrico. Analisando-se a Figura 57 mais detalhadamente, nota-se que, no início do ciclo, no $1^{\circ}$ ano, a disponibilidade de água é menor que no início do $2^{0}$ ano, porém, sem que se defina como deficitária, pois não se tem uma idéia do balanço hídrico. Por outro lado, dos fatores analisados, somente as curvas de umidade do solo apresentaram comportamento semelhante ao comportamento da curva de crescimento do número de folhas, nas duas profundidades e nos dois tratamentos.

Do ponto de vista da comparação entre os tratamentos, mesmo não havendo diferenças significativas, observa-se que no $1^{\circ}$ ano, as curvas de crescimento do número 
de folhas de cana crua e de cana queimada estão muito próximas, durante todo o ciclo e, no $2^{-}$ano, estão mais afastadas; este comportamento se repete nas curvas de umidade do solo. Tal fato vem a reforçar a constatação de que a umidade influenciou mais no crescimento geral do número de folhas que a temperatura, como um todo.

\subsection{Diâmetro de colmos}

A análise das curvas de diâmetro de colmo (Figura 5) evidencia um crescimento acelerado no início do ciclo para os dois anos, mas mais intenso, inicialmente, no $2^{\underline{o}}$ ano. Posteriormente, observa-se uma ligeira queda. Em termos de números absolutos, houve maior queda no $2^{\mathrm{o}}$ ano.

Comparando-se os dados de cana crua e de cana queimada, constata-se que há significância, no $1^{\underline{0}}$ ano, aos 308 DAC (Tabela 2) e, no $2^{\underline{0}}$ ano, aos 241 DAC (Tabela 3), com valores maiores para cana crua; estas datas encontram-se na fase da curva, onde há queda discreta do diâmetro. Essa diminuição poderia estar relacionada com a constatação de que, sob menor luminosidade, os colmos são mais finos (Camargo, 1968), uma vez que em datas anteriores aos DAC de maiores diferenças de diâmetro, entre cana crua e cana queimada, nos dois anos, houve maior sombreamento em cana queimada que em cana crua, como mostram os dados de índice de área foliar (Figura $10)$.

A influência negativa do sombreamento sobre o diâmetro de colmos somente foi confirmada aos 241 DAC do $2^{\circ}$ ano (Tabela 5). Nesse caso, o número de folhas apresentou-se como um índice biométrico que se correlaciona significantemente com o diâmetro de cana crua $(-0,9690)$, mostrando que em cana crua o diâmetro é maior, quando há maior sombreamento. Entretanto, aos $308 \mathrm{DAC}$ do $1^{10}$ ano não houve essa correlação com o número de folhas.

Por outro lado, o diâmetro de colmos apresenta uma alta correlação inversa com temperatura de folhas (-1), para cana queimada, aos $308 \mathrm{DAC}$ do $1^{\circ}$ ano (Tabela 4 , 
Figura 26). Contudo, tal fato, por ser isolado e não haver dados de temperatura de folhas no $2^{\circ}$ ano, fíca difícil de analisar.

Embora haja diferenças significativas entre o diâmetro de colmos de cana crua e de cana queimada aos $37 \mathrm{DAC}$ do $2^{\circ}$ ano, não aparecem correlações significantes dos parâmetros analisados que expliquem esta constatação (Tabela 5). Já aos 241 DAC do $2^{\underline{o}}$ ano, o diâmetro correlaciona-se positivamente com a temperatura de solo nas duas profundidades analisadas $(0,9511$, para os dois tratamentos). Essa correlação indica que o aumento de temperatura do solo pode ter determinado os maiores valores de diâmetro de colmos de cana crua, embora, não necessariamente influenciando diretamente (Figura 34).

Quanto ao diâmetro de colmos comparado ao acúmulo de graus-dia (Figura 18), percebe-se que não há similaridade do comportamento das curvas como um todo, tanto no $1^{\circ}$ como no $2^{\circ}$ ano, apenas pode-se destacar que no início do $1^{\circ}$ ano $o$ crescimento acelerado inicial é similar.

Nos $1^{\circ}$ e $2^{\circ}$ anos de observação, verifica-se um desenvolvimento semelhante das curvas de umidade do ar e de diâmetro de colmo (Figura 42), embora não haja correlações significantes entre esse parâmetro biométrico e aquele fator ambiental. $\mathrm{O}$ mesmo ocorre com relação à umidade do solo (Figura 58). Por outro lado, com as medidas de umidade do ambiente foliar, não se notam correspondências.

\subsection{Altura de plantas}

A altura de plantas apresenta curvas de crescimento de forma sigmoidal, como relatado na literatura, tanto no $1^{\circ}$ como no $2^{\circ}$ ano. Entre o $1^{\circ}$ e o $2^{\circ}$ ano nota-se apenas uma diferença na fase inicial do $1^{\circ}$ ano, onde o crescimento é mais lento e prolongado que no $2^{-}$ano. Os dois tratamentos tornam-se significativamente diferentes somente no $2^{\underline{o}}$ ano, aos 37,314 e 344 DAC (Tabela 6).

A análise da Figura 19 mostra que, apesar de haver diferenças entre os $1^{\circ}$ e $2^{\underline{0}}$ anos, nas curvas de acúmulo de graus-dia, não há diferença na altura máxima atingida 
pela cana queimada, mas sim para a cana crua, no $2^{\circ}$ ano. Através da Figura 17 , nota-se que, no início do ciclo, o acúmulo de graus-dia é mais rápido no $1^{\circ}$ ano que no $2^{\circ}$, contrário ao número de folhas. Durante o crescimento da altura de plantas, no $1^{\circ}$ ano, não há uma coincidência inicial com a curva de acúmulo de graus-dia, uma vez que nesse periodo a primeira apresenta crescimento lento por um período maior. No $2^{\underline{0}}$ ano, ocorre o contrário, pois o crescimento da altura é mais acelerado no início que no $1^{\mathrm{o}}$ ano e a curva de graus-dia tem crescimento mais lento. $\mathrm{Na} 2^{\mathrm{a}}$ fase do ciclo, há coincidência das datas, onde a temperatura permanece acima de $25^{\circ} \mathrm{C}$ (Figura 64), com o crescimento mais acelerado nos dois anos. No $2^{\circ}$ ano, nesse período, a temperatura foi menor do que no $1^{\circ}$ ano e as curvas de crescimento de altura de plantas têm um aumento discretamente menor que no $1^{\circ}$ ano. Já no final do ciclo, o comportamento da curva de crescimento de cana queimada no $2^{\circ}$ é similar ao do das curvas dos dois tratamentos da curva do $1^{\circ}$ ano, enquanto que o comportamento da curva de cana crua tem seu crescimento diminuído, comparado com o $1^{\circ}$ ano.

Portanto, como no final do ciclo a temperatura já não exerce uma influência como em outras fases do ciclo (Glasziou et al., 1965) e a cana crua e a cana queimada só têm comportamentos diferentes no $2^{\circ}$ ano, mesmo a temperatura diminuindo igualmente nos dois anos, a temperatura do ar não tem influência sobre a diferença final apresentada na curva e na análise estatística entre os dois tratamentos.

Por meio da análise das Figuras $27,35,43,51$ e 59 , não se percebe uma clara relação, de uma maneira geral, entre a conformação das curvas de temperatura de folhas, temperatura do solo, umidade do ar, umidade de folhas e umidade do solo e a curva de altura de plantas.

A avaliação estatística entre a altura e parâmetros climatológicos, nas datas de diferenças significativas, evidencia a não correspondência desses itens entre si.

Aos $37 \mathrm{DAC}$ do $2^{9}$ ano, a cana crua apresentou valores significantemente mais altos que a cana queimada (Tabela 6). Nessa data de amostragem, não houve nenhuma correlação dos fatores analisados, que explicasse essa diferença. A partir das Figuras 27 e 35 , poder-se-ia supor, que a temperatura mais baixa do solo no $2^{\underline{0}}$ ano do que no $1^{\circ}$ estaria influenciando positivamente a cana crua, já que ela permanece mais baixa que a 
do solo de cana queimada. Contudo, essa constatação não está de acordo com a literatura (Glasziou et al., 1965), que coloca temperatura baixa como fator negativo para elongação do colmo, inicialmente. Por outro lado, a umidade do solo também pode estar influenciando nesse processo, uma vez que, inicialmente, ela é maior em solo de cana crua que no solo de cana queimada, e maior no $2^{\underline{0}}$ que no $1^{\mathfrak{Q}}$ ano, só ocorrendo diferença significativa no $2^{\circ}$ ano (Figura 59 ).

Aos 314 e 344 DAC, as correlações da cana crua com IAF e número de perfilhos (Tabela 7), respectivamente nas primeira e segunda datas, foram positivas $(0,9635$ e 0,9760$)$. Tal fato demonstra que a altura da cana crua foi menor, com maior presença de folhas e maior número de colmos. Todavia, a cana queimada apresentou uma correlação negativa, porém não significativa, da altura com a presença de folhas.

O menor desenvolvimento da altura nas últimas datas pode ser decorrente também do ataque de cigarrinhas, intensificado no segundo ano (Figura 15).

\subsection{Matéria seca de colmos}

Comparando-se as curvas de crescimento da matéria seca de colmos dos $1^{\circ} \mathrm{e}$ $2^{2}$ anos (Figura 7), observa-se que no $1^{\circ}$ ano ocorre um crescimento contínuo acelerado até a última data de amostragem, após um crescimento lento inicial para os dois tratamentos. No $2^{\underline{\underline{ }}}$ ano, ocorre 3 fases de crescimento nos dois tratamentos: inicial lento; acelerado chegando quase ao valor máximo final e uma estabilização até o final do ciclo. Tal fato confirma o relato de Machado (1987). Cabe ressaltar, que a curva de crescimento de cana queimada embora respeite esse comportamento, apresenta um maior crescimento que cana crua, na $3^{\underline{a}}$ fase.

Quanto à influência dos fatores climatológicos, nota-se através da Figura 20, que há uma similaridade maior entre curva de crescimento de matéria seca de colmos de cana crua e curva de acúmulo de graus-dias, no $2^{\circ}$ ano que no $1^{\circ}$. Em cana queimada, também há uma semelhança maior entre as duas curvas no $2^{\underline{Q}}$ ano, porém, bem menor que em cana crua. 
Maniero (1980) destaca que a ação da temperatura pode ser percebida através da acumulação de graus-dia. Esta influência é nítida em cana crua, quando as curvas que representam temperatura em graus-dia e crescimento em termos de matéria seca de colmos apresentam um paralelismo.

A partir da comparação entre as curvas de temperatura do solo e de acúmulo de matéria seca de colmos (Figura 36), verifica-se que, no $2^{\underline{0}}$ ano, nos períodos em que as curvas de temperatura do solo de cana crua e de cana queimada coincidem, as curvas de crescimento de matéria seca de colmos se distanciam. Portanto, parece não haver correspondência da temperatura do solo sobre matéria seca de colmos.

A análise das Figuras 44, 52 e 60 demonstra que o acúmulo de matéria seca pode estar relacionado com alguma influência por parte das umidades do ar e do solo, no $1^{\circ}$ e $2^{\circ}$ anos e da umidade de folha (mensurada somente no $1^{\circ}$ ano). Tal questão se justifica, quando se verifica que, no início do ciclo do $1^{\circ}$ ano, o crescimento é mais lento nos dois tratamentos e os valores de umidade do ar, da folha e do solo são menores que no início do $2^{\underline{0}}$ ano, onde o crescimento da matéria seca de colmos acelera-se.

A matéria seca de colmos apresentou valores significantemente maiores para cana queimada, no $1^{\circ}$ ano, aos 213 DAC. A observação do comportamento da curva desse parâmetro de crescimento frente às curvas dos fatores climatológicos, aos 213 DAC do $1^{\circ}$ ano, indica que somente as curvas de umidade do solo de cana crua e cana queimada, nas duas profundidades, são diferentes entre si, o que de tal forma, poderia justificar a diferença entre os dois tratamentos. Todavia, a análise de correlação entre esses fatores é que demonstra melhor se há ou não maior influência de um fator nessa data. Através da Tabela 10, verifica-se que as correlações obtidas entre a matéria seca de colmos, aos 213 DAC, com outros fatores, não indicaram significância.

No $2^{-}$ano, aos $37 \mathrm{DAC}$, os dados de matéria seca de colmos de cana crua foram significantemente maiores e, aos $272 \mathrm{DAC}$, foram os de cana queimada. As correlações para essas datas somente demonstraram significância aos 37 DAC com o IAF, para cana queimada $(0,9862)$, e com matéria seca de folhas, para cana crua $(0,9672)$ (Tabela 11). Como não há coerência nessas correlações, não se pode afirmar que algum fator biométrico esteja provocando diferença estatística aos $37 \mathrm{DAC}$. 
Não havendo correlações significativas entre matéria seca de colmos e parâmetros climatológicos, recorre-se à avaliação das Figuras 36 e 60 . Essa avaliação leva a supor que a umidade do solo estaria influenciando mais que a temperatura do solo aos $37 \mathrm{DAC}$, pois a diferença entre suas curvas para cana crua e cana queimada é maior no $2^{\circ}$ ano em relação ao $1^{\underline{o}}$ ano, para umidade do solo do que para temperatura. Vale lembrar que a presença de palha deixada pela colheita de cana crua favorece $o$ aumento da umidade do solo (Rozeff, 1995b).

A identificação mais objetiva de quais fatores climatológicos e de quais fatores biométricos estudados são preponderantes para favorecer o desenvolvimento da matéria seca de colmos de cana queimada, ou ainda, prejudicar o de cana crua aos 37 DAC, não é possível com esses dados. Poder-se-ia, porém levantar a hipótese de que cana crua está sendo favorecida inicialmente no $2^{\underline{0}}$ ano, pela maior umidade do solo em decorrência da presença de palha.

Aos 272 DAC do $2^{\circ}$ ano, também não se encontram correlações significativas e a análise dos fatores que podem estar contribuindo para provocar diferenças entre os dados de cana crua e cana queimada é dificultada. A temperatura do ar em graus-dia (Figura 20) é que apresenta maior correspondência à curva de cana crua, como já foi dito anteriormente, por isso, pode ter maior influência que os outros fatores, nessa data. A temperatura do solo (Figura 36) apresenta coincidência de curvas para os dois tratamentos, nessa data. A umidade do ar tem um aumento relativo à data anterior que não se reflete na umidade do solo, que diminui ligeiramente (nas duas profundidades $\mathrm{e}$ nos dois tratamentos), como se percebe na Figura 67. Como a queda da umidade do solo é praticamente a mesma para os dois tratamentos e a curva de crescimento de matéria seca de colmos de cana queimada continua crescendo, não há diferença de comportamento da temperatura de solo de um dos dois tratamentos que justifique a diferença.

Então, a constatação de campo, que a presença de cigarrinha poderia estar causando o menor desenvolvimento da cana crua é viável, uma vez que, não se encontraram fatores biométricos e climatológicos, para a data de 272 DAC no $2^{\circ}$ ano, que justificassem o menor desenvolvimento de cana crua. Na Figura 15 pode-se 
confirmar essa suposição quando se observa que a maior presença de cigarrinha ocorre no mês de abril, o mesmo da amostragem.

\subsection{Matéria seca de folhas}

A curva de crescimento de matéria seca de folhas apresentou um desenvolvimento diferente para o $1^{\circ}$ e o $2^{\circ}$ anos (Figura 8). De forma contrária às curvas de crescimento de matéria seca de colmos (Figura 7), no $1^{\circ}$ ano, a curva de matéria seca de folhas demonstrou uma maior estabilização na $3^{\underline{a}}$ fase de crescimento.

No $1^{\underline{o}}$ ano, o crescimento das folhas foi mais lento inicialmente do que no $2^{\circ}$ ano e, somente após os 120 DAC, houve aceleração. Os trabalhos de literatura relatam que inicialmente utilizam-se reservas da soqueira para o crescimento da cultura, até que se estabeleça o aparelho fotossintético e a planta passe a assimilar a energia necessária para seu crescimento. Portanto, o desenvolvimento inicial das folhas vai depender do quanto de reservas a soqueira apresenta.

Em seguida à brotação inicial das folhas, a interação com o meio ambiente torna-se mais importante, então recorre-se à análise das figuras que representem a comparação da temperatura e de umidade com matéria seca de folhas.

A Figura 21 evidencia que o acúmulo de graus-dia atinge $\pm 500^{\circ} \mathrm{C}$ já aos 120 DAC, data aproximada onde começa a aceleração do crescimento da matéria seca de folhas. Em contraste, no $2^{\circ}$ ano, o acúmulo de graus-dia atingiu $\pm 400^{\circ} \mathrm{C}$ aos $130 \mathrm{DAC}$, enquanto que o crescimento da matéria seca apresentava-se acelerado desde o início do ciclo. Todavia, as Figuras 64 e 65 evidenciam que as temperaturas médias iniciais foram maiores no $1^{\circ}$ que no $2^{-}$ano. Como as temperaturas iniciais não estiveram acima do limite superior de $35^{\circ} \mathrm{C}$, estabelecido por Falconier \& Bassereau (1975) para redução do crescimento, não se pode afirmar que foi a temperatura que prejudicou o crescimento inicial do $1^{\underline{Q}}$ ano em relação ao do $2^{\circ}$.

Por outro lado, da análise das curvas de temperatura do solo frente à matéria seca de folhas (Figura 37), extrai-se que a temperatura do solo é maior no início do ciclo 
do $1^{\underline{o}}$ ano que no do $2^{\underline{Q}}$, repetindo o comportamento de graus-dia, ou seja, sem possível correlação com a curva de crescimento da matéria seca de folhas, em termos de comportamento gráfico.

Quanto à temperatura de folhas no $1^{\circ}$ ano (Figura 29), há uma queda no início do ciclo e uma ligeira subida e estabilização posterior. Da mesma forma, ocorre uma coincidência do momento que ela deixa de cair com a aceleração do crescimento de matéria seca das folhas. Contudo, há dados para se comparar com o $2^{\circ}$ ano.

Em termos de umidade, evidencia-se na Figura 45 que no $1^{\frac{0}{2}}$ ano de amostragem, a umidade do ar é menor no início do $2^{\underline{0}}$ ano, assim como a umidade do solo (Figura 61) e a umidade da folha (Figura 53) inicialmente são baixas no $1^{\circ}$ ano. Portanto, é possivel destacar que a diferença de umidade entre o $1^{\underline{O}}$ e o $2^{\circ}$ ano é o fator determinante para o comportamento inicial das folhas, em termos de matéria seca de folhas, confirmando a importância da disponibilidade de água nos momentos iniciais da cultura (Imman-Bamber, 1986).

A análise estatística das diferenças entre cana crua e cana queimada (Tabela 12) não demonstrou significância no $1^{\underline{0}}$ ano, havendo no $2^{\underline{o}}$ ano diferenças aos 37 e 272 DAC, com valores maiores para cana crua na $1^{\mathrm{a}}$ data e para cana queimada, na $2^{\mathrm{a}}$. Em termos de correlações aos $37 \mathrm{DAC}$, houve significância apenas com parâmetros biométricos: com o IAF, para cana queimada $(0,9654)$, e com matéria seca de folhas, para cana crua $(0,9623)$ (Tabela 13). No $2^{\circ}$ ano não foi encontrada nenhuma correlação, tanto com parâmetros biométricos, como com fatores climatológicos. Como não há coerência nessas correlações, não se pode afirmar que algum fator biométrico esteja provocando a diferença estatística aos 37 DAC. Cabe ressaltar que no $2^{-}$ano as análises estatísticas foram similares às análises para matéria seca de colmos.

As diferenças estatísticas no $2^{\circ}$ ano podem ser melhor compreendidas por meio das Figuras 37 e 60, onde se supõe que a umidade do solo estaria influenciando de uma forma mais contundente que a temperatura do solo aos 37 DAC, pois a diferença entre as curvas de temperatura do solo de cana crua e de cana queimada no $2^{-}$ano é maior a entre as curvas de umidade do solo. 
Como não há medidas de umidade na palhada, não se pode definir objetivamente o quanto ela influencia no desenvolvimento da cana crua, mas como há medidas de umidade do solo de cana crua e cana queimada e encontra-se mais umidade no solo de cana crua, pode-se afirmar que há maior disponibilidade de água para cana crua. Rozeff (1995b) pode ser citado novamente, como em matéria seca de colmos, quando relata que a presença de palha deixada pela colheita de cana crua favorece o aumento da umidade do solo. Então, a maior umidade do solo presente na palha deixada no campo favoreceria o crescimento inicial, no $2^{\circ}$ ano, de matéria seca de folhas de cana crua, da mesma forma que no crescimento da matéria seca de colmos.

Aos 272 DAC do $2^{-}$ano, a temperatura do ar em graus-dia (Figura 21) evidenciou maior correspondência à curva de cana crua, por isso pode ter maior influência que os outros fatores nessa data. Da mesma forma, houve coincidência das curvas de temperatura do solo (Figura 37) com as curvas de matéria seca de colmos para os dois tratamentos, nessa data.

A Figura 67 mostra que a curva de umidade do solo para os dois tratamentos e para as duas profundidades diminuiu ligeiramente, não refletindo o mesmo aumento da umidade do ar relativo à data anterior e a Figura 61 mostra que a queda da umidade do solo é praticamente a mesma para os dois tratamentos. Portanto, não há diferença de comportamento das curvas de umidade de solo dos dois tratamentos que possa indicar o porquê da diferença entre tratamentos nessa data.

A análise da Figura 15, evidenciando que a maior presença de cigarrinhas ocorre no mês de abril do $2^{\underline{Q}}$ ano, coincidindo com a data de 272 DAC onde a cana crua desenvolve-se menos que a cana queimada, poderia cobrir a lacuna causada pela falta de explicação dos outros parâmetros considerados. 


\subsection{Matéria seca da parte aérea}

A matéria seca da parte aérea alterou-se pouco de um ano para outro em termos de quantidade final, quando se somam a matéria seca de colmos com a de folhas. Já a proporção entre matéria seca de colmos e de folhas variou pouco, nos dois tratamentos, de um ano para outro, sendo que no final do ciclo, há uma proporção em torno de $30 \%$ de matéria seca de folhas no $1^{\circ}$ ano e de $40 \%$ no $2^{\circ}$ ano. Por outro lado, a produção de colmos é maior no $1^{\circ}$ ano que no $2^{\mathfrak{Q}}$ e a de folhas, maior no $2^{\circ}$ que no $1^{\circ}$.

$\mathrm{Na}$ comparação entre cana crua e cana queimada, a presença de folhas é maior em cana queimada, inicialmente, e, na segunda metade do ciclo, a proporção é semelhante em cana crua e cana queimada, nos dois anos de amostragem.

\section{8 Índice de área foliar}

A partir da observação da Figura 10, verifica-se a ocorrência de três fases distintas nas curvas de crescimento de IAF, tanto no $1^{\circ}$ como no $2^{\circ}$ ano, para cana crua e cana queimada.

No $1^{\circ}$ ano, o crescimento é muito pequeno, mantendo-se dessa forma até os 150 DAC, aproximadamente. No $2^{\mathfrak{Q}}$ ano, essa primeira fase de crescimento lento é bem mais curta, até os $80 \mathrm{DAC}$. A segunda fase (de crescimento rápido), ocorreu no $1^{\mathrm{o}}$ ano, dos 150 aos 220 DAC, e no $2^{\circ}$ ano, dos 80 aos 200 DAC. A terceira fase (estabilização) ocorreu a partir dos 220 e $200 \mathrm{DAC}$, respectivamente, nos $1^{\circ}$ e $2^{\circ}$ anos.

O comportamento das curvas de crescimento está de acordo com Machado et al. (1982), embora no $2^{\circ}$ ano, no início da curva, o período de crescimento lento é menor.

Por outro lado, Yoon (1971) considera que as três fases de crescimento são: $1^{a}$ fase- muito rápida; $2^{\underline{a}}$ fase - estacionária e $3^{\underline{a}}$ fase - queda. Esse padrão não ocorre nesse trabalho, embora, no $2^{-}$ano quase não haja uma fase lenta, no início. A queda numa $3^{a}$ 
fase poderia ocorrer se o ciclo fosse maior, já que o autor verificou essas fases em ciclos de 1,5 anos e nesse trabalho o ciclo foi de 1 ano.

O comportamento das curvas de crescimento de IAF é muito parecido com o das curvas de crescimento da matéria seca das folhas, apenas com uma estabilização dos valores mais marcante na $3^{\underline{a}}$ fase do ciclo de IAF, no $2^{\underline{o}}$ ano de amostragem. Portanto, é possivel constatar a mesma influência dos parâmetros climatológicos com a matéria seca de folhas no IAF, em termos gerais de comportamento das curvas.

Através da observação das Figuras 22, 30, 38, 46, 54 e 62, determinam-se quais são os fatores climatológicos que mais influenciam nas diferenças de comportamento geral das curvas de IAF, nos $1^{\underline{o}}$ e $2^{\underline{o}}$ anos. Como o comportamento dos dois tratamentos, de maneira geral, nos dois anos, é similar, não se distingue um do outro.

A umidade do ar e do solo, por serem menores no início do ciclo, podem estar determinando uma maior influência sobre o crescimento mais lento do IAF no início do $1^{\circ}$ ano, comparado ao $2^{\circ}$ ano, que a temperatura do ar e do solo, como em matéria seca de folhas. Já a umidade e a temperatura de folhas não são citados no $2^{\circ}$ ano.

Os valores máximos de IAF aqui encontrados são: 11,5611 e 12,5526, respectivamente para cana crua e para cana queimada, aos 247 DAC do $1^{\circ}$ ano; no $2^{9}$ ano de 9,8934, aos 198 DAC para cana crua, e 10,2457, aos 344 DAC para cana queimada. Tais valores são considerados altos, baseando-se em Irvine \& Benda (1980), que definem IAF variando entre 2 e 8 ; San Jose \& Medina (1970) obtiveram IAF máximo de 7,6 e Yoon (1971), de 5. Contudo, Chang (1968) encontrou valores ótimos ao redor de 9 a 12, caso em que se incluem os dados aqui citados.

Os IAF médios obtidos nesse trabalho foram mais altos no $2^{\circ}$ ano $(5,1986$ para cana crua e 5,6374 para cana queimada) que no $1^{\circ}$ ano $(4,8211$ e 5,1689$)$, comportamento similar à matéria seca de folhas (Figura 8) e contrastante com a matéria seca de colmos (Figura 7), maior no $1^{\underline{0}}$ ano, que no $2^{\underline{\underline{ }}}$ ano.

Aos $247 \mathrm{DAC}$ do $1^{\circ}$ ano, o IAF já atingia seu valor máximo, enquanto que o crescimento em termos de matéria seca de colmos continuava a ocorrer para os dois tratamentos. Em contraste, no $2^{\underline{Q}}$ ano, em cana crua, a matéria seca de colmos 
estabilizou-se a partir do IAF máximo (aos 198 DAC) e em cana queimada ela continuou aumentando, porém muito pouco, a partir desta data. Já o IAF, só atingiu seu máximo no $2^{\circ}$ ano, ao final do ciclo.

Como Chang (1968) destaca, o IAF ótimo não é necessariamente o maior, mas é aquele no qual a fotossíntese esteja ocorrendo de maneira adequada na folhas inferiores, portanto não havendo auto-sombreamento que prejudique a produção de carboidratos.

Dessa forma, o IAF médio da cultura parece estar mais adequado no primeiro ano, que no segundo, mesmo menor, pois considera-se a matéria seca de colmos como o fator mais importante para a produtividade.

Quando se comparam os IAF (Figura 10) e a matéria seca de colmos da última amostragem (Figura 7) da cana crua e da cana queimada, em cada ano, observa-se que, nos dois anos, os valores foram maiores para cana queimada que para cana crua.

Brzesowsky (1985) relacionou o aumento de produtividade com o aumento de IAF, definindo que um pequeno periodo de tempo de crescimento do IAF poderia causar um fechamento rápido do dossel e um melhor aproveitamento da radiação por mais tempo. Para Medina et al. (1970), o fechamento quase completo do dossel ocorre quando o IAF torna-se maior que 4 e a partir do qual, também passa a ocorrer morte de folhas pelo auto-sombreamento.

Levando-se em consideração que o IAF aumenta de cerca de, 0,9 e 1,2, respectivamente em cana crua e cana queimada, aos $150 \mathrm{DAC}$ do $1^{\circ}$ ano, para aproximadamente 7, nos dois tratamentos, aos $213 \mathrm{DAC}$, poder-se-ia considerar, que já nessa data, há fechamento de dossel. Já no $2^{\circ}$ ano, aos 131 DAC, o dossel está fechado. Nesse momento, o IAF nos dois tratamentos atinge 4, enquanto que na data anterior (101 DAC) era de 1,7 em cana crua e 2,4 em cana queimada.

Conjectura-se, então, que os maiores IAF médios da cana queimada, para os dois anos, favoreceram o acúmulo final de matéria seca de colmos, mas o fato do fechamento do dossel ter sido mais rápido, para os dois tratamentos, no $2^{\mathrm{Q}}$ ano, não favoreceu o acúmulo final de materia seca de colmos para os dois tratamentos, embora em cana crua ainda houve influência do ataque de cigarrinhas. 
O comportamento do IAF durante os periodos de amostragem, em cada ano, só apresentou dados significativos aos $241 \mathrm{DAC}$ (22/03) do $2^{\underline{a}}$ ano, em termos de dados absolutos, sem levar em consideração as curvas obtidas. A cana queimada apresentou ligeira vantagem, conforme apresentado na Tabela 14. Quando se verificam as correlações (Tabela 15) para se determinar os fatores influentes no IAF, durante essa data, não se encontram correlações significativas. Portanto, recorre-se à análise das Figuras 22, 38, 46 e 62 para se distinguir a ação dos fatores climáticos sobre os tratamentos. O que se percebe é um certo crescimento em termos de graus-dia, na data (Figura 22) e uma ligeira queda da umidade do ar (Figura 46). Destaca-se então, apenas a umidade do solo de $0-20 \mathrm{~cm}$ de profundidade (Figura 62), aos $241 \mathrm{DAC}$, como diferença entre cana crua e cana queimada, apesar de pequena.

Contudo, essa diferença entre umidades de cana crua e cana queimada não é relevante para causar um menor crescimento em cana crua pela maior umidade do solo. De outra forma, seria se a temperatura já estivesse mais baixa nessa data, o que não ocorre (Figura 65). Até porque, a cigarrinha pode estar causando algum dano à cultura (Figura 15), em termos de IAF, nessa data.

\subsection{Matéria seca e perfil de raízes}

A matéria seca de raizes de cana queimada foi significativamente maior que a de cana crua, somente no $2^{\underline{0}}$ ano, aos 68,167 e 344 DAC (Tabela 6) e a quantidades de raízes foram maiores no $1^{\underline{\rho}}$ ano que no $2^{\underline{0}}$ ano, tanto para cana crua como para cana queimada (Figura 12).

O perfil do sistema radicular (Figuras 13 e 14) demonstrou que as raizes se concentraram mais na superficie e de forma mais marcante na proximidade do eixo da touceira, o que está de acordo com a literatura (Inforzato \& Alvarez, 1957; Sampaio et al., 1987; Ball-Coelho et al., 1992).

As raízes de cana crua distribuíram-se mais superficialmente no $2^{\underline{0}}$ ano, com $70,41 \%$ nos primeiros $40 \mathrm{~cm}$, do que no $1^{\circ}$ ano, com $66,32 \%$. Em cana queimada a 
porcentagem de raízes até $40 \mathrm{~cm}$ foi de $67,69 \%$, no $1^{\circ}$ ano e no $2^{\circ}$ ano de $67,5 \%$ (Tabelas 18 e 19). Inforzato \& Alvarez (1957) encontraram $59 \%$ das raizes nos $30 \mathrm{~cm}$ iniciais de profundidade do solo; em Sampaio et al. (1987), $75 \%$ das raizes encontraram-se até $20 \mathrm{~cm}$ e; Ball-Coelho et al. (1992) observaram que 62,69\% do sistema radicular distribuía-se nos $50 \mathrm{~cm}$.

A comparação estatística dos dados médios de matéria seca de raízes do $1^{9}$ ano de amostragem, distribuídos nas camadas do solo, mostrou diferenças significativas entre cana crua e cana queimada em todas profundidades, em termos de $\mathrm{g} \cdot \mathrm{m}^{-3} \mathrm{e}, \mathrm{em}$ porcentagem de raízes, na última camada, todas com valores maiores para cana crua. No $2^{\circ}$ ano, houve diferenças relevantes na profundidade de $60-80 \mathrm{~cm}$, com dados maiores para cana queimada, em porcentagem e em g. $\mathrm{m}^{-3}$. Essa análise demonstra que, quando se compara cana crua e cana queimada, no $1^{\circ}$ ano não se pode afirmar que a maior porcentagem de raízes de cana queimada na superficie seja significativamente maior que a porcentagem de raízes de cana crua na superficie. No $2^{\circ}$ ano, ocorre o mesmo, ou seja, as raízes de cana crua não estão em maior concentração na superficie que as de cana queimada, do ponto de vista da análise estatística.

Por outro lado, a comparação entre a quantidade de raízes de cana crua e cana queimada, nas 5 profundidades, evidenciou que em cana crua, as raizes aparecem em maior quantidade em todas camadas no $1^{\underline{o}}$ ano, enquanto que no $2^{\underline{Q}}$ ano, a cana crua não sobressaiu-se em relação à cana queimada, até mesmo apresentando quantidades menores de raizes dos 60-80 $\mathrm{cm}$ de profundidade.

Portanto, quando se considera a média de todas as datas de coleta dos dados em cada ciclo de crescimento, nos dois anos de amostragem, por camada de profundidade do solo, pode-se afirmar que a cana crua apresentou uma quantidade maior de raízes no $1^{\circ}$ ano de amostragem.

Aos $68 \mathrm{DAC}$, no $2^{\circ}$ ano, não há correlações entre matéria seca de raízes e os indices biométricos analisados (Tabela 17). Na análise das Figuras 23, 39, 47 e 63, a curva de temperatura de solo de cana crua (Figura 39) mostrou um comportamento diferente da de cana queimada, tendo uma queda aos $68 \mathrm{DAC}$. A curva de acúmulo de 
graus-dia, onde há uma estabilização nesse período (Figura 23), mostra um favorecimento para matéria seca de raízes de cana crua.

É relevante lembrar também, que, nessa data (68 DAC do $2^{\underline{0}}$ ano), o único indice biométrico, daqueles verificados, que apresentou diferença significativa, foi matéria seca de raízes.

Aos $167 \mathrm{DAC}\left(2^{\circ}\right.$ ano), a ocorrência de diferença entre o desenvolvimento de raizes de cana crua e cana queimada é de dificil análise, em termos de influência de parâmetros climatológicos, uma vez que não há correlações. Recorrendo-se aos gráficos comparativos, observa-se que os de temperatura do solo (Figura 39) não demonstram uma grande diferença entre os dois tratamentos, para as 2 profundidades. Nessa data, a temperatura do solo $(5 \mathrm{~cm})$ apresentou seu pico máximo, não havendo uma mudança de tendência, em relação às datas anteriores, para as duas profundidades.

Quanto aos índices biométricos, aos 167 DAC, apenas a correlação com IAF foi significativo positivamente com a cana queimada $(0,9808)$.

Aos 344 DAC, a cana queimada não se correlaciona com nenhum parâmetro ou índice, somente a cana crua correlaciona positivamente $(0,9905)$ com a umidade do solo de $0-20 \mathrm{~cm}$.

A distribuição lateral do sistema radicular é mais marcante na proximidade do eixo da touceira, mas não é tão clara quanto a distribuição das raízes na primeiras profundidades.

A análise dos perfis nos DAC de diferenças significativas, mostra que, aos 68 DAC do $2^{-}$ano (Figura 14 ), as raizes de cana queimada já atingiam camadas mais profundas em uma concentração maior que as da cana crua. Através da observação da Figura 63, verifica-se que a umidade do solo de cana crua ultrapassa a de cana queimada, o que leva a supor que a concentração mais elevada de umidade na superficie não estimula a raiz a crescer até camadas mais profundas. Por isso, talvez, a capacidade de crescer em camadas mais profundas, deve estar relacionada com a disponibilidade hídrica, o que pode ter contribuido para que os valores maiores de raizes na cana queimada, no $2^{\circ}$ ano. Inforzato \& Alvarez (1957) e Camargo (1968) relataram esse fato 
acima exposto, de que a distribuição das raízes no solo é muito afetada pela umidade do mesmo.

Todavia, aos 167 e 344 DAC, a cana crua já apresenta uma distribuição radicular mais semelhante a da cana queimada, embora esta última tenha raizes espalhadas em todo perfil.

A umidade do solo, mesmo apresentando correlação significativa $(0,995)$ com a matéria seca de raízes de cana crua aos 344 DAC, não está mais influenciando sistema radicular da cana crua a distribuir-se superficialmente da mesma forma aos $68 \mathrm{DAC}$, como demonstra a Figura 63, onde não se observa uma diferença tão grande entre a umidade do solo de cana crua e de cana queimada, aos 344 DAC.

\subsection{Dados complementares}

O desempenho da cana crua (CC) e cana queimada (CQ), em termos de matéria seca de colmos apresentou uma relação CC / CQ de $-4,61 \%$, no início do experimento ( $1^{\circ}$ corte), de $6,92 \%$, no final do $1^{\circ}$ ciclo de rebrota ( $2^{\circ}$ corte) e, de 28,95 $\%$ no final do $2^{2}$ ciclo de rebrota ( $3^{\circ}$ corte). Campos \& Marconato (1994) encontraram uma relação CQ / CC de $-2,2 \%$, para o primeiro corte da variedade SP 70-1143 (Figura 11).

Vale ressaltar, que os dados apresentados nesse trabalho indicam a necessidade de estudos que dêem continuidade à avaliação das diferenças entre cana crua e cana queimada, no decorrer do ciclo produtivo de sua soqueira. Essa avaliação fornecerá maiores subsídios para possiveis modelos matemáticos que expliquem a influência dos elementos meteorológicos principais, de forma integrada, sobre o desempenho da cana-de-açúcar após sua rebrota em diferentes formas de colheita. 


\section{CONCLUSÕes}

Face ao resultados obtidos neste estudo, conclui-se que:

1. O desenvolvimento no primeiro ciclo de crescimento é semelhante para cana crua e cana queimada

2. No início do segundo ciclo de crescimento ocorre maior desenvolvimento em cana crua, enquanto que no final, o desenvolvimento é maior em cana queimada.

3. O perfilhamento da cana crua não apresenta diferenças significativas que confirmem a influência negativa da palha na rebrota.

4. As raizes de cana crua, aparecem em maior quantidade em todas camadas no primeiro ano.

5. De um modo geral, os fatores climatológicos, isoladamente, não provocam mudanças na comparação entre os indices biométricos de cana crua e de cana queimada, em seus ciclos de crescimento.

6. As diferenças de desenvolvimento expressas na curva de crescimento do primeiro para o segundo ano são devidas aos fatores climatológicos, tanto para cana crua como cana queimada. 


\section{REFERÊYCIAS BIBLIOGRÁFICAS}

ABRAMO FILHO, J.; MATSUOKA, S.; SPERANDIO, M.L.; RODRIGUES, R.C.D.; MARCHETTI, L.L. Resíduo de colheita mecanizada de cana crua. Álcool \& Açúcar, n.67, p.23-25, abr./maio 1993.

ALFONSI, R.R.; PEDRO JÚNIOR, M.J.; BRUNINI, O.; BARBIERI, V. Variedades de cana-de-açúcar. In: PARANHOS, S.B. (Coord.) Cana-de-açúcar: cultivo e utilização. Campinas: Fundação Cargill, 1987. v.1, cap. 1, p.52-55.

ALMEIDA, M. Caracterização organográfica e bioquímica de dez cultivares de canade-açúcar (Saccharum spp.). Piracicaba, 1986. 83p. Dissertação (Mestrado) Escola Superior de Agricultura "Luiz de Queiroz", Universidade de São Paulo.

ASANA, R.D. Growth analysis of the sugar cane crop in North Bihar (India). Annals of Botany, v. 14, p.465-486, 1950.

BACCHI, O.O.S.; SOUZA, J.A.G.C. Minimum threshold temperature for sugar cane growth. In: CONGRESS OF THE INTERNATIONAL SOCIETY OF SUGAR CANE TECHNOLOGISTS, São Paulo, 1977 Proceedings. São Paulo, 1978, v.2, p. 1733-1741. 
BALL-COELHO, B.; SAMPAIO, E.V.S.B.; TIESSEN, H.; STEWART, J.W.B. Root dynamic in plant ratoon crops of sugar cane. Plant and Soil, v.142, p.297-305, 1992.

BARBIERI, V.; BACCHI, O.O.S.; VILLA NOVA, N.A. Análise do fator temperatura média do ar no desenvolvimento da cana-de-açúcar. In: CONGRESSO NACIONAL DA SOCIEDADE DOS TÉCNICOS AÇUCAREIROS DO BRASIL, 2, Rio de Janeiro, 1981. Anais. Rio de Janeiro: STAB, 1981. v.3/4, p.512-522.

BARBIERI, V. Condicionamento climático da produtividade potencial da cana-deaçúcar (Saccharum spp.): um modelo matemático-fisiológico de estimativa. Piracicaba, 1993. 142p. Tese (Doutorado) - Escola Superior de Agricultura "Luiz de Queiroz", Universidade de São Paulo.

BARBOSA, V. Cultivo de soqueira, adubação e reforma de canaviais sob sistema de cana crua. In: SEMANA DA CANA-DE-AÇÚCAR DE PIRACICABA, 2., Piracicaba, 1997. Resumos. Piracicaba: FEALQ, 1997. p.52-54.

BAVER, L.D. BRODIE, H. TANIMOTO, T. TROUSE, A.C. New approaches to the study of cane root system. In: CONGRESS OF THE INTERNATIONAL SOCIETY OF SUGAR CANE TECHNOLOGISTS, São Paulo, 1962. Proceedings. São Paulo, v.11, 1962. p.248-253.

BLACKBURN, f. Sugarcane. New York: Longman, 1984. 414p.

BRINHOLI, O. Resistência ao frio de algumas variedades de cana-de-açúcar (Saccharum spp.). Piracicaba, 1972. 88p. Tese (Doutorado) - Escola Superior de Agricultura "Luiz de Queiroz", Universidade de São Paulo. 
BRZESOWSKY, W.J. Factor affecting sugar cane. 1: Cane growing. Agriculture International, World Crops, v.37, n.7, p.256-260, Nov.1985.

BRZESOWSKY, W.J. Factor affecting sugar cane. 2: Crop growth rate. Agriculture International, World Crops, v.38, n.1, p.30-35, Jan./Marc. 1986.

CAMARGO, P.N. Fisiologia da cana-de-açúcar. Piracicaba: ESALQ, 1968. 38p.

CAMPOS, M.S.; MARCONATO, A. Sistema cana crua x cana queimada. CLAAS 2000. STAB, v.12, n.13, 1994. p.10-17, jan/fev.

CARVALHO, L.C.C. Mercado nacional e internacional do açúcar e do álcool. In: SEMANA DA CANA-DE-AÇÚCAR DE PIRACICABA, 2., Piracicaba, 1997. Resumos. Piracicaba: FEALQ, 1997. p.16-28.

CASAGRANDE, A.A. Tópicos de morfologia e fisiologia da cana-de-açúcar. Jaboticabal: Funep, 1991. 157p.

CHANG, J. Climate and agriculture: an ecological survey. Chicago: Aldine, 1968. $304 p$.

CHRISTOFFOLETI, P.J. Aspectos físiológicos da brotação, perfilhamento e florescimento da cana-de-açúcar. Piracicaba: ESALQ, 1986. 80p.

CHURCHWARD, E.H.; POULSEN, N.J. Review of harvesting developments. In: CONGRESS OF THE AUSTRALIAN SOCIETY OF SUGAR CANE TECHNOLOGISTS, Sydney, 1988. Proceedings. Sydney, 1988. p.1-6. 
DIB NUNES JR., M.S Variedades de cana-de-açúcar. In: PARANHOS, S.B. (Coord.) Cana-de-açúcar: cultivo e utilização. Campinas: Fundação Cargill, 1987. v.2, cap. 2, p. 187-259.

DILLEWIJN, C.N. Botanique de la cana a sucre. Wageningen: Veenman \& Zonen, 1960. $591 \mathrm{p}$.

FAUCONIER, R.; BASSEREAU, D. La caña de azúcar. Barcelona: Blume, 1975. $433 p$.

FERNANDES, J. A subsolagem no controle da compactação do solo na cana-soca (Saccharum sp) variedade CB 41-76 e seus efeitos no rendimento agrícola e no sistema radicular. Piracicaba, 1979 Dissertação (Mestrado) - Escola Superior de Agricultura "Luiz de Queiroz", Universidade de São Paulo.

FURLANI NETO, V.L. Colheita mecanizada da cana-de-açúcar STAB, v.12, n.13, . p.8-9, jan/fev. 1994.

FURLANI NETO, V.L. Desempenho operacional de colhedora de cana-de-açúcar (Saccharum spp.) em canaviais com e sem queima. Piracicaba, 1995. 112p. Tese (Doutorado) - Escola Superior de Agricultura "Luiz de Queiroz", Universidade de São Paulo.

GASCHO, G.J.; SHIH, S.F. Sugarcane. TEERE, I.D.; PEET, M.M. Crop - Water relations. New York: Interscience, 1983. p.445-79.

GLASZIOU, K.T.; BULL, T.A.; HATCH, M.D.; WHITEMAN, P.C. Physiology of sugar-cane. VII. Effects of temperature, photoperiod duration, and diurnal and seasonal temperature changes on growth and ripening. Australian Journal of Biological Sciences, v. 18, p. 53-66, 1965. 
GOSNELL, J.M. Some effects of increasing age in sugarcane growth. In: CONGRESS OF THE INTERNATIONAL SOCIETY OF SUGAR CANE TECHNOLOGISTS, Taiwan, 1968. Proceedings. Amsterdan, v.13, 1969. p.499-513.

GOULART, M.P. Legislação ambiental e queimada de cana In: In: SEMANA DA CANA-DE-AÇÚCAR DE PIRACICABA, 2., Piracicaba, 1997. Resumos. Piracicaba: FEALQ, 1997. p.61-66.

HOFFMANN, R.; VIEIRA, F. Análise de Regressão: uma introdução à econometria. São Paulo: Hucitec, 1983.

HUMBERT, R.P. The growing of sugar cane. Amsterdan: Elsevir, 1968. 719 p.

INFORZATO, R.; ALVAREZ, R. Distribuição do sistema radicular da cana-de-açúcar va. 290 , em solo tipo terra-roxa legítima. Bragantia, v.16, n.1, p.1-13, 1957.

INMAN-BAMBER, N.G.; DE JAGER, J.M. The reaction of two varieties of sugarcane to water stress. Field Crop Research, v. 14, p.15-28, 1986.

INSTITUTO DO AÇÚCAR E DO ÁLCOOL Cultura da cana-de-açúcar: manual de orientação. Piracicaba: PLANALSUCAR, 1980. 80p.

INSTITUTO DO AÇÚCAR E DO ÁLCOOL Cultura da cana-de-açúcar: manual de orientação. Piracicaba: PLANALSUCAR, Coordenação Regional Sul, 1986. 56p.

IRVINE, J.E. Relations of photosynthetic rates and leaf and canopy characters to sugarcane yield. Crop Science, v.15, p. 671-676, 1975. 
IRVINE, J.E. Sugarcane. In: SYMPOSIUM ON POTENTIAL PRODUCTIVITY OF FIELD CROPS UNDER DIFFERENT ENVIROMENTS, Los Baños, 1983. Proceedings Los Baños: IRRI, 1983. p.361-381.

IRVINE, J.E.; BENDA, T.A. Sugarcane spacing. I. Historical and theoretical aspects. In: CONGRESS OF THE INTERNATIONAL SOCIETY OF SUGAR CANE TECHNOLOGISTS, 17. Manila, 1980. Proceedings. Manila: ISSCT, 1980. p.350355 .

KORNDORFER, G.H. Crescimento e distribuição do sistema radicular de cana-deaçúcar em solo LVA. Coopersucar, 1989. p.47-89. (Boletim técnico n. 47)

KOPKE, V. Methods for studying root growth. In: SYMPOSIUM ON THE SOIL/ROOT SYSTEM IN RELATION TO BRAZIL AGRICULTURE, Londrina, 1980. Proceedings. Londrina: Fundação Instituto Agronômico do Paraná, 1981. p.130.

MACHADO, E.C. Fisiologia de produção de cana-de-açúcar In: PARANHOS, S.B. (Coord.) Cana-de-açúcar: cultivo e utilização. Campinas: Fundação Cargill, 1987. v.1, cap. 1, p. 56-87.

MACHADO, E.C.; PEREIRA, A.R.; CAMARGO, M.B.P.; FAHL, J.I.; Relações radiométricas de uma cultura de cana-de-açúcar. Bragantia, v.44, n.1, p.229-38, 1985

MACHADO, E.C.; PEREIRA, A.R.; FAHL, J.I.; ARRUDA, H.V.; CIONE, J. Índices biométricos de duas variedades de cana-de-açúcar. Pesquisa Agropecuária Brasileira, v.17, n.9, p.1323-1329, set. 1982. 
MAGRO, J.A. Sistema cana crua: perspectivas de viabilidade In: SEMANA DA CANA-DE-AÇÚCAR DE PIRACICABA, 3., Piracicaba, 1998. Anais. Piracicaba: STAB, 1998. p.31-32.

MANIERO, M.A. Aplicação do método de graus dia em cana-de-açúcar (Saccharum spp.) Piracicaba, 1980. 76 p. Dissertação (Mestrado) - Escola Superior de Agricultura "Luiz de Queiroz", Universidade de São Paulo.

MEDINA, E; SAN JOSE, J.J;; SEQUEIRA, P.E. Análisis de la produtividad en caña de azúcar. III. Respiración en la oscuridad de hojas y tallos de cinco variedades de caña de azúcar y pérdidas nocturnas de materia seca. Turrialba, v.20, n.2, p.302$306,1970$.

McLEAN, F.G.; McDAVID, C.E.; SINGH, Y. Preliminary results of net assimilation rate studies in sugarcane. In: CONGRESS OF THE INTERNATIONAL SOCIETY OF SUGAR CANE TECHNOLOGISTS, Taiwan, 1968. Proceedings. Amsterdan, v.13, 1969. p.849-58.

MONGELARD, J.C.; MIMURA, L. Growth studies on the sugarcane plant. I. Effects of temperature Crop Science, v.11, p.795-800, Nov./Dec. 1971.

OLIVEIRA, O.C.; URQUIAGA, S.S; BODDEY, R.M. La quema de la caña: efectos a largo plazo. International Sugar Journal, v.97, p.384-387, 1985.

OLIVEIRA, P. Ajustamento de alguns modelos exponenciais a dados de crescimento da cana-de-açúcar. Piracicaba, 1992. 72 p. Dissertação (Mestrado) - Escola Superior de Agricultura "Luiz de Queiroz", Universidade de São Paulo. 
PEARSON, C.H.O. The conception of farming on sub-tropical soil, with the use of crop by product, trash as a mean to improve yields. In: CONGRESS OF THE INTERNATIONAL SOCIETY OF SUGAR CANE TECHNOLOGISTS, 10, Hawaii, 1959. Proceedings. Amsterdan, 1960. p.579-588.

PEREIRA, A.R.; MACHADO, E.C. Análise quantitativa de crescimento de comunidades vegetais. Campinas: Boletim do Instituto Agronômico de Campinas, 1987. n. 114,33 p.

PERIN, M.A.F. Estudo fisiológico comparado do desenvolvimento e efeito do ethephon na qualidade tecnológica de quatro variedades de cana-de-açúcar (Saccharum spp.). Piracicaba, 1996. 110p. Dissertação (Mestrado) - Escola Superior de Agricultura "Luiz de Queiroz", Universidade de São Paulo.

PRADO, A.P. A. Perfilhamento e produção de cana-de-açúcar (Sacharum spp.) em função da densidade de plantio. Piracicaba, 1988. 69p. Dissertação (Mestrado) Escola Superior de Agricultura "Luiz de Queiroz", Universidade de São Paulo.

RIPOLI, T.C.C.; PARANHOS, S.B. Sistemas de colheita. In: PARANHOS, S.B. (Coord.) Cana-de-açúcar: cultivo e utilização. Campinas: Fundação Cargill, 1987. v.2, cap. 5, p.519-597.

RIPOLI, T.C.; MOLINA JR., W.F.; STUPIELLO; J.P; NOGUEIRA, M.C.; SACCOMANO, J.B. Potencial energético de resíduos de cosecha de la caña verde. STAB, v.10, n.1, p.22-28, 1991.

RIPOLI, T.C.C.; VILLANOVA, N.A. Colheita manual vs. mecânica de cana-de-açúcar: novos desafios STAB, v.11, n.1, p.28-31, set./out., 1992. 
ROCHA, A.M.C. Emergência, perfilhamento e produção de colmos da cana-de-açúcar (Saccharum spp) em função das épocas de plantio no Estado de São Paulo. Piracicaba, 1984. 154p. Dissertação (Mestrado) - Escola Superior de Agricultura "Luiz de Queiroz", Universidade de São Paulo.

ROSTRON, H. Radiant energy interception, root growth, dry matter production and apparent yield potential of two sugar-cane varieties. CONGRESS OF THE INTERNATIONAL SOCIETY OF SUGAR CANE TECHNOLOGISTS, Durban, 1974. Proceeding. Durban, 1974. v.15p., 1001-1010.

ROZEFF, N. Biomasa y quema de la caña de azúcar: un esquema empírico para el Valle del Bajo Río Grande de Tejas. International Sugar Journal, v.97, p.184-187, 1995a.

ROZEFF, N. Harvest comparisons of green and burned sugarcane in Texas. International Sugar Journal, v.97, p.501-506, 1995b.

SALISBURY, F.B.; ROSS, C.W. Plant physiology 4.ed. Belmont: Wadsworth Publ., 1992. $682 \mathrm{p}$.

SAMPAIO, E.V.S.B.; SALCEDO, J.H. CAVALCANTI, F.J.A. Dinâmica de nutrientes em cana-de-açúcar. III. Conteúdo de nutrientes e distribuição do sistema radicular no solo. Pesquisa Agropecuária Brasileira, v.22, , p.425-431, set. 1987.

SAN JOSE, J.J.; MEDINA, E. Análisis de la productividad de caña de azúcar. I. crescimiento, desarrollo de la superficie foliar e contenido de clorofila de caña de azúcar 'PR 980’. Turrialba, v.20, n.2, p. 143-148, 1970. 
SILVA, G.M.A. Cana crua x cana queimada. Restrições técnicas e implicações sociais e econômicas. In: SEMANA DA CANA-DE-AÇÚCAR DE PIRACICABA, 2., Piracicaba, 1997. Resumos. Piracicaba: FEALQ, 1997. p.55-57.

SILVEIRA, J.A.G.; Integração entre assimilação de nitrogênio e o crescimento de canade-açúcar (Sacharum spp.) cultivada em condições de campo. Piracicaba, 1985. 152p. Tese (Doutorado) - Escola Superior de Agricultura "Luiz de Queiroz", Universidade de São Paulo.

SOARES, G.C.; BALBO, L.; PINTO, A.R. Colheita mecânica de cana-picada STAB, v.12, n.13, p.18-20, jan./fev. 1994.

STUPIELLO, J.P. A cana-de-açúcar como matéria prima In: PARANHOS, S.B. (Coord.) Cana-de-açúcar: cultivo e utilização. Campinas: Fundação Cargill, 1987. v. 2 , cap. 7 , p. $759-804$.

TERUEL, D.A. Modelagem do índice de área foliar da cana-de-açúcar em diferentes regimes hídricos. Piracicaba, 1995. 93p. Dissertação (Mestrado)-Escola Superior de Agricultura "Luiz de Queiroz", Universidade de São Paulo.

THOMPSON, G.D. The production of trash and it effects as a mulch on the soil and sugar cane nutrition. In: CONGRESS SOUTH AFRICAN SUGAR TECNOLOGY ASSOCIATION, 40., Mount Edegecombe, 1969. Proceedings. Mount Edegecombe, 1969. p.1-10.

THOMPSON, G.D.; DU TOIT, J.L. The effects of row spacing on sugar cane in Natal. CONGRESS OF THE INTERNATIONAL SOCIETY OF SUGAR CANE TECHNOLOGISTS Proceeding. v.12, p.103-112, 1965. 
WOOD, R.A. The influence of trash on nitrogen mineralization - immobilization relatioship in sugar belt soils. In: CONGRESS SOUTH AFRICAN SUGAR TECNOLOGY ASSOCIATION, 40., Mount Edegecombe, 1969. Proceedings. Mount Edegecombe, 1969. p.253-262.

YOON, C.N. Growth studies on sugarcane. I. Dry matter production. The Malaysian Agricultural Journal, v.48, n.2, p.47-59, 1971.

ZULALF, W.E; CARPORALI, S.A.; VIDEIRA, R.M. Cálculo preliminar de energia liberada anualmente na queima dos canaviais brasileiros. In: SIMPÓSIO SOBRE QUEIMA DE PALHA DE CANAVIAIS, 2, Araraquara, 1985. p.1-7. 